\title{
Schoolverlaters tussen onderwijs en arbeidsmarkt 2001. Statistische Bijlage
}

Citation for published version (APA):

Researchcentrum voor Onderwijs en Arbeidsmarkt, ROA. (2002). Schoolverlaters tussen onderwijs en arbeidsmarkt 2001. Statistische Bijlage. ROA. ROA Reports No. 008B https://doi.org/10.26481/umarep.2002008B

Document status and date:

Published: 01/01/2002

DOI:

10.26481/umarep.2002008B

Document Version:

Publisher's PDF, also known as Version of record

\section{Please check the document version of this publication:}

- A submitted manuscript is the version of the article upon submission and before peer-review. There can be important differences between the submitted version and the official published version of record.

People interested in the research are advised to contact the author for the final version of the publication, or visit the DOI to the publisher's website.

- The final author version and the galley proof are versions of the publication after peer review.

- The final published version features the final layout of the paper including the volume, issue and page numbers.

Link to publication

\footnotetext{
General rights rights.

- You may freely distribute the URL identifying the publication in the public portal. please follow below link for the End User Agreement:

www.umlib.nl/taverne-license

Take down policy

If you believe that this document breaches copyright please contact us at:

repository@maastrichtuniversity.nl

providing details and we will investigate your claim.
}

Copyright and moral rights for the publications made accessible in the public portal are retained by the authors and/or other copyright owners and it is a condition of accessing publications that users recognise and abide by the legal requirements associated with these

- Users may download and print one copy of any publication from the public portal for the purpose of private study or research.

- You may not further distribute the material or use it for any profit-making activity or commercial gain

If the publication is distributed under the terms of Article $25 \mathrm{fa}$ of the Dutch Copyright Act, indicated by the "Taverne" license above, 


\section{Statistische Bijlage}

Schoolverlaters tussen onderwijs en arbeidsmarkt 2001

ROA-R-2002/8B

Researchcentrum voor Onderwijs en Arbeidsmarkt

Faculteit der Economische Wetenschappen en Bedrijfskunde

Universiteit Maastricht

Maastricht, juli 2002 
Niets uit deze uitgave mag worden verveelvoudigd en/of openbaar gemaakt door middel van druk, fotokopie, microfilm, of op welke wijze ook, zonder voorafgaande schriftelijke toestemming van de directeur van het Researchcentrum voor Onderwijs en Arbeidsmarkt. In geval van overname van het datamateriaal moet telkens duidelijk als bron worden vermeld: "Researchcentrum voor Onderwijs en Arbeidsmarkt" of "ROA". Van publicaties waarin gebruik wordt gemaakt van gegevens uit deze Statistische Bijlage ontvangen wij gaarne een exemplaar.

Hoewel de grootst mogelijke zorg is besteed aan de inhoud van dit rapport, kan het ROA in generlei opzicht verantwoordelijkheid op zich nemen voor eventuele onvolledigheden of onjuistheden.

ISBN 90-5321-336-8

Sec02.072 


\section{Inhoud}

Bladzijde

Voorwoord

\section{A. Tabellen per opleidingssector}

1 Bestemming van schoolverlaters

A1.1 De uitstroom van schoolverlaters verbijzonderd naar geslacht, etniciteit en gemiddelde leeftijd op moment van enquête

A1.2 Vooropleiding van schoolverlaters

A1.3 Bestemming van schoolverlaters

A1.4 Gevolgde opleiding opnieuw kiezen?

\section{Doorstroom naar vervolgonderwijs}

A2.1 Doorstroom van schoolverlaters naar vervolgonderwijs

A2.2 Belangrijkste opleidingen van schoolverlaters die een voltijd vervolgopleiding zijn gaan volgen

A2.3 Oordeel van schoolverlaters over de aansluiting van de afgesloten opleiding met de voltijd vervolgopleiding

A2.4 Doorstroom van schoolverlaters naar de beroepsbegeleidende leerweg

3 Intrede op de arbeidsmarkt

A3.1 Werkloosheid en gemiddelde intredewerkloosheid van schoolverlaters die zich aanbieden op de arbeidsmarkt

A3.2 Aard van het dienstverband van werkende schoolverlaters

A3.3 Percentage werkende schoolverlaters met een flexibele aanstelling 24

$\begin{array}{lll}\text { A3.4 Wijze van verkrijgen van een baan } & 26\end{array}$

A3.5 Belangrijkste bedrijfsgroepen waarin schoolverlaters werkzaam zijn $\quad 28$

A3.6 Belangrijkste beroepsgroepen waarin schoolverlaters werkzaam zijn 33

A3.7 Grootte van de organisatie waarin schoolverlaters werkzaam zijn 38

A3.8 Beloning van werkende schoolverlaters $\quad 40$

A3.9 Vereist opleidingsniveau voor de huidige functie volgens de werkgever 42

A3.10 Vereiste opleidingsrichting voor de huidige functie volgens de werkgever 43

A3.11 Gewenste en feitelijke wekelijkse arbeidsduur van werkende schoolverlaters $\quad 44$

A3.12 Oordeel van de werkende schoolverlaters over de aansluiting tussen de afgesloten opleiding en de huidige functie

A3.13 Percentage werkende schoolverlaters dat op zoek is naar een andere baan

A3.14 Deelname aan een cursus of bedrijfsopleiding door werkende schoolverlaters schoolverlaters deelnemen

4 Kernindicatoren

A4.1 Enkele kernindicatoren 


\section{B. Tabellen per opleidingsrichting}

1 Bestemming van schoolverlaters

B1.1 De uitstroom van schoolverlaters verbijzonderd naar geslacht, etniciteit en gemiddelde leeftijd op moment van enquête

B1.2 Vooropleiding van schoolverlaters

B1.3 Bestemming van schoolverlaters

B1.4 Gevolgde opleiding opnieuw kiezen?

\section{Doorstroom naar vervolgonderwijs}

B2.1 Doorstroom van schoolverlaters naar vervolgonderwijs

B2.2 Belangrijkste opleidingen van schoolverlaters die een voltijd vervolgopleiding zijn gaan volgen

B2.3 Oordeel van schoolverlaters over de aansluiting van de afgesloten opleiding met de voltijd vervolgopleiding

B2.4 Doorstroom van schoolverlaters naar de beroepsbegeleidende leerweg

\section{Intrede op de arbeidsmarkt}

B3.1 Werkloosheid en gemiddelde intredewerkloosheid van schoolverlaters die zich aanbieden op de arbeidsmarkt

B3.2 Aard van het dienstverband van werkende schoolverlaters 95

B3.3 Percentage werkende schoolverlaters met een flexibele aanstelling 99

B3.4 Wijze van verkrijgen van een baan 101

B3.5 Belangrijkste bedrijfsgroepen waarin schoolverlaters werkzaam zijn 105

B3.6 Belangrijkste beroepsgroepen waarin schoolverlaters werkzaam zijn 117

B3.7 Grootte van de organisatie waarin schoolverlaters werkzaam zijn 129

B3.8 Beloning van werkende schoolverlaters 131

B3.9 Vereist opleidingsniveau voor de huidige functie volgens de werkgever 133

B3.10 Vereiste opleidingsrichting voor de huidige functie volgens de werkgever $\quad 135$

B3.11 Gewenste en feitelijke wekelijkse arbeidsduur van werkende schoolverlaters $\quad 138$

B3.12 Oordeel van de werkende schoolverlaters over de aansluiting tussen de afgesloten opleiding en de huidige functie

B3.13 Percentage werkende schoolverlaters dat op zoek is naar een andere baan

B3.14 Deelname aan een cursus of bedrijfsopleiding door werkende schoolverlaters

B3.15 Belangrijkste cursussen of bedrijfsopleidingen waaraan werkende schoolverlaters deelnemen

4 Kernindicatoren

B4.1 Enkele kernindicatoren 


\section{Respons}

C.1 Ongewogen aantal respondenten verbijzonderd naar bestemming per opleidingssector

C.2 Naar landelijke populatie gewogen aantal schoolverlaters verbijzonderd naar bestemming per opleidingssector

C.3 Responspercentage per opleidingssector

C.4 Ongewogen aantal respondenten verbijzonderd naar bestemming per opleidingsrichting

C.5 Naar landelijke populatie gewogen aantal schoolverlaters verbijzonderd naar bestemming per opleidingsrichting

C.6 Responspercentage per opleidingsrichting

\section{Opleidingsindeling}

Overzicht van opleidingen per opleidingssector 

Tabellenoverzicht Statistische Bijlage

Schoolverlaters tussen Onderwijs en Arbeidsmarkt

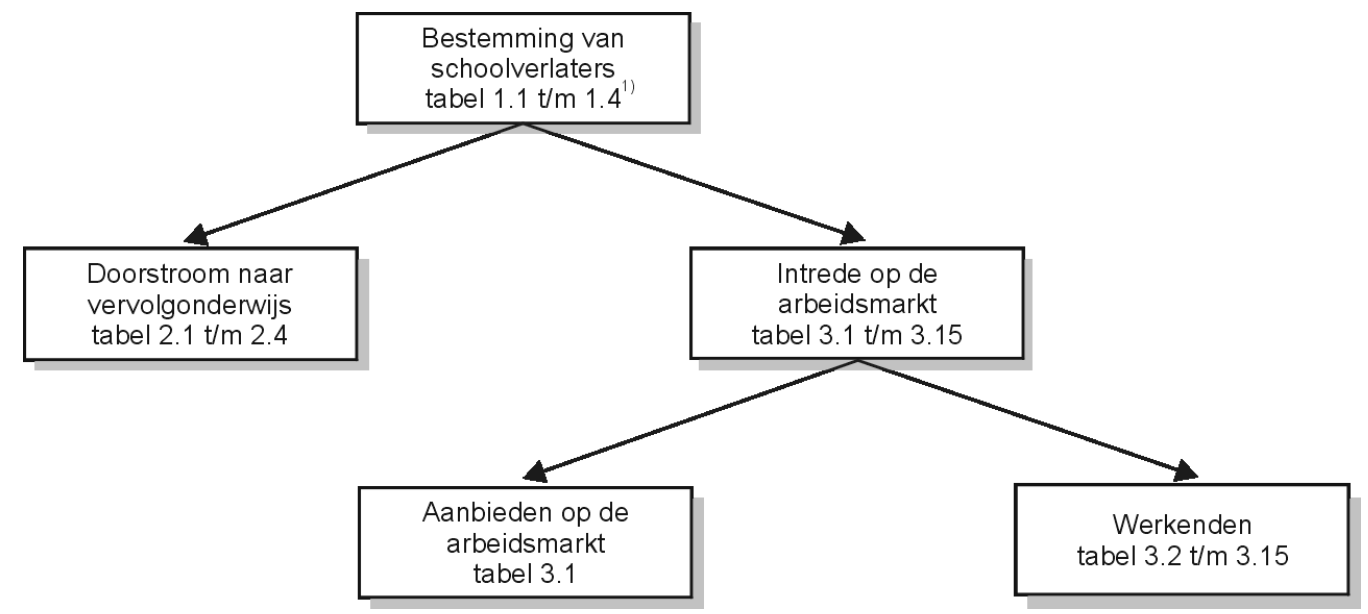

1) Tabelnummers gelden voor het A-deel en het B-deel van de statistische bijlage. Het A-deel bestaat uit tabellen naar opleidingssector, het B-deel uit tabellen naar opleidingsrichting. 



\section{Voorwoord}

In deze Statistische Bijlage bij het rapport Schoolverlaters tussen onderwijs en arbeidsmarkt 2001 wordt een overzicht gegeven van de belangrijkste resultaten van de schoolverlatersonderzoeken die door het Researchcentrum voor Onderwijs en Arbeidsmarkt (ROA) in het najaar van 2001 zijn gehouden onder schoolverlaters en afgestudeerden van het school- of studiejaar 1999/2000. De gegevens bestrijken de volle breedte van het Nederlandse onderwijssysteem en hebben betrekking op de situatie van schoolverlaters en afgestudeerden ongeveer anderhalf jaar na het voltooien van de opleiding. Allereerst betreft het de enquête Registratie van Uitstroom en Bestemming van Schoolverlaters (RUBS). Deze enquête is gericht op schoolverlaters van het algemeen voortgezet onderwijs (AVO), het voorbereidend beroepsonderwijs (VBO) en de beroepsopleidende (BOL) en beroepsbegeleidende leerweg (BBL) van het secundair beroepsonderwijs. Daarnaast zijn gegevens opgenomen afkomstig uit de HBOMonitor en WO-Monitor. Dit zijn volledig vergelijkbare enquêtes gericht op afgestudeerden van het hoger onderwijs en ze worden uitgevoerd onder toezicht van respectievelijk de HBO-Raad en de Vereniging van Samenwerkende Nederlandse Universiteiten (VSNU).

Voor alle getoonde gegevens geldt dat het gaat om gediplomeerde schoolverlaters en afgestudeerden. Bovendien betreft het alleen de uitstroom van voltijdopleidingen. Een uitzondering hierop wordt gevormd door de gediplomeerde schoolverlaters van de BBL die leren en werken combineren.

In deel A worden de belangrijkste gegevens per onderwijssoort en opleidingssector (bijvoorbeeld BOL niveau 1/2 techniek, HBO economie, WO gezondheidszorg) gepresenteerd. Binnen het secundair beroepsonderwijs zijn daarbij de niveaus 1 en 2 (assistent beroepsbeoefenaar (AB) en beginnend beroepsbeoefenaar (BB)) aan de ene kant en de niveaus 3 en 4 (zelfstandig beroepsbeoefenaar (ZB) en (midden)kaderfunctionaris $((\mathrm{M}) \mathrm{KF})$ of specialist) aan de andere kant samengenomen. Deel B geeft vervolgens voor de opleidingsrichtingen van VBO, BOL en BBL een gedetailleerder overzicht ${ }^{1}$. Daarbij worden alleen voor die opleidingsrichtingen cijfers gepresenteerd waarvoor de resultaten voldoende betrouwbaar worden geacht. Daartoe is een ondergrens van 15 respondenten gehanteerd. Bij tabellen die betrekking hebben op de beroepsbevolking of op werkenden is de ondergrens gesteld op 15 respondenten die tot de beroepsbevolking behoren. Bij tabellen die betrekking hebben op vervolgopleidingen of cursussen is de ondergrens gelegd bij minimaal 15 respondenten die een vervolgopleiding respectievelijk cursus hebben gevolgd. Overigens kunnen de gepresenteerde percentages bij sommige tabellen - vanwege ontbrekende waarnemingen - op een geringer aantal respondenten zijn gebaseerd. Hiermee dient bij de interpretatie van de gegevens rekening te worden gehouden.

Binnen de delen A en B is een onderverdeling gemaakt. Het eerste onderdeel van beide delen heeft betrekking op de bestemming van schoolverlaters: werken, leren of een combinatie van werken en leren via de BBL. Het tweede onderdeel gaat dieper in op degenen die verder leren, terwijl het derde onderdeel de intrede op de arbeidsmarkt nader beschrijft. De groep die werken en leren combineert via de BBL komt zowel in het tweede onderdeel ('doorstroom naar vervolgonderwijs') als in het derde onderdeel ('intrede op de arbeidsmarkt') aan de orde. Ten slotte bevatten de delen A en $B$ een samenvattende tabel met daarin de belangrijkste kernindicatoren.

1. Voor een gedetailleerd beeld van de resultaten voor het HBO wordt verwezen naar het onlangs verschenen Statistisch supplement van de HBO-Monitor 2001, uitgegeven door de HBO-Raad. Uitvoeriger resultaten van de WO-Monitor 2001 zullen later dit jaar bekend worden gemaakt door de VSNU. 
Deel C geeft enkele achtergrondcijfers van de enquêtes: ongewogen en opgehoogde aantallen schoolverlaters, alsmede de responspercentages. In deel D is tot slot een overzicht opgenomen van de in de enquêtes opgenomen opleidingen per sector. 
A. Tabellen per opleidingssector 



\section{Inhoud}

1 Bestemming van schoolverlaters

A1.1 De uitstroom van schoolverlaters verbijzonderd naar geslacht, etniciteit en gemiddelde leeftijd op moment van enquête

A1.2 Vooropleiding van schoolverlaters

A1.3 Bestemming van schoolverlaters

A1.4 Gevolgde opleiding opnieuw kiezen?

\section{Doorstroom naar vervolgonderwijs}

A2.1 Doorstroom van schoolverlaters naar vervolgonderwijs

A2.2 Belangrijkste opleidingen van schoolverlaters die een voltijd vervolgopleiding zijn gaan volgen

A2.3 Oordeel van schoolverlaters over de aansluiting van de afgesloten opleiding met de voltijd vervolgopleiding

A2.4 Doorstroom van schoolverlaters naar de beroepsbegeleidende leerweg

3 Intrede op de arbeidsmarkt

A3.1 Werkloosheid en gemiddelde intredewerkloosheid van schoolverlaters die zich aanbieden op de arbeidsmarkt

A3.2 Aard van het dienstverband van werkende schoolverlaters

A3.3 Percentage werkende schoolverlaters met een flexibele aanstelling

A3.4 Wijze van verkrijgen van een baan

A3.5 Belangrijkste bedrijfsgroepen waarin schoolverlaters werkzaam zijn

A3.6 Belangrijkste beroepsgroepen waarin schoolverlaters werkzaam zijn

A3.7 Grootte van de organisatie waarin schoolverlaters werkzaam zijn

A3.8 Beloning van werkende schoolverlaters

A3.9 Vereist opleidingsniveau voor de huidige functie volgens de werkgever

A3.10 Vereiste opleidingsrichting voor de huidige functie volgens de werkgever

A3.11 Gewenste en feitelijke wekelijkse arbeidsduur van werkende schoolverlaters

A3.12 Oordeel van de werkende schoolverlaters over de aansluiting tussen de afgesloten opleiding en de huidige functie

A3.13 Percentage werkende schoolverlaters dat op zoek is naar een andere baan

A3.14 Deelname aan een cursus of bedrijfsopleiding door werkende schoolverlaters

A3.15 Belangrijkste cursussen of bedrijfsopleidingen waaraan werkende schoolverlaters deelnemen

4 Kernindicatoren

A4.1 Enkele kernindicatoren 
Tabel A1.1

De uitstroom van schoolverlaters verbijzonderd naar geslacht, etniciteit en gemiddelde leeftijd op moment van enquête

\begin{tabular}{|c|c|c|c|}
\hline Opleidingssector & $\begin{array}{r}\text { vrouw } \\
\%\end{array}$ & $\begin{array}{r}\text { allochtoon } \\
\%\end{array}$ & $\begin{array}{r}\text { leeftijd } \\
\text { gem. }\end{array}$ \\
\hline AVO & 53 & 10 & 18,2 \\
\hline MAVO & 52 & 11 & 17,3 \\
\hline HAVO & 55 & 9 & 18,6 \\
\hline VWO & 52 & 9 & 19,3 \\
\hline VBO & 50 & 13 & 17,4 \\
\hline IVBO & 45 & 9 & 17,6 \\
\hline Landbouw & 60 & 5 & 17,4 \\
\hline Techniek & 5 & 9 & 17,4 \\
\hline Economie & 62 & 32 & 17,5 \\
\hline Gezondheidszorg & 99 & 8 & 17,2 \\
\hline BOL niveau $1 / 2$ & 57 & 21 & 20,4 \\
\hline Landbouw & 46 & 13 & 19,9 \\
\hline Techniek & 13 & 20 & 20,5 \\
\hline Economie & 59 & 25 & 20,3 \\
\hline Gezondheidszorg & 86 & 11 & 20,7 \\
\hline BOL niveau $3 / 4$ & 58 & 10 & 22,0 \\
\hline Landbouw & 42 & 1 & 21,4 \\
\hline Techniek & 15 & 7 & 22,9 \\
\hline Economie & 59 & 15 & 21,3 \\
\hline Gezondheidszorg & 92 & 8 & 21,9 \\
\hline Gedrag en maatschappij & 91 & 12 & 22,0 \\
\hline BBL niveau $1 / 2$ & 28 & 9 & 24,3 \\
\hline Landbouw & 30 & 4 & 27,2 \\
\hline Techniek & 3 & 7 & 23,4 \\
\hline Economie & 54 & 11 & 25,0 \\
\hline Gezondheidszorg & 98 & 19 & 26,4 \\
\hline BBL niveau $3 / 4$ & 47 & 7 & 27,9 \\
\hline Landbouw & 33 & 1 & 25,1 \\
\hline Techniek & 2 & 6 & 26,2 \\
\hline Economie & 48 & 4 & 24,3 \\
\hline Gezondheidszorg & 92 & 8 & 31,6 \\
\hline Gedrag en maatschappij & 94 & 14 & 32,4 \\
\hline HBO & 55 & 6 & 24,9 \\
\hline Landbouw & 34 & 2 & 25,0 \\
\hline Onderwijs & 77 & 5 & 24,8 \\
\hline Techniek & 20 & 6 & 25,1 \\
\hline Economie & 51 & 8 & 24,5 \\
\hline Gezondheidszorg & 83 & 4 & 24,6 \\
\hline Gedrag en maatschappij & 84 & 7 & 24,6 \\
\hline Kunst en cultuur & 58 & 10 & 26,9 \\
\hline wo & 55 & 9 & 26,7 \\
\hline Landbouw & 48 & 6 & 26,1 \\
\hline Techniek & 19 & 9 & 27,0 \\
\hline Economie & 31 & 9 & 26,2 \\
\hline Gezondheidszorg & 67 & 11 & 27,4 \\
\hline Gedrag en maatschappij & 75 & 8 & 26,6 \\
\hline Taal en cultuur & 76 & 6 & 27,7 \\
\hline
\end{tabular}


Tabel A1.1 (vervolg)

De uitstroom van schoolverlaters verbijzonderd naar geslacht, etniciteit en gemiddelde leeftijd op moment van enquête

\begin{tabular}{lrrr}
\hline Opleidingssector & $\begin{array}{r}\text { vrouw } \\
\%\end{array}$ & $\begin{array}{r}\text { allochtoon } \\
\%\end{array}$ & $\begin{array}{r}\text { leeftijd } \\
\text { gem. }\end{array}$ \\
\hline wo (vervolg) & & & \\
Recht en openbare orde & 61 & 10 & 26,6 \\
Natuurwetenschappen & 49 & 10 & 25,8 \\
Totaal & $\mathbf{5 2}$ & & $\mathbf{2 1 , 3}$ \\
\hline
\end{tabular}

\section{Toelichting}

- Om als allochtoon te worden aangemerkt, dient de afgestudeerde of ten minste één van zijn of haar ouders te zijn geboren in één van de landen die worden genoemd in de Wet SAMEN (Stimulering Arbeidsdeelname Minderheden).

- Het betreft de leeftijd per onderzoeksdatum ongeveer anderhalf jaar na schoolverlaten.

- Voor het WO zijn de resultaten met betrekking tot allochtonen gebaseerd op 10 universiteiten. 


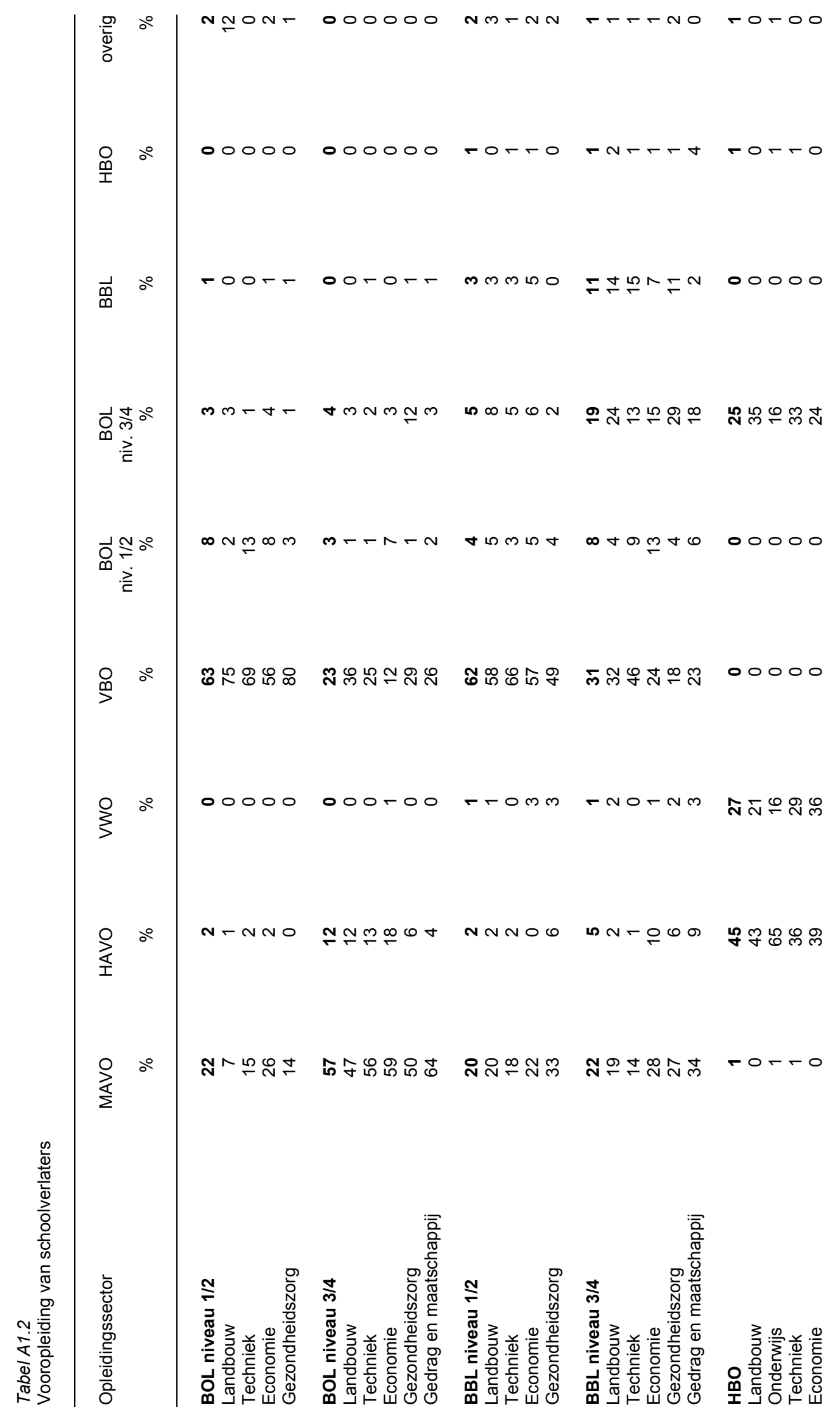




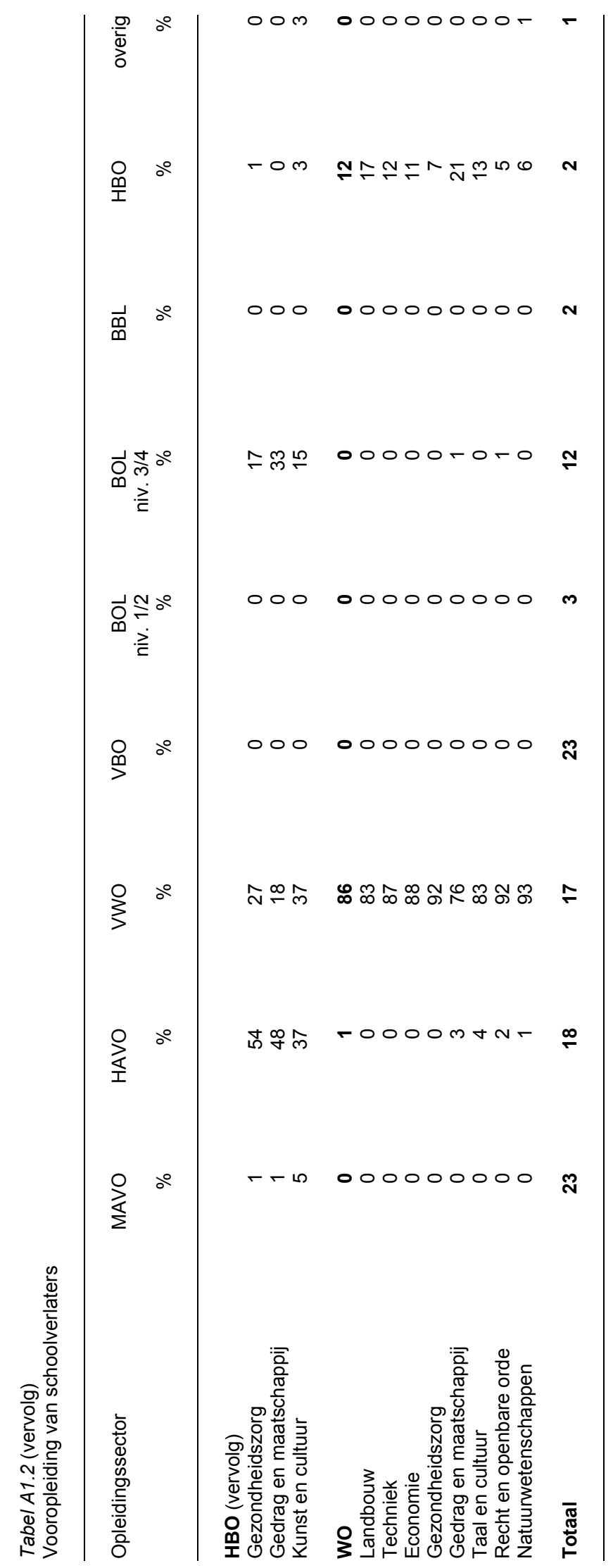


Tabel A1.3

Bestemming van schoolverlaters

\begin{tabular}{|c|c|c|c|c|c|}
\hline Opleidingssector & $\begin{array}{r}\text { studie } \\
\%\end{array}$ & $\begin{array}{r}\text { BBL } \\
\%\end{array}$ & $\begin{array}{r}\text { betaald werk } \\
\%\end{array}$ & $\begin{array}{r}\text { werkloos } \\
\%\end{array}$ & $\begin{array}{r}\text { anders } \\
\%\end{array}$ \\
\hline $\begin{array}{l}\text { AVO } \\
\text { MAVO } \\
\text { HAVO } \\
\text { VWO }\end{array}$ & $\begin{array}{l}83 \\
76 \\
85 \\
94\end{array}$ & $\begin{array}{r}5 \\
10 \\
2 \\
1\end{array}$ & $\begin{array}{r}8 \\
10 \\
10 \\
4\end{array}$ & $\begin{array}{l}1 \\
1 \\
1 \\
0\end{array}$ & $\begin{array}{l}2 \\
4 \\
2 \\
1\end{array}$ \\
\hline $\begin{array}{l}\text { VBO } \\
\text { IVBO } \\
\text { Landbouw } \\
\text { Techniek } \\
\text { Economie } \\
\text { Gezondheidszorg }\end{array}$ & $\begin{array}{l}50 \\
37 \\
51 \\
38 \\
56 \\
66\end{array}$ & $\begin{array}{l}20 \\
30 \\
13 \\
29 \\
12 \\
10\end{array}$ & $\begin{array}{l}25 \\
27 \\
29 \\
29 \\
25 \\
18\end{array}$ & $\begin{array}{l}2 \\
5 \\
3 \\
1 \\
2 \\
1\end{array}$ & $\begin{array}{l}4 \\
1 \\
4 \\
3 \\
5 \\
5\end{array}$ \\
\hline $\begin{array}{l}\text { BOL niveau 1/2 } \\
\text { Landbouw } \\
\text { Techniek } \\
\text { Economie } \\
\text { Gezondheidszorg }\end{array}$ & $\begin{array}{r}28 \\
4 \\
19 \\
29 \\
33\end{array}$ & $\begin{array}{r}9 \\
4 \\
15 \\
6 \\
12\end{array}$ & $\begin{array}{l}56 \\
91 \\
58 \\
56 \\
49\end{array}$ & $\begin{array}{l}4 \\
0 \\
3 \\
4 \\
3\end{array}$ & $\begin{array}{l}4 \\
0 \\
4 \\
4 \\
3\end{array}$ \\
\hline $\begin{array}{l}\text { BOL niveau } 3 / 4 \\
\text { Landbouw } \\
\text { Techniek } \\
\text { Economie } \\
\text { Gezondheidszorg } \\
\text { Gedrag en maatschappij }\end{array}$ & $\begin{array}{l}33 \\
28 \\
37 \\
35 \\
17 \\
38\end{array}$ & $\begin{array}{l}2 \\
2 \\
1 \\
1 \\
4 \\
2\end{array}$ & $\begin{array}{l}62 \\
67 \\
60 \\
60 \\
75 \\
55\end{array}$ & $\begin{array}{l}1 \\
1 \\
1 \\
1 \\
0 \\
1\end{array}$ & $\begin{array}{l}3 \\
3 \\
1 \\
3 \\
3 \\
4\end{array}$ \\
\hline $\begin{array}{l}\text { BBL niveau } 1 / 2 \\
\text { Landbouw } \\
\text { Techniek } \\
\text { Economie } \\
\text { Gezondheidszorg }\end{array}$ & $\begin{array}{l}3 \\
0 \\
3 \\
6 \\
0\end{array}$ & $\begin{array}{r}10 \\
4 \\
10 \\
10 \\
9\end{array}$ & $\begin{array}{l}81 \\
90 \\
80 \\
77 \\
90\end{array}$ & $\begin{array}{l}1 \\
1 \\
1 \\
2 \\
0\end{array}$ & $\begin{array}{l}5 \\
5 \\
6 \\
5 \\
1\end{array}$ \\
\hline $\begin{array}{l}\text { BBL niveau } \mathbf{3 / 4} \\
\text { Landbouw } \\
\text { Techniek } \\
\text { Economie } \\
\text { Gezondheidszorg } \\
\text { Gedrag en maatschappij }\end{array}$ & $\begin{array}{l}2 \\
1 \\
2 \\
4 \\
1 \\
3\end{array}$ & $\begin{array}{l}2 \\
2 \\
2 \\
1 \\
4 \\
0\end{array}$ & $\begin{array}{l}90 \\
91 \\
92 \\
90 \\
90 \\
86\end{array}$ & $\begin{array}{l}1 \\
0 \\
1 \\
1 \\
0 \\
1\end{array}$ & $\begin{array}{r}5 \\
6 \\
4 \\
3 \\
5 \\
10\end{array}$ \\
\hline $\begin{array}{l}\text { HBO } \\
\text { Landbouw } \\
\text { Onderwijs } \\
\text { Techniek } \\
\text { Economie } \\
\text { Gezondheidszorg } \\
\text { Gedrag en maatschappij } \\
\text { Kunst en cultuur }\end{array}$ & $\begin{array}{r}14 \\
13 \\
7 \\
17 \\
17 \\
10 \\
12 \\
15\end{array}$ & $\begin{array}{l}\mathbf{x} \\
\mathrm{X} \\
\mathrm{X} \\
\mathrm{X} \\
\mathrm{X} \\
\mathrm{X} \\
\mathrm{X} \\
\mathrm{X}\end{array}$ & $\begin{array}{l}82 \\
81 \\
90 \\
80 \\
79 \\
86 \\
83 \\
66\end{array}$ & $\begin{array}{l}2 \\
3 \\
1 \\
2 \\
2 \\
1 \\
2 \\
3\end{array}$ & $\begin{array}{r}3 \\
4 \\
2 \\
2 \\
2 \\
2 \\
2 \\
16\end{array}$ \\
\hline $\begin{array}{l}\text { WO } \\
\text { Landbouw } \\
\text { Techniek } \\
\text { Economie } \\
\text { Gezondheidszorg } \\
\text { Gedrag en maatschappij } \\
\text { Taal en cultuur } \\
\text { Recht en openbare orde } \\
\text { Natuurwetenschappen }\end{array}$ & $\begin{array}{l}3 \\
3 \\
2 \\
2 \\
5 \\
3 \\
4 \\
2 \\
7\end{array}$ & $\begin{array}{l}\mathbf{x} \\
\mathrm{x} \\
\mathrm{x} \\
\mathrm{x} \\
\mathrm{x} \\
\mathrm{x} \\
\mathrm{x} \\
\mathrm{x} \\
\mathrm{x}\end{array}$ & $\begin{array}{l}91 \\
91 \\
94 \\
95 \\
90 \\
91 \\
85 \\
93 \\
88\end{array}$ & $\begin{array}{l}2 \\
2 \\
2 \\
1 \\
2 \\
2 \\
3 \\
2 \\
2\end{array}$ & $\begin{array}{l}3 \\
3 \\
2 \\
2 \\
3 \\
4 \\
8 \\
2 \\
3\end{array}$ \\
\hline Totaal & 43 & 6 & 47 & 1 & 3 \\
\hline
\end{tabular}

$\mathrm{x}=$ antwoordcategorie niet opgenomen 
Tabel A1.4

Gevolgde opleiding opnieuw kiezen?

\begin{tabular}{|c|c|c|c|}
\hline Opleidingssector & $\begin{array}{r}\text { zelfde } \\
\text { opleiding } \\
\%\end{array}$ & $\begin{array}{r}\text { andere } \\
\text { opleiding } \\
\%\end{array}$ & $\begin{array}{r}\text { geen andere } \\
\text { opleiding } \\
\%\end{array}$ \\
\hline BOL niveau $1 / 2$ & 64 & 25 & 10 \\
\hline Landbouw & 63 & 19 & 18 \\
\hline Techniek & 61 & 26 & 12 \\
\hline Economie & 64 & 25 & 11 \\
\hline Gezondheidszorg & 68 & 26 & 6 \\
\hline BOL niveau $3 / 4$ & 78 & 21 & 1 \\
\hline Landbouw & 76 & 23 & 2 \\
\hline Techniek & 81 & 19 & 0 \\
\hline Economie & 70 & 28 & 1 \\
\hline Gezondheidszorg & 82 & 18 & 1 \\
\hline Gedrag en maatschappij & 85 & 14 & 1 \\
\hline BBL niveau $1 / 2$ & 78 & 16 & 7 \\
\hline Landbouw & 84 & 11 & 5 \\
\hline Techniek & 77 & 17 & 6 \\
\hline Economie & 74 & 16 & 11 \\
\hline Gezondheidszorg & 89 & 10 & 1 \\
\hline BBL niveau $3 / 4$ & 82 & 16 & 2 \\
\hline Landbouw & 79 & 15 & 6 \\
\hline Techniek & 87 & 12 & 1 \\
\hline Economie & 75 & 22 & 3 \\
\hline Gezondheidszorg & 82 & 16 & 2 \\
\hline Gedrag en maatschappij & 81 & 18 & 1 \\
\hline HBO & 74 & 25 & 0 \\
\hline Landbouw & 67 & 33 & 0 \\
\hline Onderwijs & 80 & 19 & 1 \\
\hline Techniek & 75 & 25 & 1 \\
\hline Economie & 70 & 29 & 0 \\
\hline Gezondheidszorg & 77 & 22 & 0 \\
\hline Gedrag en maatschappij & 72 & 28 & 1 \\
\hline Kunst en cultuur & 85 & 14 & 1 \\
\hline wo & 76 & 24 & 0 \\
\hline Landbouw & 57 & 43 & 0 \\
\hline Techniek & 75 & 24 & 1 \\
\hline Economie & 75 & 24 & 1 \\
\hline Gezondheidszorg & 80 & 20 & 0 \\
\hline Gedrag en maatschappij & 75 & 24 & 1 \\
\hline Taal en cultuur & 72 & 28 & 0 \\
\hline Recht en openbare orde & 82 & 18 & 0 \\
\hline Natuurwetenschappen & 71 & 29 & 0 \\
\hline Totaal & 76 & 22 & 2 \\
\hline
\end{tabular}

Toelichting

- Voor het WO hebben de resultaten betrekking op 12 universiteiten. 


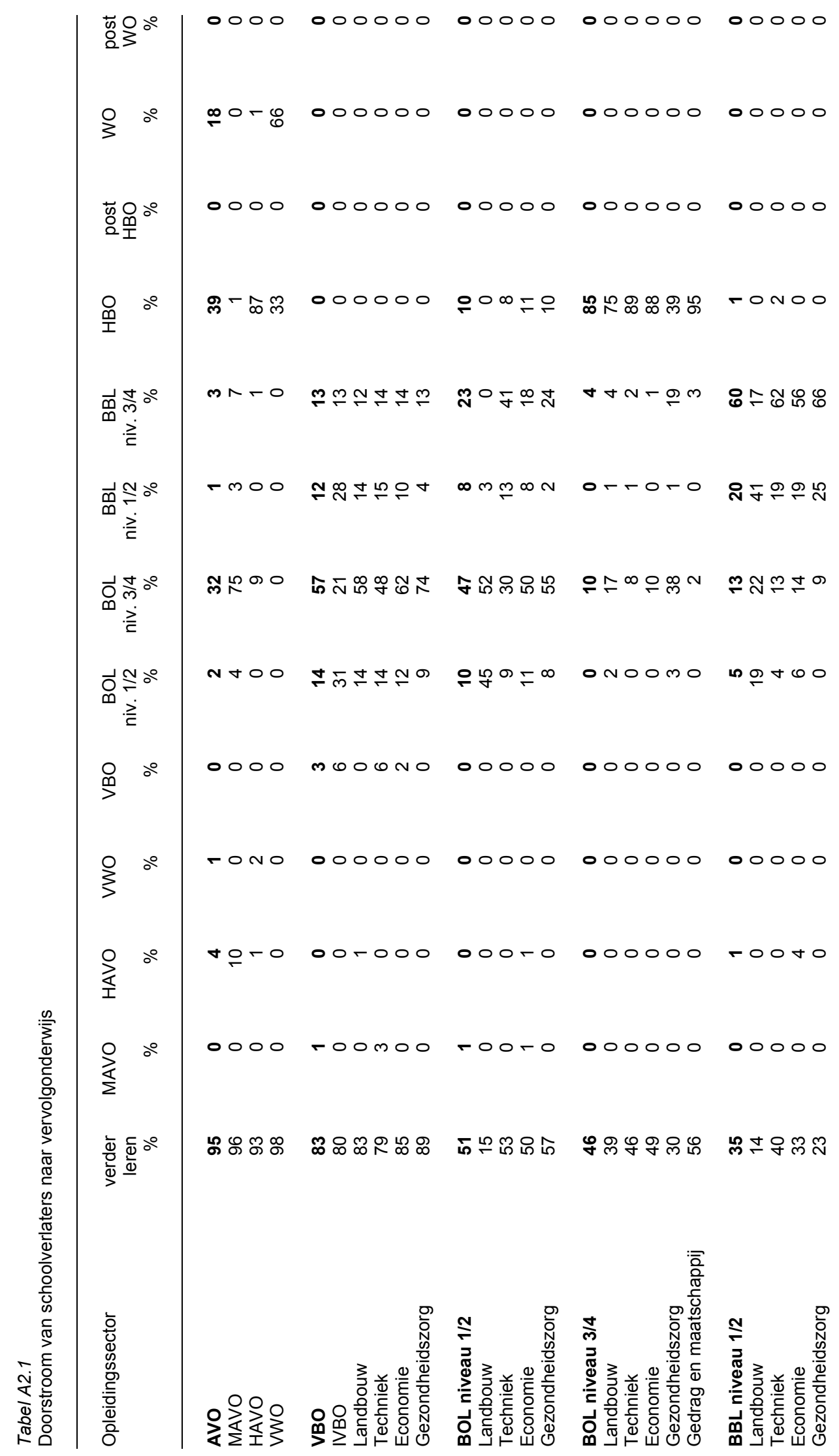




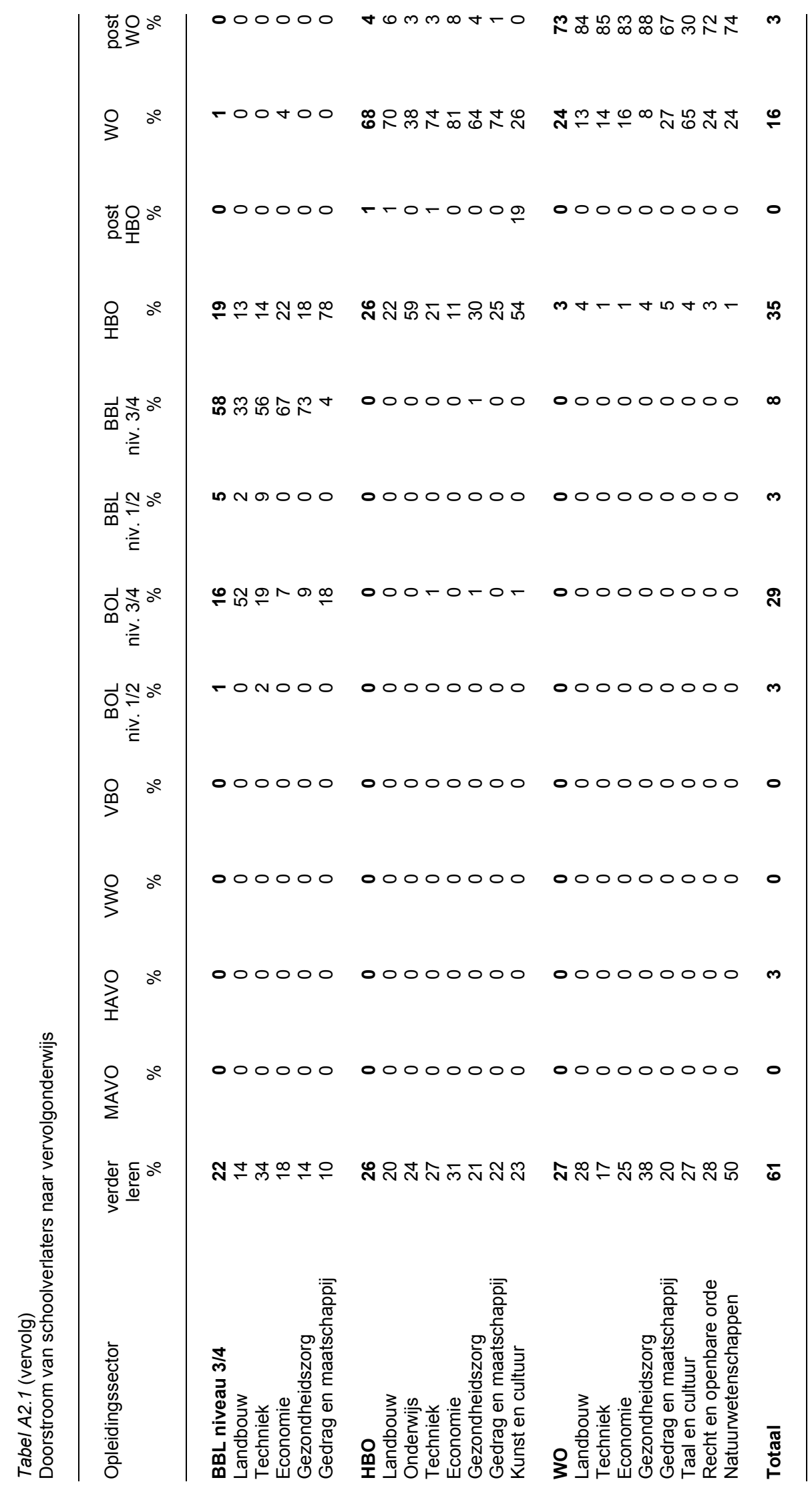


Tabel A2.2

Belangrijkste opleidingen van schoolverlaters die een voltijd vervolgopleiding zijn gaan volgen

MAVO

HAVO

BOL MKF Sociaal-pedagogisch werk

HAVO

HBO Leraar basisonderwijs

VWO

WO Economie

WO Geneeskunde

WO Nederlands recht

IVBO

BOL BB Helpende (verpleging en verzorging)

VBO techniek

BOL MKF Elektrotechnische installatietechniek

VBO gezondheidszorg

BOL MKF Sociaal-pedagogisch werk

BOL ZB Verzorgende

BOL ZB Sociaal-pedagogisch werk

BOL niveau 1/2 landbouw

BOL ZB Groene ruimte

BOL KF Dierverzorging en veterinaire ondersteuning

BOL KF Bloemschikken

BOL niveau $1 / 2$ techniek

BBL ZB Eerste autotechnicus

BOL MKF Motorvoertuigen

BBL ZB Constructie- en apparatenbouwer

BBL ZB Eerste monteur elektro en instrumentatie

BOL niveau $1 / 2$ economie

BOL MKF Directie-secretaresse/management-assistent

BOL niveau $1 / 2$ gezondheidszorg

BOL MKF Verzorgende

BOL MKF Sociaal-pedagogisch werk

BBL ZB Verzorgende

BBL ZB Verzorgende bij inst. voor gezinsverz.

BOL niveau 3/4 landbouw

HBO Veehouderij

HBO Tuin- en landschapsinrichting

BOL niveau 3/4 techniek

HBO Bouwkunde

HBO Elektrotechniek

HBO Werktuigbouwkunde

BOL niveau 3/4 economie

HBO Commerciele economie

HBO Management, economie en recht

HBO Communicatie 
Belangrijkste opleidingen van schoolverlaters die een voltijd vervolgopleiding zijn gaan volgen

BOL niveau 3/4 gezondheidszorg

BOL MKF Verpleegkundige

BBL MKF Verpleegkundige

HBO Opleiding tot verpleegkundige

BOL niveau $3 / 4$ gedrag en maatschappij

HBO Sociaal pedagogische hulpverlening

HBO Leraar basisonderwijs

HBO Maatschappelijk werk en dienstverlening

HBO Pedagogiek

$B B L$ niveau 1/2 landbouw

BBL BB Voedingsassistent

BOL BB Groene ruimte

BOL KF Groenvoorziening

BBL AB Groene ruimte

BOL MKF Sociaal-pedagogisch werk

BOL BB Dierverzorging en veterinaire ondersteuning

$B B L$ niveau $1 / 2$ techniek

BBL ZB Voortgezette timmerkracht

$B B L$ niveau $1 / 2$ economie

$\mathrm{BBL}$ ZB Zelfstandig werkend kok

BBL ZB Eerste verkoper

BBL BB Verkoopmedewerker

BBL ZB Verkoopchef

$B B L$ niveau $1 / 2$ gezondheidszorg

BBL ZB Verzorgende

BBL ZB Verzorgende bij inst. voor gezinsverz.

$B B L Z B$ Verpleging en verzorging

BBL BB Verkoopmedewerker

BBL BB Uiterlijke verzorging

BOL ZB Sociaal-pedagogisch werk

BBL MKF Verpleegkundige

BBL MKF Verpleging en verzorging

BBL niveau 3/4 landbouw

BBL KF Groene ruimte

BOL KF Groenbeheer

BOL ZB Voetverzorger

BOL MKF Internationale handel $(\mathrm{IH})$

HBO Beeldende kunst en vormgeving - vrij

BBL niveau 3/4 techniek

BBL MKF Assistent-uitvoerder B\&U

BBL niveau 3/4 economie

BBL ZB Verkoopchef

BBL MKF Ondernemer/manager detailhandel

BBL MKF Hoofd magazijn

BBL niveau 3/4 gezondheidszorg

BBL MKF Verpleegkundige

BBL Specialist Praktijkopleider (verpleging en verzorgende) 
Belangrijkste opleidingen van schoolverlaters die een voltijd vervolgopleiding zijn gaan volgen

BBL niveau 3/4 gedrag en maatschappij

HBO Sociaal pedagogische hulpverlening

HBO Leraar basisonderwijs

BOL MKF Sociaal-pedagogisch werk

HBO Diermanagement

HBO Pedagogiek

HBO landbouw

WO Bedrijfskunde

WO Levensmiddelentechnologie

WO Economie van landbouw en milieu

WO Master of Information Management

HBO onderwijs

HBO Leraar speciaal onderwijs

WO Pedagogische wetenschappen

HBO techniek

WO Bouwkunde

WO Bedrijfskunde

HBO economie

WO Bedrijfskunde

WO Bedrijfseconomie

WO Bedrijfswetenschappen

WO Nederlands recht

HBO gezondheidszorg

WO Gezondheidswetenschappen

WO Pedagogische wetenschappen

$\mathrm{HBO}$ Opleiding tot verpleegkundige

HBO Fysiotherapie

WO Bewegingswetenschappen

WO Psychologie

HBO gedrag en maatschappij

WO Pedagogische wetenschappen

WO Psychologie

WO Nederlands recht

WO Sociaal-culturele wetenschappen

WO Sociologie

HBO Leraar basisonderwijs

HBO taal en cultuur

HBO 2e Fase Muziek

HBO Muziek Vakopleiding

WO landbouw

$\mathrm{AIO} / \mathrm{OIO}$

WO techniek

$\mathrm{AlO} / \mathrm{OIO}$

Ontwerpersopleiding

WO economie

Post-doct. beroepsopl. Accountant

$\mathrm{AlO} / \mathrm{OlO}$

Post-doct. beroepsopl. Registeraccountant 
Tabel A2.2 (vervolg)

Belangrijkste opleidingen van schoolverlaters die een voltijd vervolgopleiding zijn gaan volgen

WO gezondheidszorg

AIO/OIO

Post-doct. beroepsopl. Medisch specialist (AGIO)

Post-doct. beroepsopl. Huisarts

WO gedrag en maatschappij

AIO/OIO

WO Kort Onderwijs

WO taal en cultuur

WO Kort Onderwijs

$\mathrm{AIO} / \mathrm{OIO}$

WO Nederlands recht

WO recht en openbare orde

Post-doct. beroepsopl. Advocatuur

$\mathrm{AlO} / \mathrm{OIO}$

Post-doct. beroepsopl. Kandidaat notaris opleiding

WO natuurwetenschappen

$\mathrm{AIO} / \mathrm{OIO}$

WO Kort Onderwijs

\section{Toelichting}

- In de tabel zijn alleen die opleidingen opgenomen die door ten minste 5\% van de schoolverlaters worden gevolgd. 
Tabel A2.3

Oordeel van schoolverlaters over de aansluiting van de afgesloten opleiding met de voltijd vervolgopleiding

\begin{tabular}{|c|c|c|c|c|}
\hline Opleidingssector & $\begin{array}{r}\text { goed } \\
\%\end{array}$ & $\begin{array}{r}\text { voldoende } \\
\%\end{array}$ & $\begin{array}{r}\text { matig } \\
\%\end{array}$ & $\begin{array}{r}\text { slecht } \\
\%\end{array}$ \\
\hline AVO & 29 & 45 & 20 & 6 \\
\hline MAVO & 28 & 46 & 20 & 7 \\
\hline HAVO & 25 & 45 & 23 & 7 \\
\hline VWO & 38 & 44 & 15 & 2 \\
\hline VBO & 34 & 40 & 18 & 8 \\
\hline IVBO & 35 & 44 & 17 & 4 \\
\hline Techniek & 32 & 34 & 24 & 10 \\
\hline Economie & 29 & 48 & 16 & 7 \\
\hline Gezondheidszorg & 41 & 41 & 12 & 6 \\
\hline BOL niveau $1 / 2$ & 43 & 33 & 17 & 6 \\
\hline Landbouw & 20 & 19 & 0 & 61 \\
\hline Techniek & 55 & 37 & 5 & 3 \\
\hline Economie & 41 & 35 & 18 & 7 \\
\hline Gezondheidszorg & 41 & 27 & 26 & 7 \\
\hline BOL niveau 3/4 & 34 & 37 & 21 & 8 \\
\hline Landbouw & 33 & 34 & 24 & 10 \\
\hline Techniek & 37 & 39 & 17 & 7 \\
\hline Economie & 33 & 35 & 23 & 9 \\
\hline Gezondheidszorg & 36 & 36 & 17 & 12 \\
\hline Gedrag en maatschappij & 30 & 39 & 24 & 7 \\
\hline HBO & 46 & 36 & 13 & 5 \\
\hline Landbouw & 40 & 36 & 14 & 10 \\
\hline Onderwijs & 50 & 35 & 12 & 4 \\
\hline Techniek & 48 & 36 & 12 & 4 \\
\hline Economie & 49 & 37 & 11 & 3 \\
\hline Gezondheidszorg & 41 & 40 & 13 & 6 \\
\hline Gedrag en maatschappij & 36 & 34 & 20 & 11 \\
\hline Kunst en cultuur & 49 & 34 & 11 & 6 \\
\hline Totaal & 33 & 42 & 19 & 6 \\
\hline
\end{tabular}

Toelichting

- Het gaat hier alleen om schoolverlaters die een voltijd vervolgopleiding zijn gaan volgen.

Vraag in de enquête:

- Hoe vindt u de aansluiting tussen uw [...] opleiding en deze vervolgopleiding? 
Tabel A2.4

Doorstroom van schoolverlaters naar de beroepsbegeleidende leerweg

MAVO

OVDB

ECABO

SVH

VEV/LOB-E

HAVO

OVDB

ECABO

GOC

Ken. en opl. centr. Handel

$\mathrm{SVH}$

VWO

OVDB

IVBO

OVDB

SOM

Ken. en opl. centr. Handel

VBO landbouw

OVDB

LOBAS

ECABO

SVH

Ken. en opl. centr. Handel

VBO techniek

VEV/LOB-E

SOM

VBO economie

ECABO

OVDB

Ken. en opl. centr. Handel

VBO gezondheidszorg

OVDB

KOC

BOL niveau 1/2 landbouw LOBAS

BOL niveau $1 / 2$ techniek

INNOVAM

VEV/LOB-E

SOM

VOC-Car

BOL niveau 1/2 economie

ECABO

Ken. en opl. centr. Handel

SVH

OVDB

BOL niveau $1 / 2$ gezondheidszorg

OVDB

SVH

ECABO 
Tabel A2.4 (vervolg)

Doorstroom van schoolverlaters naar de beroepsbegeleidende leerweg

BOL niveau 3/4 landbouw

LOBAS

ECABO

SOM

OVDB

SH\&M

BOL niveau 3/4 techniek

VaPro

VEV/LOB-E

SOM

BOL niveau 3/4 economie

ECABO

OVDB

Ken. en opl. centr. Handel

BOL niveau $3 / 4$ gezondheidszorg

OVDB

BOL niveau 3/4 gedrag en maatschappij

OVDB

BOL/BBL rest

$B B L$ niveau 1/2 landbouw

LOBAS

$B B L$ niveau $1 / 2$ techniek

Bouwradius

SOM

Intechnium

VEV/LOB-E

INNOVAM

BBL niveau $1 / 2$ economie Ken. en opl. centr. Handel

$B B L$ niveau $1 / 2$ gezondheidszorg

OVDB

KOC

Ken. en opl. centr. Handel

BBL niveau 3/4 landbouw LOBAS

Ken. en opl. centr. Handel

$\mathrm{KOC}$

BBL niveau 3/4 techniek

Intechnium

Bouwradius

VEV/LOB-E

SOM

INNOVAM

BBL niveau 3/4 economie Ken. en opl. centr. Handel

ECABO

SVH 
Tabel A2.4 (vervolg)

Doorstroom van schoolverlaters naar de beroepsbegeleidende leerweg

BBL niveau 3/4 gezondheidszorg

OVDB

BBL niveau 3/4 gedrag en maatschappij

OVDB

Ken. en opl. centr. Handel

\section{Toelichting}

- In de tabel zijn alleen die opleidingen opgenomen die door ten minste 5\% van de schoolverlaters worden gevolgd. 


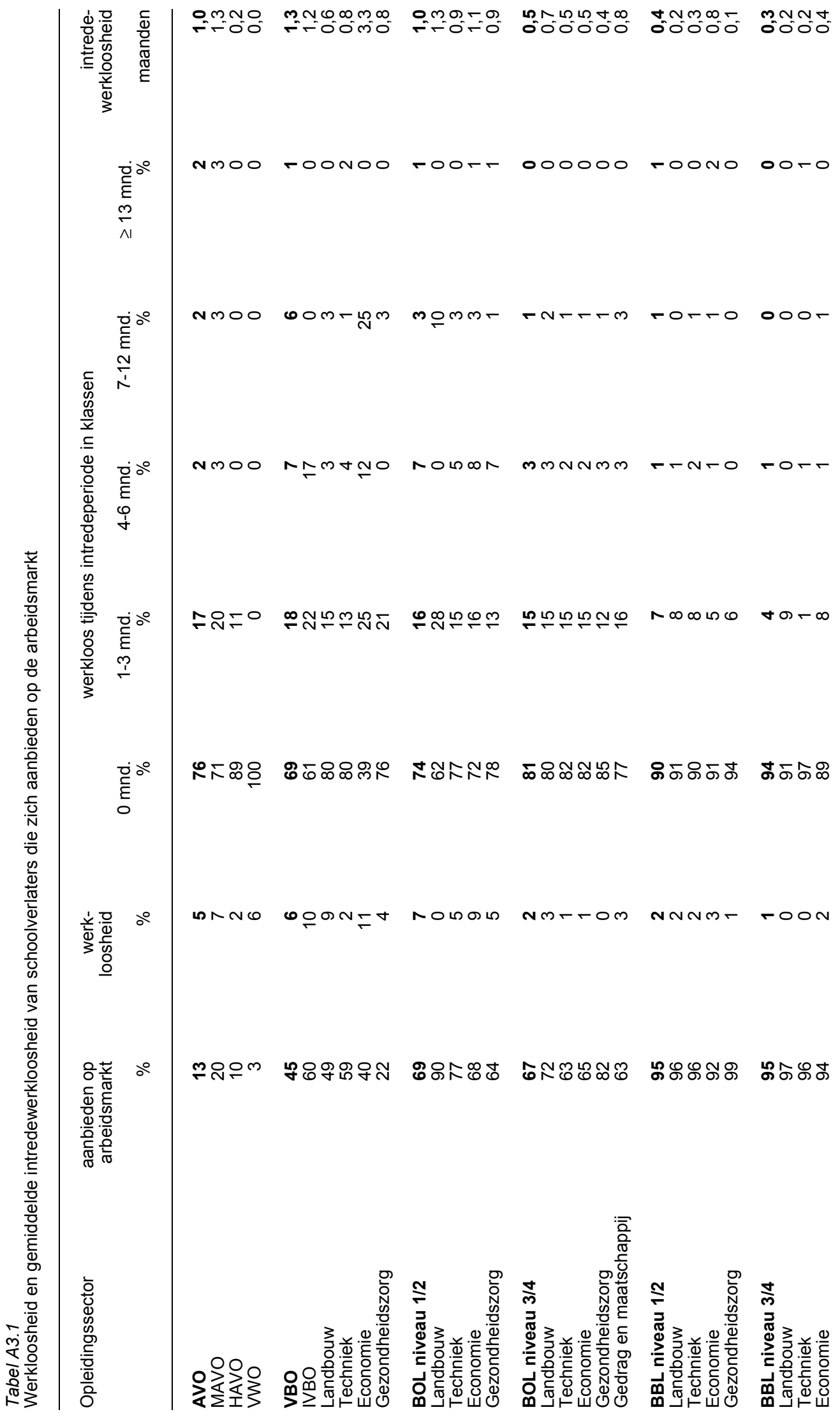




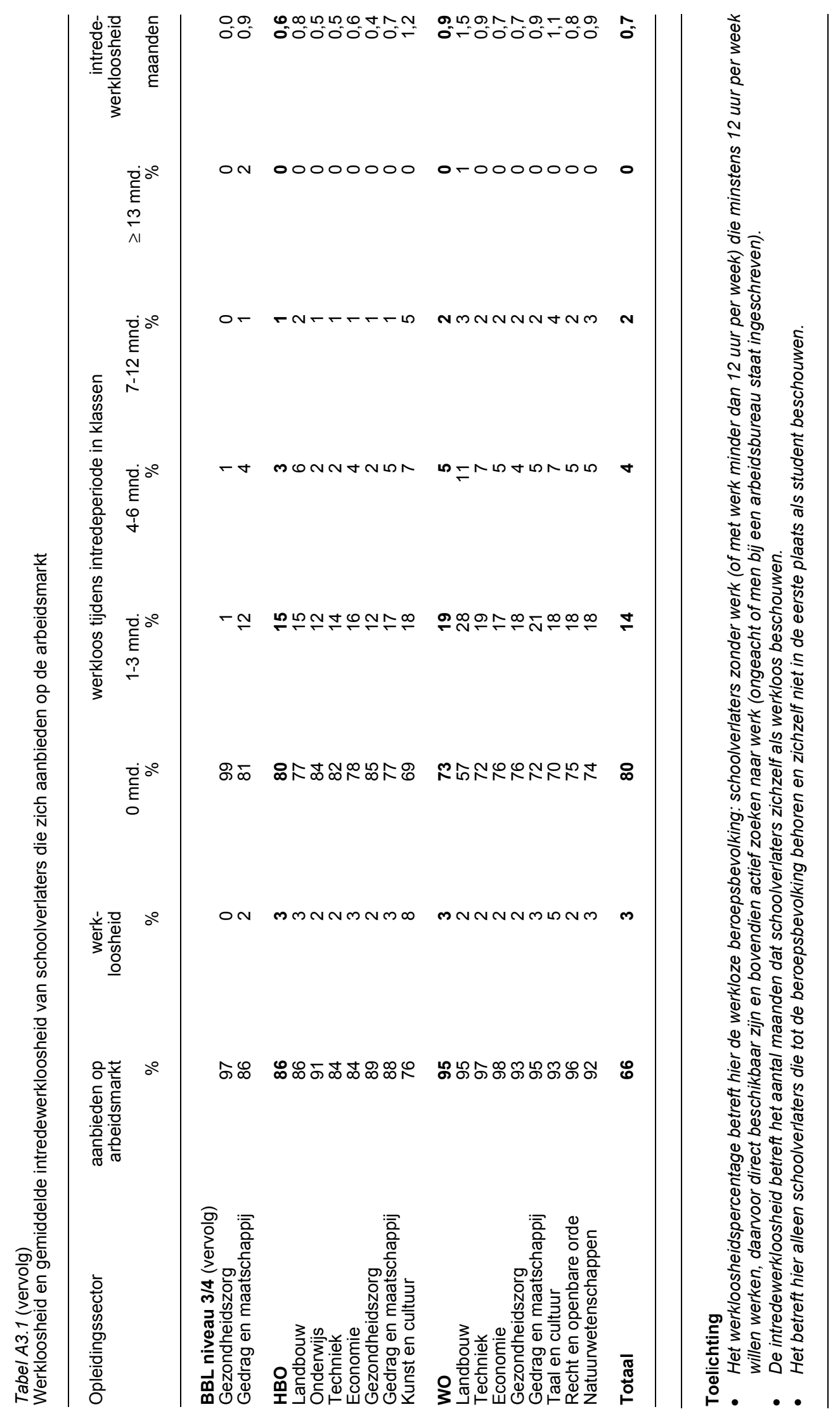




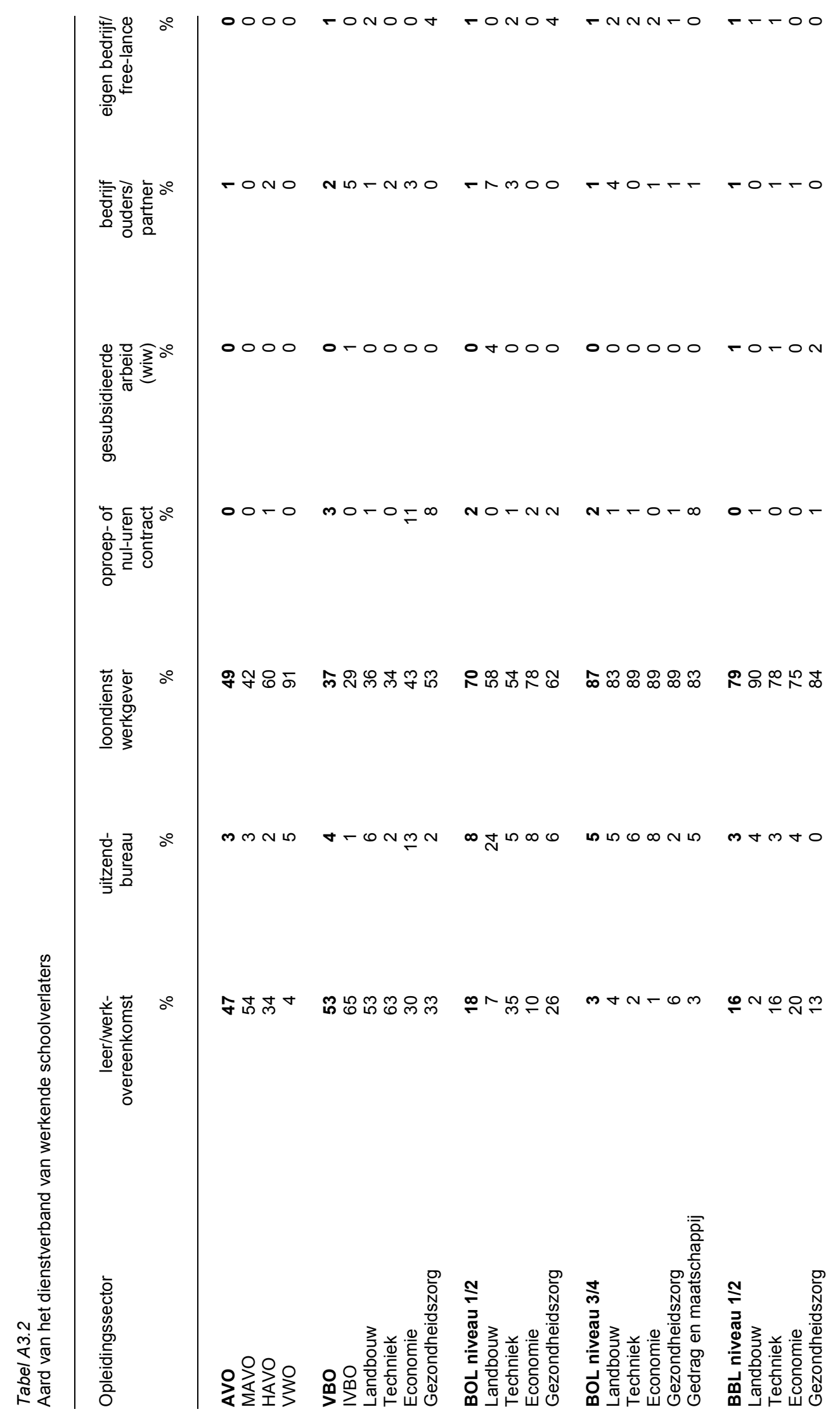




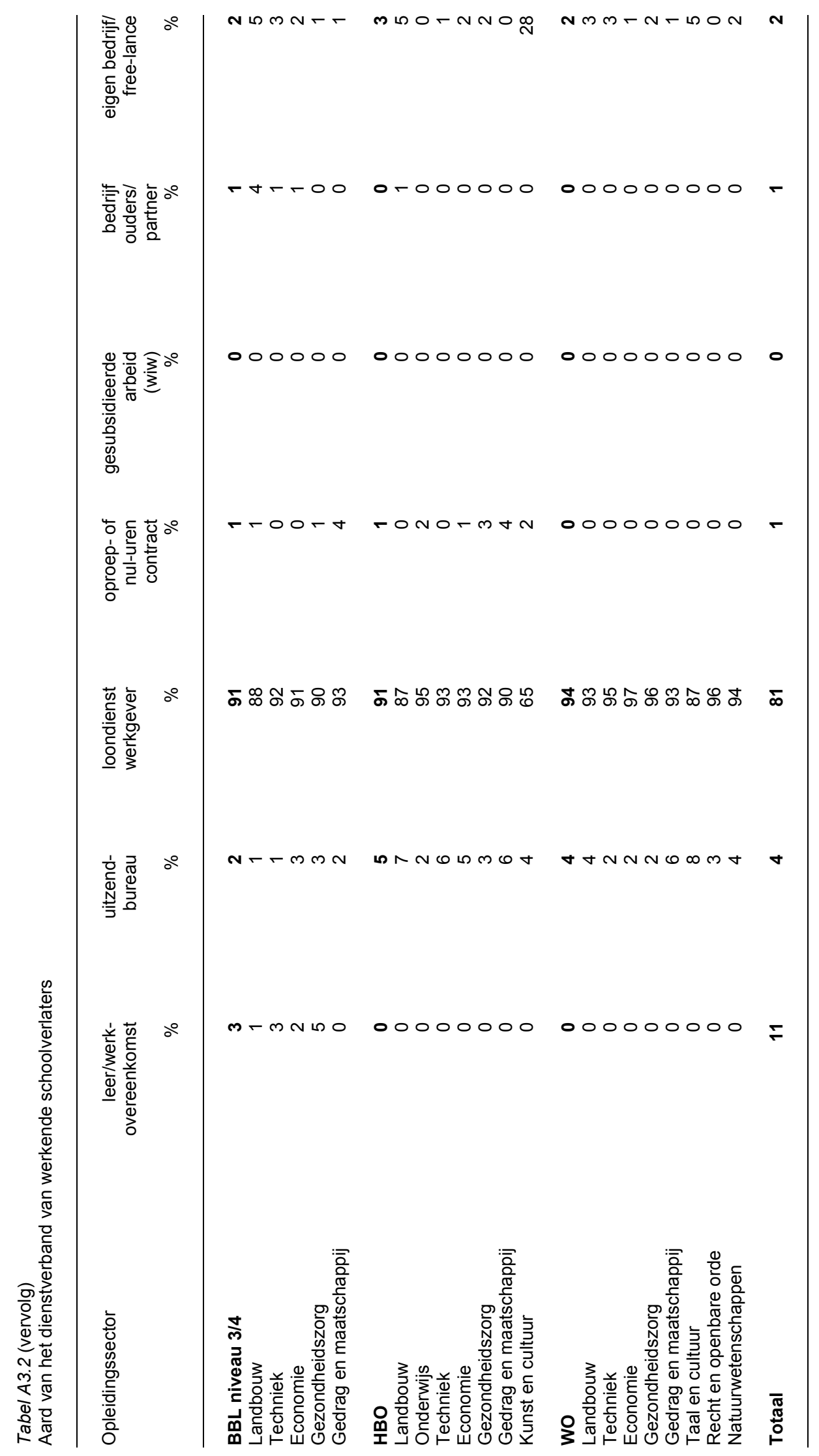


Tabel A3.3

Percentage werkende schoolverlaters met een flexibele aanstelling

Opleidingssector

AVO

MAVO

HAVO

VWO

VBO

17

IVBO

Landbouw

Techniek

Economie

Gezondheidszorg

BOL niveau 1/2

Landbouw

Techniek

34

Economie

Gezondheidszorg

18

24

BOL niveau 3/4

Landbouw

Techniek

13

Economie

Gezondheidszorg

Gedrag en maatschappij

BBL niveau 1/2

Landbouw

Techniek

Economie

Gezondheidszorg

BBL niveau $3 / 4$

Landbouw

Techniek

Economie

Gezondheidszorg

Gedrag en maatschappij

9

HBO

Landbouw

Onderwijs

Techniek

Economie

Gezondheidszorg

Gedrag en maatschappij

Kunst en cultuur

wo

Landbouw

Techniek

Economie

Gezondheidszorg

Gedrag en maatschappij

Taal en cultuur 
Tabel A3.3 (vervolg)

Percentage werkende schoolverlaters met een flexibele aanstelling

Opleidingssector

WO (vervolg)

Recht en openbare orde

Natuurwetenschappen

Totaal

Toelichting

- Voor het WO hebben de resultaten betrekking op 13 universiteiten.

- Een flexibele aanstelling betreft een aanstelling als uitzendkracht, oproepkracht e.d. of een aanstelling in tijdelijke dienst met een contract korter dan een jaar. 


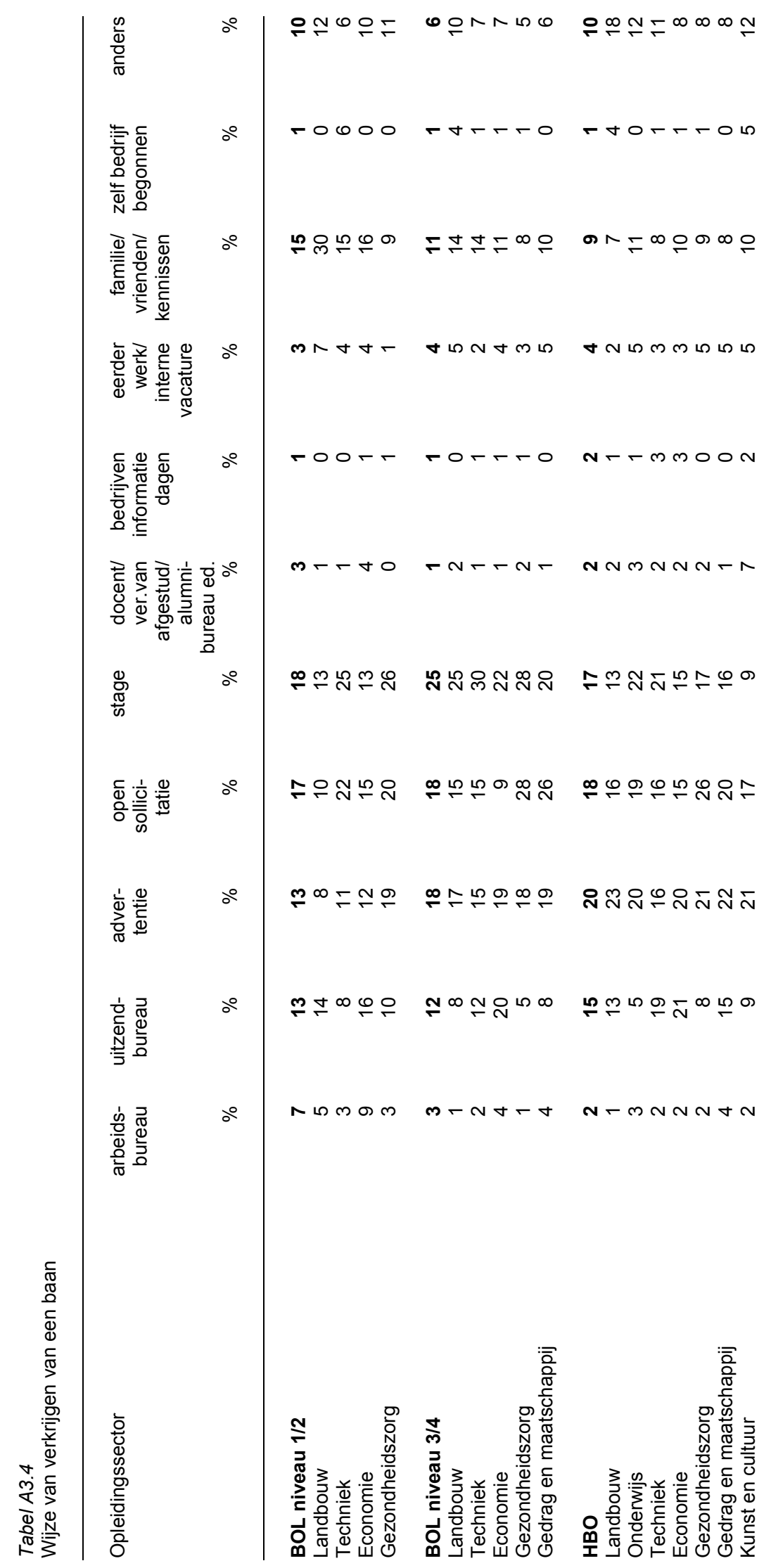




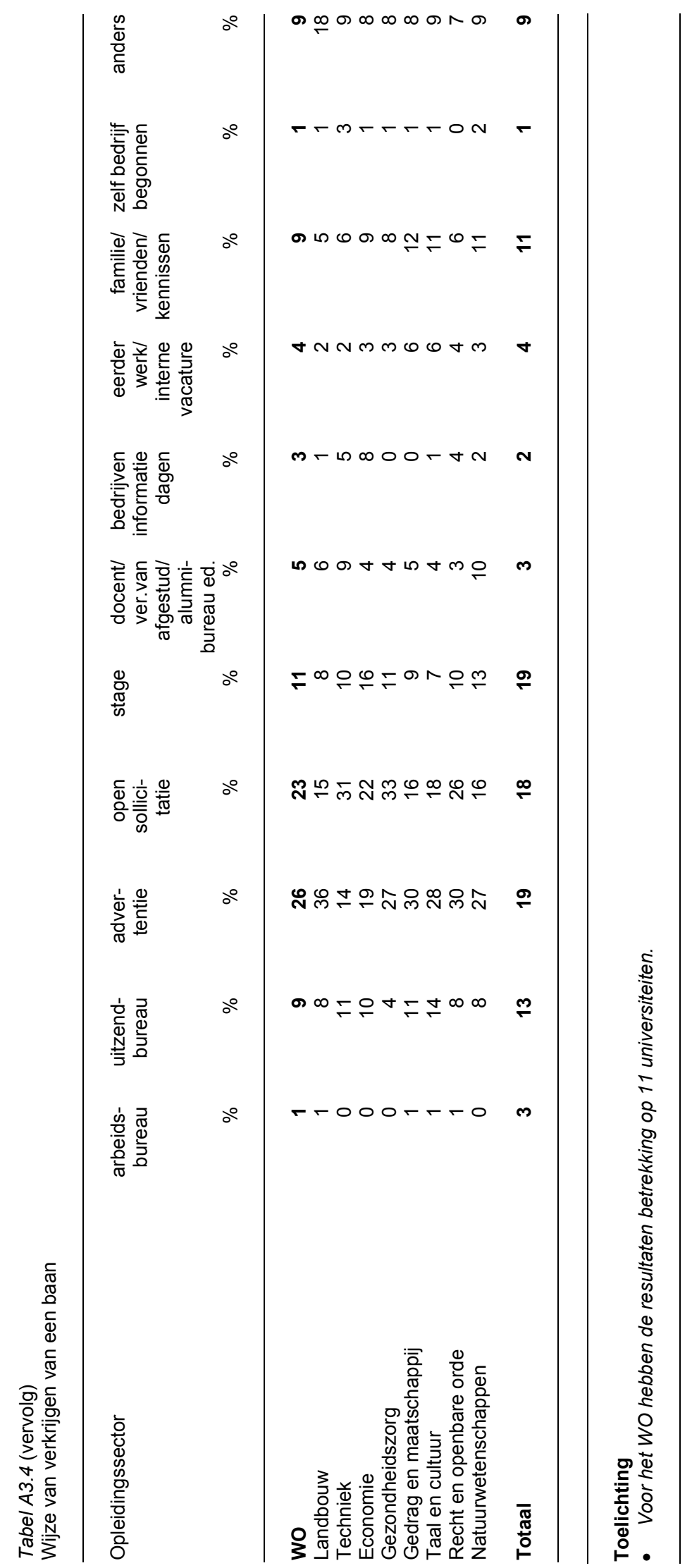


Tabel A3.5

Belangrijkste bedrijfsgroepen waarin schoolverlaters werkzaam zijn

MAVO

Ov. dienstverlening

Niet-gespec. detailh. in winkel

10

Welzijnszorg

Ov. gespec. detailh. in winkel

Gezondheidszorg

Restaurants/cafetaria's/snackbars ed

HAVO

Overheidsdienst.

Gezondheidszorg

Welzijnszorg

Rechtsk. dienstverl./account./belastingconsul./holdings ed

Geldscheppende financ. instell.

Niet-gespec. detailh. in winkel

\section{VWO}

Rechtsk. dienstverl./account./belastingconsul./holdings ed

Handel in/repar. auto's (2)

Post-/koeriersdiensten

Welzijnszorg

IVBO

Oppervlaktebehandeling/ov. metaalbewerking

Dienstverl. tbv landb. (excl. veterin.dienst.)

Niet-gespec. detailh. in winkel

Scheepsbouw/-reparatie

Welzijnszorg

Akker-/tuinbouw

Burgerl./utilit.;grond-/water-/wegenb. (excl. grondverz.)

\section{VBO landbouw}

Ov. gespec. detailh. in winkel

Niet-gespec. detailh. in winkel

Overheidsdienst.

Handel in/repar. auto's (1)

VBO techniek

Bouwnijverheid

Burgerl./utilit.;grond-/water-/wegenb. (excl. grondverz.)

Afwerken gebouwen

Bouwinstallatie

Ov. gespec. detailh. in winkel

Restaurants/cafetaria's/snackbars ed

VBO economie

Niet-gespec. detailh. in winkel

Ov. gespec. detailh. in winkel

Welzijnszorg

Drukkerijen/aanverwante activ.

Restaurants/cafetaria's/snackbars ed

\section{VBO gezondheidszorg}

Niet-gespec. detailh. in winkel

Ov. dienstverlening

Gezondheidszorg

Welzijnszorg

Vervoer over weg

Handel in/repar. auto's (1) 
VBO gezondheidszorg (vervolg)

Ov. gespec. detailh. in winkel

Textielveredeling

Restaurants/cafetaria's/snackbars ed

\section{BOL niveau 1/2 landbouw}

Ov. gespec. detailh. in winkel

Fokken/houden dieren

Akker-/tuinbouw

Openbaar bestuur

Sport

BOL niveau $1 / 2$ techniek

Bouwinstallatie

Handel in/repar. auto's (1)

Ov. gespec. detailh. in winkel

BOL niveau 1/2 economie

Niet-gespec. detailh. in winkel

Ov. gespec. detailh. in winkel

Overheidsdienst.

Welzijnszorg

Restaurants/cafetaria's/snackbars ed

Rechtsk. dienstverl./account./belastingconsul./holdings ed

BOL niveau $1 / 2$ gezondheidszorg

Welzijnszorg

Gezondheidszorg

Ov. dienstverlening

Restaurants/cafetaria's/snackbars ed

BOL niveau 3/4 landbouw

Ov. gespec. detailh. in winkel

Dienstverl. tbv landb. (excl. veterin.dienst.)
Akker-/tuinbouw

Veterinaire diensten

BOL niveau 3/4 techniek

Architecten-/ingenieurs-/ov. techn.ontw.-/teken-/adviesbureau

Burgerl./utilit.;grond-/water-/wegenb. (excl. grondverz.)

Telecommunicatie

Gezondheidszorg

BOL niveau 3/4 economie

Ov. gespec. detailh. in winkel

Rechtsk. dienstverl./account./belastingconsul./holdings ed

Hotels/pensions/conferentie-oorden

Geldscheppende financ. instell.

Verzekeringsw./pensioenfonds. (excl. verpl. soc.verzek.)

BOL niveau $3 / 4$ gezondheidszorg

Gezondheidszorg

Welzijnszorg

Detailh. farmac./med. art./parfum/cosmet. in winkel 12

Ov. dienstverlening

BOL niveau $3 / 4$ gedrag en maatschappij

Welzijnszorg

Gezondheidszorg 
BBL niveau 1/2 landbouw

$\begin{array}{ll}\text { Dienstverl. tbv landb. (excl. veterin.dienst.) } & 27\end{array}$

Ov. gespec. detailh. in winkel $\quad 13$

Akker-/tuinbouw 11

Vervaard. zuivelprodukten $\quad 11$

BBL niveau $1 / 2$ techniek

Burgerl./utilit.;grond-/water-/wegenb. (excl. grondverz.)

Afwerken gebouwen

Handel in/repar. auto's (1)

Ov. gespec. detailh. in winkel

BBL niveau $1 / 2$ economie

Ov. gespec. detailh. in winkel

Restaurants/cafetaria's/snackbars ed 16

$\begin{array}{ll}\text { Niet-gespec. detailh. in winkel } & 14\end{array}$

Hotels/pensions/conferentie-oorden $\quad 9$

BBL niveau $1 / 2$ gezondheidszorg

Ov. dienstverlening

Welzijnszorg

Gezondheidszorg

Niet-gespec. detailh. in winkel

BBL niveau 3/4 landbouw

Ov. gespec. detailh. in winkel

Dienstverl. tbv landb. (excl. veterin.dienst.)

Openbaar bestuur

Akker-/tuinbouw

BBL niveau 3/4 techniek

Burgerl./utilit.;grond-/water-/wegenb. (excl. grondverz.)

Bouwinstallatie

Handel in/repar. auto's (1)

Afwerken gebouwen

BBL niveau 3/4 economie

Ov. gespec. detailh. in winkel

Restaurants/cafetaria's/snackbars ed

Niet-gespec. detailh. in winkel

Hotels/pensions/conferentie-oorden

BBL niveau 3/4 gezondheidszorg

Welzijnszorg

Gezondheidszorg

Ov. dienstverlening

BBL niveau 3/4 gedrag en maatschappij

Welzijnszorg

HBO landbouw

Architecten-/ingenieurs-/ov. techn.ontw.-/teken-/adviesbur.

Openbaar bestuur

Rechtsk. dienstverl./account./belastingconsul./holdings ed

HBO onderwijs

Basisonderwijs voor leerplichtingen/speciaal onderwijs 
HBO techniek

Architecten-/ingenieurs-/ov. techn.ontw.-/teken-/adviesbur. Burgerl./utilit.;grond-/water-/wegenb. (excl. grondverz.)

Adviesbur. op gebied automat./systeemh.

Gezondheidszorg

HBO economie

Rechtsk. dienstverl./account./belastingconsul./holdings ed

Geldscheppende financ. instell.

Adviesbur. op gebied automat./systeemh.

Uitzendbur./uitleenbedr./arbeidsbemid./testen/werven/select.

HBO gezondheidszorg

Gezondheidszorg

HBO gedrag en maatschappij

Welzijnszorg

Gezondheidszorg

Uitzendbur./uitleenbedr./arbeidsbemid./testen/werven/select.

\section{HBO taal en cultuur}

Overig amusement/kunst

Reklamebureaus ed

Ov. zakelijke dienstverl. n.e.g.

Voortgezet onderwijs

WO landbouw

Hoger onderwijs

Openbaar bestuur

Rechtsk. dienstverl./account./belastingconsul./holdings ed

Architecten-/ingenieurs-/ov. techn.ontw.-/teken-/adviesbur.

Natuurwet. speur-/ontwikkelingsw.

\section{WO techniek}

Architecten-/ingenieurs-/ov. techn.ontw.-/teken-/adviesbur.

Hoger onderwijs

Adviesbur. op gebied automat./systeemh

Rechtsk. dienstverl./account./belastingconsul./holdings ed

Telecommunicatie

WO economie

Rechtsk. dienstverl./account./belastingconsul./holdings ed

Geldscheppende financ. instell.

Adviesbur. op gebied automat./systeemh.

Openbaar bestuur

\section{WO gezondheidszorg}

\section{Gezondheidszorg}

Hoger onderwijs

Veterinaire diensten

Welzijnszorg

WO gedrag en maatschappij

Rechtsk. dienstverl./account./belastingconsul./holdings ed 12

Gezondheidszorg

Welzijnszorg

Openbaar bestuur

Hoger onderwijs

Overheidsdienst. 
Tabel A3.5 (vervolg)

Belangrijkste bedrijfsgroepen waarin schoolverlaters werkzaam zijn

WO taal en cultuur

Rechtsk. dienstverl./account./belastingconsul./holdings ed

Hoger onderwijs

Openbaar bestuur

Voortgezet onderwijs

Uitgeverijen

WO recht en openbare orde

Rechtsk. dienstverl./account./belastingconsul./holdings ed $\quad 50$

Overheidsdienst

Openbaar bestuur

WO natuurwetenschappen

Hoger onderwijs

Gezondheidszorg

Detailh. farmac./med. art./parfum/cosmet. in winkel

Natuurwet. speur-/ontwikkelingsw.

Architecten-/ingenieurs-/ov. techn.ontw.-/teken-/adviesbur.

\section{Toelichting}

- De bedrijven waarin de schoolverlaters werkzaam zijn, zijn geclassificeerd volgens de Standaard Bedrijfs Indeling van het CBS. Op het hier gepresenteerde niveau van bedrijfsgroepen worden in totaal 211 categorieën onderscheiden.

- In de tabel zijn alleen die bedrijfsgroepen weergegeven waarin ten minste $5 \%$ van de schoolverlaters werkzaam is. 
Tabel A3.6

Belangrijkste beroepsgroepen waarin schoolverlaters werkzaam zijn

MAVO

Hulpkrachten horeca en verzorging

Verkopers

Verpleeghulpen en leerling-verpleegkundigen

Verzorgend personeel

Bouwvakkers

Assembleurs

HAVO

Receptionisten en administratieve employés

Aspirant politieagenten, soldaten en beveiligingshulpkrachten

Verpleeghulpen en leerling-verpleegkundigen

Boekhouders en secretaresses

Verkopers

Commercieel employés

Politieagenten, onderofficieren en beveiligingsemployés

VWO

Receptionisten en administratieve employés

Commercieel employés

Boekhouders en secretaresses

Verpleeghulpen en leerling-verpleegkundigen

IVBO

Metaalarbeiders

Bouwvakkers

Verkopers

Interieurverzorger

Monteurs

Laders en lossers

Agrarische arbeider

Assembleurs

VBO landbouw

Verkopers

Hulpkrachten horeca en verzorging

Laders en lossers

Agrarische arbeider

Assembleurs

Receptionisten en administratieve employés

VBO techniek

Bouwvakkers

Monteurs en controleurs elektrotechnische producten

Hulpkrachten horeca en verzorging

Aannemers en installateurs

Monteurs

Assembleurs

Verkopers

VBO economie

Verkopers

Receptionisten en administratieve employés

Hulpkrachten horeca en verzorging

Interieurverzorger

Assembleurs

Mechanisch operators

Winkeliers 


\section{VBO gezondheidszorg}

Verkopers

Hulpkrachten horeca en verzorging

Verzorgend personeel

Interieurverzorger

Laders en lossers

Productiemedewerker

Vakkenvuller

BOL niveau 1/2 landbouw

Agrarische arbeider

Verkopers

Landbouwmachinebestuurders en vissers

Procesoperators

BOL niveau 1/2 techniek

Aannemers en installateurs

Monteurs

Metaalarbeiders

Assembleurs

Elektromonteurs

Bankwerkers en lassers

Bouwvakkers

BOL niveau $1 / 2$ economie

Verkopers

Receptionisten en administratieve employés

Hulpkrachten horeca en verzorging

Boekhouders en secretaresses

Aspirant politieagenten, soldaten en beveiligingshulpkrachten

BOL niveau $1 / 2$ gezondheidszorg

Verzorgend personeel

Hulpkrachten horeca en verzorging

Interieurverzorger

Verkopers

Ziekenverzorgenden

BOL niveau 3/4 landbouw

Agrarische arbeider

Verkopers

Agrarische bedrijfshoofden

Agrarische vakkrachten

Verplegenden en doktersassistenten

BOL niveau 3/4 techniek

Aannemers en installateurs

Monteurs

Elektromonteurs

BOL niveau 3/4 economie

Boekhouders en secretaresses $\quad 24$

$\begin{array}{lll}2 & 17 \\ 17 & 17\end{array}$

Receptionisten en administratieve employés 14

Verkopers

Winkeliers

BOL niveau $3 / 4$ gezondheidszorg

Verplegenden en doktersassistenten 
BOL niveau 3/4 gezondheidszorg (vervolg)

Apothekersassistenten en medisch laboranten

BOL niveau 3/4 gedrag en maatschappij

Verzorgend personeel

Activiteitenbegeleiders en medewerkers arbeidsbemiddeling

Hulpkrachten horeca en verzorging

BBL niveau 1/2 landbouw

Agrarische arbeider

Verkopers

Procesoperators

Landbouwmachinebestuurders en vissers

$B B L$ niveau $1 / 2$ techniek

Bouwvakkers

Aannemers en installateurs

Chauffeurs

Monteurs

Metaalarbeiders

BBL niveau 1/2 economie

Verkopers

Verzorgend personeel

Hulpkrachten horeca en verzorging

Aspirant politieagenten, soldaten en beveiligingshulpkrachten

Receptionisten en administratieve employés

Laders en lossers

BBL niveau 1/2 gezondheidszorg

Verzorgend personeel

Hulpkrachten horeca en verzorging

Ziekenverzorgenden

Verpleeghulpen en leerling-verpleegkundigen

BBL niveau 3/4 landbouw

Verkopers

Agrarische bedrijfshoofden

Agrarische arbeider

Agrarische vakkrachten

BBL niveau 3/4 techniek

Aannemers en installateurs

Monteurs

Bouwvakkers

Elektromonteurs

BBL niveau 3/4 economie

Verzorgend personeel

Verkopers

Winkeliers

Boekhouders en secretaresses

Receptionisten en administratieve employés

Hulpkrachten horeca en verzorging

BBL niveau 3/4 gezondheidszorg 
BBL niveau 3/4 gezondheidszorg (vervolg)

Verplegenden en doktersassistenten

BBL niveau $3 / 4$ gedrag en maatschappij

Verzorgend personeel

Activiteitenbegeleiders en medewerkers arbeidsbemiddeling

HBO landbouw

Milieuhygienisten en agrarisch vertegenwoordigers $\quad 19$

Commercieel medewerkers $\quad 12$

Organisatie-adviseurs

Agrarische bedrijfshoofden

Assistent accountants

HBO onderwijs

Leraar basisonderwijs

Docenten talen en expressie

Docenten sociale vakken (2e en $3 \mathrm{e}$ gr.)

HBO techniek

Systeemanalisten

Architecten en bouwkundig projectleiders

Werktuigbouwkundig ontwerpers en hoofden technische dienst

Commercieel medewerkers

Technisch analisten

Organisatie-adviseurs

HBO economie

$\begin{array}{ll}\text { Commercieel medewerkers } & 27 \\ \text { Assistentaccountants } & 18\end{array}$

Assistent accountants $\quad 18$

$\begin{array}{lr}\text { Systeemanalisten } & 9\end{array}$

Commercieel employés $\quad 8$

Organisatie-adviseurs

HBO gezondheidszorg

Therapeuten en verpleegkundigen

HBO gedrag en maatschappij

Sociaal-cultureel werkers

Activiteitenbegeleiders en medewerkers arbeidsbemiddeling

HBO taal en cultuur

Kunstenaars

Docenten talen en expressie

Architecten en bouwkundig projectleiders

WO landbouw

Landbouwkundigen

Natuurwetenschappers

Artsen

Milieuhygienisten en agrarisch vertegenwoordigers

Economen

Materiaalkundigen

\section{WO techniek}

Weg- en waterbouwkundigen 
WO techniek (vervolg)

Organisatiedeskundigen

Systeemanalisten

Natuurwetenschappers

Werktuigbouwkundigen

Elektrotechnici

Informatici

Architecten en bouwkundig projectleiders

Wo economie

Economen

Commercieel medewerkers

Organisatiedeskundigen

Assistent accountants

Accountants

Organisatie-adviseurs

Systeemanalisten

WO gezondheidszorg

Artsen

WO gedrag en maatschappij

Sociaal-wetenschappelijk onderzoekers $\quad 20$

Sociaal-cultureel werkers

Onderwijskundigen en pedagogen

Commercieel medewerkers

Organisatiedeskundigen

Economen

Wo taal en cultuur

Commercieel medewerkers

Journalisten

Taalkundigen

Docenten talen en expressie

Docenten letteren (1e gr. en WO)

WO recht en openbare orde

Juristen

WO natuurwetenschappen

Natuurwetenschappers

\section{Toelichting}

- De beroepen waarin de schoolverlaters werkzaam zijn, zijn geclassificeerd volgens de Standaard Beroepenclassificatie 1992 van het CBS. Binnen de elementaire beroepen is hierbij door het ROA een nader onderscheid gemaakt. Bovendien zijn de namen van de beroepen verduidelijkt. Op het hier gepresenteerde niveau van beroepsgroepen worden in totaal 127 categorieën onderscheiden.

- In de tabel zijn alleen die beroepsgroepen weergegeven waarin ten minste 5\% van de schoolverlaters werkzaam is. 
Tabel A3.7

Grootte van de organisatie waarin schoolverlaters werkzaam zijn

\begin{tabular}{|c|c|c|c|c|c|}
\hline Opleidingssector & $\begin{array}{r}1 \text { pers } \\
\%\end{array}$ & $\begin{array}{r}2 \mathrm{t} / \mathrm{m} 9 \\
\text { pers } \\
\%\end{array}$ & $\begin{array}{r}10 \mathrm{t} / \mathrm{m} 99 \\
\text { pers } \\
\%\end{array}$ & $\begin{array}{r}100 \mathrm{t} / \mathrm{m} 999 \\
\text { pers } \\
\%\end{array}$ & $\begin{array}{r}\geq 1000 \\
\text { pers } \\
\%\end{array}$ \\
\hline AVO & 2 & 18 & 39 & 14 & 27 \\
\hline MAVO & 2 & 22 & 47 & 11 & 18 \\
\hline HAVO & 0 & 4 & 19 & 23 & 54 \\
\hline VWO & & 20 & 29 & 20 & 31 \\
\hline VBO & 1 & 23 & 44 & 17 & 14 \\
\hline IVBO & 4 & 22 & 49 & 9 & 16 \\
\hline Landbouw & 0 & 28 & 42 & 11 & 19 \\
\hline Techniek & 0 & 22 & 47 & 21 & 11 \\
\hline Economie & 3 & 21 & 39 & 21 & 16 \\
\hline Gezondheidszorg & & 28 & 34 & 16 & 22 \\
\hline BOL niveau $1 / 2$ & 1 & 17 & 35 & 25 & 22 \\
\hline Landbouw & 8 & 31 & 34 & 25 & 2 \\
\hline Techniek & 3 & 23 & 39 & 20 & 16 \\
\hline Economie & & 13 & 35 & 27 & 25 \\
\hline Gezondheidszorg & & 18 & 33 & 25 & 24 \\
\hline BOL niveau 3/4 & 1 & 14 & 31 & 26 & 28 \\
\hline Landbouw & 3 & 37 & 37 & 14 & 10 \\
\hline Techniek & 1 & 12 & 33 & 23 & 32 \\
\hline Economie & 1 & 12 & 33 & 23 & 31 \\
\hline Gezondheidszorg & 2 & 16 & 23 & 29 & 30 \\
\hline Gedrag en maatschappij & $\overline{0}$ & 6 & 31 & 38 & 25 \\
\hline BBL niveau $1 / 2$ & 1 & 18 & 41 & 21 & 20 \\
\hline Landbouw & 1 & 24 & 34 & 20 & 21 \\
\hline Techniek & 1 & 18 & 46 & 21 & 14 \\
\hline Economie & & 13 & 38 & 19 & 29 \\
\hline Gezondheidszorg & & 25 & 21 & 26 & 29 \\
\hline BBL niveau $3 / 4$ & 1 & 11 & 31 & 29 & 28 \\
\hline Landbouw & 3 & 29 & 38 & 21 & 9 \\
\hline Techniek & 2 & 13 & 40 & 22 & 22 \\
\hline Economie & & 9 & 38 & 18 & 35 \\
\hline Gezondheidszorg & 0 & 9 & 13 & 41 & 37 \\
\hline Gedrag en maatschappij & & 5 & 36 & 48 & 10 \\
\hline HBO & 1 & 8 & 30 & 29 & 32 \\
\hline Landbouw & 0 & 11 & 22 & 34 & 32 \\
\hline Onderwijs & 0 & 6 & 64 & 22 & 7 \\
\hline Techniek & 0 & 6 & 25 & 27 & 42 \\
\hline Economie & 1 & 6 & 24 & 29 & 41 \\
\hline Gezondheidszorg & 1 & 16 & 14 & 31 & 38 \\
\hline Gedrag en maatschappij & 0 & 5 & 21 & 46 & 28 \\
\hline Kunst en cultuur & 11 & 29 & 34 & 17 & 9 \\
\hline wo & 1 & 6 & 21 & 27 & 44 \\
\hline Landbouw & 1 & 6 & 13 & 31 & 49 \\
\hline Techniek & 1 & 9 & 20 & 19 & 51 \\
\hline Economie & 0 & 4 & 11 & 18 & 67 \\
\hline Gezondheidszorg & & 9 & 13 & 27 & 51 \\
\hline Gedrag en maatschappij & 1 & 5 & 27 & 33 & 34 \\
\hline Taal en cultuur & 2 & 10 & 32 & 28 & 27 \\
\hline
\end{tabular}


Tabel A3.7 (vervolg)

Grootte van de organisatie waarin schoolverlaters werkzaam zijn

\begin{tabular}{lrrrrr}
\hline Opleidingssector & 1 pers & $\begin{array}{r}2 \mathrm{t} / \mathrm{m} 9 \\
\text { pers } \\
\%\end{array}$ & $\begin{array}{r}10 \mathrm{t} / \mathrm{m} 99 \\
\text { pers } \\
\%\end{array}$ & $\begin{array}{r}100 \mathrm{t} / \mathrm{m} \text { 999 } \\
\text { pers } \\
\%\end{array}$ & $\begin{array}{r}\geq 1000 \\
\text { pers } \\
\%\end{array}$ \\
\hline $\begin{array}{l}\% \\
\text { Wecht en openbare orde }\end{array}$ & & & & & \\
Natuurwetenschappen & 0 & 5 & 24 & 39 & 32 \\
Totaal & 1 & 13 & 33 & 22 & 48 \\
\hline
\end{tabular}

\section{Toelichting}

- Voor het WO hebben de resultaten betrekking op 11 universiteiten.

Vraag in de enquête:

- Hoeveel mensen werken er bij de organisatie of het bedrijf waar u werkzaam bent? Het gaat hier om alle werknemers van het totale concern (hoofd- en nevenvestigingen samen). 
Tabel A3.8

Beloning van werkende schoolverlaters

\begin{tabular}{lrr}
\hline Opleidingssector & gemiddeld & gemiddeld \\
bruto maandloon & $€$ & bruto uurloon
\end{tabular}

AVO

MAVO

634

4,53
6,54

HAVO

989

WWO

VBO

642

4,35

IVBO

621

Landbouw

4,02

Techniek

615

4,14

Economie

4,62

Gezondheidszorg

556

624

3,96

BOL niveau 1/2

1.019

4,42

Landbouw

759

7,08

Techniek

1.163

4,96

Economie

1.013

7,22

Gezondheidszorg

BOL niveau 3/4

1.319

7,92

Landbouw

$\mathbf{8 , 7 0}$

Techniek

1.195

7,60

Economie

1.561

9,51

Gezondheidszorg

1.293

8,11

Gedrag en maatschappij

9,22

BBL niveau 1/2

1209

Landbouw

1.270

8,20

Techniek

1.289

8,25

Economie

1.386

8,75

Gezondheidszorg

1.092

7,23

BBL niveau 3/4

7,44

Landbouw

1.578

10,62

Techniek

1.404

10,62
8,82

Economie

1.844

1.430

Gezondheidszorg

1.458

11,29

Gedrag en maatschappij

8,84

11,34

HBO

1.187

9,95

Landbouw

Onderwijs

1.787

11,59

Techniek

1.795

10,93

12,04

11,70

Economie

1.948

11,57

Gezondheidszorg

1.612

1.594

12,00

Gedrag en maatschappij

11,19

Kunst en cultuur

10,47

wo

2.133

13,29

Landbouw

1.933

12,09

Techniek

2.282

13,71

Economie

2.344

13,96

Gezondheidszorg

2.371

14,50

Gedrag en maatschappij

1.991

13,31

Taal en cultuur

12,22 
Tabel A3.8 (vervolg)

Beloning van werkende schoolverlaters

Opleidingssector

gemiddeld

gemiddeld

bruto maandloon

bruto uurloon

$€$

WO (vervolg)

Recht en openbare orde

2.174

12,97

Natuurwetenschappen

Totaal

1.490

\section{Toelichting}

- Dit betreft het bruto inkomen in de baan waarin men het hoogste aantal uren werkt. Dit is inclusief toeslagen voor ploegendienst, fooien, provisie e.d. maar exclusief inkomen uit overwerk, vakantiegeld, $13^{e}$ maand, uitkering, e.d. Er is hier niet gecorrigeerd voor verschillen in leeftijd van de schoolverlaters.

- Voor het WO is het bruto uurloon gebaseerd op 12 universiteiten. 
Tabel A3.9

Vereist opleidingsniveau voor de huidige functie volgens de werkgever

\begin{tabular}{|c|c|c|c|}
\hline Opleidingssector & $\begin{array}{c}\text { lager } \\
\%\end{array}$ & $\begin{array}{r}\text { zelfde } \\
\%\end{array}$ & $\begin{array}{r}\text { hoger } \\
\%\end{array}$ \\
\hline $\begin{array}{l}\text { AVO } \\
\text { MAVO } \\
\text { HAVO } \\
\text { VWO }\end{array}$ & $\begin{array}{r}15 \\
20 \\
6 \\
6\end{array}$ & $\begin{array}{r}29 \\
32 \\
24 \\
6\end{array}$ & $\begin{array}{l}56 \\
48 \\
71 \\
88\end{array}$ \\
\hline $\begin{array}{l}\text { VBO } \\
\text { IVBO } \\
\text { Landbouw } \\
\text { Techniek } \\
\text { Economie } \\
\text { Gezondheidszorg }\end{array}$ & $\begin{array}{l}23 \\
27 \\
23 \\
17 \\
31 \\
27\end{array}$ & $\begin{array}{l}48 \\
41 \\
57 \\
43 \\
55 \\
60\end{array}$ & $\begin{array}{l}30 \\
32 \\
21 \\
40 \\
14 \\
13\end{array}$ \\
\hline $\begin{array}{l}\text { BOL niveau } \mathbf{1 / 2} \\
\text { Landbouw } \\
\text { Techniek } \\
\text { Economie } \\
\text { Gezondheidszorg }\end{array}$ & $\begin{array}{l}54 \\
61 \\
40 \\
62 \\
44\end{array}$ & $\begin{array}{l}26 \\
32 \\
44 \\
17 \\
37\end{array}$ & $\begin{array}{r}20 \\
7 \\
17 \\
21 \\
20\end{array}$ \\
\hline $\begin{array}{l}\text { BOL niveau } 3 / 4 \\
\text { Landbouw } \\
\text { Techniek } \\
\text { Economie } \\
\text { Gezondheidszorg } \\
\text { Gedrag en maatschappij }\end{array}$ & $\begin{array}{l}29 \\
46 \\
25 \\
32 \\
25 \\
25\end{array}$ & $\begin{array}{l}68 \\
53 \\
71 \\
64 \\
74 \\
71\end{array}$ & $\begin{array}{l}3 \\
1 \\
4 \\
5 \\
1 \\
4\end{array}$ \\
\hline $\begin{array}{l}\text { BBL niveau } \mathbf{1 / 2} \\
\text { Landbouw } \\
\text { Techniek } \\
\text { Economie } \\
\text { Gezondheidszorg }\end{array}$ & $\begin{array}{l}51 \\
61 \\
48 \\
63 \\
37\end{array}$ & $\begin{array}{l}35 \\
29 \\
41 \\
19 \\
40\end{array}$ & $\begin{array}{l}14 \\
11 \\
11 \\
18 \\
23\end{array}$ \\
\hline $\begin{array}{l}\text { BBL niveau } 3 / 4 \\
\text { Landbouw } \\
\text { Techniek } \\
\text { Economie } \\
\text { Gezondheidszorg } \\
\text { Gedrag en maatschappij }\end{array}$ & $\begin{array}{l}46 \\
53 \\
67 \\
51 \\
21 \\
32\end{array}$ & $\begin{array}{l}52 \\
45 \\
32 \\
46 \\
77 \\
66\end{array}$ & $\begin{array}{l}2 \\
2 \\
1 \\
3 \\
2 \\
1\end{array}$ \\
\hline $\begin{array}{l}\text { HBO } \\
\text { Landbouw } \\
\text { Onderwijs } \\
\text { Techniek } \\
\text { Economie } \\
\text { Gezondheidszorg } \\
\text { Gedrag en maatschappij } \\
\text { Taal en cultuur }\end{array}$ & $\begin{array}{l}21 \\
27 \\
12 \\
17 \\
19 \\
21 \\
38 \\
35\end{array}$ & $\begin{array}{l}78 \\
73 \\
87 \\
82 \\
79 \\
79 \\
62 \\
63\end{array}$ & $\begin{array}{l}1 \\
0 \\
0 \\
1 \\
2 \\
0 \\
1 \\
2\end{array}$ \\
\hline $\begin{array}{l}\text { WO } \\
\text { Landbouw } \\
\text { Techniek } \\
\text { Economie } \\
\text { Gezondheidszorg } \\
\text { Gedrag en maatschappij } \\
\text { Taal en cultuur } \\
\text { Recht en openbare orde } \\
\text { Natuurwetenschappen }\end{array}$ & $\begin{array}{l}34 \\
36 \\
33 \\
41 \\
10 \\
45 \\
59 \\
18 \\
26\end{array}$ & $\begin{array}{l}66 \\
64 \\
67 \\
59 \\
90 \\
55 \\
41 \\
82 \\
74\end{array}$ & \\
\hline Totaal & 33 & 59 & 8 \\
\hline
\end{tabular}

Toelichting

Vraag in de enquête:

- Welk opleidingsniveau werd door uw werkgever voor deze functie minimaal vereist? 
Tabel A3.10

Vereiste opleidingsrichting voor de huidige functie volgens de werkgever

\begin{tabular}{|c|c|c|c|}
\hline Opleidingssector & $\begin{array}{r}\text { eigen/verwante } \\
\text { richting } \\
\%\end{array}$ & $\begin{array}{r}\text { andere } \\
\text { richting } \\
\%\end{array}$ & $\begin{array}{r}\text { geen } \\
\text { richting } \\
\%\end{array}$ \\
\hline VBO & 55 & 6 & 39 \\
\hline IVBO & 66 & 10 & 24 \\
\hline Landbouw & 46 & 8 & 46 \\
\hline Techniek & 68 & 5 & 28 \\
\hline Economie & 31 & 8 & 60 \\
\hline Gezondheidszorg & 31 & 3 & 66 \\
\hline BOL niveau $1 / 2$ & 54 & 6 & 40 \\
\hline Landbouw & 48 & & 52 \\
\hline Techniek & 62 & 8 & 30 \\
\hline Economie & 45 & 6 & 49 \\
\hline Gezondheidszorg & 75 & 3 & 22 \\
\hline BOL niveau 3/4 & 72 & 7 & 21 \\
\hline Landbouw & 63 & 7 & 30 \\
\hline Techniek & 75 & 9 & 16 \\
\hline Economie & 63 & 8 & 29 \\
\hline Gezondheidszorg & 81 & 4 & 15 \\
\hline Gedrag en maatschappij & 75 & 7 & 18 \\
\hline BBL niveau 1/2 & 62 & 7 & 31 \\
\hline Landbouw & 43 & 4 & 54 \\
\hline Techniek & 70 & 4 & 26 \\
\hline Economie & 44 & 13 & 43 \\
\hline Gezondheidszorg & 71 & 8 & 21 \\
\hline BBL niveau $3 / 4$ & 74 & 6 & 19 \\
\hline Landbouw & 68 & 5 & 26 \\
\hline Techniek & 75 & 5 & 19 \\
\hline Economie & 58 & 7 & 35 \\
\hline Gezondheidszorg & 83 & 7 & 10 \\
\hline Gedrag en maatschappij & 83 & 8 & 9 \\
\hline HBO & 76 & 4 & 20 \\
\hline Landbouw & 71 & 8 & 22 \\
\hline Onderwijs & 88 & 3 & 9 \\
\hline Techniek & 80 & 3 & 17 \\
\hline Economie & 62 & 5 & 33 \\
\hline Gezondheidszorg & 92 & 2 & 5 \\
\hline Gedrag en maatschappij & 77 & 6 & 17 \\
\hline Kunst en cultuur & 69 & 8 & 23 \\
\hline wo & 71 & 4 & 24 \\
\hline Landbouw & 70 & 9 & 22 \\
\hline Techniek & 75 & 3 & 22 \\
\hline Economie & 70 & 2 & 28 \\
\hline Gezondheidszorg & 93 & 1 & 6 \\
\hline Gedrag en maatschappij & 61 & 7 & 32 \\
\hline Taal en cultuur & 47 & 9 & 43 \\
\hline Recht en openbare orde & 82 & 3 & 15 \\
\hline Natuurwetenschappen & 78 & 3 & 19 \\
\hline Totaal & 69 & 6 & 26 \\
\hline
\end{tabular}

\section{Toelichting}

Vraag in de enquête:

- Welke opleidingsrichting werd door uw werkgever voor deze functie vereist? 
Tabel A3.11

Gewenste en feitelijke wekelijkse arbeidsduur van werkende schoolverlaters

\begin{tabular}{|c|c|c|}
\hline Opleidingssector & $\begin{array}{r}\text { gewenste } \\
\text { wekelijkse } \\
\text { arbeidsduur } \\
\text { uren }\end{array}$ & $\begin{array}{r}\text { feitelijke } \\
\text { wekelijkse } \\
\text { arbeidsduur } \\
\text { uren }\end{array}$ \\
\hline AVO & 35,3 & 32,7 \\
\hline MAVO & 34,8 & 31,7 \\
\hline HAVO & 37,4 & 36,5 \\
\hline VWO & 32,0 & 28,5 \\
\hline VBO & 35,8 & 33,5 \\
\hline IVBO & 37,7 & 35,3 \\
\hline Landbouw & 36,4 & 33,7 \\
\hline Techniek & 37,1 & 34,8 \\
\hline Economie & 32,5 & 30,8 \\
\hline Gezondheidszorg & 33,0 & 30,1 \\
\hline BOL niveau $1 / 2$ & 36,6 & 35,4 \\
\hline Landbouw & 37,3 & 36,7 \\
\hline Techniek & 39,0 & 38,8 \\
\hline Economie & 36,2 & 35,7 \\
\hline Gezondheidszorg & 35,3 & 31,1 \\
\hline BOL niveau 3/4 & 36,6 & 36,3 \\
\hline Landbouw & 39,0 & 38,3 \\
\hline Techniek & 39,2 & 38,9 \\
\hline Economie & 37,3 & 38,0 \\
\hline Gezondheidszorg & 34,4 & 33,5 \\
\hline Gedrag en maatschappij & 33,3 & 32,1 \\
\hline BBL niveau $1 / 2$ & 38,3 & 36,7 \\
\hline Landbouw & 36,8 & 35,8 \\
\hline Techniek & 40,1 & 38,1 \\
\hline Economie & 36,7 & 35,1 \\
\hline Gezondheidszorg & 32,8 & 33,1 \\
\hline BBL niveau 3/4 & 35,0 & 34,8 \\
\hline Landbouw & 37,7 & 37,1 \\
\hline Techniek & 38,6 & 38,6 \\
\hline Economie & 36,8 & 36,8 \\
\hline Gezondheidszorg & 30,8 & 30,3 \\
\hline Gedrag en maatschappij & 28,5 & 27,5 \\
\hline HBO & 35,8 & 36,8 \\
\hline Landbouw & 37,4 & 39,5 \\
\hline Onderwijs & 34,3 & 35,6 \\
\hline Techniek & 38,0 & 39,3 \\
\hline Economie & 37,3 & 38,5 \\
\hline Gezondheidszorg & 33,5 & 33,7 \\
\hline Gedrag en maatschappij & 33,6 & 33,7 \\
\hline Kunst en cultuur & 30,1 & 30,3 \\
\hline Wo & 36,6 & 38,3 \\
\hline Landbouw & 36,5 & 38,3 \\
\hline Techniek & 37,6 & 39,4 \\
\hline Economie & 38,3 & 39,8 \\
\hline Gezondheidszorg & 37,0 & 39,3 \\
\hline Gedrag en maatschappij & 34,7 & 36,1 \\
\hline Taal en cultuur & 34,2 & 35,9 \\
\hline
\end{tabular}


Tabel A3.11 (vervolg)

Gewenste en feitelijke wekelijkse arbeidsduur van werkende schoolverlaters

\begin{tabular}{lrr}
\hline Opleidingssector & $\begin{array}{r}\text { gewenste } \\
\text { wekelijkse } \\
\text { arbeidsduur } \\
\text { uren }\end{array}$ & $\begin{array}{r}\text { feitelijke } \\
\text { wekelijkse } \\
\text { arbeidsduur } \\
\text { uren }\end{array}$ \\
WO (vervolg) & & \\
Recht en openbare orde & 37,6 & 39,4 \\
Natuurwetenschappen & 36,6 & 38,3 \\
Totaal & 36,3 & 36,1 \\
\end{tabular}

\section{Toelichting}

- De feitelijke arbeidsduur betreft zowel het aantal uren in de hoofdfunctie als het aantal uren in eventuele nevenfuncties.

- Voor het WO zijn de resultaten gebaseerd op 12 universiteiten.

De gewenste wekelijkse arbeidsduur is bepaald op basis van de vraag in de enquête:

- Als u zelf zou mogen kiezen, hoeveel uren per week zou u dan het liefst betaald werk willen hebben? 
Tabel A3.12

Oordeel van de werkende schoolverlaters over de aansluiting tussen de afgesloten opleiding en de huidige functie

\begin{tabular}{|c|c|c|c|c|}
\hline Opleidingssector & $\begin{array}{r}\text { goed } \\
\%\end{array}$ & $\begin{array}{r}\text { voldoende } \\
\%\end{array}$ & $\begin{array}{r}\text { matig } \\
\%\end{array}$ & $\begin{array}{r}\text { slecht } \\
\%\end{array}$ \\
\hline BOL niveau $1 / 2$ & 40 & 40 & 10 & 10 \\
\hline Landbouw & 53 & 22 & 15 & 10 \\
\hline Techniek & 38 & 44 & 11 & 8 \\
\hline Economie & 35 & 43 & 12 & 11 \\
\hline Gezondheidszorg & 56 & 30 & 5 & 10 \\
\hline BOL niveau $3 / 4$ & 44 & 39 & 12 & 5 \\
\hline Landbouw & 46 & 36 & 12 & 6 \\
\hline Techniek & 36 & 45 & 14 & 5 \\
\hline Economie & 40 & 43 & 13 & 4 \\
\hline Gezondheidszorg & 58 & 30 & 7 & 5 \\
\hline Gedrag en maatschappij & 46 & 35 & 13 & 6 \\
\hline BBL niveau $1 / 2$ & 58 & 28 & 8 & 5 \\
\hline Landbouw & 53 & 28 & 8 & 10 \\
\hline Techniek & 56 & 29 & 9 & 6 \\
\hline Economie & 59 & 30 & 7 & 4 \\
\hline Gezondheidszorg & 72 & 21 & 5 & 2 \\
\hline BBL niveau 3/4 & 60 & 30 & 7 & 3 \\
\hline Landbouw & 57 & 32 & 5 & 5 \\
\hline Techniek & 60 & 33 & 6 & 2 \\
\hline Economie & 50 & 34 & 10 & 7 \\
\hline Gezondheidszorg & 68 & 24 & 5 & 2 \\
\hline Gedrag en maatschappij & 64 & 24 & 9 & 3 \\
\hline HBO & 46 & 37 & 11 & 5 \\
\hline Landbouw & 38 & 42 & 11 & 8 \\
\hline Onderwijs & 58 & 28 & 8 & 6 \\
\hline Techniek & 44 & 42 & 10 & 4 \\
\hline Economie & 43 & 39 & 13 & 5 \\
\hline Gezondheidszorg & 53 & 35 & 9 & 2 \\
\hline Gedrag en maatschappij & 44 & 37 & 12 & 7 \\
\hline Kunst en cultuur & 39 & 32 & 13 & 16 \\
\hline wo & 53 & 32 & 10 & $\mathbf{5}$ \\
\hline Landbouw & 59 & 24 & 11 & 6 \\
\hline Techniek & 50 & 37 & 10 & 3 \\
\hline Economie & 62 & 28 & 7 & 2 \\
\hline Gezondheidszorg & 67 & 26 & 5 & 3 \\
\hline Gedrag en maatschappij & 45 & 36 & 15 & 5 \\
\hline Taal en cultuur & 33 & 35 & 17 & 15 \\
\hline Recht en openbare orde & 56 & 33 & 7 & 4 \\
\hline Natuurwetenschappen & 51 & 31 & 10 & 7 \\
\hline Totaal & 50 & 35 & 10 & 5 \\
\hline
\end{tabular}

\section{Toelichting}

- Voor het WO hebben de resultaten betrekking op 12 universiteiten.

Vraag in de enquête:

- Hoe vindt u de aansluiting tussen uw [...] opleiding en uw huidige functie? 
Tabel A3.13

Percentage werkende schoolverlaters dat op zoek is naar een andere baan

Opleidingssector

AVO

MAVO

HAVO

VWO

VBO

IVBO

Landbouw

Techniek

Economie

Gezondheidszorg

BOL niveau 1/2

Landbouw

Techniek

Economie

Gezondheidszorg

BOL niveau $3 / 4$

Landbouw

Techniek

Economie

Gezondheidszorg

Gedrag en maatschappij

BBL niveau $1 / 2$

Landbouw

Techniek

Economie

Gezondheidszorg

BBL niveau 3/4

Landbouw

Techniek

Economie

Gezondheidszorg

Gedrag en maatschappij

HBO

Landbouw

Onderwijs

Techniek

Economie

Gezondheidszorg

Gedrag en maatschappij

Kunst en cultuur

WO

Landbouw

Techniek

Economie

Gezondheidszorg

Gedrag en maatschappij

Taal en cultuur

Recht en openbare orde

Natuurwetenschappen

Totaal

Toelichting

Vraag in de enquête:

- Heeft $u$ in de afgelopen vier weken iets gedaan om aan ander werk te komen? 
Tabel A3.14

Deelname aan een cursus of bedrijfsopleiding door werkende schoolverlaters

\begin{tabular}{ll}
\hline Opleidingssector & $\%$ \\
\hline
\end{tabular}

BOL niveau 1/2 32

Landbouw 13

$\begin{array}{ll}\text { Techniek } & 43\end{array}$

Economie $\quad 32$

Gezondheidszorg $\quad 23$

$\begin{array}{ll}\text { BOL niveau 3/4 } & 37\end{array}$

Landbouw $\quad 26$

$\begin{array}{ll}\text { Techniek } & 47\end{array}$

Economie $\quad 42$

Gezondheidszorg

$\begin{array}{ll}\text { Gedrag en maatschappij } & 27\end{array}$

HBO

42

Landbouw $\quad 40$

Onderwijs $\quad 30$

$\begin{array}{ll}\text { Techniek } & 50\end{array}$

$\begin{array}{ll}\text { Economie } & 47\end{array}$

Gezondheidszorg $\quad 42$

Gedrag en maatschappij $\quad 42$

$\begin{array}{lr}\text { Kunst en cultuur } & 15\end{array}$

WO

$\begin{array}{ll}\text { Landbouw } & 52\end{array}$

Techniek $\quad 50$

Economie $\quad 62$

Gezondheidszorg $\quad 28$

Gedrag en maatschappij $\quad 43$

Taal en cultuur $\quad 33$

Recht en openbare orde $\quad 55$

Natuurwetenschappen $\quad 36$

$\begin{array}{ll}\text { Totaal } & 40\end{array}$

Toelichting

- Voor het WO hebben de resultaten betrekking op 11 universiteiten.

Vraag in de enquête:

Heeft u na het verlaten van de [...] opleiding een cursus of bedrijfsopleiding gevolgd? 
Tabel A3.15

Belangrijkste cursussen of bedrijfsopleidingen waaraan werkende schoolverlaters deelnemen

BOL niveau 1/2 landbouw

$\mathrm{BB}$, bedrijfszelfbescherming

BOL niveau $1 / 2$ techniek

$\mathrm{BB}$, bedrijfszelfbescherming

Techniek

Elektrotechniek

Computer en informatica

Bouwkunde

Weg-, railvervoer

Uiterlijke verzorging

Natuurkunde, materiaalkunde

BOL niveau $1 / 2$ economie

Marketing, reclame

Administratief

Verzekeringswezen

$\mathrm{BB}$, bedrijfszelfbescherming

Bedrijfskunde, management, efficiency

Bedrijfsadministratie, accountancy

Recht

Communicatieve vaardigheden

BOL niveau $1 / 2$ gezondheidszorg

Administratief

Uiterlijke verzorging

Verpleging

Detailhandel (incl. middenstandsdiploma)

Bejaardenverzorging

Sociaal werk

Algemeen

Bedrijfskunde, management, efficiency

Commercieel

BOL niveau 3/4 landbouw

$\mathrm{BB}$, bedrijfszelfbescherming

Weg-, railvervoer

Bedrijfskunde, management, efficiency

Computer en informatica

BOL niveau 3/4 techniek

Computer en informatica

$\mathrm{BB}$, bedrijfszelfbescherming

Bedrijfskunde, management, efficiency

Techniek

Elektrische energietechniek

BOL niveau 3/4 economie

Geld- en bankzaken

Bedrijfskunde, management, efficiency

Verzekeringswezen

Computer en informatica

BOL niveau $3 / 4$ gezondheidszorg 
BOL niveau 3/4 gedrag en maatschappij

Communicatieve vaardigheden

Verpleging

Gezondheidszorg

Geneeskunde

Gedrag en maatschappij

$\mathrm{BB}$, bedrijfszelfbescherming

Computer en informatica

HBO landbouw

Geld- en bankzaken

13

Bedrijfskunde, management, efficiency

Communicatieve vaardigheden

Computer en informatica

$\mathrm{BB}$, bedrijfszelfbescherming

Recht

HBO onderwijs

Computer en informatica

Pedagog.-didactische cursussen voor leerkrachten

Basisonderwijs/onderwijzers (incl. remedial teacher)

HBO techniek

Computer en informatica

Bedrijfskunde, management, efficiency

$\mathrm{BB}$, bedrijfszelfbescherming

HBO economie

Computer en informatica

Bedrijfskunde, management, efficiency

Geld- en bankzaken

Communicatieve vaardigheden

Marketing, reclame

Verzekeringswezen

HBO gezondheidszorg

Verpleging

Fysiotherapie, bewegingsleer

Geneeskunde

Gezondheidszorg

Communicatieve vaardigheden

HBO gedrag en maatschappij

Communicatieve vaardigheden

Recht

Bedrijfskunde, management, efficiency

Gedrag en maatschappij

HBO taal en cultuur

Computer en informatica

Communicatieve vaardigheden

WO landbouw

Bedrijfskunde, management, efficiency

Communicatieve vaardigheden

Computer en informatica

Techniek 
Tabel A3.15 (vervolg)

Belangrijkste cursussen of bedrijfsopleidingen waaraan werkende schoolverlaters deelnemen

WO techniek

Bedrijfskunde, management, efficiency

Computer en informatica

Communicatieve vaardigheden

Algemeen

WO economie

Bedrijfskunde, management, efficiency

Computer en informatica

Geld- en bankzaken

Communicatieve vaardigheden

\section{WO gezondheidszorg}

Geneeskunde

Communicatieve vaardigheden

Gezondheidszorg

Verpleging

Computer en informatica

Bedrijfskunde, management, efficiency

WO gedrag en maatschappij

Bedrijfskunde, management, efficiency $\quad 18$

$\begin{array}{ll}\text { Communicatieve vaardigheden } & 15\end{array}$

Recht

WO taal en cultuur

Computer en informatica

Bedrijfskunde, management, efficiency

Marketing, reclame

Communicatie

Communicatieve vaardigheden

WO recht en openbare orde

Recht

Recht en openbare orde

Belastingen

Geld- en bankzaken

Communicatieve vaardigheden

WO natuurwetenschappen

Bedrijfskunde, management, efficiency 16

Computer en informatica

Communicatieve vaardigheden

Geneeskunde

Farmacie

\section{Toelichting}

- Voor het WO hebben de resultaten betrekking op 11 universiteiten.

- In de tabel zijn alleen die cursussen en bedrijfsopleidingen opgenomen waaraan ten minste $5 \%$ van de schoolverlaters deelneemt. 


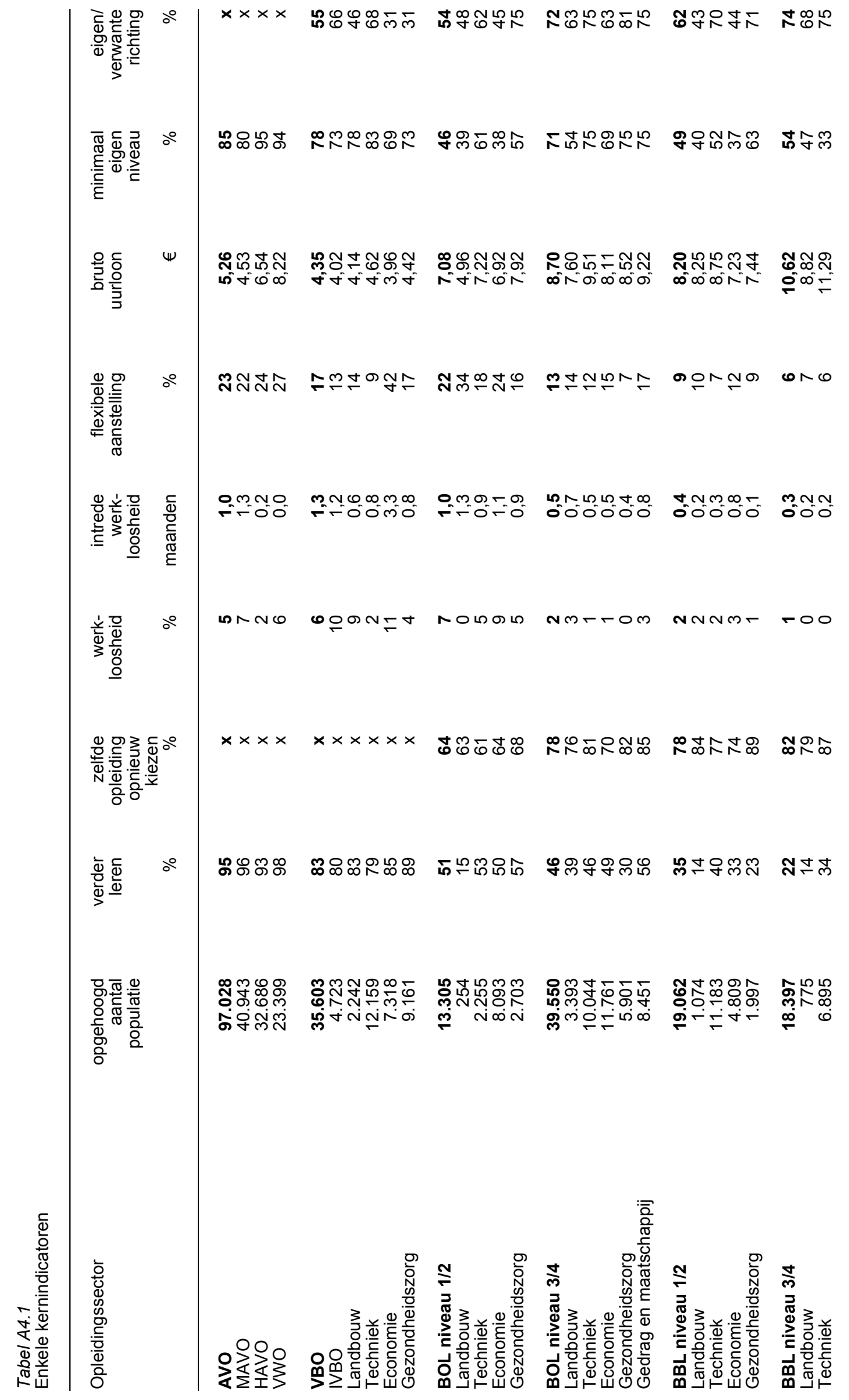




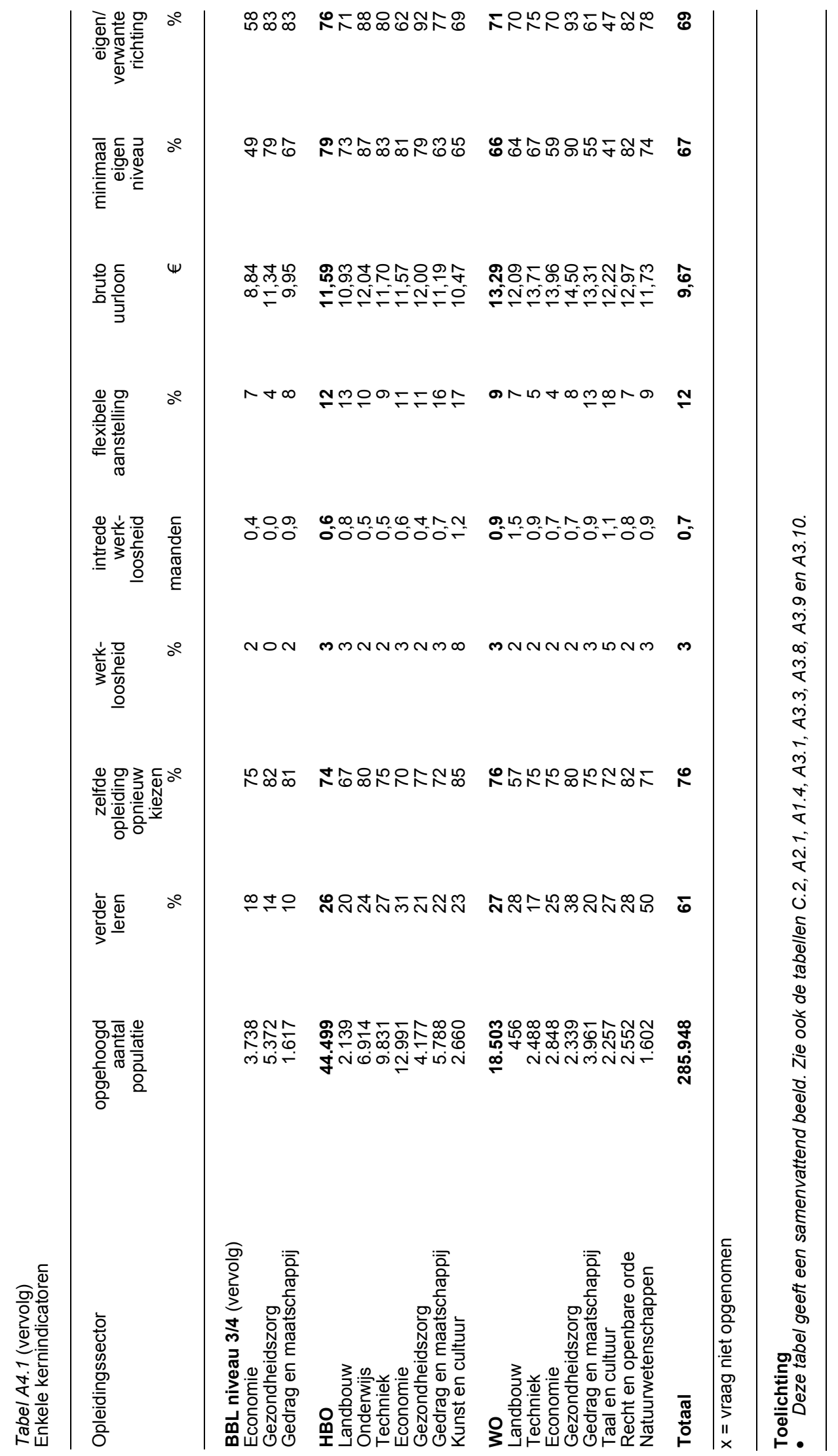



B. Tabellen per opleidingsrichting 



\section{Inhoud}

\section{Bestemming van schoolverlaters}

B1.1 De uitstroom van schoolverlaters verbijzonderd naar geslacht, etniciteit en gemiddelde leeftijd op moment van enquête

B1.2 Vooropleiding van schoolverlaters

B1.3 Bestemming van schoolverlaters

B1.4 Gevolgde opleiding opnieuw kiezen?

\section{Doorstroom naar vervolgonderwijs}

B2.1 Doorstroom van schoolverlaters naar vervolgonderwijs

B2.2 Belangrijkste opleidingen van schoolverlaters die een voltijd vervolgopleiding zijn gaan volgen

B2.3 Oordeel van schoolverlaters over de aansluiting van de afgesloten opleiding met de voltijd vervolgopleiding

B2.4 Doorstroom van schoolverlaters naar de beroepsbegeleidende leerweg

3 Intrede op de arbeidsmarkt

B3.1 Werkloosheid en gemiddelde intredewerkloosheid van schoolverlaters die zich aanbieden op de arbeidsmarkt

B3.2 Aard van het dienstverband van werkende schoolverlaters

B3.3 Percentage werkende schoolverlaters met een flexibele aanstelling

B3.4 Wijze van verkrijgen van een baan

B3.5 Belangrijkste bedrijfsgroepen waarin schoolverlaters werkzaam zijn

B3.6 Belangrijkste beroepsgroepen waarin schoolverlaters werkzaam zijn

B3.7 Grootte van de organisatie waarin schoolverlaters werkzaam zijn

B3.8 Beloning van werkende schoolverlaters

B3.9 Vereist opleidingsniveau voor de huidige functie volgens de werkgever

B3.10 Vereiste opleidingsrichting voor de huidige functie volgens de werkgever

B3.11 Gewenste en feitelijke wekelijkse arbeidsduur van werkende schoolverlaters

B3.12 Oordeel van de werkende schoolverlaters over de aansluiting tussen de afgesloten opleiding en de huidige functie

B3.13 Percentage werkende schoolverlaters dat op zoek is naar een andere baan

B3.14 Deelname aan een cursus of bedrijfsopleiding door werkende schoolverlaters

B3.15 Belangrijkste cursussen of bedrijfsopleidingen waaraan werkende schoolverlaters deelnemen

4 Kernindicatoren

B4.1 Enkele kernindicatoren 
Tabel B1.1

De uitstroom van schoolverlaters verbijzonderd naar geslacht, etniciteit en gemiddelde leeftijd op moment van enquête

\begin{tabular}{lrrr}
\hline Opleidingsrichting & vrouw & allochtoon & leeftijd \\
& $\%$ & gem.
\end{tabular}

VBO

IVBO Landbouw en natuurlijke omgeving

IVBO Bouwtechniek

IVBO Mechanische techniek

IVBO Verzorging

Landbouw en natuurlijke omgeving

Bouwtechniek

Mechanische techniek

Elektrotechniek

Motorvoertuigentechniek

Consumptieve techniek

Grafische techniek

Administratie

Verkoop

Handel

Verzorging

Uiterlijke verzorging

gem.

BOL niveau $1 / 2$

$A B$ Beveiliging

$A B$ Secretarieel

$A B$ Detailhandel/ambulante handel

$A B$ Horeca, instellingskeuken en contractcatering

BB Bouw

BB Houtbewerking en woninginrichting

BB Werktuigbouwkunde

BB Motorvoertuigen

BB Energietechniek

BB Bedrijfsadministratie

BB Beveiliging

BB Commerciee

BB Secretarieel

BB Detailhandel/ambulante handel

BB Horeca, instellingskeuken en contractcatering

BB Facilitaire dienstverlening

$B B$ Verpleging en verzorging

BB Uiterlijke verzorging

$\begin{array}{rrr}46 & 2 & 17,8 \\ 0 & 13 & 17,9 \\ 0 & 13 & 17,6 \\ 89 & 5 & 17,6 \\ 60 & 5 & 17,4 \\ 1 & 8 & 17,3 \\ 3 & 9 & 17,4 \\ 0 & 10 & 17,3 \\ 0 & 20 & 17,8 \\ 31 & 1 & 17,6 \\ 20 & 19 & 18,4 \\ 67 & 35 & 17,4 \\ 49 & 21 & 17,7 \\ 65 & 36 & 17,5 \\ 99 & 8 & 17,2 \\ 100 & 8 & 17,1\end{array}$

BOL niveau $3 / 4$

ZB Plantenteelt

ZB Veehouderij

ZB Bloemschikken

ZB Groene ruimte

ZB Laboratoriumtechniek

ZB Scheepvaart

ZB Bedrijfsadministratief

ZB Secretarieel

ZB Detailhandel/ambulante handel

ZB Verpleging en verzorging

ZB Uiterlijke verzorging

KF Plantenteelt

KF Veehouderij

KF Levensmiddelentechnologie

KF Bloemschikken

KF Dierverzorging en veterinaire ondersteuning

KF Groene ruimte

$\begin{array}{rrr}39 & 9 & 22,1 \\ 45 & 27 & 20,6 \\ 84 & 27 & 19,0 \\ 48 & 31 & 18,9 \\ 8 & 0 & 21,2 \\ 54 & 4 & 20,8 \\ 7 & 0 & 21,8 \\ 0 & 24 & 20,5 \\ 0 & 24 & 20,0 \\ 53 & 35 & 20,0 \\ 58 & 9 & 20,3 \\ 69 & 42 & 20,6 \\ 94 & 20 & 19,8 \\ 58 & 29 & 20,3 \\ 43 & 4 & 20,8 \\ 63 & 9 & 22,2 \\ 95 & 11 & 19,9 \\ 100 & 14 & 20,8\end{array}$

$\begin{array}{rrr}13 & 0 & 20,6 \\ 36 & 0 & 20,8 \\ 95 & 5 & 20,8 \\ 11 & 0 & 21,5 \\ 49 & 0 & 21,3 \\ 5 & 0 & 22,7 \\ 72 & 20 & 21,2 \\ 99 & 24 & 20,7 \\ 77 & 14 & 19,9 \\ 98 & 5 & 22,4 \\ 100 & 12 & 21,0 \\ 13 & 1 & 21,3 \\ 36 & 0 & 21,2 \\ 44 & 7 & 21,8 \\ 92 & 3 & 21,3 \\ 86 & 0 & 22,3 \\ 15 & 0 & 22,1\end{array}$


Tabel B1.1 (vervolg)

De uitstroom van schoolverlaters verbijzonderd naar geslacht, etniciteit en gemiddelde leeftijd op moment van enquête

\begin{tabular}{|c|c|c|c|}
\hline Opleidingsrichting & $\begin{array}{r}\text { vrouw } \\
\%\end{array}$ & $\begin{array}{r}\text { allochtoon } \\
\%\end{array}$ & $\begin{array}{r}\text { leeftijd } \\
\text { gem. }\end{array}$ \\
\hline
\end{tabular}

BOL niveau $3 / 4$ (vervolg)

KF Milieutoezicht

MKF Bouw

MKF Houtbewerking en woninginichting

MKF Grond-, water- en wegenbouw

MKF Beschermings- en afwerkingstechnieken

MKF Reclame, presentatie en communicatie

MKF Werktuigbouwkunde

MKF Motorvoertuigen

MKF Energie- en informatietechniek

MKF Energietechniek

MKF Informatietechniek

MKF Graf. techn, communicatie, audiovisueel en multimedia

MKF Mode en kleding (realisatie)

MKF Laboratoriumtechniek

MKF Procestechniek

MKF Scheepvaart

MKF Transport en logistiek

MKF Bedrijfsadministratief

MKF Commercieel

MKF Economisch-juridisch

MKF Logistiek

MKF Secretarieel

MKF Detailhandel/ambulante handel

MKF Groothandel/distributie

MKF Horeca, instellingskeuken en contractcatering

MKF Toerisme, recreatie en reizen

MKF Assistenten gezondheidszorg

MKF Facilitaire dienstverlening

MKF Sport en bewegen

MKF Verpleging en verzorging

MKF Maatschappelijke dienstverlening

MKF Sociaal-cultureel werker

MKF Sociaal-pedagogisch werk algemeen

MKF Sociaal-juridisch werk

$\begin{array}{rrr}23 & 0 & 22,0 \\ 8 & 6 & 22,1 \\ 48 & 6 & 23,5 \\ 0 & 8 & 22,7 \\ 44 & 15 & 22,1 \\ 82 & 3 & 22,1 \\ 0 & 11 & 22,5 \\ 4 & 7 & 21,7 \\ 2 & 7 & 23,5 \\ 0 & 5 & 21,5 \\ 1 & 8 & 27,5 \\ 38 & 11 & 22,8 \\ 100 & 9 & 21,9 \\ 49 & 10 & 22,3 \\ 6 & 4 & 22,4 \\ 2 & 6 & 22,7 \\ 18 & 6 & 22,6 \\ 45 & 19 & 21,2 \\ 58 & 24 & 21,5 \\ 58 & 41 & 21,5 \\ 35 & 14 & 21,2 \\ 100 & 15 & 20,8 \\ 54 & 11 & 21,0 \\ 25 & 10 & 20,9 \\ 53 & 8 & 22,1 \\ 92 & 11 & 22,2 \\ 99 & 14 & 21,2 \\ 52 & 8 & 21,2 \\ 38 & 7 & 22,7 \\ 92 & 1 & 22,9 \\ 88 & 12 & 21,5 \\ 70 & 29 & 21,9 \\ 93 & 7 & 22,1 \\ 92 & 47 & 21,2\end{array}$

BBL niveau $1 / 2$

AB Procestechniek

AB Beveiliging

AB Detailhandel/ambulante handel

$A B$ Horeca, instellingskeuken en contractcatering

BB Plantenteelt

BB Bloemschikken

BB Groene ruimte

BB Bouw

BB Houtbewerking en woninginrichting

BB Grond-, water en wegenbouw

BB Beschermings- en afwerkingstechnieken

BB Constructie-, plaatwerken/pijpenbewerken

BB Machinebankwerken/verspanen

BB Montage/onderhoud/operationele techniek

BB Motorvoertuigen

BB Energie- en informatietechniek

BB Installatie-, service- en onderhoudstechniek

BB Graf. techn, communicatie, audiovisueel en multimedia

BB Wegvervoer

BB Detailhandel/ambulante handel

$\begin{array}{rrr}10 & 9 & 30,9 \\ 56 & 30 & 36,4 \\ 83 & 5 & 20,0 \\ 30 & 15 & 26,0 \\ 21 & 3 & 20,9 \\ 100 & 4 & 21,1 \\ 5 & 4 & 30,1 \\ 2 & 4 & 22,4 \\ 0 & 0 & 20,4 \\ 0 & 24 & 25,0 \\ 7 & 0 & 25,4 \\ 2 & 6 & 21,3 \\ 0 & 4 & 20,9 \\ 0 & 23 & 23,8 \\ 0 & 11 & 22,9 \\ 0 & 13 & 23,7 \\ 4 & 0 & 24,6 \\ 15 & 17 & 23,9 \\ 4 & 1 & 20,6 \\ 87 & 2 & 21,4\end{array}$


Tabel B1.1 (vervolg)

De uitstroom van schoolverlaters verbijzonderd naar geslacht, etniciteit en gemiddelde leeftijd op moment van enquête

\begin{tabular}{lrrr}
\hline Opleidingsrichting & vrouw & allochtoon & leeftijd \\
& $\%$ & $\%$ & gem.
\end{tabular}

BBL niveau $1 / 2$ (vervolg)

BB Opslag/magazijn

BB Horeca, instellingskeuken en contractcatering

BB Facilitaire dienstverlening

$B B$ Verpleging en verzorging

BB Uiterlijke verzorging

$\begin{array}{rrr}14 & 18 & 35,9 \\ 27 & 8 & 20,6 \\ 98 & 22 & 30,7 \\ 96 & 22 & 33,6 \\ 100 & 16 & 20,0\end{array}$

BBL niveau $3 / 4$

ZB Bloemschikken

ZB Groene ruimte

ZB Bouw

ZB Grond-, water- en wegenbouw

ZB Beschermings- en afwerkingstechnieken

ZB Motorvoertuigen

ZB Beheer, ontwerp en management (instal. techn)

ZB Installatie-, service- en onderhoudstechniek

ZB Procestechniek

ZB Detailhandel/ambulante handel

ZB Horeca, instellingskeuken en contractcatering

ZB Verpleging en verzorging

ZB Uiterlijke verzorging

ZB Sociaal-pedagogisch werk

MKF Detailhandel/ambulante handel

MKF Horeca, instellingskeuken en contractcatering

MKF Verpleging en verzorging

MKF Sociaal-pedagogisch werk

Specialist Energietechniek

Specialist Verpleging en verzorging

$\begin{array}{rrr}87 & 0 & 22,2 \\ 2 & 3 & 26,8 \\ 0 & 3 & 22,4 \\ 1 & 2 & 23,4 \\ 2 & 0 & 26,4 \\ 0 & 19 & 26,0 \\ 1 & 0 & 31,4 \\ 0 & 6 & 25,7 \\ 0 & 5 & 31,1 \\ 75 & 3 & 22,5 \\ 27 & 2 & 22,2 \\ 94 & 9 & 33,8 \\ 100 & 7 & 21,9 \\ 99 & 16 & 31,6 \\ 56 & 4 & 25,0 \\ 45 & 5 & 21,4 \\ 83 & 8 & 31,8 \\ 71 & 6 & 36,6 \\ 17 & 4 & 30,4 \\ 96 & 5 & 38,3\end{array}$

Zie ook toelichting bladzijde 5 


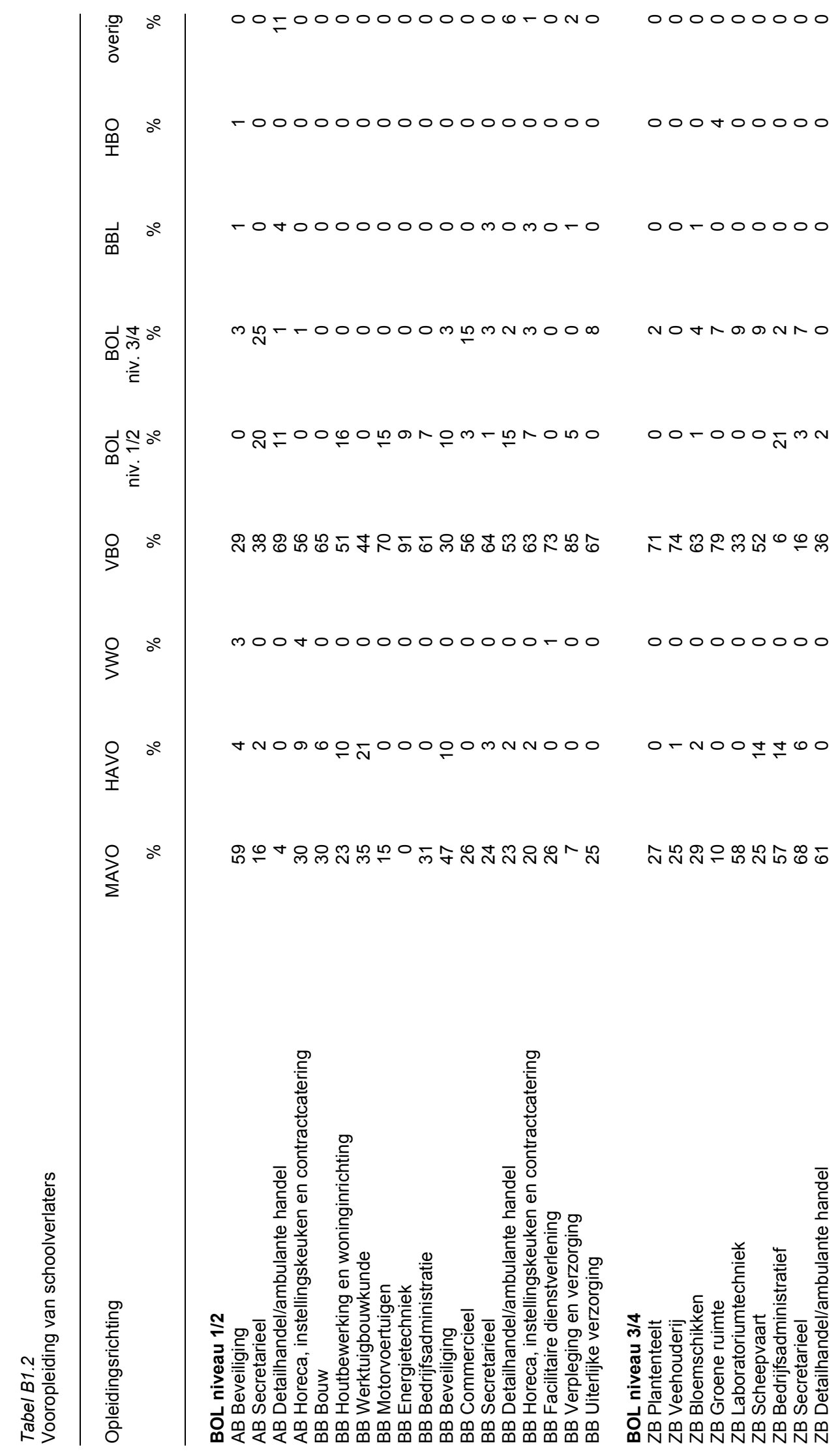




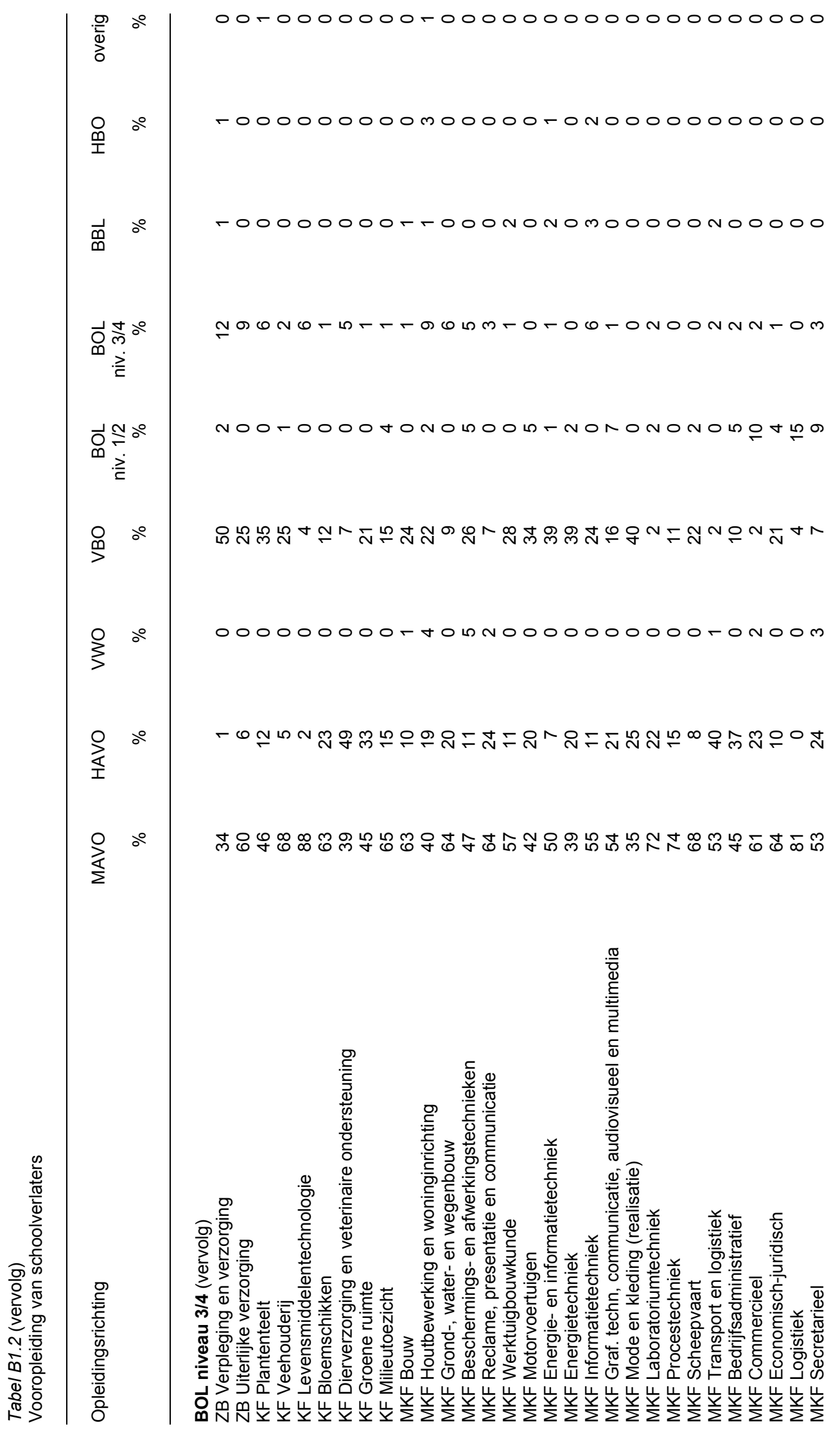




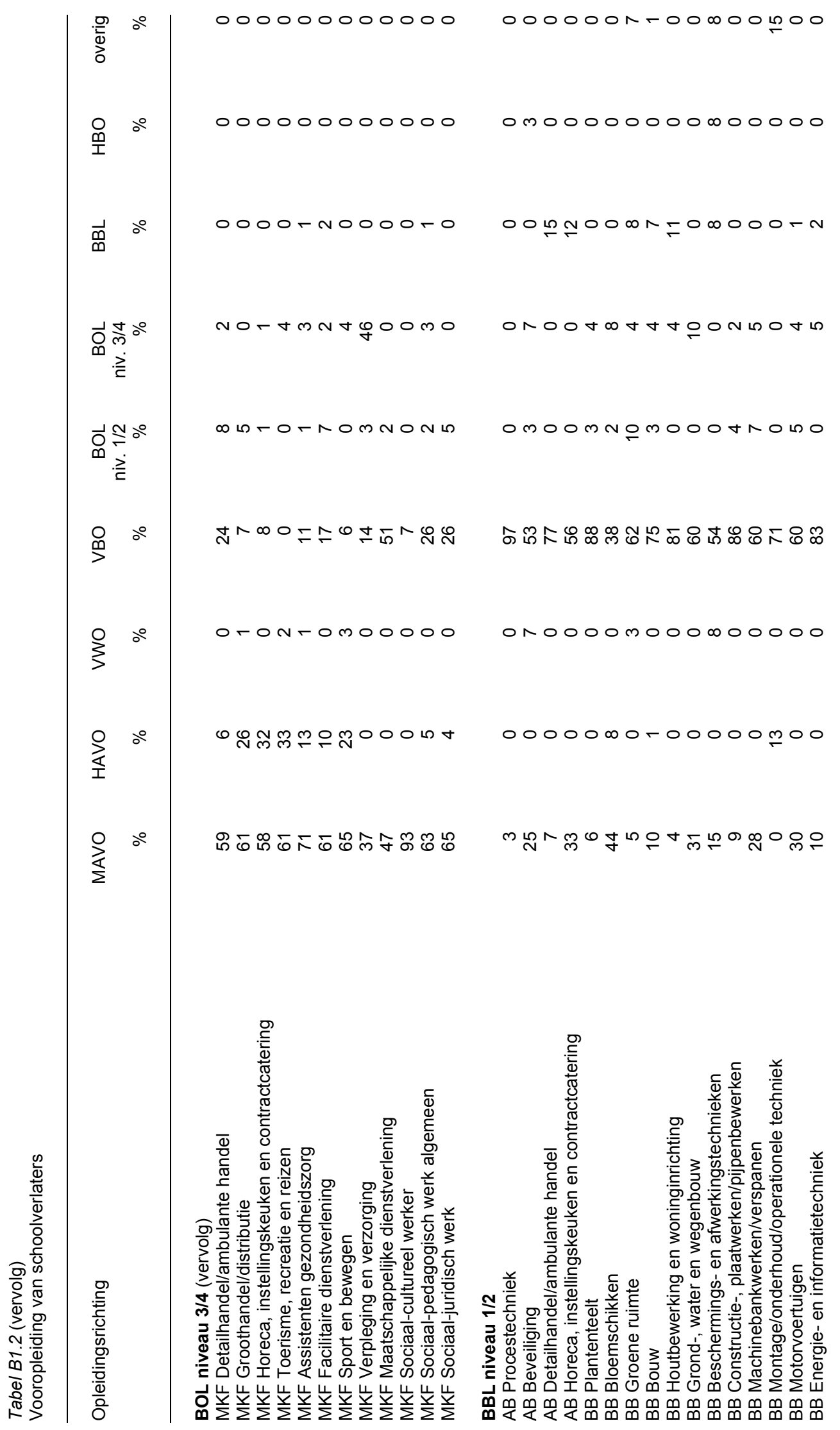




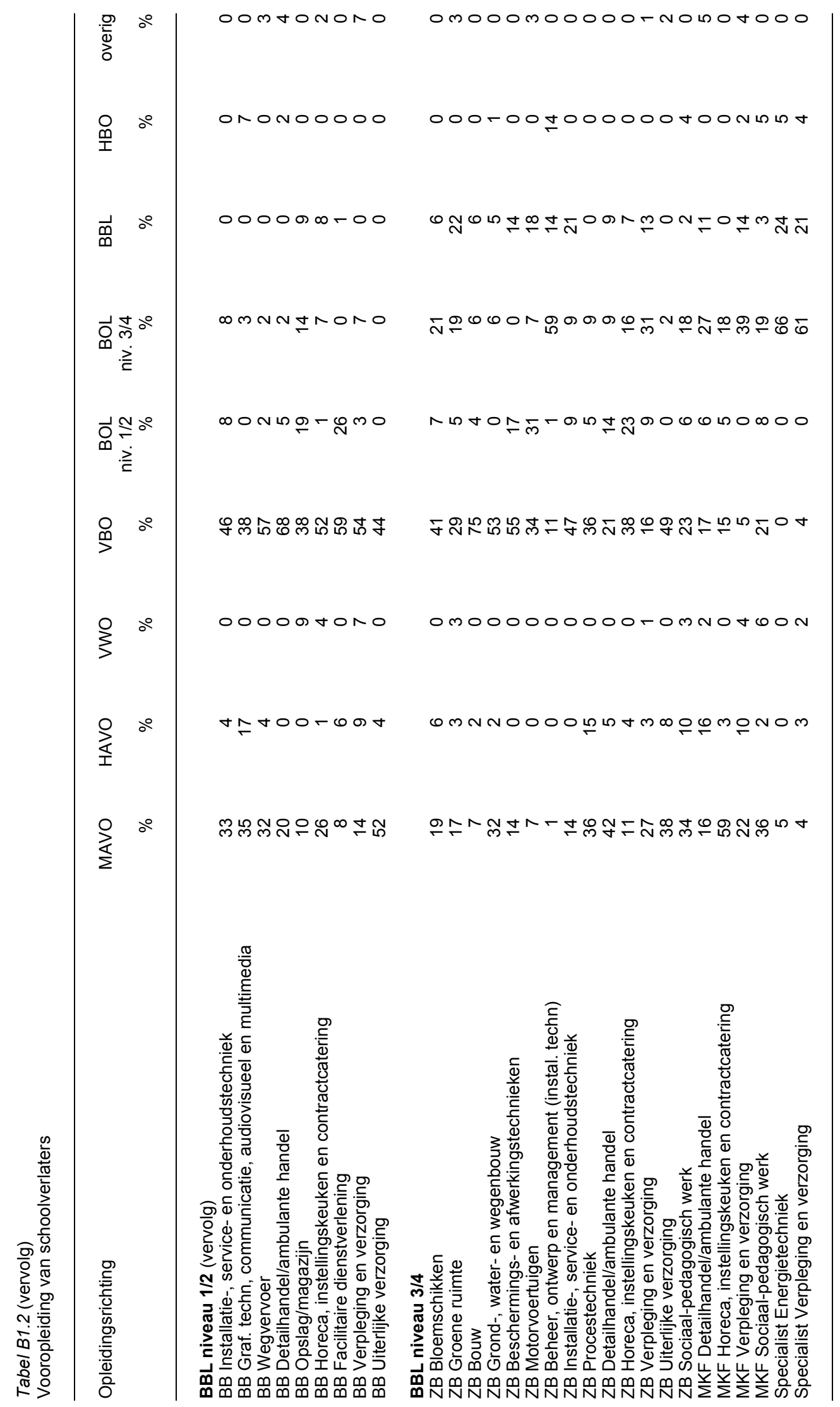


Tabel B1.3

Bestemming van schoolverlaters

\begin{tabular}{|c|c|c|c|c|c|}
\hline Opleidingsrichting & $\begin{array}{r}\text { studie } \\
\%\end{array}$ & $\begin{array}{r}\text { BBL } \\
\%\end{array}$ & $\begin{array}{r}\text { betaald } \\
\text { werk } \\
\%\end{array}$ & $\begin{array}{r}\text { werk- } \\
\text { loos } \\
\%\end{array}$ & $\begin{array}{r}\text { anders } \\
\%\end{array}$ \\
\hline \multicolumn{6}{|l|}{ VBO } \\
\hline IVBO Landbouw en natuurlijke omgeving & 28 & 26 & 40 & 2 & \\
\hline IVBO Bouwtechniek & 0 & 64 & 33 & 1 & 1 \\
\hline IVBO Mechanische techniek & 14 & 55 & 31 & 0 & 0 \\
\hline IVBO Verzorging & 64 & 9 & 20 & 7 & 0 \\
\hline Landbouw en natuurlijke omgeving & 51 & 13 & 29 & 3 & 4 \\
\hline Bouwtechniek & 29 & 39 & 26 & 2 & 5 \\
\hline Mechanische techniek & 34 & 31 & 31 & 0 & \\
\hline Elektrotechniek & 61 & 9 & 30 & 0 & 0 \\
\hline Motorvoertuigentechniek & 9 & 53 & 36 & 0 & 2 \\
\hline Consumptieve techniek & 25 & 43 & 29 & 0 & \\
\hline Grafische techniek & 50 & 4 & 34 & 9 & 2 \\
\hline Administratie & 59 & 13 & 21 & 4 & 4 \\
\hline Verkoop & 48 & 12 & 30 & 0 & \\
\hline Handel & 62 & 2 & 34 & 1 & 2 \\
\hline Verzorging & 66 & 10 & 18 & 1 & 5 \\
\hline Uiterlijke verzorging & 41 & 23 & 29 & 1 & \\
\hline \multicolumn{6}{|l|}{ BOL niveau $1 / 2$} \\
\hline AB Beveiliging & 16 & 0 & 68 & 6 & 9 \\
\hline AB Secretarieel & 47 & 0 & 29 & 9 & 15 \\
\hline AB Detailhandel/ambulante handel & 31 & 7 & 48 & 7 & 6 \\
\hline AB Horeca, instellingskeuken en contractcatering & 44 & 7 & 42 & 3 & 3 \\
\hline BB Bouw & 11 & 15 & 63 & 6 & \\
\hline BB Houtbewerking en woninginrichting & 31 & 4 & 65 & 0 & 0 \\
\hline BB Werktuigbouwkunde & 28 & 0 & 70 & 0 & 2 \\
\hline BB Motorvoertuigen & 5 & 27 & 68 & 0 & \\
\hline BB Energietechniek & 22 & 22 & 55 & 0 & 0 \\
\hline BB Bedrijfsadministratie & 37 & 4 & 55 & 2 & 2 \\
\hline BB Beveiliging & 13 & 0 & 80 & 0 & 8 \\
\hline BB Commercieel & 35 & 9 & 56 & 0 & \\
\hline BB Secretarieel & 34 & 1 & 56 & 3 & \\
\hline BB Detailhandel/ambulante handel & 23 & 11 & 60 & 6 & 0 \\
\hline BB Horeca, instellingskeuken en contractcatering & 13 & 11 & 66 & 2 & \\
\hline BB Facilitaire dienstverlening & 39 & 6 & 53 & 2 & 0 \\
\hline BB Verpleging en verzorging & 34 & 18 & 41 & 4 & 3 \\
\hline BB Uiterlijke verzorging & 12 & 0 & 82 & 0 & 6 \\
\hline
\end{tabular}

BOL niveau $3 / 4$

ZB Plantenteelt

ZB Veehouderij

ZB Bloemschikken

ZB Groene ruimte

ZB Laboratoriumtechniek

ZB Scheepvaart

ZB Bedrijfsadministratief

ZB Secretarieel

ZB Detailhandel/ambulante handel

$Z B$ Verpleging en verzorging

ZB Uiterlijke verzorging

KF Plantenteelt

KF Veehouderij

KF Levensmiddelentechnologie

KF Bloemschikken

KF Dierverzorging en veterinaire ondersteuning

KF Groene ruimte

KF Milieutoezicht

$\begin{array}{rlllr}17 & 6 & 76 & 0 & 2 \\ 8 & 2 & 85 & 4 & 1 \\ 11 & 7 & 80 & 2 & 0 \\ 7 & 0 & 92 & 0 & 2 \\ 47 & 0 & 49 & 0 & 4 \\ 5 & 0 & 86 & 0 & 10 \\ 21 & 9 & 65 & 2 & 4 \\ 16 & 1 & 80 & 1 & 2 \\ 45 & 2 & 46 & 0 & 7 \\ 18 & 8 & 71 & 0 & 3 \\ 5 & 1 & 88 & 0 & 5 \\ 40 & 0 & 50 & 1 & 9 \\ 34 & 3 & 61 & 0 & 2 \\ 47 & 0 & 49 & 0 & 4 \\ 17 & 1 & 79 & 1 & 1 \\ 23 & 0 & 77 & 0 & 0 \\ 51 & 0 & 45 & 0 & 5 \\ 42 & 2 & 56 & 0 & 0\end{array}$


Tabel B1.3 (vervolg)

Bestemming van schoolverlaters

\begin{tabular}{|c|c|c|c|c|c|}
\hline Opleidingsrichting & $\begin{array}{r}\text { studie } \\
\%\end{array}$ & $\begin{array}{r}\text { BBL } \\
\%\end{array}$ & $\begin{array}{r}\text { betaald } \\
\text { werk } \\
\%\end{array}$ & $\begin{array}{r}\text { werk- } \\
\text { loos } \\
\%\end{array}$ & $\begin{array}{r}\text { anders } \\
\%\end{array}$ \\
\hline
\end{tabular}

BOL niveau 3/4 (vervolg)

MKF Bouw

MKF Houtbewerking en woninginrichting

MKF Grond-, water- en wegenbouw

MKF Beschermings- en afwerkingstechnieken

MKF Reclame, presentatie en communicatie

MKF Werktuigbouwkunde

MKF Motorvoertuigen

MKF Energie- en informatietechniek

MKF Energietechniek

MKF Informatietechniek

MKF Graf. techn, communicatie, audiovisueel en multimedia

MKF Mode en kleding (realisatie)

MKF Laboratoriumtechniek

MKF Procestechniek

MKF Scheepvaart

MKF Transport en logistiek

MKF Bedrijfsadministratief

MKF Commercieel

MKF Economisch-juridisch

MKF Logistiek

MKF Secretarieel

MKF Detailhandel/ambulante handel

MKF Groothandel/distributie

MKF Horeca, instellingskeuken en contractcatering

MKF Toerisme, recreatie en reizen

MKF Assistenten gezondheidszorg

MKF Facilitaire dienstverlening

MKF Sport en bewegen

MKF Verpleging en verzorging

MKF Maatschappelijke dienstverlening

MKF Sociaal-cultureel werker

MKF Sociaal-pedagogisch werk algemeen

MKF Sociaal-juridisch werk

$\begin{array}{rrrrr}41 & 0 & 57 & 1 & 1 \\ 21 & 0 & 74 & 2 & 3 \\ 33 & 0 & 63 & 0 & 4 \\ 20 & 0 & 75 & 5 & 0 \\ 28 & 0 & 69 & 2 & 2 \\ 41 & 0 & 56 & 0 & 3 \\ 36 & 0 & 59 & 0 & 4 \\ 40 & 1 & 59 & 0 & 0 \\ 64 & 0 & 33 & 0 & 2 \\ 29 & 0 & 71 & 0 & 0 \\ 26 & 5 & 65 & 3 & 1 \\ 22 & 0 & 73 & 5 & 0 \\ 41 & 3 & 53 & 1 & 1 \\ 35 & 0 & 65 & 0 & 0 \\ 43 & 0 & 55 & 2 & 0 \\ 30 & 0 & 68 & 0 & 2 \\ 48 & 0 & 48 & 0 & 4 \\ 35 & 0 & 62 & 0 & 3 \\ 60 & 0 & 32 & 4 & 4 \\ 30 & 0 & 56 & 0 & 14 \\ 23 & 0 & 73 & 3 & 0 \\ 36 & 3 & 58 & 0 & 2 \\ 51 & 0 & 47 & 0 & 1 \\ 33 & 0 & 65 & 0 & 2 \\ 25 & 0 & 71 & 2 & 2 \\ 18 & 2 & 78 & 1 & 1 \\ 32 & 2 & 66 & 0 & 0 \\ 42 & 1 & 51 & 0 & 6 \\ 6 & 4 & 89 & 0 & 2 \\ 56 & 0 & 35 & 9 & 0 \\ 61 & 0 & 26 & 0 & 13 \\ 36 & 2 & 58 & 1 & 4 \\ 39 & 3 & 50 & 1 & 7\end{array}$

BBL niveau $1 / 2$

AB Procestechniek

$A B$ Beveiliging

AB Detailhandel/ambulante handel

$A B$ Horeca, instellingskeuken en contractcatering

BB Plantenteelt

BB Bloemschikken

BB Groene ruimte

BB Bouw

BB Houtbewerking en woninginrichting

BB Grond-, water en wegenbouw

BB Beschermings- en afwerkingstechnieken

BB Constructie-, plaatwerken/pijpenbewerken

BB Machinebankwerken/verspanen

BB Montage/onderhoud/operationele techniek

BB Motorvoertuigen

BB Energie- en informatietechniek

BB Installatie-, service- en onderhoudstechniek

BB Graf. techn, communicatie, audiovisueel en multimedia

BB Wegvervoer

BB Detailhandel/ambulante handel

BB Opslag/magazijn

$\begin{array}{rrrrr}0 & 2 & 86 & 0 & 11 \\ 0 & 0 & 89 & 8 & 3 \\ 5 & 5 & 77 & 1 & 11 \\ 5 & 3 & 67 & 3 & 22 \\ 0 & 3 & 97 & 0 & 0 \\ 2 & 4 & 72 & 6 & 16 \\ 0 & 3 & 94 & 0 & 3 \\ 3 & 14 & 78 & 1 & 4 \\ 0 & 4 & 91 & 0 & 5 \\ 8 & 8 & 68 & 16 & 0 \\ 0 & 7 & 65 & 0 & 28 \\ 5 & 15 & 74 & 0 & 6 \\ 7 & 13 & 73 & 0 & 7 \\ 0 & 0 & 100 & 0 & 0 \\ 0 & 11 & 85 & 4 & 1 \\ 5 & 10 & 59 & 0 & 26 \\ 0 & 5 & 86 & 0 & 9 \\ 7 & 0 & 93 & 0 & 0 \\ 2 & 5 & 92 & 0 & 1 \\ 3 & 7 & 86 & 0 & 4 \\ 0 & 0 & 95 & 5 & 0\end{array}$


Tabel B1.3 (vervolg)

Bestemming van schoolverlaters

\begin{tabular}{lrrrrr} 
Opleidingsrichting & studie & BBL betaald & $\begin{array}{r}\text { werk- } \\
\text { werk } \\
\text { loos }\end{array}$ & $\%$ & $\%$ \\
\hline
\end{tabular}

BBL niveau $\mathbf{1 / 2}$ (vervolg)

BB Horeca, instellingskeuken en contractcatering

BB Facilitaire dienstverlening

$B B$ Verpleging en verzorging

BB Uiterlijke verzorging

$\begin{array}{rrrrr}15 & 26 & 55 & 0 & 3 \\ 0 & 12 & 88 & 0 & 0 \\ 0 & 19 & 78 & 1 & 3 \\ 0 & 0 & 100 & 0 & 0\end{array}$

BBL niveau $3 / 4$

ZB Bloemschikken

ZB Groene ruimte

ZB Bouw

ZB Grond-, water- en wegenbouw

ZB Beschermings- en afwerkingstechnieken

ZB Motorvoertuigen

ZB Beheer, ontwerp en management (instal. techn)

ZB Installatie-, service- en onderhoudstechniek

ZB Procestechniek

ZB Detailhandel/ambulante handel

ZB Horeca, instellingskeuken en contractcatering

$Z B$ Verpleging en verzorging

ZB Uiterlijke verzorging

ZB Sociaal-pedagogisch werk

MKF Detailhandel/ambulante handel

MKF Horeca, instellingskeuken en contractcatering

MKF Verpleging en verzorging

MKF Sociaal-pedagogisch werk

Specialist Energietechniek

Specialist Verpleging en verzorging 
Tabel B1.4

Gevolgde opleiding opnieuw kiezen?

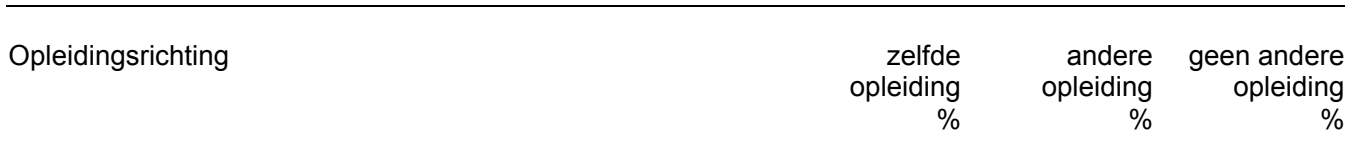

BOL niveau $1 / 2$

$\mathrm{AB}$ Beveiliging

$A B$ Secretarieel

$A B$ Detailhandel/ambulante handel

$A B$ Horeca, instellingskeuken en contractcatering

BB Bouw

BB Houtbewerking en woninginrichting

BB Werktuigbouwkunde

BB Motorvoertuigen

BB Energietechniek

BB Bedrijfsadministratie

BB Beveiliging

BB Commercieel

BB Secretarieel

BB Detailhandel/ambulante handel

BB Horeca, instellingskeuken en contractcatering

BB Facilitaire dienstverlening

BB Verpleging en verzorging

BB Uiterlijke verzorging

$\begin{array}{rrr}76 & 17 & 8 \\ 64 & 18 & 18 \\ 73 & 13 & 13 \\ 65 & 10 & 24 \\ 78 & 22 & 0 \\ 94 & 6 & 0 \\ 85 & 8 & 8 \\ 65 & 25 & 10 \\ 45 & 36 & 18 \\ 71 & 21 & 8 \\ 89 & 11 & 0 \\ 74 & 15 & 11 \\ 69 & 28 & 3 \\ 52 & 35 & 13 \\ 49 & 40 & 11 \\ 56 & 39 & 6 \\ 74 & 20 & 7 \\ 80 & 20 & 0\end{array}$

BOL niveau $3 / 4$

ZB Plantenteelt

ZB Veehouderij

ZB Bloemschikken

ZB Groene ruimte

ZB Laboratoriumtechniek

ZB Scheepvaart

ZB Bedrijfsadministratief

ZB Secretarieel

ZB Detailhandel/ambulante handel

ZB Verpleging en verzorging

ZB Uiterlijke verzorging

KF Plantenteelt

KF Veehouderij

KF Levensmiddelentechnologie

KF Bloemschikken

KF Dierverzorging en veterinaire ondersteuning

KF Groene ruimte

KF Milieutoezicht

MKF Bouw

MKF Houtbewerking en woninginrichting

MKF Grond-, water- en wegenbouw

MKF Beschermings- en afwerkingstechnieken

MKF Reclame, presentatie en communicatie

MKF Werktuigbouwkunde

MKF Motorvoertuigen

MKF Energie- en informatietechniek

MKF Energietechniek

MKF Informatietechniek

MKF Graf. techn, communicatie, audiovisueel en multimedia

MKF Mode en kleding (realisatie)

MKF Laboratoriumtechniek

MKF Procestechniek

MKF Scheepvaart

MKF Transport en logistiek

MKF Bedrijfsadministratief

MKF Commercieel

MKF Economisch-juridisch

$\begin{array}{lrl}68 & 32 & 0 \\ 63 & 31 & 6 \\ 77 & 21 & 1 \\ 89 & 11 & 0 \\ 66 & 34 & 0 \\ 76 & 24 & 0 \\ 77 & 18 & 5 \\ 87 & 13 & 0 \\ 87 & 13 & 0 \\ 79 & 20 & 1 \\ 81 & 19 & 0 \\ 60 & 38 & 1 \\ 75 & 23 & 3 \\ 96 & 4 & 0 \\ 62 & 36 & 1 \\ 89 & 11 & 0 \\ 81 & 18 & 0 \\ 71 & 29 & 0 \\ 81 & 18 & 1 \\ 88 & 10 & 3 \\ 98 & 2 & 0 \\ 80 & 20 & 0 \\ 85 & 15 & 0 \\ 80 & 20 & 0 \\ 68 & 32 & 0 \\ 78 & 22 & 0 \\ 38 & 63 & 0 \\ 91 & 6 & 3 \\ 84 & 16 & 0 \\ 83 & 17 & 0 \\ 78 & 21 & 1 \\ 95 & 5 & 0 \\ 89 & 11 & 0 \\ 74 & 25 & 2 \\ 71 & 29 & 0 \\ 73 & 27 & 0 \\ 64 & 33 & 3\end{array}$


Tabel B1.4 (vervolg)

Gevolgde opleiding opnieuw kiezen?

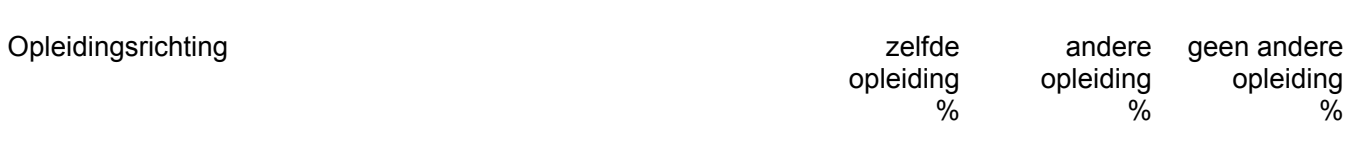

BOL niveau $3 / 4$ (vervolg)

MKF Logistiek

MKF Secretarieel

MKF Detailhandel/ambulante handel

MKF Groothandel/distributie

MKF Horeca, instellingskeuken en contractcatering

MKF Toerisme, recreatie en reizen

MKF Assistenten gezondheidszorg

MKF Facilitaire dienstverlening

MKF Sport en bewegen

MKF Verpleging en verzorging

MKF Maatschappelijke dienstverlening

MKF Sociaal-cultureel werker

MKF Sociaal-pedagogisch werk algemeen

MKF Sociaal-juridisch werk

$\begin{array}{lrl}92 & 8 & 0 \\ 66 & 32 & 2 \\ 67 & 31 & 2 \\ 71 & 26 & 3 \\ 69 & 30 & 1 \\ 84 & 16 & 0 \\ 88 & 11 & 0 \\ 68 & 30 & 2 \\ 90 & 9 & 1 \\ 74 & 26 & 0 \\ 68 & 32 & 0 \\ 74 & 26 & 0 \\ 85 & 13 & 1 \\ 89 & 11 & 0\end{array}$

BBL niveau $1 / 2$

AB Procestechniek

$A B$ Beveiliging

$A B$ Detailhandel/ambulante handel

$A B$ Horeca, instellingskeuken en contractcatering

BB Plantenteelt

BB Bloemschikken

BB Groene ruimte

BB Bouw

BB Houtbewerking en woninginrichting

BB Grond-, water en wegenbouw

BB Beschermings- en afwerkingstechnieken

BB Constructie-, plaatwerken/pijpenbewerken

BB Machinebankwerken/verspanen

BB Montage/onderhoud/operationele techniek

BB Motorvoertuigen

BB Energie- en informatietechniek

BB Installatie-, service- en onderhoudstechniek

BB Graf. techn, communicatie, audiovisueel en multimedia

BB Wegvervoer

BB Detailhandel/ambulante handel

BB Opslag/magazijn

BB Horeca, instellingskeuken en contractcatering

BB Facilitaire dienstverlening

$B B$ Verpleging en verzorging

BB Uiterlijke verzorging

$\begin{array}{rrr}82 & 9 & 9 \\ 89 & 0 & 11 \\ 57 & 25 & 18 \\ 65 & 30 & 5 \\ 87 & 7 & 6 \\ 77 & 23 & 0 \\ 91 & 5 & 4 \\ 81 & 9 & 9 \\ 70 & 26 & 4 \\ 60 & 30 & 10 \\ 78 & 11 & 11 \\ 81 & 15 & 5 \\ 75 & 25 & 0 \\ 85 & 0 & 14 \\ 71 & 29 & 0 \\ 58 & 24 & 18 \\ 79 & 21 & 0 \\ 68 & 24 & 8 \\ 81 & 13 & 5 \\ 65 & 20 & 15 \\ 85 & 10 & 5 \\ 77 & 17 & 6 \\ 68 & 32 & 0 \\ 86 & 10 & 3 \\ 96 & 4 & 0\end{array}$

$B B L$ niveau $3 / 4$

ZB Bloemschikken

ZB Groene ruimte

ZB Bouw

ZB Grond-, water- en wegenbouw

ZB Beschermings- en afwerkingstechnieken

ZB Motorvoertuigen

ZB Beheer, ontwerp en management (instal. techn)

ZB Installatie-, service- en onderhoudstechniek

ZB Procestechniek

ZB Detailhandel/ambulante handel

ZB Horeca, instellingskeuken en contractcatering

$\begin{array}{rrr}76 & 20 & 4 \\ 90 & 4 & 6 \\ 94 & 6 & 0 \\ 70 & 24 & 6 \\ 100 & 0 & 0 \\ 87 & 13 & 0 \\ 87 & 13 & 0 \\ 88 & 12 & 0 \\ 65 & 25 & 10 \\ 75 & 21 & 3 \\ 77 & 19 & 4\end{array}$


Tabel B1.4 (vervolg)

Gevolgde opleiding opnieuw kiezen?

Opleidingsrichting

zelfde

andere

geen andere

opleiding

opleiding

opleiding

$\% \quad \%$

BBL niveau 3/4 (vervolg)

ZB Verpleging en verzorging

ZB Uiterlijke verzorging

ZB Sociaal-pedagogisch werk

MKF Detailhandel/ambulante handel

MKF Horeca, instellingskeuken en contractcatering

MKF Verpleging en verzorging

MKF Sociaal-pedagogisch werk

Specialist Energietechniek

Specialist Verpleging en verzorging

$\begin{array}{lrl}85 & 12 & 3 \\ 73 & 27 & 0 \\ 81 & 18 & 1 \\ 67 & 25 & 8 \\ 78 & 16 & 6 \\ 79 & 21 & 0 \\ 85 & 15 & 0 \\ 83 & 17 & 0 \\ 93 & 4 & 3\end{array}$




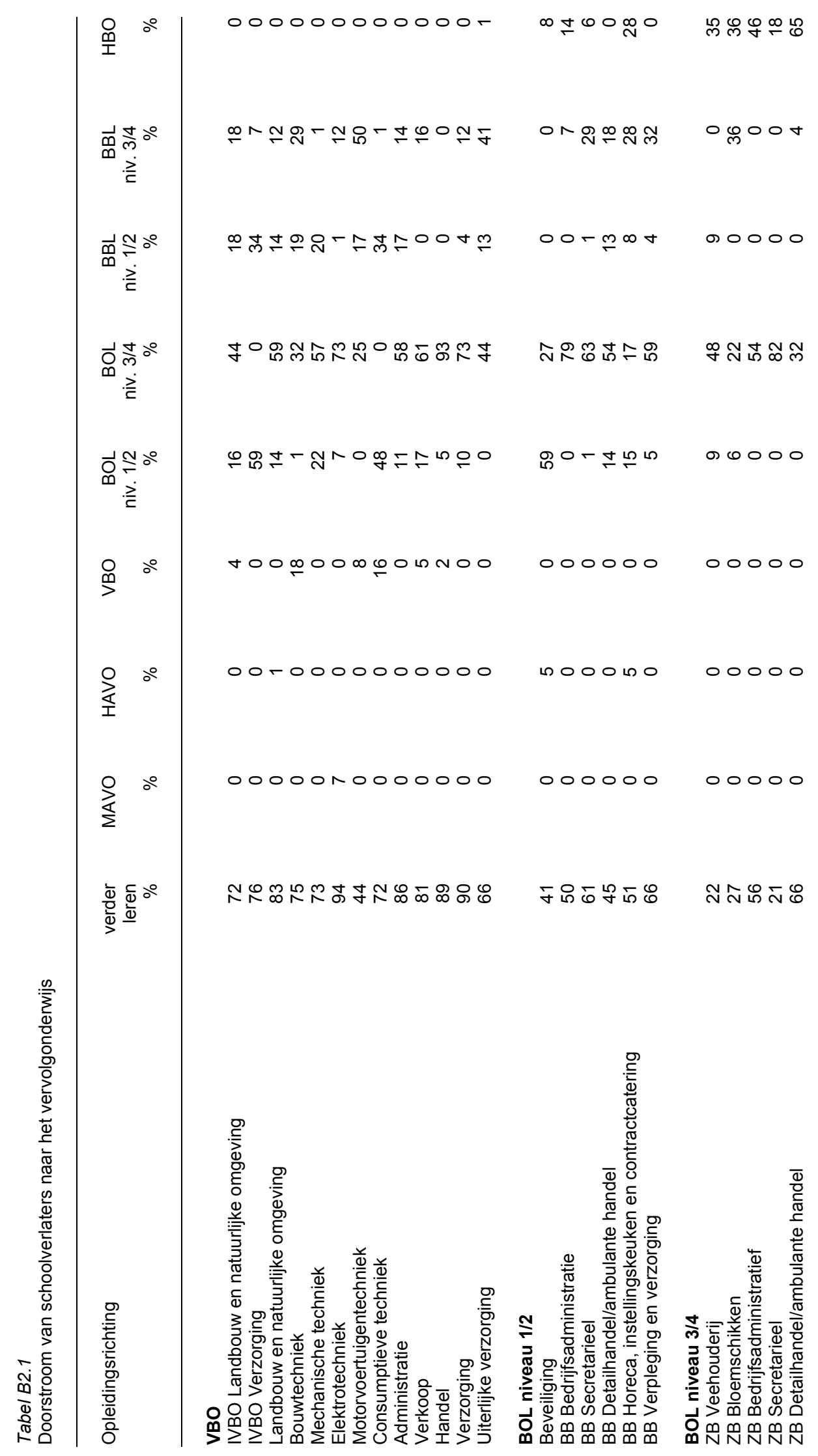




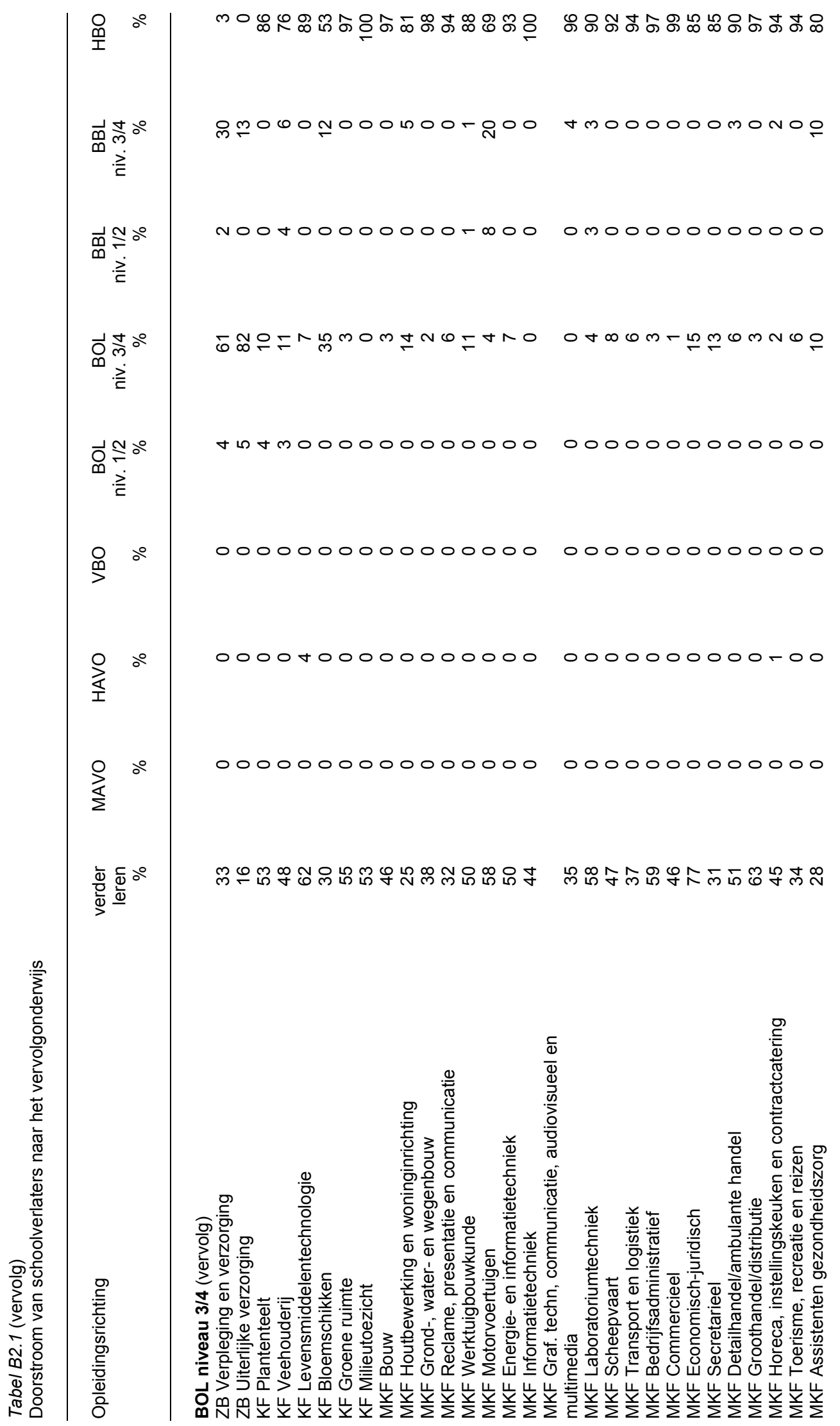




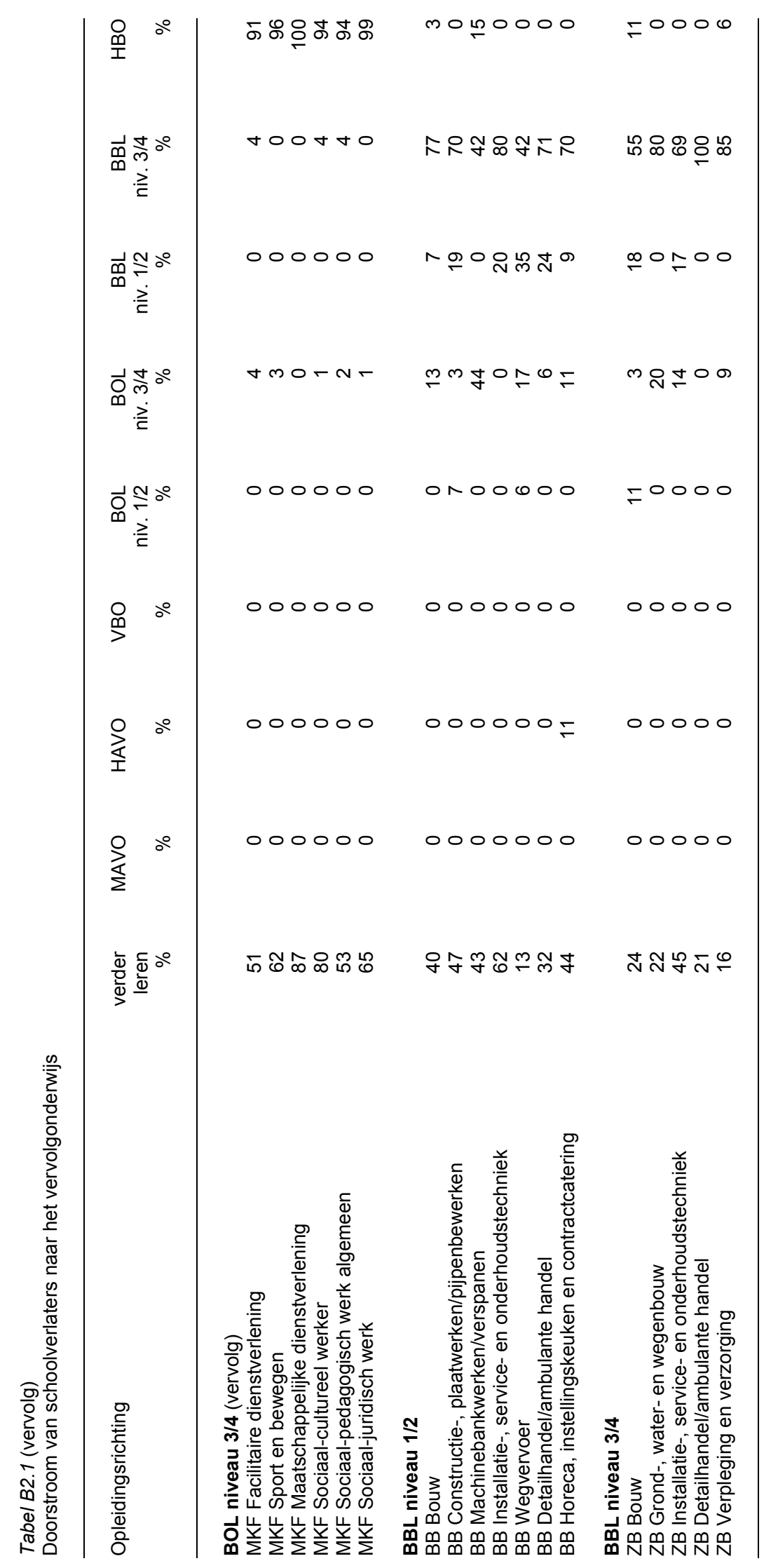


Tabel B2.2

Belangrijkste opleidingen van schoolverlaters die een voltijd vervolgopleiding zijn gaan volgen

IVBO Verzorging

BOL BB Helpende (verpleging en verzorging) 31

BBL BB Banketbakker

BBL BB Helpende (verpleging en verzorging)

VBO Mechanische techniek

BOL MKF Werktuigbouwkunde

VBO Elektrotechniek

BOL MKF Elektrotechnische installatietechniek

VBO Motorvoertuigentechniek

BBL MKF Techniek

VBO Consumptieve techniek

BOL BB Kok

VMBO Zorg en Welzijn

BOL BB Horeca, instellingskeuken en contractcatering

BBL BB Horeca, instellingskeuken en contractcatering

VBO Administratie

BOL MKF Economie

VBO Verkoop

BOL ZB Detailhandel/ambulante handel

VBO Handel

BOL MKF Sociaal-pedagogisch werk 11

BOL ZB Toerisme, recreatie en reizen $\quad 10$

BOL MKF Administratief-juridisch medewerker - openbaar bestuur 10

BOL MKF Ondernemer/manager detailhandel $\quad 10$

VBO Verzorging

BOL ZB Verzorgende

BOL MKF Sociaal-pedagogisch werk

BOL ZB Sociaal-pedagogisch werk

VBO Uiterlijke verzorging

BOL ZB Schoonheidsspecialist

BOL MKF Sociaal-pedagogisch werk

10

BOL MKF Sociaal-pedagogisch werker

BBL BB Kapper

$B B L$ ZB Verzorgende

BBL ZB All-round kapper

BBL MKF Detailhandel/ambulante handel

BOL AB Beveiliging

MBO Politie

BOL BB Beveiligingsmedewerker

BOL AB Toezichthouder

BOL BB Informatietechniek

BOL BB Beveiliging

BOL BB Bedrijfsadministratie

BOL MKF Systeembeheerder MKB

BOL MKF Directie-secretaresse/management-assistent

BOL MKF Administratie - vrije richting

BOL MKF Economie 
Tabel B2.2 (vervolg)

Belangrijkste opleidingen van schoolverlaters die een voltijd vervolgopleiding zijn gaan volgen

BOL BB Bedrijfsadministratie (vervolg)

BOL MKF Bedrijfsadministratief

BOL MKF Commercieel medewerker banken

BOL MKF Assistent-administrateur

HBO Commerciele economie

BOL BB Secretarieel

BOL MKF Directie-secretaresse/management-assistent 30

BBL ZB Secretaresse $\quad 25$

BOL MKF Secretarieel

BOL ZB Medewerker beheer informatiesystemen

BOL MKF Multimedia vormgever

BOL MKF Sociaal-juridisch werk

HBO Bedrijfskunde

BOL BB Detailhandel/ambulante handel

BOL MKF Detailhandel/ambulante handel

BOL MKF Ondernemer/manager detailhandel

BBL BB Verkoopmedewerker

BBL MKF Detailhandel/ambulante handel

BOL BB Beveiligingsmedewerker

BOL BB Helpende (verpleging en verzorging)

BOL Specialist ICT-beheerder

BBL MKF Sociaal-pedagogisch werk

BOL BB Horeca, instellingskeuken en contractcatering

BBL ZB Zelfstandig werkend kok

HBO Facilitair management

BOL BB Kok

MBO Politie

BOL BB Verpleging en verzorging

BOL MKF Verzorgende

BOL MKF Sociaal-pedagogisch werk

BBL ZB Verzorgende

BBL ZB Verzorgende bij inst. voor gezinsverz.

BOL ZB Verzorgende

BOL ZB Veehouderij

HBO Leraar basisonderwijs $\quad 20$

MBO Politie

BOL MKF Verpleegkundige

BOL ZB Bloemschikken

BBL Specialist Bloemschikken 16

BOL MKF Toerisme, recreatie en reizen 8

BBL KF Bloemschikken 8

BBL MKF Directiesecretaresse/management-assistent 8

HBO Kunst en cultuur $\quad 8$

BOL ZB Allround meubelmaker/interieurbouwer/scheepsinterieur 6

BOL MKF Onderwijsassistent 6

HBO Kort Marketing management $\quad 6$

HBO Kort Secretarieel medewerker 6

HBO Leraar basisonderwijs 6

HBO Toerisme en recreatie (bedrijfsmanagement) 6

BOL BB Beveiliging

BOL ZB Bedrijfsadministratief

BOL MKF Assistent-administrateur 32

HBO Management, economie en recht $\quad 15$ 
BOL ZB Bedrijfsadministratief (vervolg)

BOL MKF Administratie - vrije richting

HBO Accountancy

HBO Duaal Bedrijfseconomie

HBO Toerisme en recreatie (bedrijfsmanagement)

BOL ZB Secretarieel

BOL MKF Directie-secretaresse/management-assistent 29

BOL MKF Commercieel

BOL MKF Toerisme, recreatie en reizen

BOL ZB Secretaresse

BOL MKF Secretarieel

BOL ZB Detailhandel/ambulante handel

BOL MKF Assistent marketing en communicatie $\quad 14$

HBO Sociaal pedagogische hulpverlening 14

BOL MKF Ondernemer/manager detailhandel $\quad 11$

HBO Commerciele economie $\quad 7$

$\begin{array}{ll}\text { HBO Marketing } & 7\end{array}$

HBO Informatiedienstverlening en -management $\quad 7$

HBO Facilitaire dienstverlening

HBO Hoger toeristisch en recreatief onderwijs

HBO Personeelsmanagement

\section{BOL ZB Verpleging en verzorging}

BOL MKF Verpleegkundige

BBL MKF Verpleegkundige

BBL ZB Verzorgende bij inst. voor gezinsverz.

40

BOL ZB Uiterlijke verzorging

BOL ZB Schoonheidsspecialist

BOL MKF Toerisme, recreatie en reizen

BOL ZB Boekhoudkundig medewerker

BOL MKF Filiaalbeheerder

BBL ZB Secretaresse

BOL ZB Uiterlijke verzorging

BOL KF Plantenteelt

HBO Agrarische bedrijfskunde

HBO Plantenteelt

HBO Tuinbouw

HBO Bedrijfskunde

BOL KF Veehouderij

HBO Veehouderij

HBO Docent dier/veehouderij (2e gr.)

HBO Landbouw

HBO Agrarische bedrijfskunde

BOL KF Levensmiddelentechnologie

HBO Levensmiddelentechnologie

HBO Voeding en marketing

HBO Kort Milieu en chemie

HBO Agroproductkunde

HBO Docent levensmiddelentechnologie (2e gr.)

BOL MKF Sociaal-pedagogisch werker 
BOL KF Groene ruimte

HBO Tuin- en landschapsinrichting $\quad 24$

HBO Land-, water- en milieubeheer 17

HBO Landbouw $\quad 9$

\begin{tabular}{ll} 
HBO Bedrijfseconomie & 8 \\
\hline
\end{tabular}

$\begin{array}{ll}\text { HBO Tuinbouw } & 7\end{array}$

HBO Bos- en natuurbeheer

HBO Culturele en maatschappelijke vorming

HBO Plattelandsvernieuwing 6

BOL KF Milieutoezicht

HBO Milieukunde (technisch) $\quad 46$

HBO Milieukunde (agrarisch) $\quad 11$

HBO Kort Milieu management $\quad 9$

HBO Leraar basisonderwijs $\quad 9$

HBO Personeel en arbeid $\quad 9$

$\begin{array}{ll}\text { HBO Communicatie } & 7\end{array}$

BOL MKF Bouw

HBO Bouwkunde

HBO Civiele techniek

BOL MKF Houtbewerking en woninginrichting

HBO Industrieel product ontwerpen

HBO Kunst en cultuur

HBO Beeldende kunst en vormgeving - vrij

BOL MKF Grond-, water- en wegenbouw

HBO Civiele techniek

HBO Kort Weg- en waterbouwkundig opzichter/uitvoerder

HBO Land-, water- en milieubeheer

HBO Algemene operationele technologie

BOL MKF Reclame, presentatie en communicatie

HBO Visual Marketing in Fashion

HBO Kunst en cultuur

HBO Beeldende kunst en vormgeving - vrij

HBO Kort Marketing management

BOL MKF Grafisch vormgever

HBO Technisch-commerciele confectiekunde

HBO Marketing

HBO Communicatie

HBO Vrijetijdskunde

HBO Architectonische vormgeving

HBO Binnenhuis

HBO Fotografische vormgeving

BOL MKF Werktuigbouwkunde

HBO Werktuigbouwkunde

HBO Technische bedrijfskunde

BOL MKF Motorvoertuigen

HBO Autotechniek

HBO Werktuigbouwkunde

BBL ZB Eerste autotechnicus

BBL BB Autospuiter

BBL ZB Eerste autoschadehersteller

HBO Commerciele economie 
Belangrijkste opleidingen van schoolverlaters die een voltijd vervolgopleiding zijn gaan volgen

BOL MKF Energie- en informatietechniek

HBO Elektrotechniek

HBO Hogere informatica

HBO Technische informatica

BOL MKF Informatietechniek

HBO Informatica

HBO Hogere informatica

HBO Kort Informatica technologie

HBO Elektrotechniek

HBO Bedrijfskundige informatica

BOL MKF Graf. techn, communicatie, audiovisueel en multimedia

HBO Boekhandel en uitgeverij

HBO Communicatie

HBO Vrijetijdskunde

HBO Leraar tekenen (1e gr.)

HBO Kort Marketing management

HBO Commerciele economie

BOL MKF Laboratoriumtechniek

HBO Laboratoriumtechniek

HBO Biologie en medisch laboratoriumonderzoek

HBO Milieugerichte materiaaltechnologie

HBO Chemie

HBO Chemische technologie

BOL MKF Scheepvaart

HBO Maritiem officier

HBO Werktuigbouwkunde

BOL MKF Transport en logistiek

HBO Logistiek en technische vervoerskunde $\quad 40$

HBO Logistiek en economie $\quad 20$

HBO Communicatie

BOL MKF Logistiek

HBO Logistiek en vervoer

HBO Informatica en informatiekunde

HBO Management, economie en recht

BOL MKF Bedrijfsadministratief

HBO Bedrijfseconomie

HBO Accountancy

HBO Management, economie en recht

HBO Commerciele economie

HBO Financieel management

BOL MKF Commercieel

HBO Commerciele economie

HBO Management, economie en recht

HBO Economie

HBO Communicatie

HBO Logistiek en economie

HBO Leraar basisonderwijs

BOL MKF Economisch-juridisch

HBO Management, economie en recht

BOL MKF Sociaal-pedagogisch werker 
Belangrijkste opleidingen van schoolverlaters die een voltijd vervolgopleiding zijn gaan volgen

BOL MKF Economisch-juridisch (vervolg)

HBO Commerciele economie

HBO Sociaal-juridische dienstverlening

BOL MKF Secretarieel

HBO Personeel en arbeid

BOL MKF Detailhandel/ambulante handel

HBO Communicatie

HBO Commerciele economie

HBO Management, economie en recht

HBO Small business en retail management

BOL MKF Groothandel/distributie

HBO Commerciele economie

BOL MKF Horeca, instellingskeuken en contractcatering HBO Commerciele economie HBO Management, economie en recht HBO Facilitaire dienstverlening

HBO Hoger hotelonderwijs

HBO Kort Marketing management

HBO Kort Toerisme

HBO Financieel management

HBO Personeel en arbeid

BOL MKF Toerisme, recreatie en reizen

HBO Toerisme en recreatie (bedrijfsmanagement)

HBO Accountancy

HBO Kort Manager toeristische informatie

HBO Leraar basisonderwijs

HBO Bedrijfskaderopleiding (bouwkunde)

HBO Verkeerskunde

HBO Facilitaire dienstverlening

HBO Sociaal pedagogische hulpverlening

BOL MKF Assistent marketing en communicatie

BOL MKF Assistenten gezondheidszorg

HBO Opleiding tot verpleegkundige

HBO Opleiding mondhygienist

HBO Fysiotherapie

HBO Maatschappelijk werk en dienstverlening

BOL MKF Facilitaire dienstverlening

HBO Facilitaire dienstverlening

HBO Facilitair management

BOL MKF Sport en bewegen

HBO Leraar VO lichamelijke oefening (1e gr.)

HBO Toerisme en recreatie (bedrijfsmanagement) 
BOL MKF Maatschappelijke dienstverlening

HBO Maatschappelijk werk en dienstverlening

HBO Creatieve therapie

HBO Sociaal-juridische dienstverlening

HBO Sociaal pedagogische hulpverlening

HBO Personeel en arbeid

HBO Leraar VO maatschappijleer (2e gr.)

BOL MKF Sociaal-cultureel werker

HBO Leraar basisonderwijs

HBO Sociaal pedagogische hulpverlening

HBO Culturele en maatschappelijke vorming

HBO Toerisme en recreatie (bedrijfsmanagement)

HBO Maatschappelijk werk en dienstverlening

HBO Sociaal-juridische dienstverlening

BOL MKF Sociaal-pedagogisch werk algemeen

HBO Sociaal pedagogische hulpverlening

HBO Leraar basisonderwijs

HBO Maatschappelijk werk en dienstverlening

HBO Pedagogiek

BOL MKF Sociaal-juridisch werk

HBO Personeel en arbeid

HBO Sociaal-juridische dienstverlening

HBO Maatschappelijk werk en dienstverlening

HBO Leraar VO Frans (2e gr.)

HBO Trade management gericht op Azie

$\mathrm{HBO}$ Small business en retail management

HBO Informatiedienstverlening en -management

BBL BB Bouw

BBL ZB Voortgezette timmerkracht

BBL BB Constructie-, plaatwerken/pijpenbewerken

BBL ZB Constructie- en apparatenbouwer

BBL BB Machinebankwerken/verspanen

BOL MKF Werktuigbouwkunde

BBL ZB Machinaal verspaner

BOL ZB Werktuigbouwkunde

BBL ZB Programmeur/verspaner CNC

BBL BB Installatie-, service- en onderhoudstechniek

BBL ZB Installatie-, service- en onderhoudstechnie

$\mathrm{BBL}$ ZB Installatiemonteur met specialisatie woningbouw

BBL ZB Verwarmingsmonteur

BBL BB Stukadoor

BBL BB Assistent-installatiemonteur (verwarmingstechniek)

$\mathrm{BBL}$ ZB Installatiemonteur met specialisatie dakbedekkingen

BBL ZB Servicemonteur installatietechniek

BBL BB Wegvervoer

BBL BB Chauffeur goederenvervoer

BBL ZB Warehouse voorman

BBL MKF Transport en logistiek 
Belangrijkste opleidingen van schoolverlaters die een voltijd vervolgopleiding zijn gaan volgen

BBL BB Detailhandel/ambulante handel

BBL ZB Eerste verkoper

BBL BB Verkoopmedewerker

BBL ZB Verkoopchef

BBL AB Detailhandel/ambulante handel

BBL MKF Detailhandel/ambulante handel

BOL ZB Secretarieel

$B B L Z B$ Zelfstandig werkend medewerker recreatie

BBL ZB Leidster kindercentra

BBL BB Horeca, instellingskeuken en contractcatering

BBL ZB Zelfstandig werkend kok

BBL ZB Zelfstandig werkend gastheer/-vrouw

HAVO

BOL MKF Techniek

BBL BB Kok

BBL ZB Bouw

BBL MKF Assistent-uitvoerder B\&U

BBL BB Werkplaatstimmerman

BOL AB Assistent-monteur nieuwbouwinstallaties

HBO Leraar VO bouwkunde I en II (2e gr.)

BBL ZB Grond-, water- en wegenbouw

BOL MKF Grond-, water- en wegenbouw

BBL ZB Grond-, water- en wegenbouw

BBL MKF Uitvoerder

BBL ZB Machinist grondverzetmachines

BBL ZB Onderhoudsmonteur verwarmingstechniek

BBL ZB Straatmaker

BBL ZB Installatie-, service- en onderhoudstechniek

BBL Specialist Servicetechnicus

BBL ZB Servicemonteur verwarmingstechniek

BBL BB Onderhoudsmonteur elektro en instrumentatie

BOL ZB Servicemonteur koudetechniek

$B O L$ MKF Meet- en regeltechniek

BBL AB Installatie-, service- en onderhoudstechniek

BBL ZB Beheer, ontwerp en management (installatietechniek)

BBL ZB Aankomend projecttechnicus gebouwinstallaties

BBL ZB Servicemonteur installatietechniek

BBL KF Landbouw

BBL MKF Economie

BBL ZB Detailhandel/ambulante handel

BBL ZB Verkoopchef

BBL MKF Ondernemer/manager detailhandel

BBL ZB Detailhandel/ambulante handel

BBL ZB Eerste verkoper

BBL MKF Filiaalbeheerder

BBL MKF Ondernemer ambulante handel

$B B L Z B$ Verpleging en verzorging

BBL MKF Verpleegkundige

BBL Specialist Praktijkopleider (verpleging en verzorgende)

BOL MKF Sociaal-juridisch medewerker - sociale zekerheid

$B B L Z B$ Verpleging en verzorging

BBL MKF Verpleging en verzorging 
Tabel B2.3

Oordeel van schoolverlaters over de aansluiting van de afgesloten opleiding met de voltijd vervolgopleiding

\begin{tabular}{rrrrr}
\hline Opleidingsrichting & goed & $\begin{array}{r}\text { vol- } \\
\text { doende } \\
\%\end{array}$ & $\%$ & $\%$
\end{tabular}

VBO

IVBO Verzorging

Bouwtechniek

Mechanische techniek

Elektrotechniek

Motorvoertuigentechniek

Consumptieve techniek

Administratie

Verkoop

Handel

Verzorging

Uiterlijke verzorging

$\begin{array}{rrrr}57 & 21 & 19 & 4 \\ 32 & 35 & 23 & 11 \\ 29 & 25 & 35 & 11 \\ 35 & 35 & 20 & 10 \\ 31 & 38 & 31 & 0 \\ 28 & 47 & 14 & 11 \\ 27 & 54 & 14 & 4 \\ 34 & 39 & 16 & 12 \\ 23 & 39 & 23 & 14 \\ 43 & 40 & 12 & 5 \\ 20 & 36 & 25 & 19\end{array}$

BOL niveau $1 / 2$

$A B$ Beveiliging

BB Bedrijfsadministratie

BB Secretarieel

BB Detailhandel/ambulante handel

BB Horeca, instellingskeuken en contractcatering

BB Verpleging en verzorging

\begin{tabular}{|c|c|c|}
\hline 45 & 39 & 7 \\
\hline 42 & 35 & 19 \\
\hline 42 & 38 & 15 \\
\hline 41 & 21 & 31 \\
\hline 21 & 43 & 26 \\
\hline 34 & 34 & 27 \\
\hline
\end{tabular}

BOL niveau $3 / 4$

ZB Veehouderij

ZB Bloemschikken

ZB Bedrijfsadministratief

ZB Secretarieel

ZB Detailhandel/ambulante handel

ZB Verpleging en verzorging

ZB Uiterlijke verzorging

KF Plantenteelt

KF Veehouderij

KF Levensmiddelentechnologie

KF Bloemschikken

KF Groene ruimte

KF Milieutoezicht

MKF Bouw

MKF Houtbewerking en woninginrichting

MKF Grond-, water- en wegenbouw

MKF Reclame, presentatie en communicatie

MKF Werktuigbouwkunde

MKF Motorvoertuigen

MKF Energie- en informatietechniek

MKF Informatietechniek

MKF Graf. techn, communicatie, audiovisueel en multimedia

MKF Laboratoriumtechniek

MKF Scheepvaart

MKF Transport en logistiek

MKF Bedrijfsadministratief

MKF Commercieel

MKF Economisch-juridisch

MKF Secretarieel

MKF Detailhandel/ambulante handel

MKF Groothandel/distributie

MKF Horeca, instellingskeuken en contractcatering

MKF Toerisme, recreatie en reizen

MKF Assistenten gezondheidszorg

MKF Facilitaire dienstverlening

$\begin{array}{rrrr}6 & 17 & 52 & 26 \\ 28 & 44 & 24 & 5 \\ 42 & 10 & 48 & 0 \\ 46 & 32 & 11 & 10 \\ 57 & 14 & 22 & 7 \\ 36 & 36 & 15 & 12 \\ 56 & 16 & 11 & 18 \\ 47 & 13 & 40 & 0 \\ 29 & 42 & 23 & 6 \\ 34 & 28 & 22 & 16 \\ 29 & 25 & 38 & 9 \\ 29 & 45 & 14 & 12 \\ 58 & 37 & 0 & 5 \\ 46 & 37 & 14 & 4 \\ 22 & 41 & 20 & 17 \\ 48 & 36 & 6 & 11 \\ 53 & 26 & 16 & 5 \\ 35 & 40 & 19 & 6 \\ 26 & 36 & 19 & 19 \\ 30 & 38 & 23 & 9 \\ 34 & 38 & 26 & 2 \\ 44 & 32 & 13 & 11 \\ 38 & 51 & 8 & 4 \\ 17 & 33 & 42 & 8 \\ 36 & 44 & 16 & 5 \\ 33 & 44 & 16 & 7 \\ 30 & 42 & 14 & 14 \\ 44 & 24 & 16 & 16 \\ 42 & 31 & 23 & 4 \\ 24 & 37 & 29 & 11 \\ 45 & 28 & 18 & 9 \\ 36 & 44 & 17 & 3 \\ 35 & 41 & 12 & 12 \\ 27 & 44 & 19 & 10 \\ 21 & 42 & 26 & 11\end{array}$


Tabel B2.3 (vervolg)

Oordeel van schoolverlaters over de aansluiting van de afgesloten opleiding met de voltijd vervolgopleiding

\begin{tabular}{lrrrr}
\hline Opleidingsrichting & goed & $\begin{array}{r}\text { vol- } \\
\text { doende }\end{array}$ & matig & slecht \\
& $\%$ & $\%$ & $\%$ & $\%$ \\
\hline
\end{tabular}

BOL niveau $3 / 4$ (vervolg)

MKF Sport en bewegen

MKF Maatschappelijke dienstverlening

$\begin{array}{lll}41 & 29 & 23\end{array}$

MKF Sociaal-cultureel werker

$\begin{array}{llll}31 & 33 & 29 & 7\end{array}$

MKF Sociaal-pedagogisch werk algemeen

$19 \quad 28$

MKF Sociaal-juridisch werk

31

30

40
40

46

22

Zie ook toelichting bladzijde 16 
Tabel B2.4

Doorstroom van schoolverlaters naar de beroepsbegeleidende leerweg

IVBO Landbouw en natuurlijke omgeving

OVDB

LOBAS

VTL

IVBO Verzorging

OVDB

SOB\&B

VBO Landbouw en natuurlijke omgeving

OVDB

LOBAS

ECABO

SVH

Ken. en opl. centr. Handel

VBO Bouwtechniek

SH\&M

Bouwradius

VBO Mechanische techniek

SOM

LOBAS

VEV/LOB-E

VBO Elektrotechniek

VEV/LOB-E

SOM

ECABO

VBO Motorvoertuigentechniek

VTL

INNOVAM

VBO Consumptieve techniek

$\mathrm{SVH}$

VBO Administratie

ECABO

OVDB

Ken. en opl. centr. Handel

VBO Verkoop

Ken. en opl. centr. Handel 26

OVDB

ECABO

VBO Handel

SVH

OVDB

ECABO

Ken. en opl. centr. Handel

VBO Verzorging

OVDB

VBO Uiterlijke verzorging

KOC

OVDB

Ken. en opl. centr. Handel 
BOL AB Beveiliging

ECABO

BOL BB Bedrijfsadministratie

ECABO

BOL BB Secretarieel

ECABO

OVDB

GOC

BOL BB Detailhandel/ambulante handel

Ken. en opl. centr. Handel

OVDB

ECABO

BOL BB Horeca, instellingskeuken en contractcatering

SVH

OVDB

BOL BB Verpleging en verzorging

OVDB

SVH

BOL ZB Veehouderij

ECABO

OVDB

LOBAS

BOL ZB Bloemschikken

LOBAS

ECABO

SVH

SH\&M

OVDB

BOL ZB Bedrijfsadministratief

ECABO

BOL ZB Secretarieel

ECABO

BOL ZB Detailhandel/ambulante handel ECABO

$B O L Z B$ Verpleging en verzorging

BOL ZB Uiterlijke verzorging

KOC

ECABO

SVH

Ken. en opl. centr. Handel

BOL KF Plantenteelt

LOBAS

Ken. en opl. centr. Handel 
BOL KF Veehouderij

SOM

VTL

LOBAS

SBW

$\mathrm{SH} \& \mathrm{M}$

BOL KF Levensmiddelentechnologie

BOL KF Bloemschikken

$S H \& M$

OVDB

LOBAS

ECABO

BOL KF Groene ruimte

LOBAS

ECABO

BOL MKF Bouw

Bouwradius

SH\&M

BOL MKF Houtbewerking en woninginrichting

SH\&M

OVDB

BOL MKF Grond-, water- en wegenbouw SBW

BOL MKF Reclame, presentatie en communicatie GOC

BOL MKF Werktuigbouwkunde

SOM

VaPro

VTL

BOL MKF Motorvoertuigen

VOC-Car

INNOVAM

BOL MKF Energie- en informatietechniek

VEV/LOB-E

Intechnium

BOL MKF Graf. techn, communicatie, audiovisueel en multimedia ECABO

BOL MKF Laboratoriumtechniek

VaPro

In-service Laborant

BOL MKF Scheepvaart 
BOL MKF Transport en logistiek

BOL MKF Bedrijfsadministratief

GOC

ECABO

BOL MKF Commercieel

ECABO

MBO rest

BOL MKF Economisch-juridisch

OVDB

ECABO

BOL MKF Secretarieel

OVDB

ECABO

BOL MKF Detailhandel/ambulante handel

ECABO

KOC

Ken. en opl. centr. Handel

VEV/LOB-E

Intechnium

BOL MKF Groothandel/distributie

ECABO

BOL MKF Horeca, instellingskeuken en contractcatering

SVH

ECABO

OVDB

BOL MKF Toerisme, recreatie en reizen ECABO

BOL MKF Assistenten gezondheidszorg

OVDB

SVGB

ECABO

In-service Operatie-assistent

In-service Laborant

BOL MKF Facilitaire dienstverlening

SVH

MBO rest

BOL MKF Sport en bewegen OVDB

BOL MKF Sociaal-cultureel werker OVDB

BOL MKF Sociaal-pedagogisch werk algemeen

OVDB

ECABO

SVH 
BOL MKF Sociaal-juridisch werk

OVDB

BBL BB Bouw

Bouwradius

BBL BB Constructie-, plaatwerken/pijpenbewerken SOM

BBL BB Machinebankwerken/verspanen

SOM

BBL BB Installatie-, service- en onderhoudstechniek

Intechnium

BBL BB Wegvervoer

VTL

INNOVAM

ECABO

BBL BB Detailhandel/ambulante handel

Ken. en opl. centr. Handel

ECABO

SVH

OVDB

BBL BB Horeca, instellingskeuken en contractcatering SVH

BBL ZB Bouw

Bouwradius

$\mathrm{SH} \& \mathrm{M}$

VEV/LOB-E

BBL ZB Grond-, water- en wegenbouw

SBW

SVS

Intechnium

BBL ZB Installatie-, service- en onderhoudstechniek Intechnium

BBL ZB Detailhandel/ambulante handel

Ken. en opl. centr. Handel

$B B L Z B$ Verpleging en verzorging

Zie ook toelichting bladzijde 19 


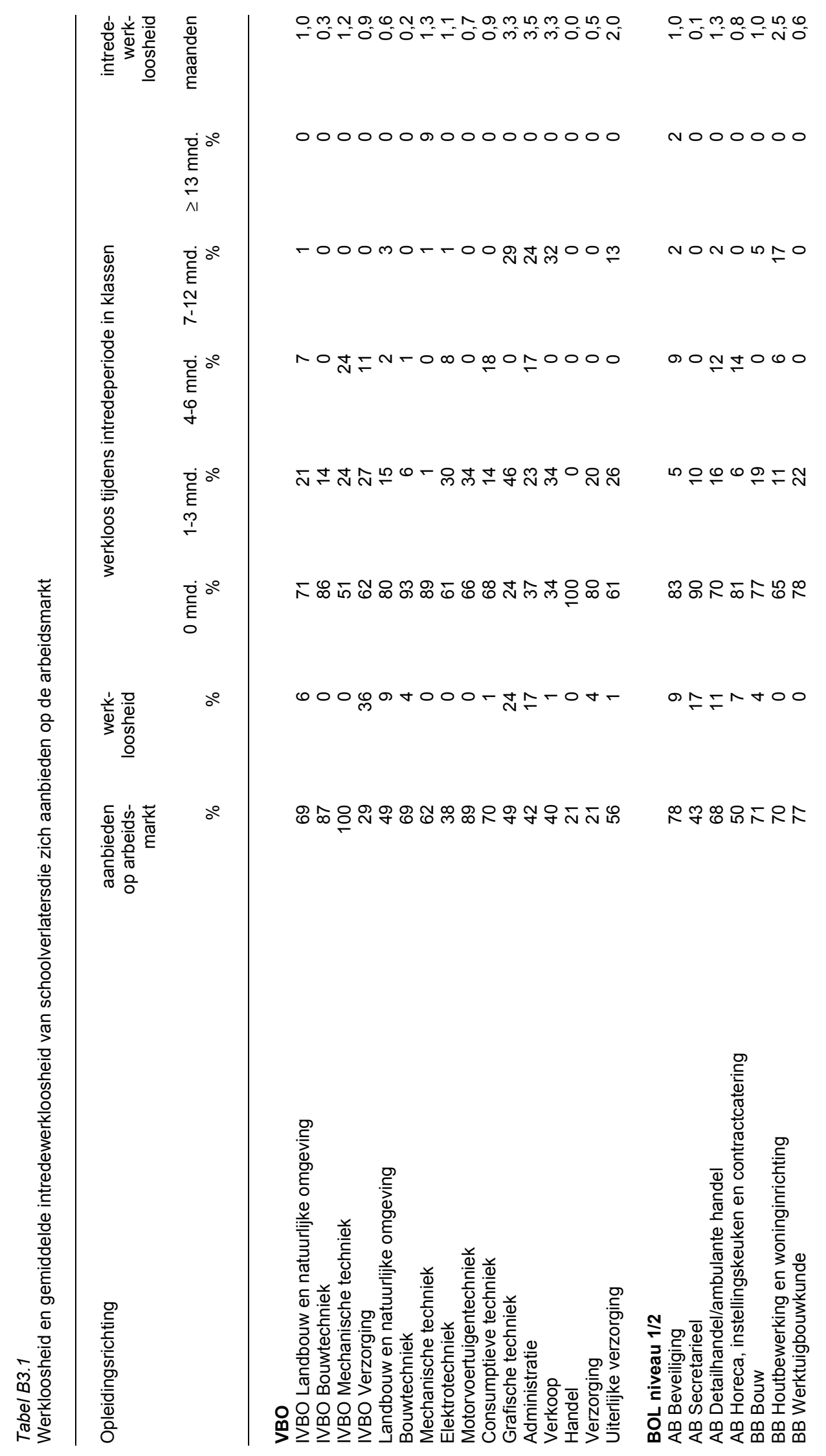




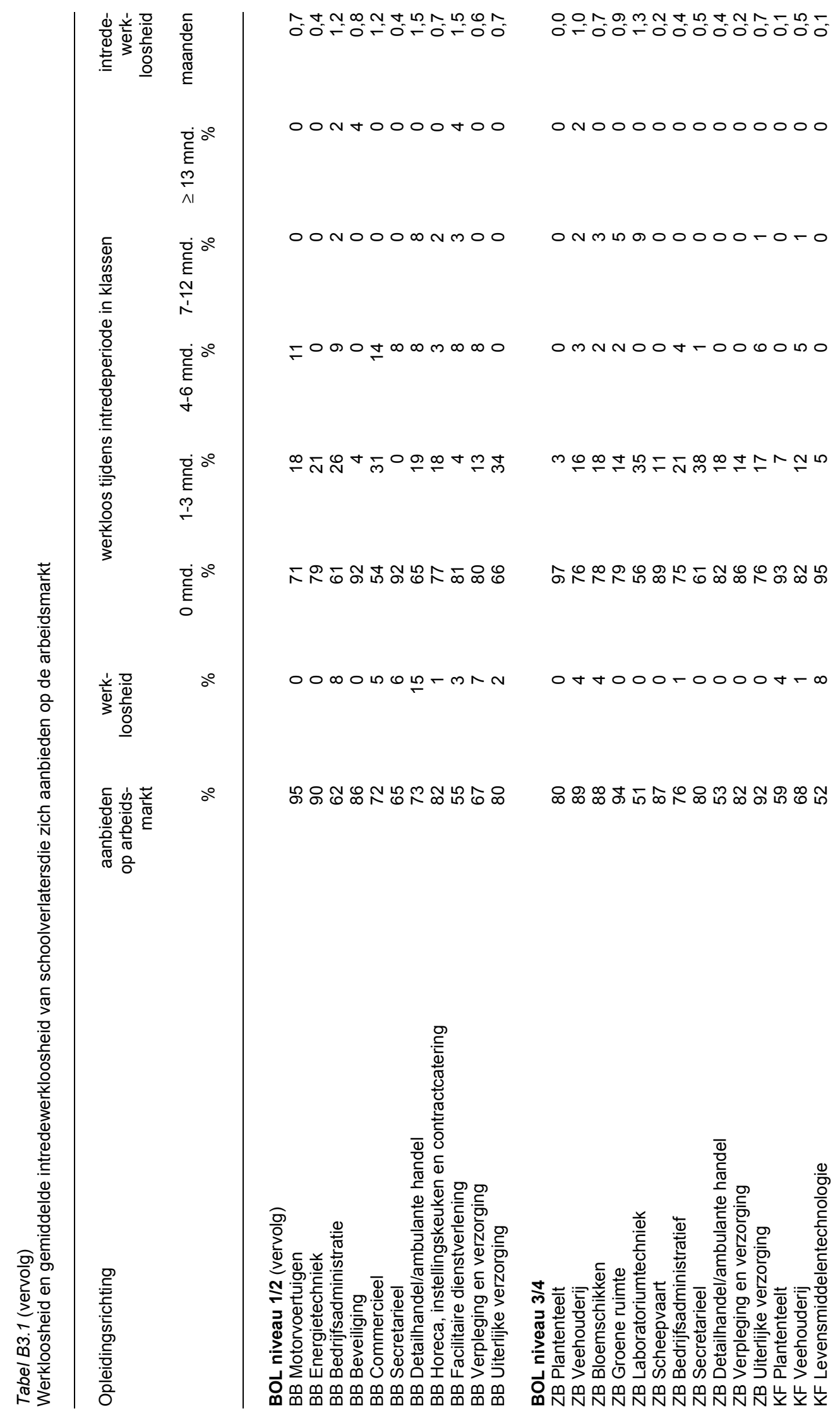




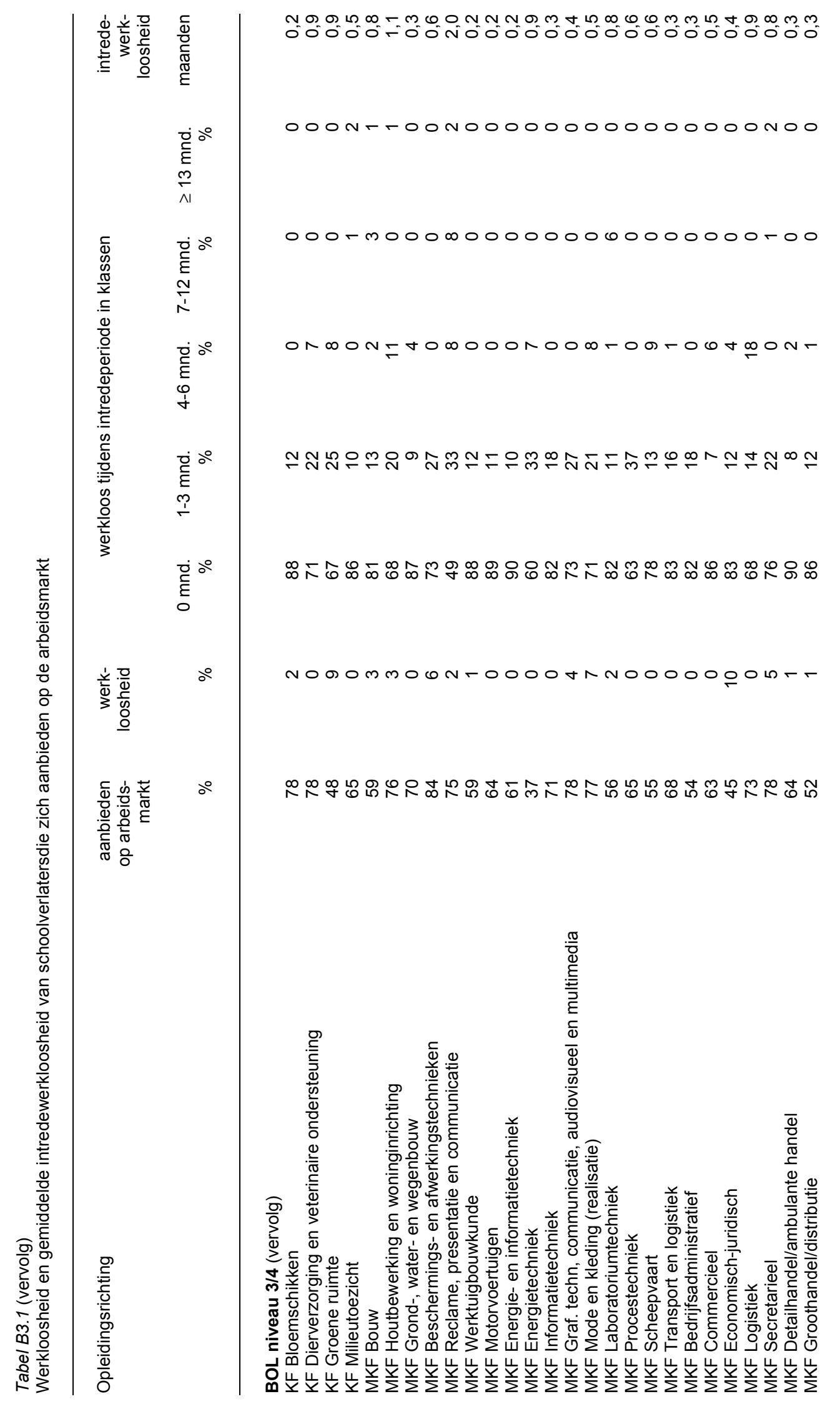




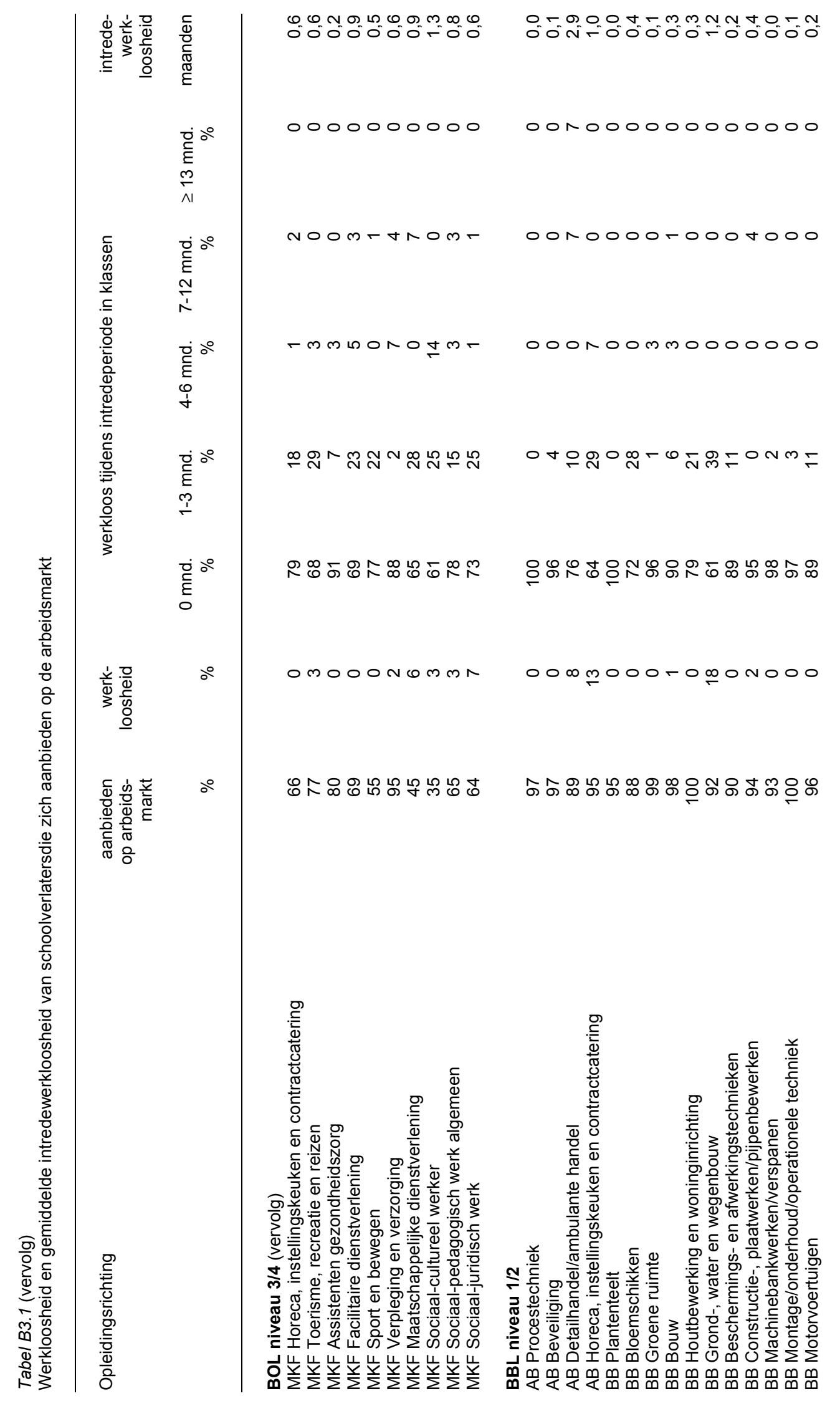




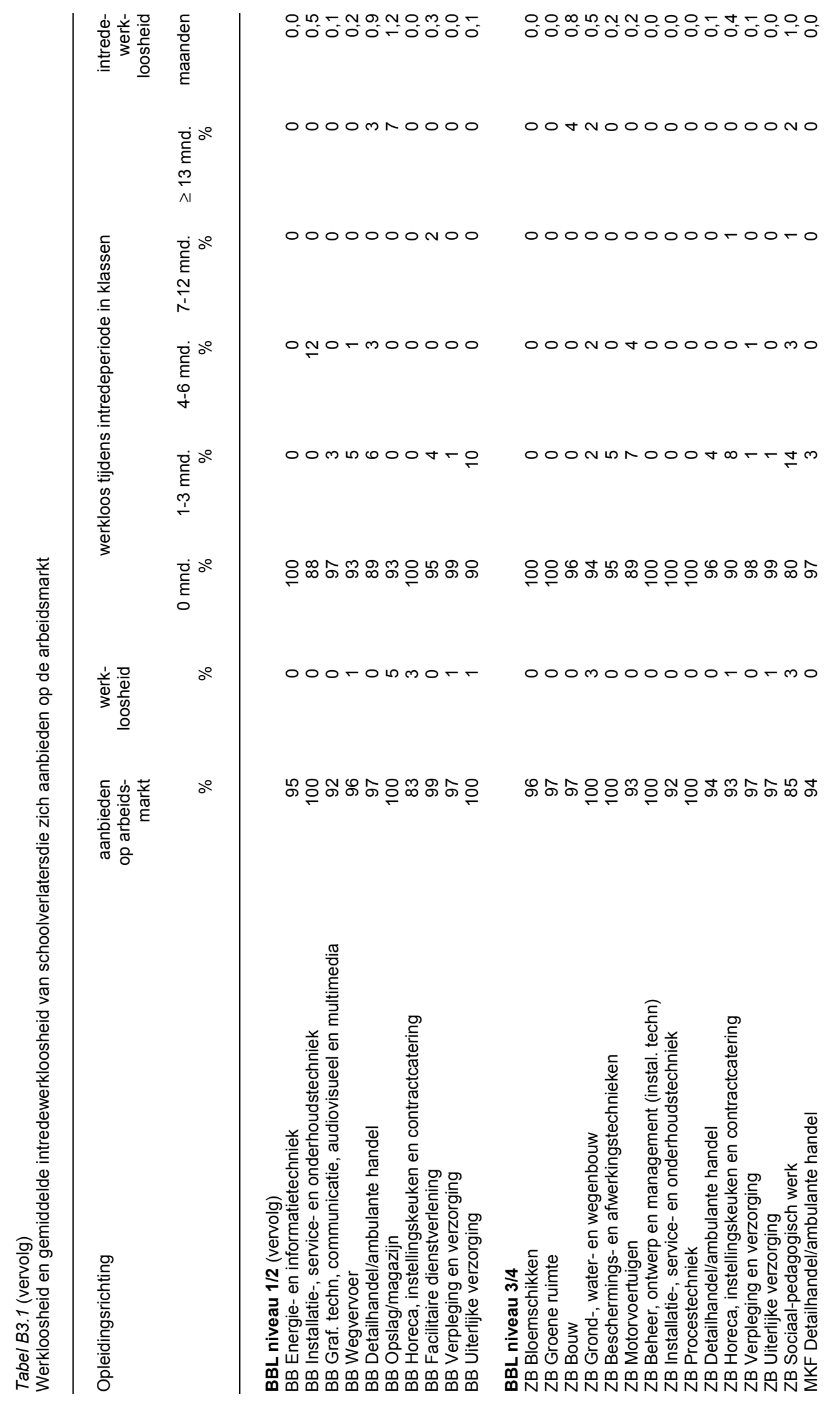




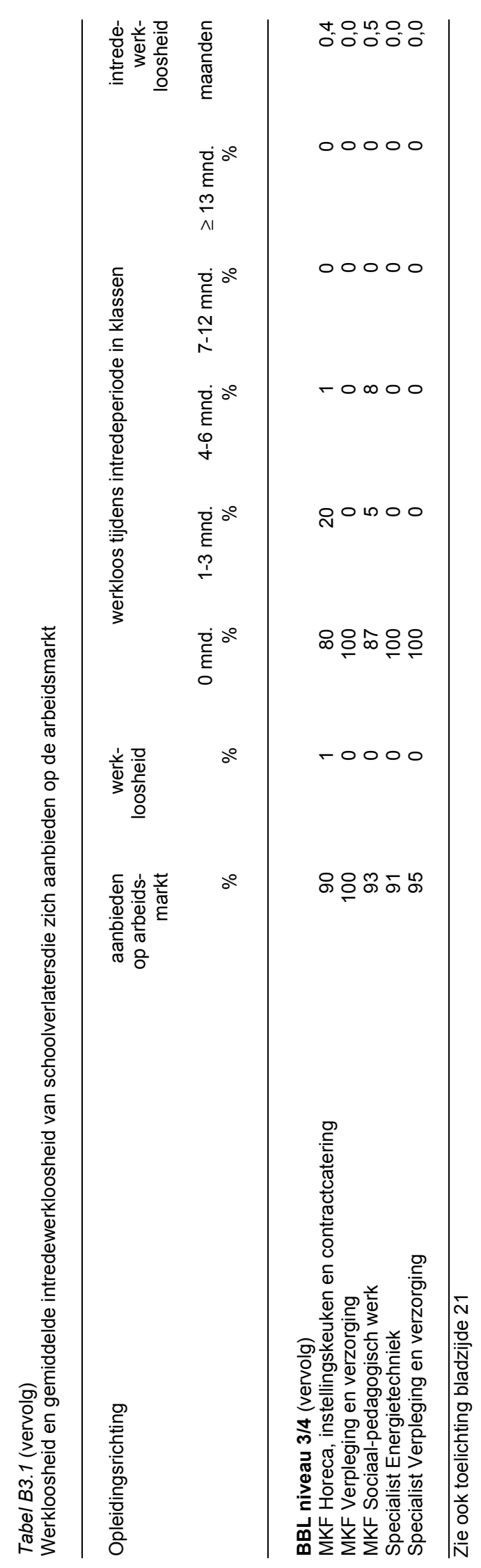




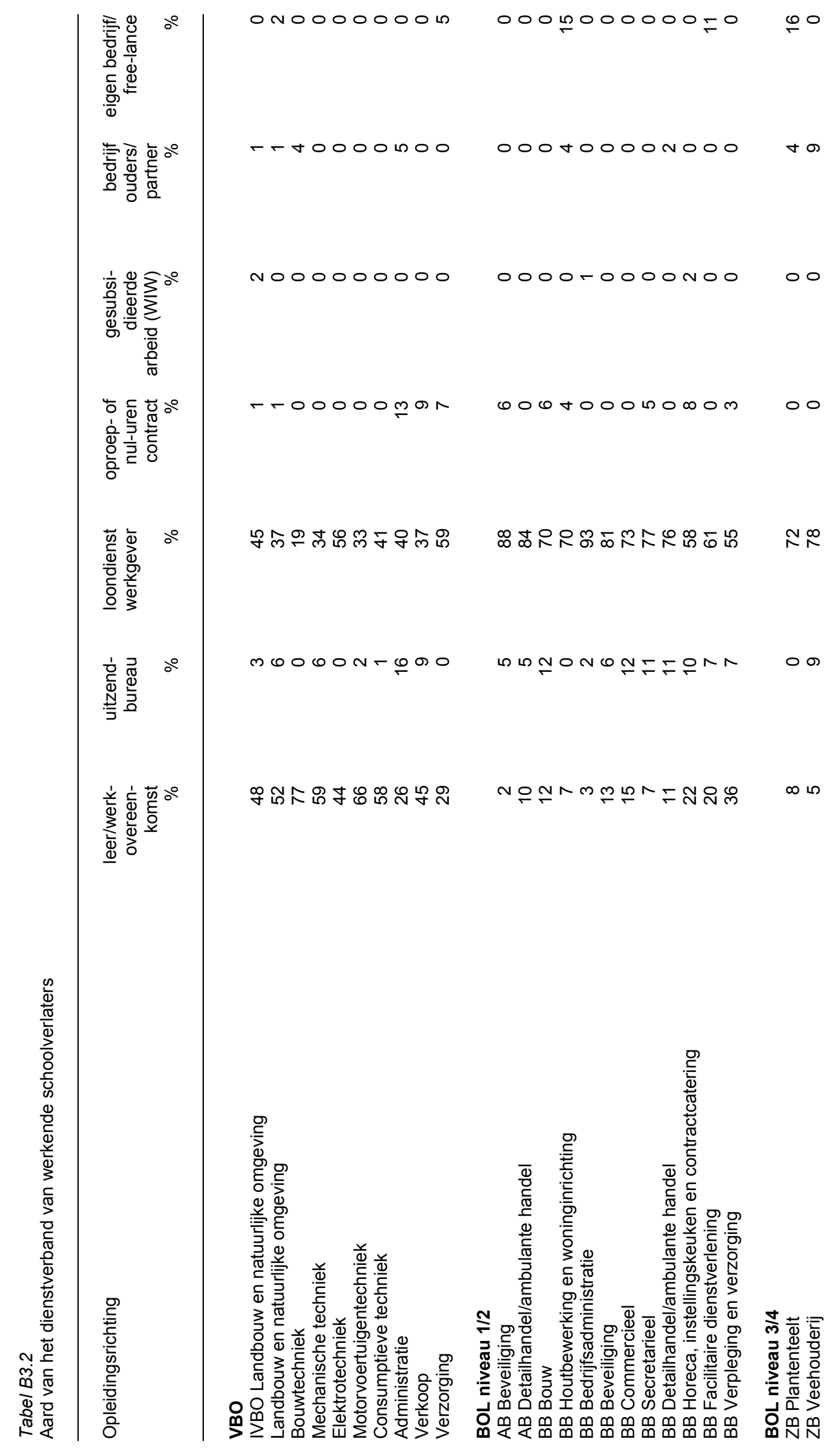




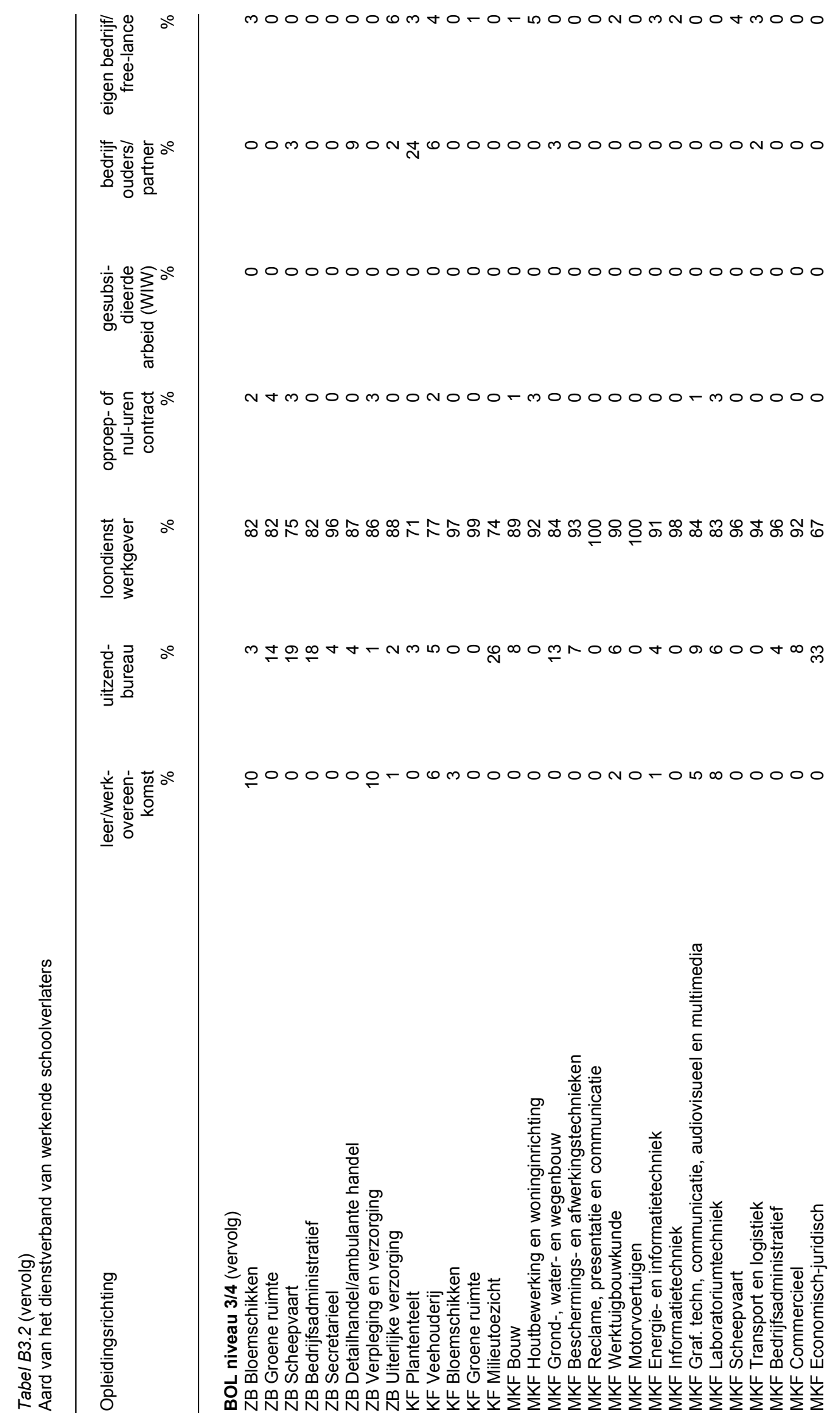




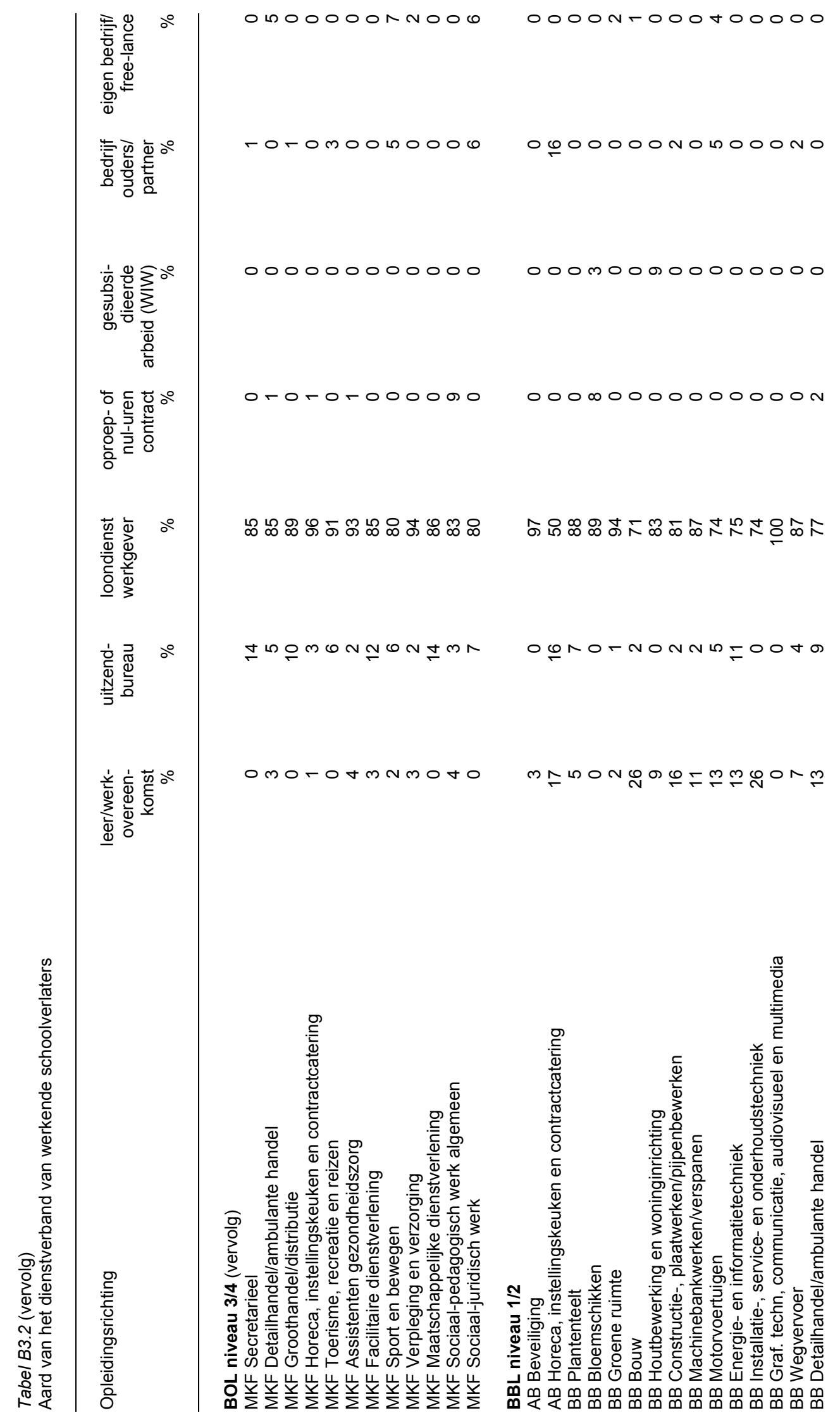




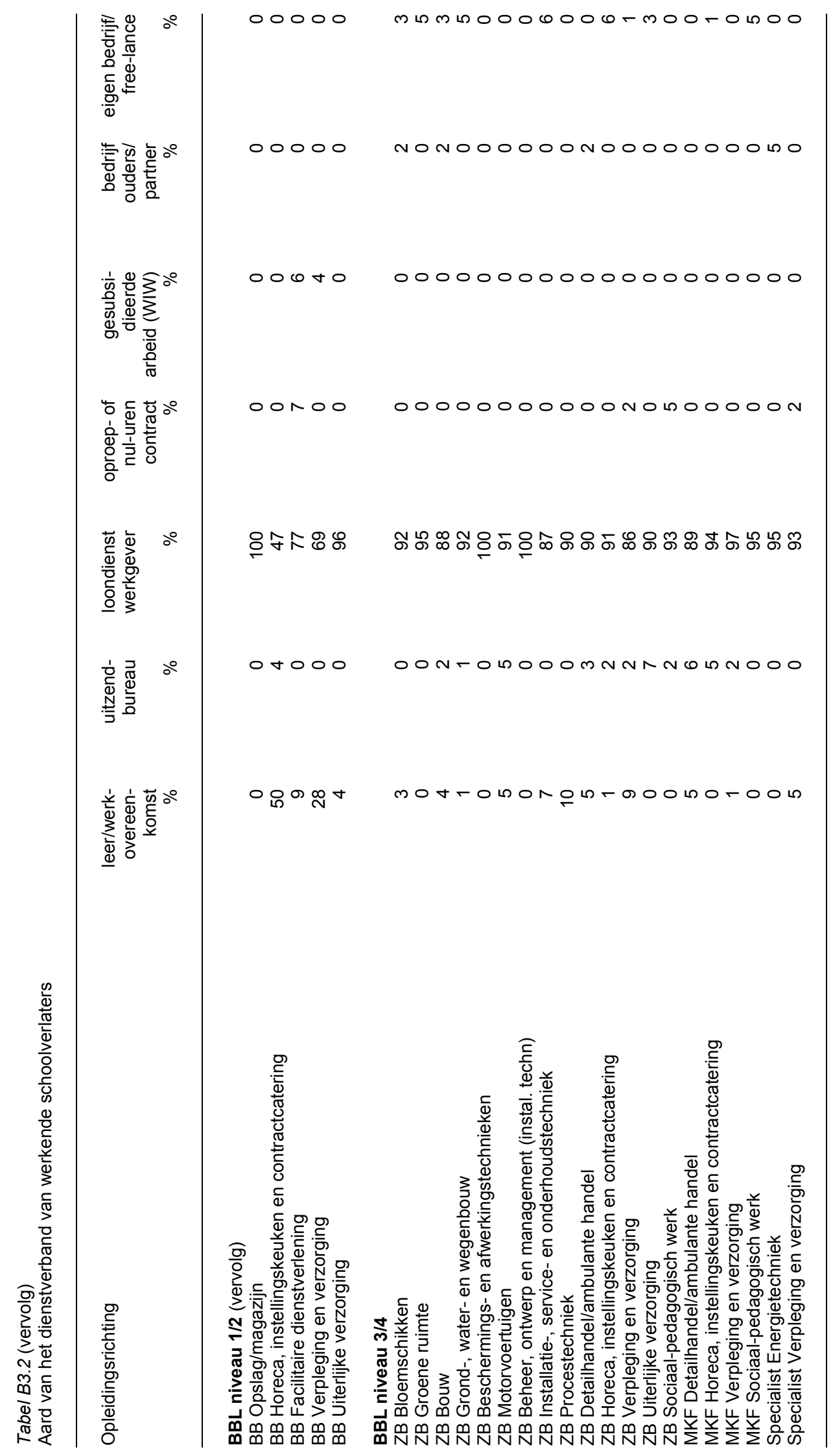


Tabel B3.3

Percentage werkende schoolverlaters met een flexibele aanstelling

Opleidingsrichting

VBO

IVBO Landbouw en natuurlijke omgeving $\quad 15$

Landbouw en natuurlijke omgeving $\quad 14$

$\begin{array}{lr}\text { Mechanische techniek } & 29\end{array}$

Elektrotechniek

$\begin{array}{ll}\text { Motorvoertuigentechniek } & 7\end{array}$

$\begin{array}{lr}\text { Consumptieve techniek } & 1\end{array}$

$\begin{array}{ll}\text { Administratie } & 47\end{array}$

Verkoop 36

Verzorging

BOL niveau $1 / 2$

AB Beveiliging

AB Detailhandel/ambulante handel $\quad 13$

BB Bouw $\quad 14$

BB Houtbewerking en woninginrichting

BB Bedrijfsadministratie $\quad 18$

BB Beveiliging 17

BB Commercieel $\quad 15$

BB Secretarieel $\quad 39$

BB Detailhandel/ambulante handel $\quad 25$

BB Horeca, instellingskeuken en contractcatering $\quad 25$

BB Facilitaire dienstverlening $\quad 13$

BB Verpleging en verzorging $\quad 13$

BOL niveau 3/4

ZB Plantenteelt

ZB Veehouderij

5

20

ZB Bloemschikken $\quad 5$

ZB Groene ruimte $\quad 26$

ZB Scheepvaart $\quad 22$

$\begin{array}{lr}\text { ZB Bedrijfsadministratief } & 18\end{array}$

ZB Secretarieel $r$

ZB Detailhandel/ambulante handel $\quad 18$

ZB Verpleging en verzorging $\quad 5$

ZB Uiterlijke verzorging $\quad 18$

KF Plantenteelt $\quad 3$

$\begin{array}{lr}\text { KF Veehouderij } & 10\end{array}$

KF Bloemschikken $\quad 13$

KF Groene ruimte $\quad 24$

KF Milieutoezicht $\quad 32$

MKF Bouw $\quad 16$

MKF Houtbewerking en woninginrichting 10

MKF Grond-, water- en wegenbouw 13

MKF Beschermings- en afwerkingstechnieken $\quad 7$

MKF Reclame, presentatie en communicatie $\quad 16$

MKF Werktuigbouwkunde $\quad 10$

$\begin{array}{ll}\text { MKF Motorvoertuigen } & 7\end{array}$

MKF Energie- en informatietechniek $\quad 7$

MKF Informatietechniek $\quad 4$

MKF Graf. techn, communicatie, audiovisueel en multimedia 13

$\begin{array}{lr}\text { MKF Laboratoriumtechniek } & 18\end{array}$

MKF Scheepvaart $\quad 4$

MKF Transport en logistiek $\quad 8$

MKF Bedrijfsadministratief $r$

MKF Commercieel 11

$\begin{array}{ll}\text { MKF Economisch-juridisch } & 42\end{array}$

21

MKF Detailhandel/ambulante handel $\quad 15$ 
Tabel B3.3 (vervolg)

Percentage werkende schoolverlaters met een flexibele aanstelling

Opleidingsrichting

BOL niveau 3/4 (vervolg)

MKF Groothandel/distributie

MKF Horeca, instellingskeuken en contractcatering

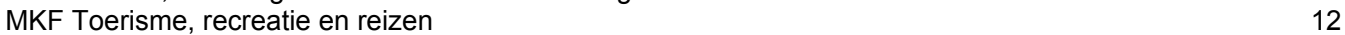

MKF Assistenten gezondheidszorg $\quad 4$

MKF Facilitaire dienstverlening $\quad 21$

$\begin{array}{lr}\text { MKF Sport en bewegen } & 14\end{array}$

MKF Verpleging en verzorging $\quad 3$

$\begin{array}{ll}\text { MKF Maatschappelijke dienstverlening } & 20\end{array}$

MKF Sociaal-pedagogisch werk algemeen $\quad 16$

MKF Sociaal-juridisch werk 14

BBL niveau $1 / 2$

$A B$ Beveiliging 3

AB Horeca, instellingskeuken en contractcatering $\quad 50$

BB Plantenteelt $\quad 12$

BB Bloemschikken $\quad 12$

BB Groene ruimte $\quad 6$

BB Bouw $\quad 6$

$\begin{array}{ll}\text { BB Constructie-, plaatwerken/pijpenbewerken } & 7\end{array}$

BB Machinebankwerken/verspanen $\quad 6$

BB Motorvoertuigen $\quad 16$

BB Energie- en informatietechniek 11

BB Installatie-, service- en onderhoudstechniek 1

BB Graf. techn, communicatie, audiovisueel en multimedia $\quad 2$

BB Wegvervoer $\quad-13$

BB Detailhandel/ambulante handel $\quad 16$

BB Opslag/magazijn $\quad 5$

BB Horeca, instellingskeuken en contractcatering $\quad 9$

BB Facilitaire dienstverlening $\quad 9$

BB Uiterlijke verzorging $\quad 15$

BBL niveau $3 / 4$

ZB Bloemschikken

ZB Bouw

ZB Grond-, water- en wegenbouw

ZB Beschermings- en afwerkingstechnieken

ZB Motorvoertuigen

ZB Beheer, ontwerp en management (instal. techn)

ZB Installatie-, service- en onderhoudstechniek

ZB Procestechniek

ZB Detailhandel/ambulante handel

ZB Horeca, instellingskeuken en contractcatering

ZB Verpleging en verzorging

ZB Uiterlijke verzorging

ZB Sociaal-pedagogisch werk

MKF Detailhandel/ambulante handel

MKF Horeca, instellingskeuken en contractcatering

MKF Verpleging en verzorging

Specialist Verpleging en verzorging

Zie toelichting bladzijde 25 


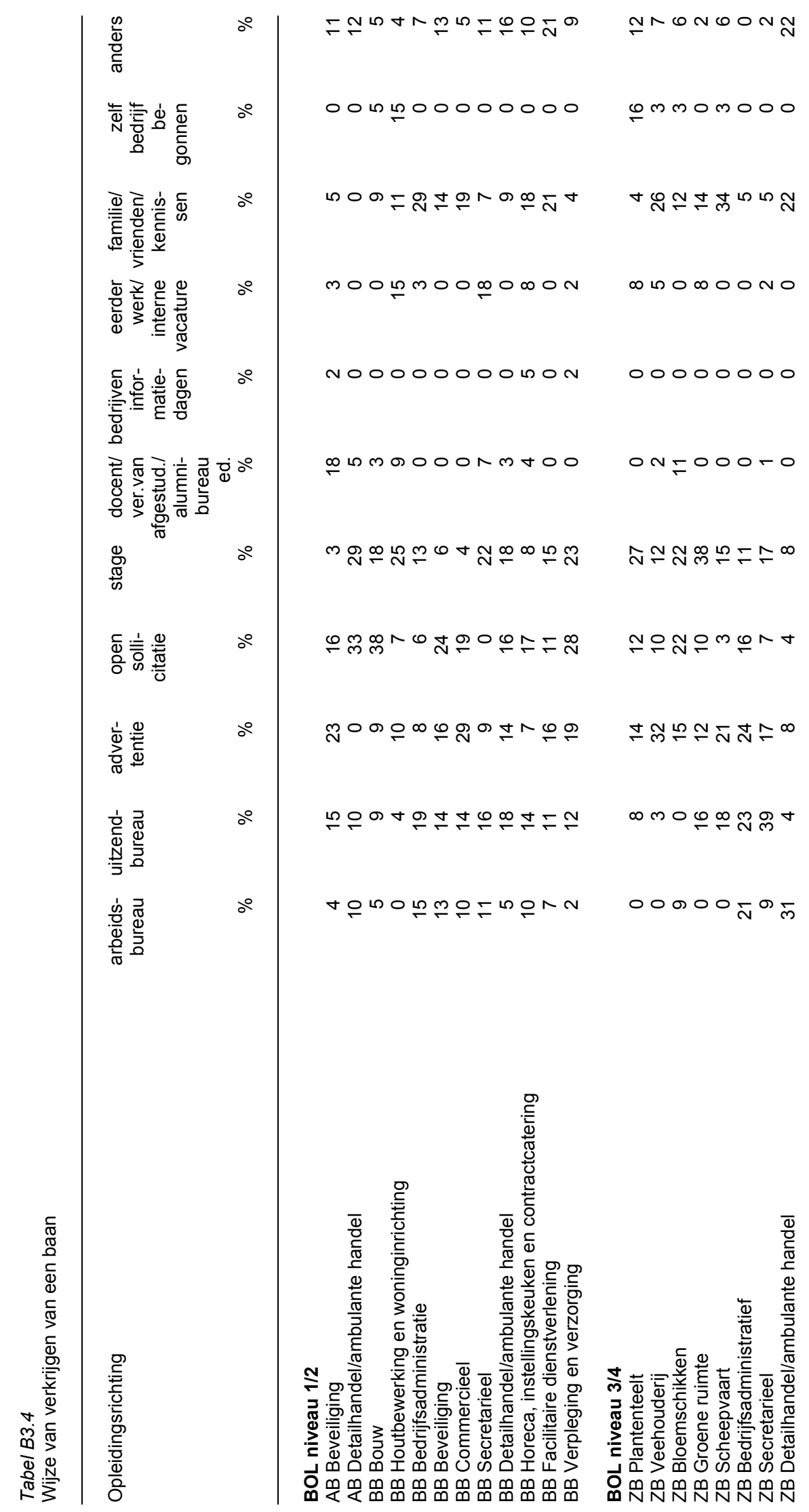




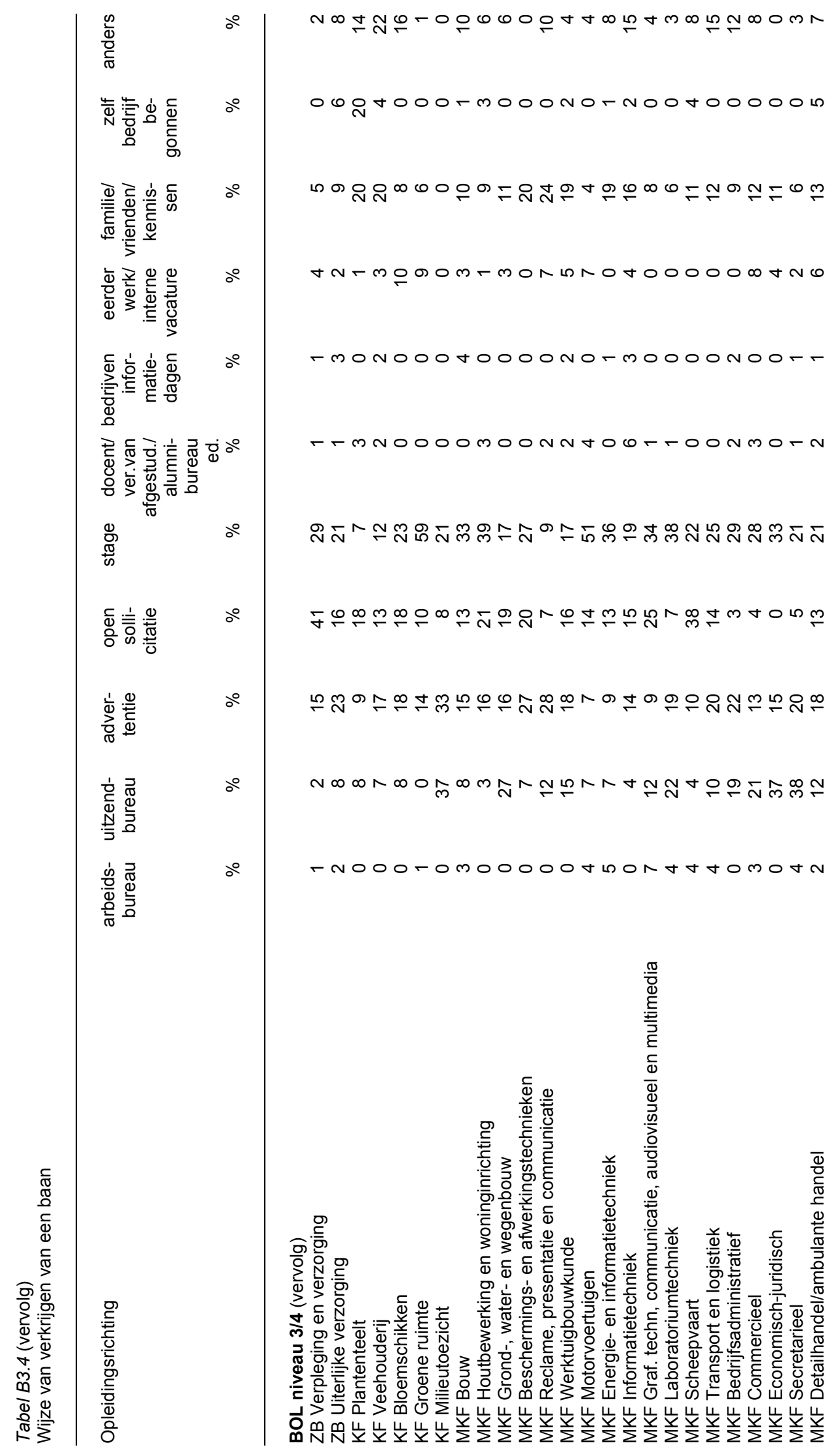




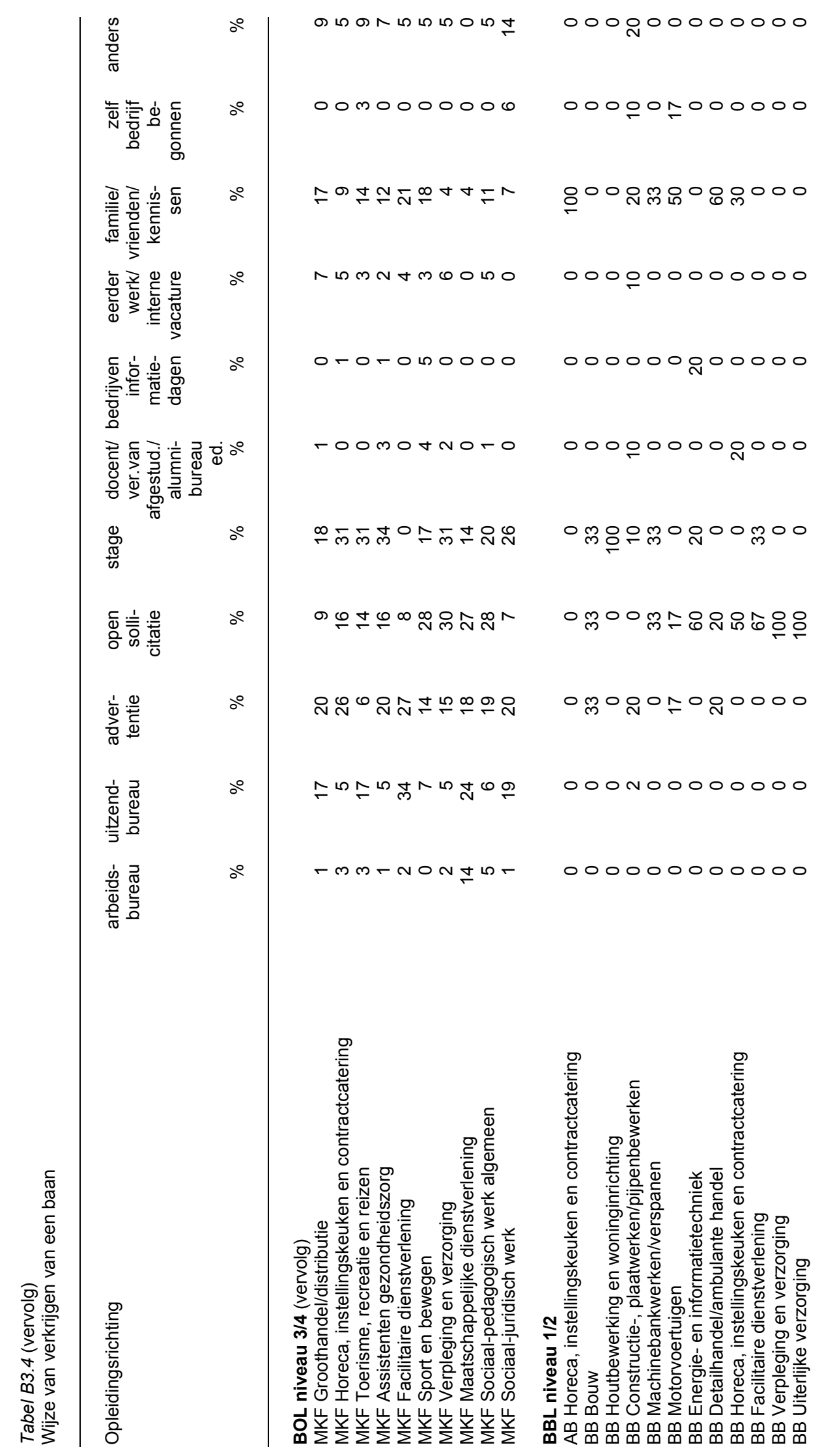




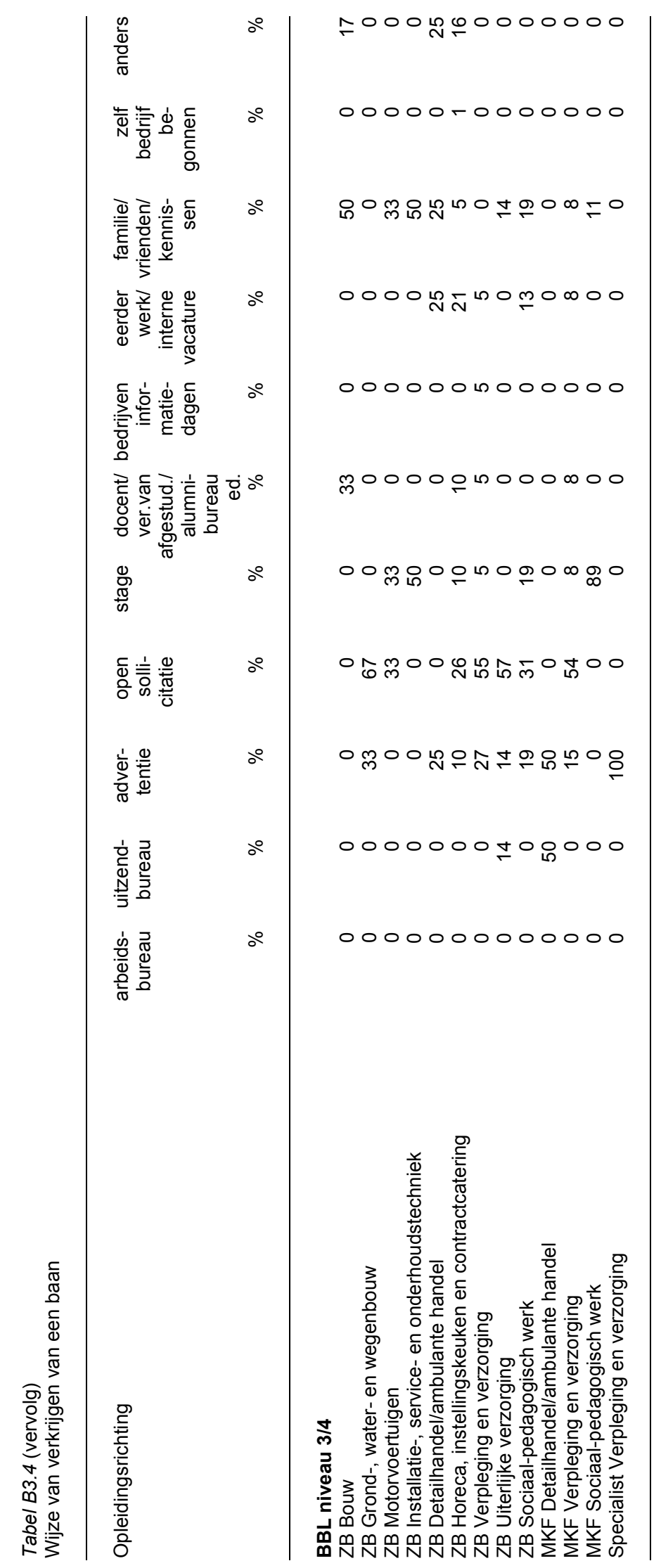


Tabel B3.5

Belangrijkste bedrijfsgroepen waarin schoolverlaters werkzaam zijn

IVBO Landbouw en natuurlijke omgeving

Ov. gespec. detailh. in winkel

Niet-gespec. detailh. in winkel

Dienstverl. tbv landb. (excl. veterin.dienst.)

Welzijnszorg

Bouwrijp maken terreinen

Handel in/repar. auto's (1)

Burgerl./utilit.;grond-/water-/wegenb. (excl. grondverz.)

VBO Landbouw en natuurlijke omgeving

Ov. gespec. detailh. in winkel

Niet-gespec. detailh. in winkel

Overheidsdienst.

Handel in/repar. auto's (1)

VBO Bouwtechniek

Burgerl./utilit.;grond-/water-/wegenb. (excl. grondverz.)

Afwerken gebouwen

Ov. gespec. detailh. in winkel

\section{VBO Mechanische techniek}

Oppervlaktebehandeling/ov. metaalbewerking

Ov. gespec. detailh. in winkel

Burgerl./utilit.;grond-/water-/wegenb. (excl. grondverz.)

Restaurants/cafetaria's/snackbars ed

Milieudienstverlening

Dienstverl. tbv landb. (excl. veterin.dienst.)

Vervaard. ov. prod. metaal (excl. mach./transportmid.)

Bouwinstallatie

Vervaard. landbouwmach./-werkt.

Bouwnijverheid

Café's ed

Vervoer over weg

Overheidsdienst.

VBO Elektrotechniek

Bouwinstallatie

Architecten-/ingenieurs-/ov. techn.ontw.-/teken-/adviesbur.

Vervaard. ov. elektr. mach./appar./benodigdh.

Bouwnijverheid

Ov. gespec. detailh. in winkel

Vervoer over weg

Overig onderwijs

Handel in/repar. auto's (1)

VBO Motorvoertuigentechniek

Handel in/repar. auto's (1)

Vervoer over weg

Groente-/fruitverwerking

Handel in/repar. auto's (2)

Burgerl./utilit.;grond-/water-/wegenb. (excl. grondverz.)

VBO Consumptieve techniek

Restaurants/cafetaria's/snackbars ed $\quad 32$

Hotels/pensions/conferentie-oorden $\quad 13$

$\begin{array}{lr}\text { Ov. dienstverlening } & 13\end{array}$

$\begin{array}{lr}\text { Vervaard. ov. voedingsmid. } & 9\end{array}$

Vervaard. farmac. prod. 
VBO Consumptieve techniek (vervolg)

Gespec. detailh. voed.-/genotmid. in winkel

VBO Administratie

Ov. gespec. detailh. in winkel

Niet-gespec. detailh. in winkel

Drukkerijen/aanverwante activ.

Restaurants/cafetaria's/snackbars ed

Rechtsk. dienstverl./account./belastingconsul./holdings ed

Welzijnszorg

VBO Verkoop

Niet-gespec. detailh. in winkel

Ov. gespec. detailh. in winkel

Uitgeverijen

Bouwinstallatie

Gespec. detailh. voed.-/genotmid. in winkel

Restaurants/cafetaria's/snackbars ed

Reiniging gebouwen/transportmid. ed

Welzijnszorg

VBO Verzorging

Niet-gespec. detailh. in winkel

Gezondheidszorg

Ov, dienstverlening

Textielveredeling

Handel in/repar. auto's (1)

Ov. gespec. detailh. in winkel

Restaurants/cafetaria's/snackbars ed

Vervoer over weg

Welzijnszorg

Gespec. detailh. voed.-/genotmid. in winkel

BOL AB Beveiliging

Overheidsdienst.

BOL AB Detailhandel/ambulante handel

Niet-gespec. detailh. in winkel

Ov. gespec. detailh. in winkel

Welzijnszorg

Restaurants/cafetaria's/snackbars ed

Vervaard. meubels

Gespec. detailh. voed.-/genotmid. in winkel

Verhuur personenauto's

Gezondheidszorg

\section{BOL BB Bouw}

Burgerl./utilit.;grond-/water-/wegenb. (excl. grondverz.)

Overheidsdienst.

Architecten-/ingenieurs-/ov. techn.ontw.-/teken-/adviesbur.

BOL BB Houtbewerking en woninginrichting

Vervaard. meubels

Ov. gespec. detailh. in winkel 
BOL BB Bedrijfsadministratie

Rechtsk. dienstverl./account./belastingconsul./holdings ed Niet-gespec. detailh. in winkel

Ov. gespec. detailh. in winkel

Overheidsdienst.

\section{BOL BB Beveiliging}

Overheidsdienst.

Beveiliging/opsporing

Gezondheidszorg

Niet-gespec. detailh. in winkel

BOL BB Commercieel

Niet-gespec. detailh. in winkel

Welzijnszorg

Vervaard. ov. voedingsmid.

Oppervlaktebehandeling/ov. metaalbewerking

Vervaard. mach./appar.

Vervoer over land

Verzekeringsw./pensioenfonds. (excl. verpl. soc.verzek.)

Architecten-/ingenieurs-/ov. techn.ontw.-/teken-/adviesbur.

\section{BOL BB Secretarieel}

Rechtsk. dienstverl./account./belastingconsul./holdings ed

Niet-gespec. detailh. in winkel

Verzekeringsw./pensioenfonds. (excl. verpl. soc.verzek.)

Uitzendbur./uitleenbedr./arbeidsbemid./testen/werven/select.

Welzijnszorg

Vervaard. ov. mach./appar. voor alg. gebr.

Gespec. detailh. voed.-/genotmid. in winkel

Geldscheppende financ. instell.

Architecten-/ingenieurs-/ov. techn.ontw.-/teken-/adviesbur.

Ov. zakelijke dienstverl. n.e.g.

BOL BB Detailhandel/ambulante handel

Niet-gespec. detailh. in winkel

Ov. gespec. detailh. in winkel

Overheidsdienst.

BOL BB Horeca, instellingskeuken en contractcatering Restaurants/cafetaria's/snackbars ed

Ov. gespec. detailh. in winkel

Welzijnszorg

Overheidsdienst.

Grooth. voedings-/genotmid.

Vervaard. metalen constructiew./ramen/deuren/kozijnen

BOL BB Facilitaire dienstverlening

Restaurants/cafetaria's/snackbars ed

Kantines/catering

Welzijnszorg

Ov. gespec. detailh. in winkel

Gezondheidszorg

Vervaard. ov. mach./appar. voor specif. ind. activ.

Niet-gespec. detailh. in winkel

Basisonderwijs voor leerplichtingen/speciaal onderwijs 
BOL BB Verpleging en verzorging (vervolg)

Gezondheidszorg

Restaurants/cafetaria's/snackbars ed

BOL ZB Plantenteelt

Akker-/tuinbouw

Natuurwet. speur-/ontwikkelingsw.

Ov. gespec. detailh. in winkel

Dienstverl. tbv landb. (excl. veterin.dienst.)

Bouwrijp maken terreinen

Grooth. landbouwprod./lev. dieren

Sport

BOL ZB Veehouderij

Ov. gespec. detailh. in winkel 19

Fokken/houden dieren 15

Dienstverl. tbv landb. (excl. veterin.dienst.)

Oppervlaktebehandeling/ov. metaalbewerking

Openbaar bestuur

Veterinaire diensten

BOL ZB Bloemschikken

Ov. gespec. detailh. in winkel

BOL ZB Groene ruimte

Dienstverl. tbv landb. (excl. veterin.dienst.)

Openbaar bestuur

Milieudienstverlening

BOL ZB Scheepvaart

Vervoer over water

Zeevaart

Openbaar bestuur

Visserij/kweken vis/schaaldieren

Zand-/grind-/kleiwinning

Binnenvaart

Overheidsdienst.

BOL ZB Bedrijfsadministratief

Rechtsk. dienstverl./account./belastingconsul./holdings ed

Vervaard. keram. tegels/plavuizen

Vervaard. mach./appar.

Prod./distrib. elektriciteit/aardgas/stoom/warm water

Grooth. ov. consumentenart.

Hotels/pensions/conferentie-oorden

Onderhoud/repar. computers/kantoormach.

Openbaar bestuur

Telecommunicatie

Overheidsdienst.

BOL ZB Secretarieel

Verpl. soc. verzekeringen

Ov. gespec. detailh. in winkel

Verzekeringsw./pensioenfonds. (excl. verpl. soc.verzek.)

Rechtsk. dienstverl./account./belastingconsul./holdings ed

Reisorgan./-bemid.;informatieverstrek. op gebied toerisme

Natuurwet. speur-/ontwikkelingsw.

Voortgezet onderwijs

Hoger onderwijs

Welzijnszorg 
BOL ZB Detailhandel/ambulante handel

Ov. gespec. detailh. in winkel

Detailh. farmac./med. art./parfum/cosmet. in winkel

Rechtsk. dienstverl./account./belastingconsul./holdings ed

Vervaard. gereedschapswerkt.

Handel in/repar. auto's (1)

Architecten-/ingenieurs-/ov. techn.ontw.-/teken-/adviesbur.

BOL ZB Verpleging en verzorging

Gezondheidszorg

BOL ZB Uiterlijke verzorging

Ov. dienstverlening

Detailh. farmac./med. art./parfum/cosmet. in winkel

BOL KF Plantenteelt

Akker-/tuinbouw

Dienstverl. tbv landb. (excl. veterin.dienst.)

Grooth. landbouwprod./lev. dieren

Natuurwet. speur-/ontwikkelingsw.

BOL KF Veehouderij

Veterinaire diensten

Fokken/houden dieren

Dienstverl. tbv landb. (excl. veterin.dienst.)

Landb./jacht/dienstverl. tbv landb./jacht

Ov. gespec. detailh. in winkel

Akker-/tuinbouw

Akker- en/of tuinb. comb. met fokken/houden dieren

\section{BOL KF Bloemschikken}

Ov. gespec. detailh. in winkel

Grooth. intermediaire goederen (excl. agrar.)/afval/schroot

Architecten-/ingenieurs-/ov. techn.ontw.-/teken-/adviesbur.

BOL KF Groene ruimte

Dienstverl. tbv landb. (excl. veterin.dienst.)

Ov. gespec. detailh. in winkel

Overheidsdienst.

BOL KF Milieutoezicht

Openbaar bestuur

Architecten-/ingenieurs-/ov. techn.ontw.-/teken-/adviesbur.

Milieudienstverlening

Rechtsk. dienstverl./account./belastingconsul./holdings ed

Verhuur onroerend goed

BOL MKF Bouw

Burgerl./utilit.;grond-/water-/wegenb. (excl. grondverz.)

Architecten-/ingenieurs-/ov. techn.ontw.-/teken-/adviesbur.

Bouwnijverheid

Openbaar bestuur

BOL MKF Houtbewerking en woninginrichting

Vervaard. meubels

Ov. gespec. detailh. in winkel

Scheepsbouw/-reparatie

Reklamebureaus ed

Ov. zakelijke dienstverl. n.e.g. 


\section{BOL MKF Grond-, water- en wegenbouw}

Burgerl./utilit.;grond-/water-/wegenb. (excl. grondverz.) 40

Architecten-/ingenieurs-/ov. techn.ontw.-/teken-/adviesbur. 32

Openbaar bestuur 12

Uitzendbur./uitleenbedr./arbeidsbemid./testen/werven/select. $\quad 6$

BOL MKF Beschermings- en afwerkingstechnieken

Afwerken gebouwen

Ov. gespec. detailh. in winkel

Reklamebureaus ed

Vervaard. glas/aardew./cement-/kalk-/gipsprod.

Vervaard. med. appar./instrum./orthop./prothese-art.

Vervaard. meubels

Restaurants/cafetaria's/snackbars ed

BOL MKF Reclame, presentatie en communicatie

Ov. gespec. detailh. in winkel

Reklamebureaus ed

BOL MKF Werktuigbouwkunde

Architecten-/ingenieurs-/ov. techn.ontw.-/teken-/adviesbur.

Vervaard. mach./appar.

Scheepsbouw/-reparatie

Burgerl./utilit.;grond-/water-/wegenb. (excl. grondverz.)

Overheidsdienst.

BOL MKF Motorvoertuigen

Handel in/repar. auto's (1)

Handel in/repar. auto's (2)

Ov. gespec. detailh. in winkel

BOL MKF Energie- en informatietechniek

Bouwinstallatie

Telecommunicatie

Architecten-/ingenieurs-/ov. techn.ontw.-/teken-/adviesbur.

Grooth. mach./appar./toebehoren

BOL MKF Informatietechniek

Telecommunicatie

Adviesbur. op gebied automat./systeemh.

Uitzendbur./uitleenbedr./arbeidsbemid./testen/werven/select.

BOL MKF Graf. techn, communicatie, audiovisueel en multimedia

Reklamebureaus ed

Drukkerijen/aanverwante activ.

Systeemontwikkelings-/systeemanalyse-/programmeerdienst.

Vervaard. glas/glaswerk

Vervaard. huish. appar.

Handel auto-onderd./-accessoir.

Overig amusement/kunst

BOL MKF Laboratoriumtechniek

Gezondheidszorg

Vervaard. basischemicalien

BOL MKF Scheepvaart

Aardolieverw.

Scheepsbouw/-reparatie

Burgerl./utilit.;grond-/water-/wegenb. (excl. grondverz.) 
BOL MKF Scheepvaart (vervolg)

Vervoer over water

Reisorgan./-bemid.;informatieverstrek. op gebied toerisme

BOL MKF Transport en logistiek

Vervoer door lucht

Ov. dienstverl. tbv verv. n.e.g.

Expedit./cargad./bevracht.;weging/meting

Dienstverl. tbv vervoer

Laad-/los-/overslagactiv./opslag

BOL MKF Bedrijfsadministratief

Rechtsk. dienstverl./account./belastingconsul./holdings ed

BOL MKF Commercieel

Verzekeringsw./pensioenfonds. (excl. verpl. soc.verzek.)

Geldscheppende financ. instell.

Rechtsk. dienstverl./account./belastingconsul./holdings ed

Activ. verzekeringsw./pensioenfonds.

Grooth. ov. consumentenart.

BOL MKF Economisch-juridisc

Rechtsk. dienstverl./account./belastingconsul./holdings ed

Verpl. soc. verzekeringen

Openbaar bestuur

Overheidsdienst.

Telecommunicatie

Geldscheppende financ. instell.

BOL MKF Secretarieel

Rechtsk. dienstverl./account./belastingconsul./holdings ed Overheidsdienst.

BOL MKF Detailhandel/ambulante handel

Ov. gespec. detailh. in winkel

Niet-gespec. detailh. in winkel

Detailh. farmac./med. art./parfum/cosmet. in winkel

BOL MKF Groothandel/distributie

Grooth. ov. consumentenart.

Geldscheppende financ. instell.

Handel in/repar. auto's (1)

Gespec. detailh. voed.-/genotmid. in winkel

Ov. gespec. detailh. in winkel

Repar. tbv partic. (niet auto's/motorfiets.)

Post-/koeriersdiensten

Uitzendbur./uitleenbedr./arbeidsbemid./testen/werven/select.

Ov. zakelijke dienstverl. n.e.g.

BOL MKF Horeca, instellingskeuken en contractcatering Hotels/pensions/conferentie-oorden

Restaurants/cafetaria's/snackbars ed

BOL MKF Toerisme, recreatie en reizen

Reisorgan./-bemid.;informatieverstrek. op gebied toerisme Hotels/pensions/conferentie-oorden 
BOL MKF Toerisme, recreatie en reizen (vervolg)

Kampeerterreinen/ov. voorzien. recreat. verblijf n.e.g.

Ov. dienstverl. tbv verv. n.e.g.

BOL MKF Assistenten gezondheidszorg

Gezondheidszorg

Detailh. farmac./med. art./parfum/cosmet. in winkel

BOL MKF Facilitaire dienstverlening

Restaurants/cafetaria's/snackbars ed

Openbaar bestuur

Grooth. ov. consumentenart.

Ov. gespec. detailh. in winkel

Hotels/pensions/conferentie-oorden

Geldscheppende financ. instell.

BOL MKF Sport en bewegen

Sport

Overheidsdienst.

Welzijnszorg

Overig amusement/kunst

BOL MKF Verpleging en verzorging

Gezondheidszorg

BOL MKF Maatschappelijke dienstverlening

Verzekeringsw./pensioenfonds. (excl. verpl. soc.verzek.)

$\begin{array}{ll}\text { Verpl. soc. verzekeringen } & 24 \\ \text { Overheisdienst } & 24\end{array}$

Overheidsdienst.

Restaurants/cafetaria's/snackbars ed

Openbaar bestuur

Hoger onderwijs

Gezondheidszorg

Welzijnszorg

BOL MKF Sociaal-pedagogisch werk algemeen

Welzijnszorg

Gezondheidszorg

BOL MKF Sociaal-juridisch werk

Verpl. soc. verzekeringen

Overheidsdienst.

Uitzendbur./uitleenbedr./arbeidsbemid./testen/werven/select.

Vervaard. med. appar./instrum./orthop. art. ed/uurw.

Prod./distrib. elektriciteit/aardgas/stoom/warm water

Restaurants/cafetaria's/snackbars ed

Geldscheppende financ. instell.

Verzekeringsw./pensioenfonds. (excl. verpl. soc.verzek.)

Voortgezet onderwijs

Welzijnszorg

BBL AB Beveiliging

Openbaar bestuur

Beveiliging/opsporing

Overheidsdienst.

Hotels/pensions/conferentie-oorden

Activ. tbv of verwant aan financ. instell. (niet verzek. ed)

Reiniging gebouwen/transportmid. ed 
BBL AB Horeca, instellingskeuken en contractcatering

Dienstverl. tbv landb. (excl. veterin.dienst.)

Vervaard. ov. goederen n.e.g.

Grooth. voedings-/genotmid.

Restaurants/cafetaria's/snackbars ed $\quad 31$

Kantines/catering $r$

Ov. gespec. detailh. in winkel

Kampeerterreinen/ov. voorzien. recreat. verblijf n.e.g.

\section{BBL BB Plantenteelt}

Akker-/tuinbouw

Vervaard. landbouwmach./-werkt.

\section{BBL BB Bloemschikken}

Ov. gespec. detailh. in winkel

Ov. dienstverlening

Akker-/tuinbouw

BBL BB Groene ruimte

Dienstverl. tbv landb. (excl. veterin.dienst.)

Vervaard. ov. goederen n.e.g.

Akker-/tuinbouw

\section{BBL BB Bouw}

Burgerl./utilit.;grond-/water-/wegenb. (excl. grondverz.)

BBL BB Houtbewerking en woninginrichting

Vervaard. meubels

Scheepsbouw/-reparatie

BBL BB Constructie-, plaatwerken/pijpenbewerken

Vervaard. metalen constructiew./ramen/deuren/kozijnen

Architecten-/ingenieurs-/ov. techn.ontw.-/teken-/adviesbur.

Scheepsbouw/-reparatie

Burgerl./utilit.;grond-/water-/wegenb. (excl. grondverz.)

Vervaard. mach./appar.

BBL BB Machinebankwerken/verspanen

Vervaard. prod. metaal (excl. mach./transportmid.)

Vervaard. scharen/bestek/gereedsch./hang-/sluitw.

Vervaard. mach./appar.

Vervaard. glas/aardew./cement-/kalk-/gipsprod.

Vervaard. ov. prod. metaal (excl. mach./transportmid.)

Vervaard. mach.prod./toepas.mech.energ.(excl.motorvoert.ed)

Vervaard. landbouwmach./-werkt.

Vervaard. gereedschapswerkt.

Vervaard. elektr. componenten

Vervaard. med. appar./instrum./orthop. art. ed/uurw.

Rechtsk. dienstverl./account./belastingconsul./holdings ed

BBL BB Motorvoertuigen

Handel in/repar. auto's (1)

Ov. gespec. detailh. in winkel

BBL BB Energie- en informatietechniek 
BBL BB Energie- en informatietechniek (vervolg)

Vervaard. kantoormachines/computers

Vervaard. ov. elektr. benodigdh. n.e.g.

Grooth. intermediaire goederen (excl. agrar.)/afval/schroot

Vervaard. ov. mach./appar. voor specif. ind. activ.

Vervaard. schakel-/verdeelinricht.

Vervoer over weg

BBL BB Installatie-, service- en onderhoudstechniek

Bouwinstallatie

Burgerl./utilit.;grond-/water-/wegenb. (excl. grondverz.)

Ov. gespec. detailh. in winkel

Architecten-/ingenieurs-/ov. techn.ontw.-/teken-/adviesbur.

BBL BB Graf. techn, communicatie, audiovisueel en multimedia Drukkerijen/aanverwante activ.

Uitzendbur./uitleenbedr./arbeidsbemid./testen/werven/select.

\section{BBL BB Wegvervoer}

Vervoer over weg

Expedit./cargad./bevracht.;weging/meting

Dienstverl. tbv vervoer

Grooth. voedings-/genotmid.

Milieudienstverlening

\section{BBL BB Detailhandel/ambulante handel}

Ov. gespec. detailh. in winkel

Niet-gespec. detailh. in winkel

Detailh. farmac./med. art./parfum/cosmet. in winkel

Gespec. detailh. voed.-/genotmid. in winkel

BBL BB Opslag/magazijn

Ov. gespec. detailh. in winkel

Grooth. voedings-/genotmid.

Grooth. ov. consumentenart.

Gezondheidszorg

Vervoer over weg

BBL BB Horeca, instellingskeuken en contractcatering

Restaurants/cafetaria's/snackbars ed

Hotels/pensions/conferentie-oorden

Gezondheidszorg

BBL BB Facilitaire dienstverlening

Welzijnszorg

Gezondheidszorg

Ov. gespec. detailh. in winkel

Niet-gespec. detailh. in winkel

BBL BB Verpleging en verzorging

Welzijnszorg

BBL BB Uiterlijke verzorging

Ov. dienstverlening 
BBL ZB Bloemschikken

Ov. gespec. detailh. in winkel

BBL ZB Groene ruimte

Dienstverl. tbv landb. (excl. veterin.dienst.)

Openbaar bestuur $\quad 32$

Akker-/tuinbouw 14

BBL ZB Bouw

Burgerl./utilit.;grond-/water-/wegenb. (excl. grondverz.)

Bouwnijverheid

BBL ZB Grond-, water- en wegenbouw

Burgerl./utilit.;grond-/water-/wegenb. (excl. grondverz.)

$\begin{array}{ll}\text { Bouwrijp maken terreinen } & 43\end{array}$

Verhuur bouw-/sloopmachines met bedienend personeel 11

Verhuur machines/werkt.

BBL ZB Beschermings- en afwerkingstechnieken

Afwerken gebouwen

Burgerl./utilit.;grond-/water-/wegenb. (excl. grondverz.)

BBL ZB Motorvoertuigen

Handel in/repar. auto's (1)

BBL ZB Beheer, ontwerp en management (instal. techn)

Bouwinstallatie

Architecten-/ingenieurs-/ov. techn.ontw.-/teken-/adviesbur.

Grooth. mach./appar./toebehoren

Vervaard. mach./appar.

Vervaard. ov. mach./appar. voor alg. gebr.

Handel in/repar. auto's (1)

Overheidsdienst.

BBL ZB Installatie-, service- en onderhoudstechniek

BBL ZB Procestechniek

Vervaard. chem. prod.

Bouwinstallatie

Vervaard. prod. kunststof

Vervaard. farmac. prod.

Vervaard. prod. metaal (excl. mach./transportmid.)

Vervaard. basischemicalien

Vervaard. auto's

Gespec. detailh. voed.-/genotmid. in winkel

Systeemontwikkelings-/systeemanalyse-/programmeerdienst.

BBL ZB Detailhandel/ambulante handel

Ov. gespec. detailh. in winkel

BBL ZB Horeca, instellingskeuken en contractcatering

Restaurants/cafetaria's/snackbars ed

Hotels/pensions/conferentie-oorden

Kantines/catering

Niet-gespec. detailh. in winke

Afwerken gebouwen 
BBL ZB Horeca, instellingskeuken en contractcatering (vervolg)

Logies-/maaltijden-/drankenverstrek.

BBL ZB Verpleging en verzorging

Welzijnszorg

BBL ZB Uiterlijke verzorging

Ov. dienstverlening

Geldscheppende financ. instell.

BBL ZB Sociaal-pedagogisch werk

Welzijnszorg

BBL MKF Detailhandel/ambulante handel

Ov. gespec. detailh. in winkel

Niet-gespec. detailh. in winke

Telecommunicatie

BBL MKF Horeca, instellingskeuken en contractcatering

Restaurants/cafetaria's/snackbars ed

Hotels/pensions/conferentie-oorden

Cafés ed

Kantines/catering

Post-/koeriersdiensten

BBL MKF Verpleging en verzorging

Gezondheidszorg

BBL MKF Sociaal-pedagogisch werk Welzijnszorg

BBL Specialist Energietechniek

Bouwinstallatie

Prod./distrib. elektriciteit/aardgas/stoom/warm water

Adviesbur. op gebied automat./systeemh.

BBL Specialist Verpleging en verzorging

Welzijnszorg

Zie toelichting bladzijde 32 
Tabel B3.6

Belangrijkste beroepsgroepen waarin schoolverlaters werkzaam zijn

IVBO Landbouw en natuurlijke omgeving

Verkopers

Interieurverzorger

Agrarische arbeider

Monteurs

Hulpkrachten horeca en verzorging

VBO Landbouw en natuurlijke omgeving

Verkopers

Hulpkrachten horeca en verzorging

Laders en lossers

Agrarische arbeider

Assembleurs

Receptionisten en administratieve employés

VBO Bouwtechniek

Bouwvakkers

Verkopers

Aannemers en installateurs

VBO Mechanische techniek

Metaalarbeiders

Hulpkrachten horeca en verzorging

Laders en lossers

Weg- en waterbouwkundige arbeiders

Confectie-arbeiders

Bouwvakkers

Bankwerkers en lassers

Assembleurs

Chauffeurs

Aspirant politieagenten, soldaten en beveiligingshulpkrachten

Agrarische vakkrachten

Aannemers en installateurs

VBO Elektrotechniek

Monteurs en controleurs elektrotechnische producten $\quad 47$

Monteurs

Laders en lossers

Assembleurs

Elektromonteurs

Interieurverzorger

VBO Motorvoertuigentechniek

Assembleurs

Monteurs

Productiemedewerker

Laders en lossers

VBO Consumptieve techniek

Hulpkrachten horeca en verzorging $\quad 39$

Verzorgend personeel $\quad 27$

$\begin{array}{lr}\text { Bakkers en slagers } & 18\end{array}$

$\begin{array}{lr}\text { Interieurverzorger } & 9\end{array}$

\section{VBO Administratie}

Verkopers

Receptionisten en administratieve employés 
VBO Administratie (vervolg)

Interieurverzorger

Hulpkrachten horeca en verzorging

Grafisch productiepersoneel

Mechanisch operators

Verzorgend personeel

\section{VBO Verkoop}

Verkopers

Hulpkrachten horeca en verzorging

Interieurverzorger

Bouwvakkers

Mechanisch operators

Receptionisten en administratieve employés

Winkeliers

\section{VBO Verzorging}

Verkopers

Verzorgend personeel

Interieurverzorger

Productiemedewerker

Laders en lossers

Vakkenvuller

Hulpkrachten horeca en verzorging

BOL AB Beveiliging

Aspirant politieagenten, soldaten en beveiligingshulpkrachten Politieagenten, onderofficieren en beveiligingsemployés

Kantoorhulpen, inpakkers en colporteurs

Verkopers

BOL AB Detailhandel/ambulante handel

Verkopers

Hulpkrachten horeca en verzorging

Bouwvakkers

Verpleeghulpen en leerling-verpleegkundigen

Receptionisten en administratieve employés

Technisch-bedrijfskundig medewerkers

BOL BB Bouw

Aannemers en installateurs

BOL BB Houtbewerking en woninginrichting

Aannemers en installateurs

$\begin{array}{ll}\text { Receptionisten en administratieve employés } & 10\end{array}$

Confectie-arbeiders

BOL BB Bedrijfsadministratie

Boekhouders en secretaresses

Receptionisten en administratieve employés

BOL BB Beveiliging

Aspirant politieagenten, soldaten en beveiligingshulpkrachten 
BOL BB Commercieel

Receptionisten en administratieve employés $\quad 24$

Verkopers

Verzorgend personeel

Boekhouders en secretaresses

Vakkenvuller

BOL BB Secretarieel

Receptionisten en administratieve employés 38

$\begin{array}{ll}\text { Boekhouders en secretaresses } & 19\end{array}$

Verkopers 13

Commercieel employés $\quad 12$

Verzekeringsagenten $\quad 5$

Elektromonteurs $\quad 5$

$\begin{array}{ll}\text { Activiteitenbegeleiders en medewerkers arbeidsbemiddeling } & 5\end{array}$

BOL BB Detailhandel/ambulante handel

Verkopers

Aspirant politieagenten, soldaten en beveiligingshulpkrachten

Receptionisten en administratieve employés

BOL BB Horeca, instellingskeuken en contractcatering

Hulpkrachten horeca en verzorging

Verzorgend personeel

Metaalarbeiders

Verkopers

Bedrijfshoofden horeca

Laders en lossers

Confectie-arbeiders

BOL BB Facilitaire dienstverlening

Hulpkrachten horeca en verzorging

Interieurverzorger

Verkopers

Kantoorhulpen, inpakkers en colporteurs

Mechanisch operators

BOL BB Verpleging en verzorging

Verzorgend personeel

Ziekenverzorgenden

Hulpkrachten horeca en verzorging

Interieurverzorger

Verkopers

Verplegenden en doktersassistenten

\section{BOL ZB Plantenteelt}

Agrarische arbeider

Weg- en waterbouwkundige vakkrachten

Landbouwmachinebestuurders en vissers

Agrarische bedrijfshoofden

Laders en lossers

Ondersteunende administratieve hulpkrachten

Chauffeurs

Verkopers

BOL ZB Veehouderij

Agrarische arbeider

Verkopers

Mechanisch operators

Chauffeurs 
BOL ZB Veehouderij (vervolg)

Metaalarbeiders

Weg- en waterbouwkundige vakkrachten

BOL ZB Bloemschikken

Verkopers

Agrarische vakkrachten

Hulpkrachten horeca en verzorging

Receptionisten en administratieve employés

Aspirant politieagenten, soldaten en beveiligingshulpkrachten

BOL ZB Groene ruimte

Agrarische bedrijfshoofden

Agrarische arbeider

Verkopers

Laders en lossers

BOL ZB Scheepvaart

Schippers en conducteurs $\quad 24$

\begin{tabular}{ll} 
Assembleurs & 24 \\
\hline
\end{tabular}

Chauffeurs $\quad 15$

$\begin{array}{lr}\text { Landbouwmachinebestuurders en vissers } & 9\end{array}$

Monteurs

Agrarische arbeider

Hulpkrachten horeca en verzorging

Weg- en waterbouwkundige vakkrachten

\section{BOL ZB Bedrijfsadministratief}

Boekhouders en secretaresses

Juridisch en fiscaal medewerkers

Receptionisten en administratieve employés

Bibliotheekassistenten

BOL ZB Secretarieel

Boekhouders en secretaresses

Receptionisten en administratieve employés

Commercieel employés

Verzekeringsagenten

Medisch secretaresses

BOL ZB Detailhandel/ambulante handel

Verkopers

Receptionisten en administratieve employés

Boekhouders en secretaresses

Winkeliers

Activiteitenbegeleiders en medewerkers arbeidsbemiddeling

BOL ZB Verpleging en verzorging

Verzorgend personeel

Verplegenden en doktersassistenten

Ziekenverzorgenden

Verpleeghulpen en leerling-verpleegkundigen

Hulpkrachten horeca en verzorging

BOL ZB Uiterlijke verzorging

Verzorgend personeel 
BOL KF Plantenteelt

Agrarische arbeider

Agrarische bedrijfshoofden

Landbouwmachinebestuurders en vissers

Verkopers

BOL KF Veehouderij

Agrarische arbeider

Verkopers

Verplegenden en doktersassistenten

Agrarische bedrijfshoofden

Bouwvakkers

\section{BOL KF Bloemschikken}

Verkopers

Agrarische vakkrachten

Agrarische arbeider

Productieplanners

BOL KF Groene ruimte

Agrarische bedrijfshoofden

Agrarische arbeider

Productieplanners

Brandweerlieden

BOL KF Milieutoezicht

Milieuhygienisten en agrarisch vertegenwoordigers

Boekhouders en secretaresses

Aspirant politieagenten, soldaten en beveiligingshulpkrachten

Aannemers en installateurs

BOL MKF Bouw

Aannemers en installateurs

BOL MKF Houtbewerking en woninginrichting

Aannemers en installateurs

Verkopers

Bouwvakkers

Technisch-commercieel employés

Confectie-arbeiders

BOL MKF Grond-, water- en wegenbouw

Weg- en waterbouwkundige vakkrachten

BOL MKF Beschermings- en afwerkingstechnieken

Bouwvakkers

Verkopers

Metaalarbeiders

Mechanisch operators

Confectie-arbeiders

Productieplanners

Commercieel employés

Architecten en bouwkundig projectleiders

Hulpkrachten horeca en verzorging

Technisch-commercieel employés 
BOL MKF Reclame, presentatie en communicatie

Technisch-commercieel employés

Grafisch ontwerpers

Grafisch productiepersoneel

Verkopers

Winkeliers

BOL MKF Werktuigbouwkunde

Monteurs

Aannemers en installateurs

Elektromonteurs

BOL MKF Motorvoertuigen

Monteurs

Boekhouders en secretaresses

Elektromonteurs

BOL MKF Energie- en informatietechniek

Elektromonteurs

Elektronicamonteurs

Monteurs en controleurs elektrotechnische producten

Programmeurs

BOL MKF Informatietechniek

Programmeurs

Elektromonteurs

Systeemanalisten

Monteurs en controleurs elektrotechnische producten

BOL MKF Graf. techn, communicatie, audiovisueel en multimedia

Grafisch ontwerpers

Commercieel employés

Productieplanners

Boekhouders en secretaresses

Programmeurs

Mechanisch operators

Administratieve transportemployés

BOL MKF Laboratoriumtechniek

Apothekersassistenten en medisch laboranten 38

Laboranten

Procesoperators

BOL MKF Scheepvaart

Monteurs

Schippers en conducteurs

Vliegers, scheepskapiteins en leidinggevenden transport

Politie-inspecteurs en officieren

BOL MKF Transport en logistiek

Productieplanners

Commercieel employés

Stewards

Administratieve transportemployés

Receptionisten en administratieve employés

BOL MKF Bedrijfsadministratief

Boekhouders en secretaresses 
BOL MKF Bedrijfsadministratief (vervolg)

Receptionisten en administratieve employés

Hulpkrachten horeca en verzorging

Assistent accountants

BOL MKF Commercieel

Commercieel employés

Receptionisten en administratieve employés

Boekhouders en secretaresses

Verzekeringsagenten

BOL MKF Economisch-juridisch

Boekhouders en secretaresses

Commercieel employés

Juridisch en fiscaal medewerkers

BOL MKF Secretarieel

Boekhouders en secretaresses

Receptionisten en administratieve employés

Commercieel employés

BOL MKF Detailhandel/ambulante handel

Verkopers

Winkeliers

Boekhouders en secretaresses

Receptionisten en administratieve employés

Commercieel employés

BOL MKF Groothandel/distributie

Commercieel employés

Receptionisten en administratieve employés

Receptionisten en administratieve employés
Boekhouders en secretaresses

Productieplanners

Programmeurs

Chauffeurs

Activiteitenbegeleiders en medewerkers arbeidsbemiddeling

Procestechnologen

Commercieel medewerkers

BOL MKF Horeca, instellingskeuken en contractcatering Verzorgend personeel

Receptionisten en administratieve employés

Hulpkrachten horeca en verzorging

Boekhouders en secretaresses

Bedrijfshoofden horeca

Commercieel employés

BOL MKF Toerisme, recreatie en reizen

Commercieel employés

Receptionisten en administratieve employés

Boekhouders en secretaresses

BOL MKF Assistenten gezondheidszorg

Apothekersassistenten en medisch laboranten

Verplegenden en doktersassistenten

BOL MKF Facilitaire dienstverlening

Receptionisten en administratieve employés 
BOL MKF Facilitaire dienstverlening (vervolg)

Commercieel employés

Verkopers

Productieplanners

Laders en lossers

Boekhouders en secretaresses

BOL MKF Sport en bewegen

Sportinstructeurs

Activiteitenbegeleiders en medewerkers arbeidsbemiddeling

BOL MKF Verpleging en verzorging

Verplegenden en doktersassistenten

Verzorgend personeel

BOL MKF Maatschappelijke dienstverlening

Boekhouders en secretaresses

Activiteitenbegeleiders en medewerkers arbeidsbemiddeling

Commercieel employés

Verzorgend personeel

Bedrijfshoofden horeca

Sociaal-cultureel werkers

BOL MKF Sociaal-pedagogisch werk algemeen

Verzorgend personeel

Activiteitenbegeleiders en medewerkers arbeidsbemiddeling

Hulpkrachten horeca en verzorging

BOL MKF Sociaal-juridisch werk

Boekhouders en secretaresses

Receptionisten en administratieve employés

Activiteitenbegeleiders en medewerkers arbeidsbemiddeling

Aspirant politieagenten, soldaten en beveiligingshulpkrachten

Commercieel employés

Verzorgend personeel

Bedrijfshoofden horeca

Assistent accountants

BBL AB Beveiliging

Aspirant politieagenten, soldaten en beveiligingshulpkrachten

Kantoorhulpen, inpakkers en colporteurs

Receptionisten en administratieve employés

BBL AB Horeca, instellingskeuken en contractcatering

Mechanisch operators

Verzorgend personeel

Interieurverzorger

Verkopers

Hulpkrachten horeca en verzorging

Laders en lossers

Agrarische arbeider

Chauffeurs

Bedrijfshoofden horeca

BBL BB Plantenteelt

Agrarische arbeider 
BBL BB Plantenteelt (vervolg)

Agrarische hulparbeider

BBL BB Bloemschikken

Verkopers

Receptionisten en administratieve employés

BBL BB Groene ruimte

Agrarische arbeider

Agrarische bedrijfshoofden

BBL BB Bouw

Bouwvakkers

Aannemers en installateurs

BBL BB Houtbewerking en woninginrichting

Bouwvakkers

Aannemers en installateurs

BBL BB Constructie-, plaatwerken/pijpenbewerken

Metaalarbeiders

Bankwerkers en lassers

Aannemers en installateurs

Bouwvakkers

BBL BB Machinebankwerken/verspanen

Metaalarbeiders

Bankwerkers en lassers

Monteurs

Monteurs en controleurs elektrotechnische producten

BBL BB Motorvoertuigen

Monteurs

Assembleurs

Winkeliers

BBL BB Energie- en informatietechniek

Elektromonteurs

Elektronicamonteurs

Monteurs en controleurs elektrotechnische producten

Assembleurs

Aannemers en installateurs

BBL BB Installatie-, service- en onderhoudstechniek

Aannemers en installateurs

BBL BB Graf. techn, communicatie, audiovisueel en multimedia

Grafisch productiepersoneel

Grafische vakkrachten

Grafisch ontwerpers

Productiemedewerker

Technisch systeemanalisten

BBL BB Wegvervoer

Chauffeurs

Laders en lossers

BBL BB Detailhandel/ambulante handel 
BBL BB Detailhandel/ambulante handel (vervolg)

Winkeliers

Receptionisten en administratieve employés

BBL BB Opslag/magazijn

Laders en lossers

Chauffeurs

Boekhouders en secretaresses

Commercieel employés

BBL BB Horeca, instellingskeuken en contractcatering

Verzorgend personeel

Hulpkrachten horeca en verzorging

Interieurverzorger

BBL BB Facilitaire dienstverlening

Hulpkrachten horeca en verzorging

Verzorgend personeel

Kantoorhulpen, inpakkers en colporteurs

Winkeliers

BBL BB Verpleging en verzorging

Verzorgend personeel

Hulpkrachten horeca en verzorging

Ziekenverzorgenden

Verpleeghulpen en leerling-verpleegkundigen

BBL BB Uiterlijke verzorging

Verzorgend personeel

Hulpkrachten horeca en verzorging

BBL ZB Bloemschikken

Verkopers

Winkeliers

Agrarische vakkrachten

BBL ZB Groene ruimte

Agrarische bedrijfshoofden

Agrarische arbeider

BBL ZB Bouw

Aannemers en installateurs

BBL ZB Grond-, water- en wegenbouw

Weg- en waterbouwkundige vakkrachten

Weg- en waterbouwkundige arbeiders

Monteurs

Chauffeurs

Productiemedewerker

BBL ZB Beschermings- en afwerkingstechnieken

Bouwvakkers

Aannemers en installateurs

BBL ZB Motorvoertuigen

BBL ZB Beheer, ontwerp en management (instal. techn) 
BBL ZB Beheer, ontwerp en management (instal. techn) (vervolg)

Technisch-commercieel employés

Monteurs

Bouwvakkers

Hoofden technische dienst

Elektromonteurs

Systeemanalisten

BBL ZB Installatie-, service- en onderhoudstechniek

Aannemers en installateurs

Monteurs

Bouwvakkers

BBL ZB Procestechniek

Procesoperators

Mechanisch operators

Bouwvakkers

Monteurs

Elektromonteurs

Programmeurs

BBL ZB Detailhandel/ambulante handel

Verkopers

Winkeliers

Receptionisten en administratieve employés

Commercieel employés

BBL ZB Horeca, instellingskeuken en contractcatering

Verzorgend personeel

Hulpkrachten horeca en verzorging

Verkopers

Bouwvakkers

BBL ZB Verpleging en verzorging

Ziekenverzorgenden

Verzorgend personeel

Hulpkrachten horeca en verzorging

BBL ZB Uiterlijke verzorging

Verzorgend personeel

Hulpkrachten horeca en verzorging

Commercieel employés

BBL ZB Sociaal-pedagogisch werk

Verzorgend personeel

BBL MKF Detailhandel/ambulante handel

Winkeliers

Verkopers

Receptionisten en administratieve employés

BBL MKF Horeca, instellingskeuken en contractcatering Hulpkrachten horeca en verzorging

Verzorgend personeel

Bedrijfshoofden horeca

Chauffeurs

BBL MKF Verpleging en verzorging

Verplegenden en doktersassistenten 
Tabel B3.6 (vervolg)

Belangrijkste beroepsgroepen waarin schoolverlaters werkzaam zijn

BBL MKF Verpleging en verzorging (vervolg)

Ziekenverzorgenden

Therapeuten en verpleegkundigen

BBL MKF Sociaal-pedagogisch werk

Activiteitenbegeleiders en medewerkers arbeidsbemiddeling 36

Verzorgend personeel

Hulpkrachten horeca en verzorging

Verplegenden en doktersassistenten

BBL Specialist Energietechniek

Elektromonteurs

Aannemers en installateurs

19

Programmeurs

Technisch-commercieel employés

Monteurs

Productieplanners

BBL Specialist Verpleging en verzorging

Verzorgend personeel

Docenten exacte, medische en verzorgende vakken (2e en $3 e \mathrm{gr}$ )

Ziekenverzorgenden

Therapeuten en verpleegkundigen

Activiteitenbegeleiders en medewerkers arbeidsbemiddeling

Zie ook toelichting bladzijde 37 
Tabel B3.7

Grootte van de organisatie waarin schoolverlaters werkzaam zijn

\begin{tabular}{|c|c|c|c|c|c|}
\hline Opleidingsrichting & $\begin{array}{r}1 \text { pers } \\
\%\end{array}$ & $\begin{array}{r}2 \mathrm{t} / \mathrm{m} 9 \\
\text { pers } \\
\%\end{array}$ & $\begin{array}{r}10 \mathrm{t} / \mathrm{m} 99 \\
\text { pers } \\
\%\end{array}$ & $\begin{array}{r}100 \mathrm{t} / \mathrm{m} \\
999 \text { pers }\end{array}$ & $\begin{array}{r}\geq 1000 \\
\text { pers } \\
\%\end{array}$ \\
\hline
\end{tabular}

VBO

IVBO Landbouw en natuurlijke omgeving

Landbouw en natuurlijke omgeving

Bouwtechniek

Mechanische techniek

Elektrotechniek

Motorvoertuigentechniek

Consumptieve techniek

Administratie

Verkoop

Verzorging

$\begin{array}{rrrr}31 & 42 & 14 & 12 \\ 28 & 42 & 11 & 19 \\ 27 & 46 & 16 & 12 \\ 13 & 63 & 18 & 6 \\ 27 & 24 & 32 & 17 \\ 14 & 55 & 29 & 0 \\ 17 & 59 & 13 & 11 \\ 21 & 37 & 20 & 17 \\ 16 & 41 & 26 & 16 \\ 26 & 34 & 16 & 24\end{array}$

BOL niveau $1 / 2$

$\mathrm{AB}$ Beveiliging

$A B$ Detailhandel/ambulante handel

BB Bouw

BB Houtbewerking en woninginrichting

BB Bedrijfsadministratie

BB Beveiliging

BB Commercieel

BB Secretarieel

BB Detailhandel/ambulante handel

BB Horeca, instellingskeuken en contractcatering

BB Facilitaire dienstverlening

BB Verpleging en verzorging

BOL niveau $3 / 4$

ZB Plantenteelt

ZB Veehouderij

ZB Bloemschikken

ZB Groene ruimte

ZB Scheepvaart

ZB Bedrijfsadministratief

ZB Secretarieel

ZB Detailhandel/ambulante handel

$Z B$ Verpleging en verzorging

ZB Uiterlijke verzorging

KF Plantenteelt

KF Veehouderij

KF Bloemschikken

KF Groene ruimte

KF Milieutoezicht

MKF Bouw

MKF Houtbewerking en woninginrichting

MKF Grond-, water- en wegenbouw

MKF Beschermings- en afwerkingstechnieken

MKF Reclame, presentatie en communicatie

MKF Werktuigbouwkunde

MKF Motorvoertuigen

MKF Energie- en informatietechniek

MKF Informatietechniek

MKF Graf. techn, communicatie, audiovisueel en

multimedia

MKF Laboratoriumtechniek

MKF Scheepvaart

MKF Transport en logistiek

MKF Bedrijfsadministratief

$\begin{array}{rrrr}4 & 26 & 9 & 62 \\ 35 & 13 & 29 & 24 \\ 0 & 36 & 32 & 32 \\ 26 & 33 & 26 & 0 \\ 9 & 48 & 30 & 13 \\ 0 & 41 & 17 & 42 \\ 19 & 14 & 31 & 36 \\ 7 & 72 & 8 & 13 \\ 9 & 24 & 44 & 22 \\ 21 & 31 & 28 & 20 \\ 15 & 39 & 13 & 33 \\ 10 & 26 & 39 & 25\end{array}$

$\begin{array}{rrrr}30 & 48 & 4 & 11 \\ 46 & 32 & 7 & 14 \\ 39 & 43 & 11 & 6 \\ 25 & 45 & 26 & 4 \\ 22 & 36 & 27 & 12 \\ 9 & 48 & 16 & 28 \\ 4 & 33 & 10 & 52 \\ 40 & 35 & 8 & 17 \\ 1 & 12 & 50 & 38 \\ 45 & 23 & 10 & 14 \\ 46 & 26 & 20 & 4 \\ 38 & 33 & 10 & 15 \\ 35 & 42 & 13 & 10 \\ 46 & 49 & 3 & 0 \\ 6 & 45 & 31 & 17 \\ 16 & 38 & 29 & 17 \\ 27 & 47 & 19 & 5 \\ 3 & 29 & 25 & 43 \\ 27 & 47 & 7 & 19 \\ 26 & 36 & 17 & 21 \\ 8 & 40 & 20 & 31 \\ 18 & 76 & 7 & 0 \\ 12 & 28 & 17 & 44 \\ 9 & 23 & 22 & 45 \\ & & & \\ 37 & 41 & 16 & 5 \\ 0 & 16 & 37 & 47 \\ 12 & 8 & 26 & 55 \\ 6 & 31 & 21 & 42 \\ 15 & 25 & 23 & 34\end{array}$


Tabel B3.7 (vervolg)

Grootte van de organisatie waarin schoolverlaters werkzaam zijn

\begin{tabular}{|c|c|c|c|c|}
\hline Opleidingsrichting & $\begin{array}{r}1 \text { pers } \\
\%\end{array}$ & $\begin{array}{r}2 \mathrm{t} / \mathrm{m} 9 \\
\text { pers } \\
\%\end{array}$ & $\begin{array}{r}10 \mathrm{t} / \mathrm{m} 99 \\
\text { pers } \\
\%\end{array}$ & $\begin{array}{r}100 \mathrm{t} / \mathrm{m} \\
999 \text { pers } \\
\%\end{array}$ \\
\hline
\end{tabular}

BOL niveau 3/4 (vervolg)

MKF Commerciee

MKF Economisch-juridisch

MKF Secretarieel

MKF Detailhandel/ambulante handel

MKF Groothandel/distributie

MKF Horeca, instellingskeuken en contractcatering

MKF Toerisme, recreatie en reizen

MKF Assistenten gezondheidszorg

MKF Facilitaire dienstverlening

MKF Sport en bewegen

MKF Verpleging en verzorging

MKF Maatschappelijke dienstverlening

MKF Sociaal-pedagogisch werk algemeen

MKF Sociaal-juridisch werk

BBL niveau $1 / 2$

AB Beveiliging

$A B$ Horeca, instellingskeuken en contractcatering

BB Plantenteelt

BB Bloemschikken

BB Groene ruimte

BB Bouw

BB Houtbewerking en woninginrichting

BB Constructie-, plaatwerken/pijpenbewerken

BB Machinebankwerken/verspanen

BB Motorvoertuigen

BB Energie- en informatietechniek

BB Installatie-, service- en onderhoudstechniek

BB Graf. techn, communicatie, audiovisueel en

multimedia

BB Wegvervoer

BB Detailhandel/ambulante handel

BB Opslag/magazijn

BB Horeca, instellingskeuken en contractcatering

BB Facilitaire dienstverlening

BB Verpleging en verzorging

BB Uiterlijke verzorging

$\begin{array}{rrrr}13 & 33 & 19 & 35 \\ 7 & 33 & 22 & 38 \\ 10 & 34 & 24 & 31 \\ 19 & 31 & 23 & 26 \\ 9 & 46 & 36 & 9 \\ 4 & 35 & 31 & 29 \\ 14 & 17 & 34 & 31 \\ 30 & 47 & 7 & 13 \\ 5 & 32 & 28 & 35 \\ 13 & 33 & 32 & 17 \\ 2 & 3 & 31 & 64 \\ 0 & 11 & 28 & 61 \\ 6 & 32 & 40 & 21 \\ 0 & 14 & 28 & 58\end{array}$

BBL niveau $3 / 4$

ZB Bloemschikken

ZB Groene ruimte

ZB Bouw

ZB Grond-, water- en wegenbouw

ZB Beschermings- en afwerkingstechnieken

ZB Motorvoertuigen

ZB Beheer, ontwerp en management (instal. techn)

ZB Installatie-, service- en onderhoudstechniek

ZB Procestechniek

ZB Detailhandel/ambulante handel

ZB Horeca, instellingskeuken en contractcatering

ZB Verpleging en verzorging

ZB Uiterlijke verzorging

ZB Sociaal-pedagogisch werk

MKF Detailhandel/ambulante handel

MKF Horeca, instellingskeuken en contractcatering

MKF Verpleging en verzorging

MKF Sociaal-pedagogisch werk

Specialist Energietechniek

Specialist Verpleging en verzorging

$\begin{array}{rrrr}0 & 28 & 35 & 37 \\ 6 & 44 & 38 & 12 \\ 31 & 61 & 8 & 0 \\ 51 & 21 & 11 & 14 \\ 14 & 39 & 26 & 20 \\ 19 & 48 & 23 & 10 \\ 17 & 75 & 8 & 0 \\ 8 & 41 & 27 & 24 \\ 21 & 57 & 20 & 2 \\ 44 & 39 & 5 & 7 \\ 0 & 16 & 34 & 51 \\ 17 & 48 & 17 & 17 \\ 39 & 53 & 0 & \\ 15 & 55 & 24 & 6 \\ 19 & 31 & 18 & 32 \\ 0 & 30 & 20 & 50 \\ 20 & 51 & 9 & 20 \\ 6 & 0 & 35 & 58 \\ 0 & 19 & 47 & 34 \\ 46 & 26 & 9 & 19\end{array}$

Zie ook toelichting bladzijde 39 
Tabel B3.8

Beloning van werkende schoolverlaters

Opleidingsrichting

gemiddeld bruto

gemiddeld bruto

maandloon

uurloon

VBO

IVBO Landbouw en natuurlijke omgeving

Landbouw en natuurlijke omgeving

Bouwtechniek

$614 \quad 4,05$

Mechanische techniek

4,14

Elektrotechniek

$711-4,84$
$578-3,87$

Motorvoertuigentechniek

3,87

Consumptieve techniek

578
712

4,56

Administratie

$668 \quad 4,71$

$739 \quad 4,98$

Verkoop

Verzorging

3,95

$\begin{array}{ll}593 & 3,92 \\ 617 & 4,37\end{array}$

BOL niveau $1 / 2$

$A B$ Beveiliging

$A B$ Detailhandel/ambulante handel

BB Bouw

$\begin{array}{ll}729 & 7,41 \\ 798 & 5,39\end{array}$

BB Houtbewerking en woninginrichting

1.379

5,39
8,46

BB Bedrijfsadministratie

$\begin{array}{ll}1.258 & 8,12 \\ 1.015 & 6,40\end{array}$

BB Beveiliging

BB Commercieel

BB Secretarieel

BB Detailhandel/ambulante handel

BB Horeca, instellingskeuken en contractcatering

1.015

8,12
6,40

$\begin{array}{ll}045 & 8,04\end{array}$

$1.363 \quad 8,79$

$874 \quad 6,10$

$1.085 \quad 7,88$

BB Facilitaire dienstverlening

$\begin{array}{ll}942 & 6,62 \\ .067 & 7,37\end{array}$

$B B$ Verpleging en verzorging

BOL niveau $3 / 4$

ZB Plantenteelt

ZB Veehouderij

ZB Bloemschikken

ZB Groene ruimte

ZB Scheepvaart

$\begin{array}{rr}894 & 6,38 \\ 1.262 & 7,57\end{array}$

ZB Bedriifsadministratief

$\begin{array}{ll}1.788 & 9,07\end{array}$

ZB Secretarieel

$\begin{array}{ll}1.788 & 9,07 \\ 1.212 & 7,77\end{array}$

ZB Detailhandel/ambulante handel

1217

7,40

$Z B$ Verpleging en verzorging

933

5,65

ZB Uiterlijke verzorging

KF Plantenteelt

1.200

8,92

KF Veehouderij

$846 \quad 6,34$

1.520

8,52

KF Bloemschikken

1.141

7,47

KF Groene ruimte

976
1.541

6,60

KF Milieutoezicht

1.615

9,61

MKF Bouw

$1.615-9,85$

MKF Houtbewerking en woninginrichting

9,72

$1.374-8,68$

MKF Grond-, water- en wegenbouw

$\begin{array}{ll}1.655 & 9,74 \\ 1.439 & 8,99\end{array}$

MKF Beschermings- en afwerkingstechnieken

MKF Reclame, presentatie en communicatie

7,49

MKF Werktuigbouwkunde

1.267

$\begin{array}{ll}1.267 & 7,49 \\ 1.577 & 9,38 \\ 1.355 & 7,72\end{array}$

MKF Motorvoertuigen

MKF Energie- en informatietechniek

$\begin{array}{rr}1.355 & 9,72 \\ 1.568 & 9,70 \\ 1.854 & 11,12\end{array}$

MKF Informatietechniek

MKF Graf techn, communicatie, audiovisueel en multimedia

MKF Laboratoriumtechniek

$\begin{array}{lr}1.417 & 8,60 \\ 1.439 & 9,11\end{array}$

$2.115 \quad 10,44$

MKF Scheepvaart

10,21
7,62

MKF Transport en logistiek

1.608

Bedrijfsadministratief

1.203

1.302

7,95

MKF Economisch-juridisch 
Tabel B3. 8 (vervolg)

Beloning van werkende schoolverlaters

\begin{tabular}{lrr}
\hline Opleidingsrichting & $\begin{array}{r}\text { gemiddeld bruto } \\
\text { maandloon }\end{array}$ & $\begin{array}{r}\text { gemiddeld bruto } \\
\text { uurloon }\end{array}$ \\
$€$
\end{tabular}

BOL niveau 3/4 (vervolg)

MKF Secretarieel

MKF Detailhandel/ambulante handel

MKF Groothandel/distributie

MKF Horeca, instellingskeuken en contractcatering

MKF Toerisme, recreatie en reizen

MKF Assistenten gezondheidszorg

MKF Facilitaire dienstverlening

MKF Sport en bewegen

MKF Verpleging en verzorging

MKF Maatschappelijke dienstverlening

MKF Sociaal-pedagogisch werk algemeen

MKF Sociaal-juridisch werk

$\begin{array}{rr}1.353 & 8,13 \\ 1.168 & 7,68 \\ 1.396 & 8,54 \\ 1.467 & 9,39 \\ 1.317 & 7,94 \\ 1.201 & 8,00 \\ 1.375 & 8,31 \\ 1.348 & 9,93 \\ 1.505 & 10,28 \\ 1.194 & 7,97 \\ 1.168 & 9,13 \\ 1.566 & 10,39\end{array}$

$B B L$ niveau $1 / 2$

AB Beveiliging

$A B$ Horeca, instellingskeuken en contractcatering

BB Plantenteelt

BB Bloemschikken

BB Groene ruimte

BB Bouw

BB Houtbewerking en woninginrichting

BB Constructie-, plaatwerken/pijpenbewerken

BB Machinebankwerken/verspanen

BB Motorvoertuigen

BB Energie- en informatietechniek

BB Installatie-, service- en onderhoudstechniek

BB Graf. techn, communicatie, audiovisueel en multimedia

BB Wegvervoer

BB Detailhandel/ambulante handel

$1.392 \quad 9,04$

$1.188 \quad 6,52$

$\begin{array}{ll}1.076 & 6,95\end{array}$

$794 \quad 6,09$

$1.364 \quad 8,22$

$1.599 \quad 10,76$

1.165

$1.317 \quad 7,84$

$1.221 \quad 7,17$

$1.221 \quad 7,22$

$1.409 \quad 8,48$

$1.462 \quad 9,01$

$1.302 \quad 8,01$

$1.464 \quad 8,16$

$913 \quad 6,44$

1.578

BB Horeca, instellingskeuken en contractcatering $\quad 1.048 \quad 6,87$

$\begin{array}{lll}\text { BB Facilitaire dienstverlening } & 1.022 & 9,37\end{array}$

BB Verpleging en verzorging $\quad 1.179 \quad 8,69$

$\begin{array}{lll}\text { BB Uiterlijke verzorging } & 942 & 6,18\end{array}$

BBL niveau $3 / 4$

ZB Bloemschikken $\quad 1.003 \quad 6,47$

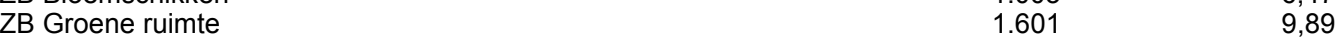

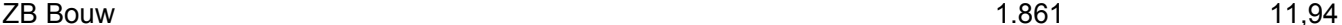

ZB Grond-, water- en wegenbouw $\quad 1.749 \quad 10,20$

ZB Beschermings- en afwerkingstechnieken $\quad 2.095 \quad 12,77$

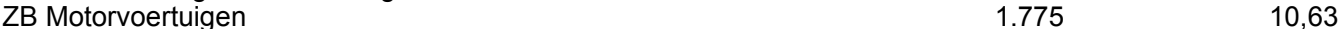

ZB Beheer, ontwerp en management (instal. techn) $\quad 2.088 \quad 12,59$

ZB Installatie-, service- en onderhoudstechniek $\quad 1.587 \quad 9,48$

$2.313 \quad 15,03$

ZB Detailhandel/ambulante handel $\quad 1.169 \quad 7,34$

ZB Horeca, instellingskeuken en contractcatering $\quad 1.507 \quad 9,02$

ZB Verpleging en verzorging $\quad 1.389 \quad 11,57$

ZB Uiterlijke verzorging $\quad 915 \quad 6,23$

ZB Sociaal-pedagogisch werk $\quad 1.089 \quad 9,35$

$\begin{array}{lll}\text { MKF Detailhandel/ambulante handel } & 1.461 & 9,19\end{array}$

MKF Horeca, instellingskeuken en contractcatering $\quad 1.350 \quad 8,53$

$\begin{array}{lrr}\text { MKF Verpleging en verzorging } & 1.770 & 12,86\end{array}$

MKF Sociaal-pedagogisch werk $\quad 1.611 \quad 12,59$

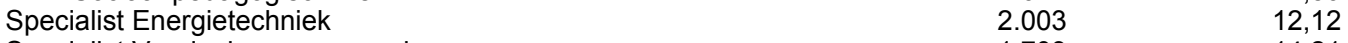

Specialist Verpleging en verzorging $\quad 1.703 \quad 14,21$

Zie ook toelichting bladzijde 41 
Tabel B3.9

Vereist opleidingsniveau voor de huidige functie volgens de schoolverlaters en de werkgever

\begin{tabular}{lrrr}
\hline & & & \\
Opleidingsrichting & lager & zelfde & hoger \\
& $\%$ & $\%$ & \\
& & & \\
& & & \\
VBO & 39 & 45 & 17 \\
IVBO Landbouw en natuurlijke omgeving & 23 & 57 & 20 \\
Landbouw en natuurlijke omgeving & 11 & 45 & 44 \\
Bouwtechniek & 29 & 40 & 31 \\
Mechanische techniek & 16 & 42 & 41 \\
Elektrotechniek & 27 & 44 & 29 \\
Motorvoertuigentechniek & 14 & 36 & 49 \\
Consumptieve techniek & 27 & 51 & 21 \\
Administratie & 35 & 64 & 1 \\
Verkoop & 32 & 56 & 12 \\
Verzorging & & & \\
BOL niveau 1/2 & & & \\
AB Beveiliging & 83 & 10 & 7 \\
AB Detailhandel/ambulante handel & 83 & 17 & \\
BB Bouw & 29 & 12 & 59 \\
BB Houtbewerking en woninginrichting & 39 & 33 & 28 \\
BB Bedrijfsadministratie & 45 & 26 & 29 \\
BB Beveiliging & 91 & 9 & \\
BB Commercieel & 58 & 2 & 40 \\
BB Secretarieel & 62 & 14 & 24 \\
BB Detailhandel/ambulante handel & 65 & 15 & 20 \\
BB Horeca, instellingskeuken en contractcatering & 54 & 19 & 26 \\
BB Facilitaire dienstverlening & 79 & 4 & 17 \\
BB Verpleging en verzorging & 38 & 52 & 11
\end{tabular}

BOL niveau $3 / 4$

ZB Plantenteelt

ZB Veehouderij

ZB Bloemschikken

ZB Groene ruimte

ZB Scheepvaart

ZB Bedrijfsadministratief

ZB Secretarieel

ZB Detailhandel/ambulante handel

ZB Verpleging en verzorging

ZB Uiterlijke verzorging

KF Plantenteelt

KF Veehouderij

KF Bloemschikken

KF Groene ruimte

KF Milieutoezicht

MKF Bouw

MKF Houtbewerking en woninginrichting

MKF Grond-, water- en wegenbouw

MKF Beschermings- en afwerkingstechnieken

MKF Reclame, presentatie en communicatie

MKF Werktuigbouwkunde

MKF Motorvoertuigen

MKF Energie- en informatietechniek

MKF Informatietechniek

MKF Graf. techn, communicatie, audiovisueel en multimedia

MKF Laboratoriumtechniek

MKF Scheepvaart

MKF Transport en logistiek

MKF Bedrijfsadministratief

MKF Commercieel

MKF Economisch-juridisch

$\begin{array}{rrr}56 & 44 & \\ 61 & 39 & \\ 51 & 49 & \\ 45 & 55 & \\ 42 & 58 & \\ 16 & 77 & 6 \\ 47 & 52 & 1 \\ 48 & 52 & \\ 17 & 82 & 1 \\ 56 & 44 & \\ 67 & 33 & \\ 58 & 42 & \\ 44 & 54 & 2 \\ 9 & 91 & \\ 11 & 79 & 10 \\ 21 & 78 & 1 \\ 31 & 66 & 3 \\ 3 & 97 & \\ 64 & 36 & \\ 44 & 51 & 5 \\ 25 & 75 & 1 \\ 55 & 45 & \\ 18 & 76 & 5 \\ 14 & 66 & 20 \\ 28 & 72 & \\ 17 & 75 & 8 \\ 25 & 67 & 8 \\ 54 & 46 & \\ 21 & 71 & 8 \\ 23 & 70 & 8 \\ 27 & 55 & 19\end{array}$


Tabel B3.9 (vervolg)

Vereist opleidingsniveau voor de huidige functie volgens de schoolverlaters en de werkgever

\begin{tabular}{lrr}
\hline Opleidingsrichting & $\begin{array}{l}\text { lager } \\
\%\end{array}$ & $\begin{array}{r}\text { zelfde } \\
\%\end{array}$ \\
& hoger \\
\hline
\end{tabular}

\footnotetext{
BOL niveau 3/4 (vervolg)

MKF Secretarieel

MKF Detailhandel/ambulante handel

MKF Groothandel/distributie

MKF Horeca, instellingskeuken en contractcatering

MKF Toerisme, recreatie en reizen

MKF Assistenten gezondheidszorg

MKF Facilitaire dienstverlening

MKF Sport en bewegen

MKF Verpleging en verzorging

MKF Maatschappelijke dienstverlening

MKF Sociaal-pedagogisch werk algemeen

MKF Sociaal-juridisch werk
}

$\begin{array}{rrr}28 & 70 & 2 \\ 44 & 56 & \\ 36 & 50 & 14 \\ 23 & 74 & 2 \\ 38 & 63 & \\ 25 & 73 & 1 \\ 23 & 72 & 5 \\ 36 & 58 & 6 \\ 7 & 91 & 2 \\ 14 & 82 & 4 \\ 25 & 72 & 3 \\ 20 & 65 & 15\end{array}$

\section{$B B L$ niveau $1 / 2$}

$A B$ Beveiliging

$A B$ Horeca, instellingskeuken en contractcatering

BB Plantenteelt

BB Bloemschikken

BB Groene ruimte

BB Bouw

BB Houtbewerking en woninginrichting

BB Constructie-, plaatwerken/pijpenbewerken

BB Machinebankwerken/verspanen

BB Motorvoertuigen

BB Energie- en informatietechniek

BB Installatie-, service- en onderhoudstechniek

BB Graf. techn, communicatie, audiovisueel en multimedia

BB Wegvervoer

BB Detailhandel/ambulante handel

BB Opslag/magazijn

BB Horeca, instellingskeuken en contractcatering

BB Facilitaire dienstverlening

BB Verpleging en verzorging

BB Uiterlijke verzorging

BBL niveau $3 / 4$

ZB Bloemschikken

ZB Groene ruimte

ZB Bouw

ZB Grond-, water- en wegenbouw

ZB Beschermings- en afwerkingstechnieken

ZB Motorvoertuigen

ZB Beheer, ontwerp en management (instal. techn)

ZB Installatie-, service- en onderhoudstechniek

ZB Procestechniek

ZB Detailhandel/ambulante handel

ZB Horeca, instellingskeuken en contractcatering

ZB Verpleging en verzorging

ZB Uiterlijke verzorging

ZB Sociaal-pedagogisch werk

MKF Detailhandel/ambulante handel

MKF Horeca, instellingskeuken en contractcatering

MKF Verpleging en verzorging

MKF Sociaal-pedagogisch werk

Specialist Energietechniek

Specialist Verpleging en verzorging 
Tabel B3.10

Vereiste opleidingsrichting voor de huidige functie volgens de werkgever

\begin{tabular}{lrrr}
\hline Opleidingsrichting & $\begin{array}{r}\text { eigen/ } \\
\text { verwante } \\
\text { richting } \\
\%\end{array}$ & $\begin{array}{r}\text { andere } \\
\text { richting }\end{array}$ & $\begin{array}{r}\text { geen } \\
\text { richting }\end{array}$ \\
$\%$
\end{tabular}

VBO

IVBO Landbouw en natuurlijke omgeving

$\begin{array}{rrr}38 & 15 & 47 \\ 46 & 8 & 46 \\ 81 & 4 & 15 \\ 52 & 1 & 47 \\ 52 & 9 & 39 \\ 66 & 13 & 22 \\ 81 & 4 & 15 \\ 36 & 5 & 59 \\ 27 & 8 & 65 \\ 27 & 1 & 73\end{array}$

Landbouw en natuurlijke omgeving

Bouwtechniek

Mechanische techniek

Elektrotechniek

Motorvoertuigentechniek

Consumptieve techniek

Administratie

Verkoop

Verzorging

$\begin{array}{rrr}33 & 14 & 53 \\ 33 & & 67 \\ 70 & 26 & 5 \\ 35 & 15 & 50 \\ 63 & 2 & 36 \\ 57 & & 43 \\ 31 & 45 & 24 \\ 56 & & 44 \\ 39 & 2 & 59 \\ 49 & 3 & 48 \\ 51 & 9 & 39 \\ 82 & & \end{array}$

BOL niveau 1/2

$\mathrm{AB}$ Beveiliging

AB Detailhandel/ambulante handel

BB Bouw

BB Houtbewerking en woninginrichting

BB Bedrijfsadministratie

BB Beveiliging

BB Commerciee

BB Secretarieel

BB Detailhandel/ambulante handel

BB Horeca, instellingskeuken en contractcatering

BB Facilitaire dienstverlening

BB Verpleging en verzorging

BOL niveau $3 / 4$

ZB Plantenteelt

ZB Veehouderij

ZB Bloemschikken

ZB Groene ruimte

ZB Scheepvaart

ZB Bedrijfsadministratief

ZB Secretarieel

ZB Detailhandel/ambulante handel

ZB Verpleging en verzorging

ZB Uiterlijke verzorging

KF Plantenteelt

KF Veehouderij

KF Bloemschikken

KF Groene ruimte

KF Milieutoezicht

MKF Bouw

MKF Houtbewerking en woninginrichting

MKF Grond-, water- en wegenbouw

MKF Beschermings- en afwerkingstechnieken

MKF Reclame, presentatie en communicatie

MKF Werktuigbouwkunde

MKF Motorvoertuigen

MKF Energie- en informatietechniek

MKF Informatietechniek

MKF Graf. techn, communicatie, audiovisueel en multimedia

MKF Laboratoriumtechniek

MKF Scheepvaart

MKF Transport en logistiek

MKF Bedrijfsadministratief

$\begin{array}{rr}3 & 46 \\ 10 & 29 \\ 7 & 25 \\ 2 & 23 \\ & 9 \\ & 17 \\ 3 & 9 \\ 19 & 18 \\ 4 & 9 \\ 9 & 28 \\ 1 & 32 \\ 8 & 45 \\ 10 & 37 \\ 8 & 3 \\ 6 & 2 \\ 3 & 18 \\ 4 & 29 \\ 3 & 6 \\ & 46 \\ 2 & 31 \\ 6 & 8 \\ 14 & 24 \\ 20 & 12 \\ 22 & 18 \\ 7 & 22 \\ 2 & 15 \\ & 11 \\ 19 & 19 \\ 7 & 13\end{array}$


Tabel B3.10 (vervolg)

Vereiste opleidingsrichting voor de huidige functie volgens de werkgever

\begin{tabular}{lrrr}
\hline Opleidingsrichting & $\begin{array}{r}\text { eigen/ } \\
\text { verwante } \\
\text { richting } \\
\%\end{array}$ & $\begin{array}{r}\text { andere } \\
\text { richting }\end{array}$ & $\begin{array}{r}\text { geen } \\
\text { richting }\end{array}$ \\
$\%$ & & $\%$ \\
\hline
\end{tabular}

BOL niveau 3/4 (vervolg)

MKF Commercieel

$\begin{array}{lll}58 & 8 & 34\end{array}$

MKF Economisch-juridisch

MKF Secretarieel

MKF Detailhandel/ambulante handel

MKF Groothandel/distributie

MKF Horeca, instellingskeuken en contractcatering

MKF Toerisme, recreatie en reizen

MKF Assistenten gezondheidszorg

MKF Facilitaire dienstverlening

MKF Sport en bewegen

MKF Verpleging en verzorging

MKF Maatschappelijke dienstverlening

MKF Sociaal-pedagogisch werk algemeen

MKF Sociaal-juridisch werk

$\begin{array}{lrl}52 & 29 & 19 \\ 72 & 6 & 22 \\ 49 & 10 & 41 \\ 58 & 15 & 26 \\ 64 & 9 & 27 \\ 60 & 26 & 14 \\ 85 & 2 & 13 \\ 44 & 18 & 37 \\ 76 & 3 & 22 \\ 88 & & 12 \\ 41 & 34 & 26 \\ 78 & 6 & 16 \\ 68 & 6 & 26\end{array}$

BBL niveau $1 / 2$

AB Beveiliging

$A B$ Horeca, instellingskeuken en contractcatering

BB Plantenteelt

BB Bloemschikken

BB Groene ruimte

BB Bouw

BB Houtbewerking en woninginrichting

BB Constructie-, plaatwerken/pijpenbewerken

BB Machinebankwerken/verspanen

BB Motorvoertuigen

BB Energie- en informatietechniek

BB Installatie-, service- en onderhoudstechniek

BB Graf. techn, communicatie, audiovisueel en multimedia

BB Wegvervoer

BB Detailhandel/ambulante handel

BB Opslag/magazijn

BB Horeca, instellingskeuken en contractcatering

BB Facilitaire dienstverlening

BB Verpleging en verzorging

BB Uiterlijke verzorging

$\begin{array}{rrr}39 & 39 & 22 \\ 32 & 21 & 47 \\ 32 & & 68 \\ 43 & 3 & 55 \\ 50 & 2 & 48 \\ 70 & 3 & 26 \\ 78 & & 22 \\ 58 & 3 & 39 \\ 87 & 7 & 6 \\ 75 & 4 & 21 \\ 77 & 11 & 11 \\ 78 & & 22 \\ 86 & 2 & 12 \\ 78 & 2 & 20 \\ 32 & 4 & 64 \\ 35 & 10 & 55 \\ 78 & 8 & 14 \\ 57 & 17 & 26 \\ 67 & 12 & 21 \\ 77 & 4 & 19\end{array}$

BBL niveau $3 / 4$

ZB Bloemschikken

ZB Groene ruimte

ZB Bouw

ZB Grond-, water- en wegenbouw

ZB Beschermings- en afwerkingstechnieken

ZB Motorvoertuigen

ZB Beheer, ontwerp en management (instal. techn)

ZB Installatie-, service- en onderhoudstechniek

ZB Procestechniek

ZB Detailhandel/ambulante handel

ZB Horeca, instellingskeuken en contractcatering

ZB Verpleging en verzorging

ZB Uiterlijke verzorging

ZB Sociaal-pedagogisch werk

MKF Detailhandel/ambulante handel

MKF Horeca, instellingskeuken en contractcatering

MKF Verpleging en verzorging

MKF Sociaal-pedagogisch werk

$\begin{array}{rrr}73 & 4 & 23 \\ 63 & 3 & 34 \\ 72 & & 28 \\ 63 & 7 & 30 \\ 66 & & 34 \\ 73 & 7 & 19 \\ 79 & & 21 \\ 78 & 14 & 8 \\ 79 & 15 & 6 \\ 35 & 9 & 56 \\ 76 & 4 & 20 \\ 83 & 5 & 12 \\ 86 & 7 & 7 \\ 82 & 8 & 10 \\ 50 & 11 & 40 \\ 57 & 1 & 41 \\ 82 & 11 & 7 \\ 89 & 4 & 7\end{array}$


Tabel B3.10 (vervolg)

Vereiste opleidingsrichting voor de huidige functie volgens de werkgever

\begin{tabular}{lrrr}
\hline Opleidingsrichting & $\begin{array}{r}\text { eigen/ } \\
\text { verwante } \\
\text { richting } \\
\%\end{array}$ & $\begin{array}{r}\text { andere } \\
\text { richting }\end{array}$ & $\begin{array}{r}\text { geen } \\
\text { richting }\end{array}$ \\
$\%$ & & $\%$
\end{tabular}

BBL niveau 3/4 (vervolg)

Specialist Energietechniek

Specialist Verpleging en verzorging

Zie ook toelichting bladzijde 43 
Tabel B3.11

Gewenste en feitelijke wekelijkse arbeidsduur van werkende schoolverlaters

\begin{tabular}{|c|c|c|}
\hline Opleidingsrichting & $\begin{array}{r}\text { gewenste } \\
\text { wekelijkse } \\
\text { arbeidsduur } \\
\text { uren }\end{array}$ & $\begin{array}{r}\text { feitelijke } \\
\text { wekelijkse } \\
\text { arbeidsduur } \\
\text { uren }\end{array}$ \\
\hline \multicolumn{3}{|l|}{ VBO } \\
\hline IVBO Landbouw en natuurlijke omgeving & 35,8 & 33,1 \\
\hline Landbouw en natuurlijke omgeving & 36,4 & 33,7 \\
\hline Bouwtechniek & 35,4 & 34,7 \\
\hline Mechanische techniek & 38,7 & 34,8 \\
\hline Elektrotechniek & 39,2 & 36,5 \\
\hline Motorvoertuigentechniek & 40,5 & 35,3 \\
\hline Consumptieve techniek & 35,0 & 31,4 \\
\hline Administratie & 31,0 & 30,4 \\
\hline Verkoop & 34,8 & 31,4 \\
\hline Verzorging & 34,0 & 30,6 \\
\hline \multicolumn{3}{|l|}{ BOL niveau $1 / 2$} \\
\hline AB Beveiliging & 38,4 & 37,6 \\
\hline AB Detailhandel/ambulante handel & 32,9 & 33,5 \\
\hline BB Bouw & 39,2 & 38,4 \\
\hline BB Houtbewerking en woninginrichting & 36,7 & 36,9 \\
\hline BB Bedrijfsadministratie & 37,4 & 37,4 \\
\hline BB Beveiliging & 37,7 & 33,9 \\
\hline BB Commercieel & 36,8 & 36,5 \\
\hline BB Secretarieel & 36,1 & 34,8 \\
\hline BB Detailhandel/ambulante handel & 35,6 & 34,5 \\
\hline BB Horeca, instellingskeuken en contractcatering & 36,3 & 35,6 \\
\hline BB Facilitaire dienstverlening & 39,5 & 30,6 \\
\hline BB Verpleging en verzorging & 33,4 & 30,8 \\
\hline \multicolumn{3}{|l|}{ BOL niveau $3 / 4$} \\
\hline ZB Plantenteelt & 44,8 & 40,2 \\
\hline ZB Veehouderij & 40,2 & 39,0 \\
\hline ZB Bloemschikken & 37,0 & 35,4 \\
\hline ZB Groene ruimte & 38,6 & 39,5 \\
\hline ZB Scheepvaart & 50,3 & 44,0 \\
\hline ZB Bedrijfsadministratief & 37,1 & 37,9 \\
\hline ZB Secretarieel & 37,7 & 37,7 \\
\hline ZB Detailhandel/ambulante handel & 35,9 & 38,2 \\
\hline ZB Verpleging en verzorging & 32,9 & 32,1 \\
\hline ZB Uiterlijke verzorging & 34,7 & 32,2 \\
\hline KF Plantenteelt & 44,6 & 43,1 \\
\hline KF Veehouderij & 40,5 & 38,9 \\
\hline KF Bloemschikken & 37,0 & 37,1 \\
\hline KF Groene ruimte & 38,1 & 38,0 \\
\hline KF Milieutoezicht & 36,7 & 37,9 \\
\hline MKF Bouw & 39,2 & 39,0 \\
\hline MKF Houtbewerking en woninginrichting & 36,6 & 37,5 \\
\hline MKF Grond-, water- en wegenbouw & 40,1 & 39,5 \\
\hline MKF Beschermings- en afwerkingstechnieken & 39,5 & 36,9 \\
\hline MKF Reclame, presentatie en communicatie & 37,7 & 39,5 \\
\hline MKF Werktuigbouwkunde & 39,8 & 40,0 \\
\hline MKF Motorvoertuigen & 40,2 & 39,9 \\
\hline MKF Energie- en informatietechniek & 38,9 & 38,7 \\
\hline MKF Informatietechniek & 38,3 & 38,9 \\
\hline MKF Graf. techn, communicatie, audiovisueel en multimedia & 37,9 & 38,5 \\
\hline MKF Laboratoriumtechniek & 37,3 & 37,0 \\
\hline MKF Scheepvaart & 55,4 & 44,7 \\
\hline MKF Transport en logistiek & 39,4 & 40,3 \\
\hline MKF Bedrijfsadministratief & 37,6 & 37,4 \\
\hline
\end{tabular}


Tabel B3.11 (vervolg)

Gewenste en feitelijke wekelijkse arbeidsduur van werkende schoolverlaters

\begin{tabular}{|c|c|c|}
\hline Opleidingsrichting & $\begin{array}{r}\text { gewenste } \\
\text { wekelijkse } \\
\text { arbeidsduur } \\
\text { uren }\end{array}$ & $\begin{array}{r}\text { feitelijke } \\
\text { wekelijkse } \\
\text { arbeidsduur } \\
\text { uren }\end{array}$ \\
\hline
\end{tabular}

BOL niveau 3/4 (vervolg)

MKF Commerciee

$36,3 \quad 37,7$

MKF Economisch-juridisch

$35,4 \quad 35,5$

MKF Secretarieel

MKF Detailhandel/ambulante handel

$\begin{array}{ll}35,4 & 35,5 \\ 37,2 & 38,5\end{array}$

MKF Groothandel/distributie

MKF Horeca, instellingskeuken en contractcatering

MKF Toerisme, recreatie en reizen

MKF Assistenten gezondheidszorg

MKF Facilitaire dienstverlening

MKF Sport en bewegen

MKF Verpleging en verzorging

MKF Maatschappelijke dienstverlening

MKF Sociaal-pedagogisch werk algemeen

BBL niveau 1/2

$A B$ Beveiliging

AB Horeca, instellingskeuken en contractcatering

BB Plantenteelt

BB Bloemschikken

BB Groene ruimte

BB Bouw

BB Houtbewerking en woninginrichting

BB Constructie-, plaatwerken/pijpenbewerken

BB Machinebankwerken/verspanen

BB Motorvoertuigen

BB Energie- en informatietechniek

BB Installatie-, service- en onderhoudstechniek

BB Graf. techn, communicatie, audiovisueel en multimedia

BB Wegvervoer

BB Detailhandel/ambulante handel

37,6

BB Opslag/magazijn

BB Horeca, instellingskeuken en contractcatering

BB Facilitaire dienstverlening

BB Verpleging en verzorging

BBL niveau 3/4

ZB Bloemschikken

ZB Groene ruimte

ZB Grond-, water- en wegenbouw

ZB Beschermings- en afwerkingstechnieken

ZB Beheer, ontwerp en management (instal. techn)

ZB Sociaal-pedagogisch werk 
Tabel B3.11 (vervolg)

Gewenste en feitelijke wekelijkse arbeidsduur van werkende schoolverlaters

Opleidingsrichting

gewenste

wekelijkse

arbeidsduur

itelijke

wekelijkse

uren

arbeidsduur

uren

BBL niveau 3/4 (vervolg)

Specialist Energietechniek

Specialist Verpleging en verzorging

Zie ook toelichting bladzijde 45 
Tabel B3.12

Oordeel van de werkende schoolverlaters over de aansluiting tussen de afgesloten opleiding en de huidige functie

\begin{tabular}{lrrrr}
\hline Opleidingsrichting & goed & $\begin{array}{r}\text { vol- } \\
\text { doende }\end{array}$ & matig & slecht \\
& $\%$ & $\%$ & $\%$ & $\%$ \\
\hline
\end{tabular}

\section{BOL niveau $1 / 2$}

$\mathrm{AB}$ Beveiliging

AB Detailhandel/ambulante handel

BB Bouw

BB Houtbewerking en woninginrichting

BB Bedrijfsadministratie

BB Beveiliging

BB Commercieel

BB Secretarieel

BB Detailhandel/ambulante handel

BB Horeca, instellingskeuken en contractcatering

BB Facilitaire dienstverlening

$B B$ Verpleging en verzorging

$\begin{array}{rrrr}37 & 31 & 22 & 10 \\ 51 & 20 & 6 & 24 \\ 32 & 39 & 5 & 25 \\ 47 & 34 & 15 & 4 \\ 30 & 44 & 13 & 13 \\ 66 & 13 & 13 & 8 \\ 29 & 48 & 19 & 5 \\ 25 & 63 & 7 & 5 \\ 41 & 37 & 5 & 16 \\ 35 & 48 & 11 & 5 \\ 39 & 47 & & 15 \\ 61 & 24 & 8 & 7\end{array}$

BOL niveau $3 / 4$

ZB Plantenteelt

ZB Veehouderi]

ZB Bloemschikken

ZB Groene ruimte

ZB Scheepvaart

ZB Bedrijfsadministratief

ZB Secretarieel

ZB Detailhandel/ambulante handel

ZB Verpleging en verzorging

ZB Uiterlijke verzorging

KF Plantenteelt

KF Veehouderij

KF Bloemschikken

KF Groene ruimte

KF Milieutoezicht

MKF Bouw

MKF Houtbewerking en woninginrichting

MKF Grond-, water- en wegenbouw

MKF Beschermings- en afwerkingstechnieken

MKF Reclame, presentatie en communicatie

MKF Werktuigbouwkunde

MKF Motorvoertuigen

MKF Energie- en informatietechniek

MKF Informatietechniek

MKF Graf. techn, communicatie, audiovisueel en multimedia

MKF Laboratoriumtechniek

MKF Scheepvaart

MKF Transport en logistiek

MKF Bedrijfsadministratief

MKF Commerciee

MKF Economisch-juridisch

MKF Secretarieel

MKF Detailhandel/ambulante handel

MKF Groothandel/distributie

MKF Horeca, instellingskeuken en contractcatering

MKF Toerisme, recreatie en reizen

MKF Assistenten gezondheidszorg

MKF Facilitaire dienstverlening

MKF Sport en bewegen

MKF Verpleging en verzorging

MKF Maatschappelijke dienstverlening

$\begin{array}{rrrr}50 & 43 & 7 & \\ 35 & 37 & 20 & 8 \\ 62 & 27 & 7 & 4 \\ 32 & 60 & 8 & \\ 67 & 30 & 3 & \\ 53 & 29 & 12 & 5 \\ 55 & 42 & 3 & \\ 47 & 40 & 13 & \\ 55 & 31 & 9 & 5 \\ 65 & 18 & 6 & 10 \\ 48 & 35 & 12 & 5 \\ 40 & 41 & 15 & 5 \\ 50 & 33 & 8 & 8 \\ 61 & 33 & 5 & 1 \\ 39 & 41 & 20 & \\ 35 & 49 & 15 & 1 \\ 35 & 47 & 11 & 7 \\ 19 & 71 & 10 & \\ 34 & 20 & 33 & 13 \\ 42 & 36 & 17 & 5 \\ 31 & 50 & 17 & 2 \\ 25 & 64 & 11 & \\ 36 & 47 & 9 & 8 \\ 40 & 38 & 18 & 4 \\ 46 & 31 & 14 & 8 \\ 47 & 31 & 12 & 9 \\ 42 & 36 & 11 & 10 \\ 22 & 65 & 12 & \\ 32 & 55 & 9 & 5 \\ 42 & 44 & 15 & \\ 15 & 45 & 40 & \\ 49 & 41 & 6 & 5 \\ 39 & 41 & 13 & 7 \\ 19 & 59 & 15 & 7 \\ 42 & 42 & 10 & 6 \\ 23 & 54 & 23 & \\ 67 & 28 & 4 & 2 \\ 22 & 51 & 20 & 8 \\ 65 & 29 & 1 & 4 \\ 47 & 41 & 8 & 3 \\ 20 & 45 & 31 & 4 \\ & & & \end{array}$


Tabel B3.12 (vervolg)

Oordeel van de werkende schoolverlaters over de aansluiting tussen de afgesloten opleiding en de huidige functie

\begin{tabular}{lrrrr}
\hline Opleidingsrichting & goed & $\begin{array}{r}\text { vol- } \\
\text { doende }\end{array}$ & matig & slecht \\
& $\%$ & $\%$ & $\%$ & $\%$ \\
\hline
\end{tabular}

BOL niveau 3/4 (vervolg)

MKF Sociaal-pedagogisch werk algemeen

MKF Sociaal-juridisch werk

$\begin{array}{llll}47 & 35 & 11 & 6 \\ 41 & 26 & 25 & 7\end{array}$

$B B L$ niveau $1 / 2$

$A B$ Beveiliging

$A B$ Horeca, instellingskeuken en contractcatering

BB Plantenteelt

BB Bloemschikken

BB Groene ruimte

BB Bouw

BB Houtbewerking en woninginrichting

BB Constructie-, plaatwerken/pijpenbewerken

BB Machinebankwerken/verspanen

BB Motorvoertuigen

BB Energie- en informatietechniek

BB Installatie-, service- en onderhoudstechniek

BB Graf. techn, communicatie, audiovisueel en multimedia

BB Wegvervoer

BB Detailhandel/ambulante handel

BB Opslag/magazijn

BB Horeca, instellingskeuken en contractcatering

BB Facilitaire dienstverlening

$B B$ Verpleging en verzorging

BB Uiterlijke verzorging

41

$\begin{array}{rrrr}77 & 23 & 0 & \\ 46 & 40 & 5 & 9 \\ 34 & 26 & 28 & 12 \\ 47 & 26 & 13 & 13 \\ 61 & 27 & 6 & 6 \\ 61 & 30 & 3 & 5 \\ 52 & 35 & 8 & 4 \\ 68 & 16 & 8 & 8 \\ 64 & 24 & 5 & 6 \\ 43 & 40 & 8 & 9 \\ 40 & 43 & 17 & \\ 61 & 17 & 9 & 13 \\ 66 & 26 & 9 & \\ 77 & 19 & 3 & 1 \\ 50 & 37 & 5 & 8 \\ 52 & 38 & 5 & 5 \\ 72 & 18 & 10 & \\ 60 & 25 & 6 & 9 \\ 62 & 24 & 11 & 3 \\ 83 & 17 & 0 & \end{array}$

BBL niveau $3 / 4$

ZB Bloemschikken

ZB Groene ruimte

ZB Bouw

ZB Grond-, water- en wegenbouw

ZB Beschermings- en afwerkingstechnieken

ZB Motorvoertuigen

ZB Beheer, ontwerp en management (instal. techn)

ZB Installatie-, service- en onderhoudstechniek

ZB Procestechniek

ZB Detailhandel/ambulante handel

ZB Horeca, instellingskeuken en contractcatering

ZB Verpleging en verzorging

ZB Uiterlijke verzorging

ZB Sociaal-pedagogisch werk

MKF Detailhandel/ambulante handel

MKF Horeca, instellingskeuken en contractcatering

MKF Verpleging en verzorging

MKF Sociaal-pedagogisch werk

Specialist Energietechniek

Specialist Verpleging en verzorging

6

3

1

5

3

Zie ook toelichting bladzijde 46 
Tabel B3.13

Percentage werkende schoolverlaters dat op zoek is naar een andere baan

Opleidingsrichting

VBO

IVBO Landbouw en natuurlijke omgeving $\quad 14$

Landbouw en natuurlijke omgeving $\quad 20$

$\begin{array}{lr}\text { Bouwtechniek } & 0\end{array}$

$\begin{array}{ll}\text { Mechanische techniek } & 29\end{array}$

$\begin{array}{ll}\text { Elektrotechniek } & 11\end{array}$

$\begin{array}{lr}\text { Motorvoertuigentechniek } & 5\end{array}$

Consumptieve techniek

$\begin{array}{ll}\text { Administratie } & 34\end{array}$

Verkoop $\quad 33$

Verzorging 26

BOL niveau $1 / 2$

AB Beveiliging $\quad 30$

AB Detailhandel/ambulante handel $\quad 32$

BB Bouw $\quad 9$

BB Houtbewerking en woninginrichting $\quad 30$

BB Bedrijfsadministratie $\quad 27$

BB Beveiliging $\quad 50$

BB Commercieel $\quad 41$

BB Secretarieel $\quad 29$

$\begin{array}{ll}\text { BB Detailhandel/ambulante handel } & 29\end{array}$

BB Horeca, instellingskeuken en contractcatering $\quad 14$

BB Facilitaire dienstverlening $\quad 5$

BB Verpleging en verzorging $\quad 11$

BOL niveau $3 / 4$

ZB Plantenteelt

ZB Veehouderij 18

ZB Bloemschikken $\quad 31$

ZB Groene ruimte $\quad 10$

ZB Scheepvaart $\quad 3$

ZB Bedrijfsadministratief $\quad 6$

$\begin{array}{ll}\text { ZB Secretarieel } & 7\end{array}$

ZB Detailhandel/ambulante handel $\quad 22$

ZB Verpleging en verzorging $r$

ZB Uiterlijke verzorging $\quad 23$

KF Plantenteelt $\quad 15$

$\begin{array}{lr}\mathrm{KF} \text { Veehouderij } & 20\end{array}$

$\begin{array}{ll}\mathrm{KF} \text { Bloemschikken } & 27\end{array}$

KF Groene ruimte $\quad 6$

$\begin{array}{ll}\text { KF Milieutoezicht } & 42\end{array}$

MKF Bouw $\quad 21$

MKF Houtbewerking en woninginrichting $\quad 22$

MKF Grond-, water- en wegenbouw $\quad 16$

MKF Beschermings- en afwerkingstechnieken $\quad 14$

MKF Reclame, presentatie en communicatie $\quad 22$

$\begin{array}{ll}\text { MKF Werktuigbouwkunde } & 21\end{array}$

MKF Motorvoertuigen $\quad 45$

MKF Energie- en informatietechniek $\quad 27$

MKF Informatietechniek $\quad 15$

MKF Graf. techn, communicatie, audiovisueel en multimedia

MKF Laboratoriumtechniek $\quad 14$

MKF Scheepvaart 11

MKF Transport en logistiek $\quad 16$

MKF Bedrijfsadministratief $r$

MKF Commercieel $\quad 14$

MKF Economisch-juridisch $\quad 25$

MKF Secretarieel $\quad 23$ 
Tabel B3.13 (vervolg)

Percentage werkende schoolverlaters dat op zoek is naar een andere baan

Opleidingsrichting

BOL niveau 3/4 (vervolg)

MKF Detailhandel/ambulante handel $\quad 29$

MKF Groothandel/distributie $\quad 35$

MKF Horeca, instellingskeuken en contractcatering $\quad 32$

MKF Toerisme, recreatie en reizen $\quad 34$

MKF Assistenten gezondheidszorg $\quad 15$

MKF Facilitaire dienstverlening $\quad 35$

MKF Sport en bewegen $\quad 24$

MKF Verpleging en verzorging $\quad 23$

MKF Maatschappelijke dienstverlening $\quad 38$

MKF Sociaal-pedagogisch werk algemeen $\quad 24$

$\begin{array}{lr}\text { MKF Sociaal-juridisch werk } & 6\end{array}$

BBL niveau $1 / 2$

$A B$ Beveiliging

AB Horeca, instellingskeuken en contractcatering 26

$\begin{array}{lr}\text { BB Plantenteelt } & 5\end{array}$

BB Bloemschikken $\quad 32$

BB Groene ruimte $\quad 10$

$\begin{array}{ll}\text { BB Bouw } & 9\end{array}$

BB Houtbewerking en woninginrichting $\quad 4$

BB Constructie-, plaatwerken/pijpenbewerken $\quad 14$

BB Machinebankwerken/verspanen $\quad 15$

BB Motorvoertuigen $\quad 29$

BB Energie- en informatietechniek 16

BB Installatie-, service- en onderhoudstechniek 23

BB Graf. techn, communicatie, audiovisueel en multimedia 39

BB Wegvervoer $\quad 15$

BB Detailhandel/ambulante handel $\quad 18$

BB Opslag/magazijn $\quad 25$

BB Horeca, instellingskeuken en contractcatering 23

BB Facilitaire dienstverlening $\quad 24$

BB Verpleging en verzorging $\quad 25$

BB Uiterlijke verzorging $\quad 9$

BBL niveau $3 / 4$

ZB Bloemschikken $\quad 9$

ZB Groene ruimte $\quad 9$

ZB Bouw $\quad 15$

ZB Grond-, water- en wegenbouw 11

ZB Beschermings- en afwerkingstechnieken $\quad 10$

$\begin{array}{ll}\text { ZB Motorvoertuigen } & 32\end{array}$

ZB Beheer, ontwerp en management (instal. techn) $\quad 5$

ZB Installatie-, service- en onderhoudstechniek $\quad 26$

ZB Procestechniek $r$

ZB Detailhandel/ambulante handel $\quad 22$

ZB Horeca, instellingskeuken en contractcatering $\quad 11$

ZB Verpleging en verzorging $\quad 17$

ZB Uiterlijke verzorging $\quad 10$

ZB Sociaal-pedagogisch werk 19

MKF Detailhandel/ambulante handel $\quad 21$

MKF Horeca, instellingskeuken en contractcatering $\quad 18$

MKF Verpleging en verzorging $\quad 21$

MKF Sociaal-pedagogisch werk $\quad 26$

Specialist Energietechniek $\quad 26$

Specialist Verpleging en verzorging 12

Zie ook toelichting bladzijde 47 
Tabel B3.14

Deelname aan een cursus of bedrijfsopleiding door werkende schoolverlaters

Opleidingsrichting

BOL niveau $1 / 2$

$A B$ Beveiliging

AB Detailhandel/ambulante handel

BB Bouw $\quad 39$

$\begin{array}{ll}\text { BB Houtbewerking en woninginrichting } & 17\end{array}$

BB Bedrijfsadministratie $\quad 39$

$\begin{array}{ll}\text { BB Beveiliging } & 10\end{array}$

BB Commercieel $\quad 19$

BB Secretarieel 33

$\begin{array}{ll}\text { BB Detailhandel/ambulante handel } & 27\end{array}$

BB Horeca, instellingskeuken en contractcatering $\quad 21$

$\begin{array}{ll}\text { BB Facilitaire dienstverlening } & 33\end{array}$

$\begin{array}{ll}\text { BB Verpleging en verzorging } & 17\end{array}$

BOL niveau $3 / 4$

ZB Plantenteelt

ZB Veehouderij

ZB Bloemschikken $\quad 10$

ZB Groene ruimte $\quad 26$

ZB Scheepvaart $\quad 38$

ZB Bedrijfsadministratief $\quad 35$

ZB Secretarieel $\quad 31$

ZB Detailhandel/ambulante handel $\quad 31$

ZB Verpleging en verzorging $\quad 28$

ZB Uiterlijke verzorging $\quad 39$

KF Plantenteelt

$\begin{array}{lr}\mathrm{KF} \text { Veehouderij } & 29 \\ \mathrm{KF} \text { BlomschkKen } & 12\end{array}$

KF Bloemschikken $\quad 12$

KF Groene ruimte $\quad 25$

KF Milieutoezicht $\quad 56$

MKF Bouw $\quad 54$

MKF Houtbewerking en woninginrichting $\quad 23$

MKF Grond-, water- en wegenbouw $\quad 60$

MKF Beschermings- en afwerkingstechnieken $\quad 14$

MKF Reclame, presentatie en communicatie $\quad 24$

$\begin{array}{lr}\text { MKF Werktuigbouwkunde } & 48\end{array}$

$\begin{array}{ll}\text { MKF Motorvoertuigen } & 68\end{array}$

$\begin{array}{ll}\text { MKF Energie- en informatietechniek } & 61\end{array}$

MKF Informatietechniek $\quad 57$

MKF Graf. techn, communicatie, audiovisueel en multimedia $\quad 26$

MKF Laboratoriumtechniek $\quad 35$

$\begin{array}{ll}\text { MKF Scheepvaart } & 42\end{array}$

$\begin{array}{ll}\text { MKF Transport en logistiek } & 49\end{array}$

MKF Bedrijfsadministratief $\quad 51$

MKF Commercieel $\quad 60$

MKF Economisch-juridisch $\quad 52$

MKF Secretarieel

MKF Detailhandel/ambulante handel $\quad 36$

MKF Groothandel/distributie $\quad 44$

MKF Horeca, instellingskeuken en contractcatering $\quad 30$

MKF Toerisme, recreatie en reizen $\quad 41$

$\begin{array}{ll}\text { MKF Assistenten gezondheidszorg } & 40\end{array}$

MKF Facilitaire dienstverlening $\quad 31$

MKF Sport en bewegen $\quad 40$

MKF Verpleging en verzorging $\quad 35$

MKF Maatschappelijke dienstverlening $\quad 48$

MKF Sociaal-pedagogisch werk algemeen $\quad 25$

$\begin{array}{ll}\text { MKF Sociaal-juridisch werk } & 44\end{array}$

Zie ook toelichting bladzijde 48 
Tabel B3.15

Belangrijkste cursussen of bedrijfsopleidingen waaraan werkende schoolverlaters deelnemen

\section{BOL AB Beveiliging}

BB, bedrijfszelfbescherming $\quad 30$

Weg-, railvervoer $\quad 17$

Recht 12

Secretarieel (incl. tekstverwerking, steno) $\quad 9$

Onderwijs

Toerisme

Gezondheidszorg

Administratief

Persoonlijke ontplooiing

BOL AB Detailhandel/ambulante handel

Marketing, reclame

Communicatie

Administratief

Detailhandel (incl. middenstandsdiploma)

BOL BB Bouw

Bouwkunde

BB, bedrijfszelfbescherming

Recht

Bedrijfskunde, management, efficiency

BOL BB Houtbewerking en woninginrichting

Algemeen

Bouwkunde

BOL BB Bedrijfsadministratie

Administratief

Bedrijfsadministratie, accountancy

Marketing, reclame

Verzekeringswezen

Communicatieve vaardigheden

Recht

Openbaar bestuur

BOL BB Beveiliging

Recht en openbare orde

$\mathrm{BB}$, bedrijfszelfbescherming

BOL BB Commercieel

Administratieve procesautomatisering $\quad 53$

Bedrijfsadministratie, accountancy 23

Recht en openbare orde $\quad 23$

BOL BB Secretarieel

Verzekeringswezen

Computer en informatica

Bedrijfskunde, management, efficiency

Recht

$\mathrm{BB}$, bedrijfszelfbescherming

BOL BB Detailhandel/ambulante handel

Weg-, railvervoer

Communicatieve vaardigheden

$\mathrm{BB}$, bedrijfszelfbescherming

Detailhandel (incl. middenstandsdiploma)

Economie

Administratief 
BOL BB Detailhandel/ambulante handel (vervolg)

Public relations

Marketing, reclame

Gezondheidszorg

Uiterlijke verzorging

Farmacie

BOL BB Horeca, instellingskeuken en contractcatering

Verzekeringswezen

Gezondheidszorg

Verpleging

Recht

Brandweer

Bedrijfskunde, management, efficiency

Horeca

Dietetiek

Communicatie

Secretarieel (incl. tekstverwerking, steno)

Marketing, reclame

Communicatieve vaardigheden

$\mathrm{BB}$, bedrijfszelfbescherming

BOL BB Facilitaire dienstverlening

Administratief

Detailhandel (incl. middenstandsdiploma)

Commercieel

BOL BB Verpleging en verzorging

Verpleging

Bejaardenverzorging

Sociaal werk

Algemeen

Bedrijfskunde, management, efficiency

BOL ZB Plantenteelt

Computer en informatica

Bedrijfskunde, management, efficiency

$\mathrm{BB}$, bedrijfszelfbescherming

Tuinbouw

BOL ZB Veehouderij

Procestechniek

Weg-, railvervoer

Bedrijfskunde, management, efficiency

$\mathrm{BB}$, bedrijfszelfbescherming

Marketing, reclame

Tuinbouw

Gezondheidszorg

Politie

BOL ZB Bloemschikken

Tuinbouw

$\mathrm{BB}$, bedrijfszelfbescherming

BOL ZB Groene ruimte

$B B$, bedrijfszelfbescherming

Bosbouw 
BOL ZB Groene ruimte (vervolg)

Ziekenverzorging

Recht

BOL ZB Scheepvaart

Scheepvaart

BB, bedrijfszelfbescherming

Leraren wiskunde, natuurwet., agrarische vakken

Weg-, railvervoer

Verpleging

Brandweer

BOL ZB Bedrijfsadministratief

Bedrijfsadministratie, accountancy

Recht en openbare orde

BOL ZB Secretarieel

Verzekeringswezen

Recht

Weg- en waterbouwkunde, landmeetkunde

Horeca

Romaanse talen

Computer en informatica

Persoonlijke ontplooiing

Communicatieve vaardigheden

BOL ZB Detailhandel/ambulante handel

Commercieel

Geneeskunde

Secretarieel (incl. tekstverwerking, steno)

Verzekeringswezen

BOL ZB Verpleging en verzorging

Verpleging

Gezondheidszorg

Geneeskunde

Gedrag en maatschappij

Maatschappelijk werk

BOL ZB Uiterlijke verzorging

Uiterlijke verzorging

Communicatieve vaardigheden

Gezondheidszorg

Bedrijfskunde, management, efficiency

Computer en informatica

BOL KF Plantenteelt

Weg-, railvervoer

Administratief

Computer en informatica

Geld- en bankzaken

Belastingen

BOL KF Veehouderij

Veeteelt 
BOL KF Veehouderij (vervolg)

Verpleging

Weg- en waterbouwkunde, landmeetkunde

Bedrijfsadministratie, accountancy

$\mathrm{BB}$, bedrijfszelfbescherming

Bedrijfskunde, management, efficiency

Gezondheidszorg

BOL KF Bloemschikken

Horeca

Bedrijfskunde, management, efficiency

Verpleging

Communicatieve vaardigheden

BOL KF Groene ruimte

Brandweer

$\mathrm{BB}$, bedrijfszelfbescherming

Romaanse talen

BOL KF Milieutoezicht

$\mathrm{BB}$, bedrijfszelfbescherming

Bouwkunde

Recht

Communicatieve vaardigheden

BOL MKF Bouw

$\mathrm{BB}$, bedrijfszelfbescherming

Computer en informatica

Bedrijfskunde, management, efficiency

Recht

Weg- en waterbouwkunde, landmeetkunde

Grafische techniek

Personeelswerk

BOL MKF Houtbewerking en woninginrichting

$\mathrm{BB}$, bedrijfszelfbescherming

Computer en informatica

Commercieel

Algemeen

Grafische techniek

Horeca

Persoonlijke ontplooiing

Beeldende kunst

BOL MKF Grond-, water- en wegenbouw

$\mathrm{BB}$, bedrijfszelfbescherming

Weg- en waterbouwkunde, landmeetkunde

Weg-, railvervoer

Algemeen

Procestechniek

Scheepvaart

Bedrijfskunde, management, efficiency

Bedrijfsadministratie, accountancy

Gezondheidszorg 
Tabel B3.15 (vervolg)

Belangrijkste cursussen of bedrijfsopleidingen waaraan werkende schoolverlaters deelnemen

BOL MKF Beschermings- en afwerkingstechnieken

$\mathrm{BB}$, bedrijfszelfbescherming

Techniek

BOL MKF Reclame, presentatie en communicatie

Computer en informatica

Elektrotechniek

Bouwkunde

Communicatie

Marketing, reclame

\section{BOL MKF Werktuigbouwkunde}

Bedrijfskunde, management, efficiency $r$

BB, bedrijfszelfbescherming $\quad 18$

Computer en informatica 13

Elektrische energietechniek $\quad 12$

Elektrotechniek

BOL MKF Motorvoertuigen

Elektrotechniek

Techniek 31

Sociaal werk

Elektrische energietechniek

Bedrijfskunde, management, efficiency

Verzekeringswezen

BOL MKF Energie- en informatietechniek

$\mathrm{BB}$, bedrijfszelfbescherming

Telecommunicatie/datacommunicatie

Computer en informatica

Elektrotechniek

Techniek

Bedrijfskunde, management, efficiency

BOL MKF Informatietechniek

Computer en informatica

Telecommunicatie/datacommunicatie

Nederlands

BOL MKF Graf. techn, communicatie, audiovisueel en multimedia

Marketing, reclame

Grafische techniek

Secretarieel (incl. tekstverwerking, steno)

Computer en informatica

Politie

\section{BOL MKF Laboratoriumtechniek}

Techniek

Computer en informatica

$\mathrm{BB}$, bedrijfszelfbescherming

Geneeskunde

Elektrische energietechniek

Laboratoriumpersoneel

Administratief

Gezondheidszorg

Germaanse talen

Scheikunde 
Tabel B3.15 (vervolg)

Belangrijkste cursussen of bedrijfsopleidingen waaraan werkende schoolverlaters deelnemen

BOL MKF Scheepvaart

$\mathrm{BB}$, bedrijfszelfbescherming

Brandweer

Zeemacht

BOL MKF Transport en logistiek

Bedrijfskunde, management, efficiency $\quad 15$

Weg-, railvervoer $\quad 14$

Luchtvaart $\quad 13$

Computer en informatica

Secretarieel (incl. tekstverwerking, steno)

Marketing, reclame

BOL MKF Bedrijfsadministratief

Geld- en bankzaken

Belastingen

Bedrijfskunde, management, efficiency

Administratief

Bedrijfsadministratie, accountancy

Communicatieve vaardigheden

$\mathrm{BB}$, bedrijfszelfbescherming

BOL MKF Commercieel

Verzekeringswezen

Geld- en bankzaken

Belastingen

BOL MKF Economisch-juridisch

Recht

Computer en informatica

Germaanse talen

Administratief

Geld- en bankzaken

Verzekeringswezen

Recht en openbare orde

Politie

$\mathrm{BB}$, bedrijfszelfbescherming

BOL MKF Secretarieel

Geld- en bankzaken

Bedrijfskunde, management, efficiency

Recht

Telecommunicatie/datacommunicatie

Administratief

Computer en informatica

Bedrijfsadministratie, accountancy

Germaanse talen

BOL MKF Detailhandel/ambulante handel

Bedrijfskunde, management, efficiency

Computer en informatica

Uiterlijke verzorging

Detailhandel (incl. middenstandsdiploma)

Marketing, reclame

BOL MKF Groothandel/distributie

Verzekeringswezen

Marketing, reclame 
Tabel B3.15 (vervolg)

Belangrijkste cursussen of bedrijfsopleidingen waaraan werkende schoolverlaters deelnemen

BOL MKF Groothandel/distributie (vervolg)

Computer en informatica

Elektronica algemeen/radio-TV

Administratief

Detailhandel (incl. middenstandsdiploma)

$\mathrm{BB}$, bedrijfszelfbescherming

BOL MKF Horeca, instellingskeuken en contractcatering

Bedrijfskunde, management, efficiency

Marketing, reclame

$\mathrm{BB}$, bedrijfszelfbescherming

Toerisme

Computer en informatica

Horeca

BOL MKF Toerisme, recreatie en reizen

Toerisme

Luchtvaart

Communicatie

Bedrijfskunde, management, efficiency

Marketing, reclame

Geld- en bankzaken

Verzekeringswezen

Horeca

Germaanse talen

Romaanse talen

Recht

BOL MKF Assistenten gezondheidszorg

Geneeskunde

Verpleging

Gezondheidszorg

Tandheelkunde

BOL MKF Facilitaire dienstverlening

$\mathrm{BB}$, bedrijfszelfbescherming

Toerisme

Belastingen

Computer en informatica

Administratief

Geld- en bankzaken

Horeca

Verpleging

Communicatieve vaardigheden

BOL MKF Sport en bewegen

Gezondheidszorg

Gedrag en maatschappij

Hobbycursus

Onderwijs

Algemeen

$\mathrm{BB}$, bedrijfszelfbescherming

BOL MKF Verpleging en verzorging

$\mathrm{BB}$, bedrijfszelfbescherming

Verpleging

Pedagog.-didactische cursussen voor leerkrachten

Ziekenverzorging

Gezondheidszorg 
Tabel B3.15 (vervolg)

Belangrijkste cursussen of bedrijfsopleidingen waaraan werkende schoolverlaters deelnemen

BOL MKF Verpleging en verzorging (vervolg)

Computer en informatica

Medisch secretarieel

Gedrag en maatschappij

BOL MKF Maatschappelijke dienstverlening

Verzekeringswezen

Medisch secretariee

BOL MKF Sociaal-pedagogisch werk algemeen

Verpleging

Communicatieve vaardigheden

Gezondheidszorg

$\mathrm{BB}$, bedrijfszelfbescherming

Geneeskunde

Gedrag en maatschappij

BOL MKF Sociaal-juridisch werk

Onderwijs

Leraren wiskunde, natuurwet., agrarische vakken

Computer en informatica

Administratief

Communicatieve vaardigheden

Recht

Politie

Zie ook toelichting bladzijde 51 


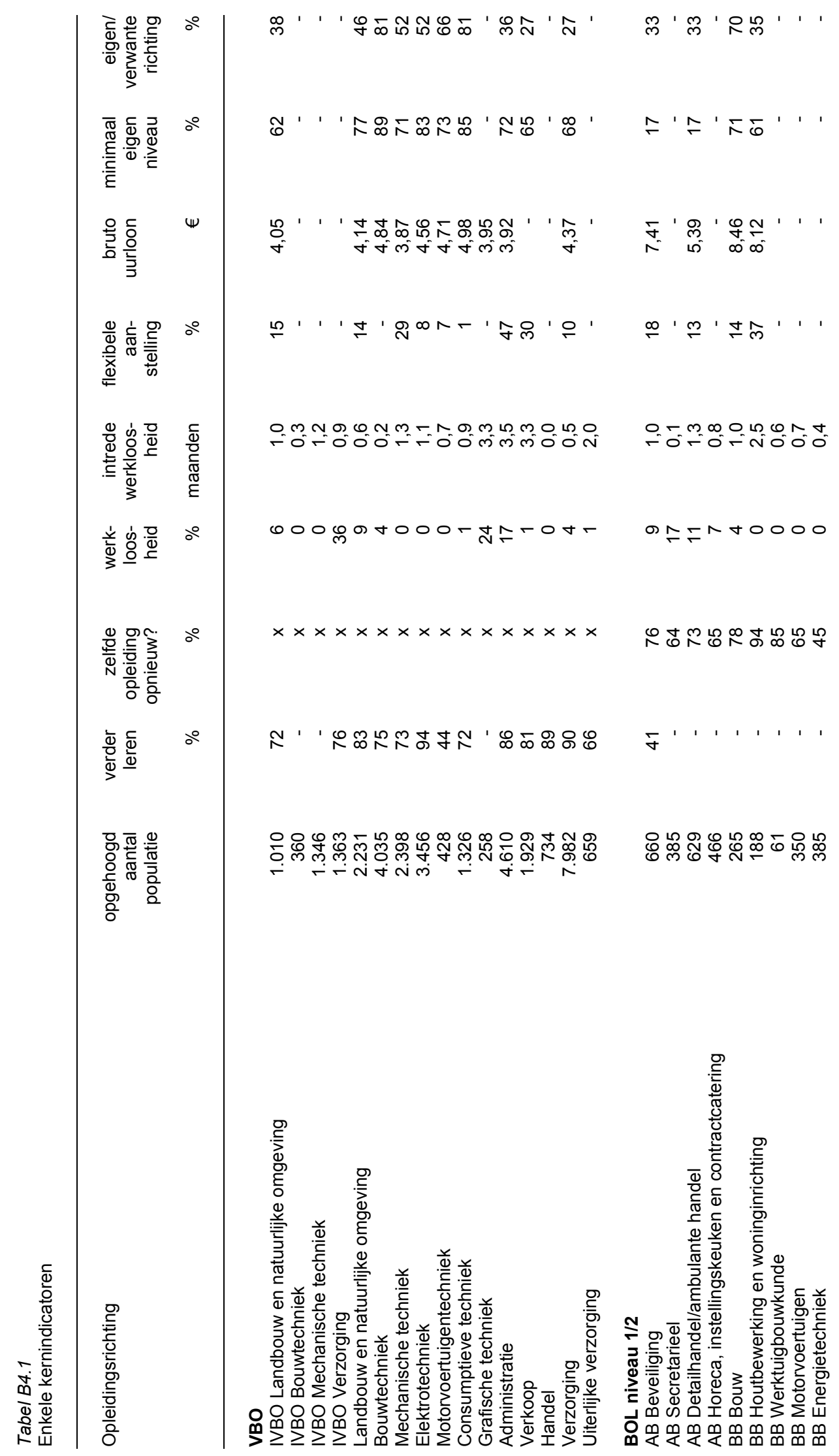




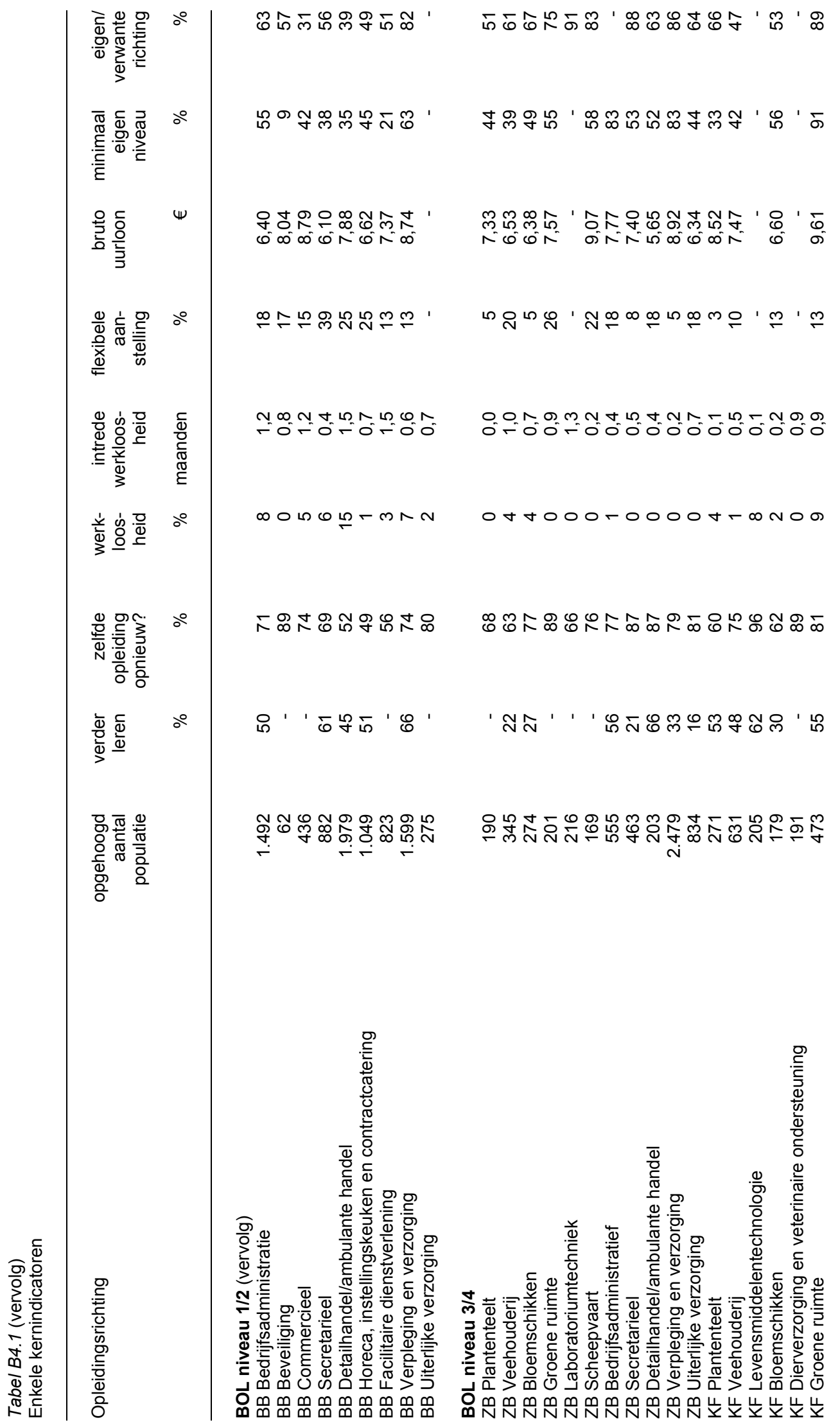




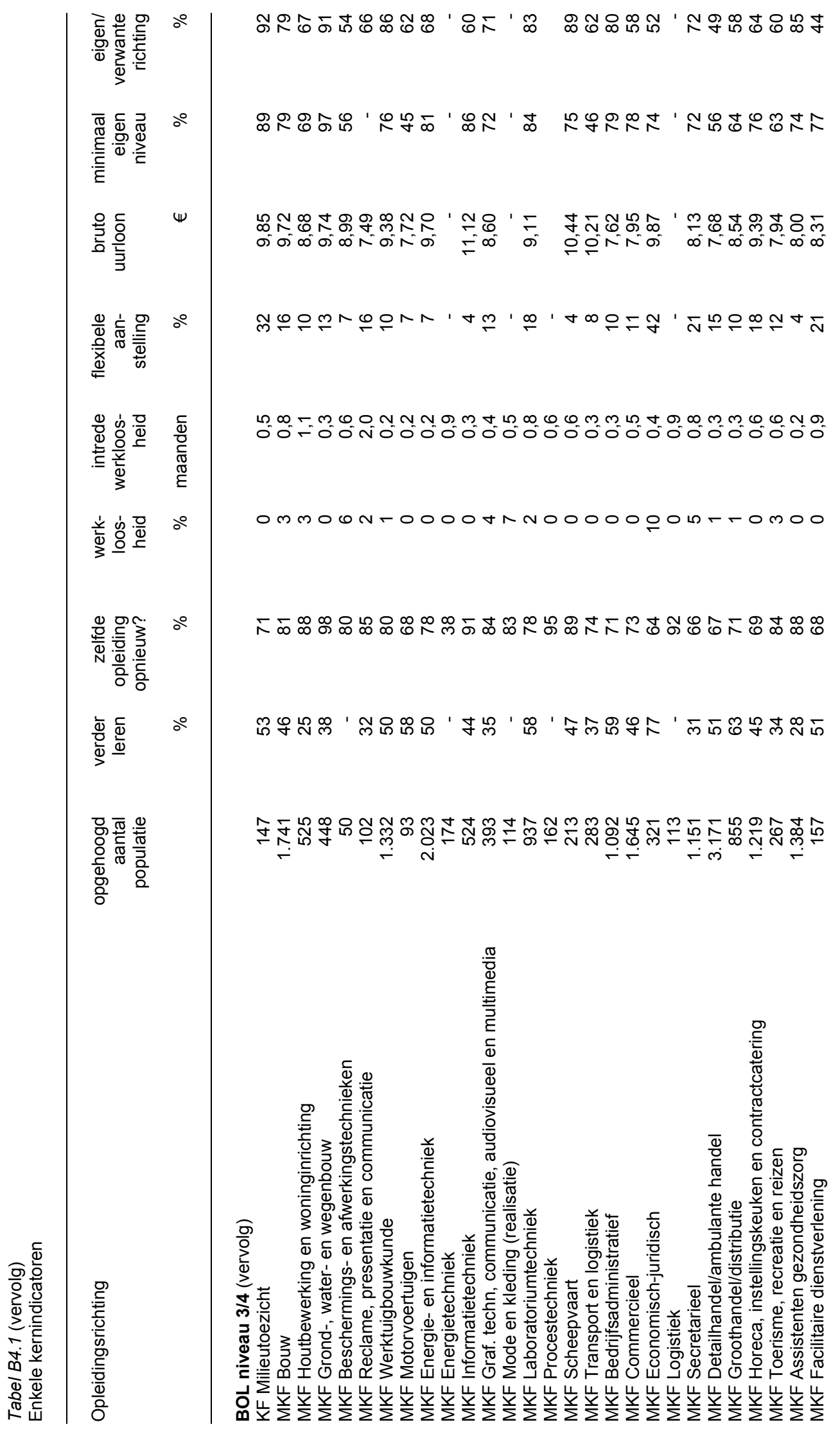




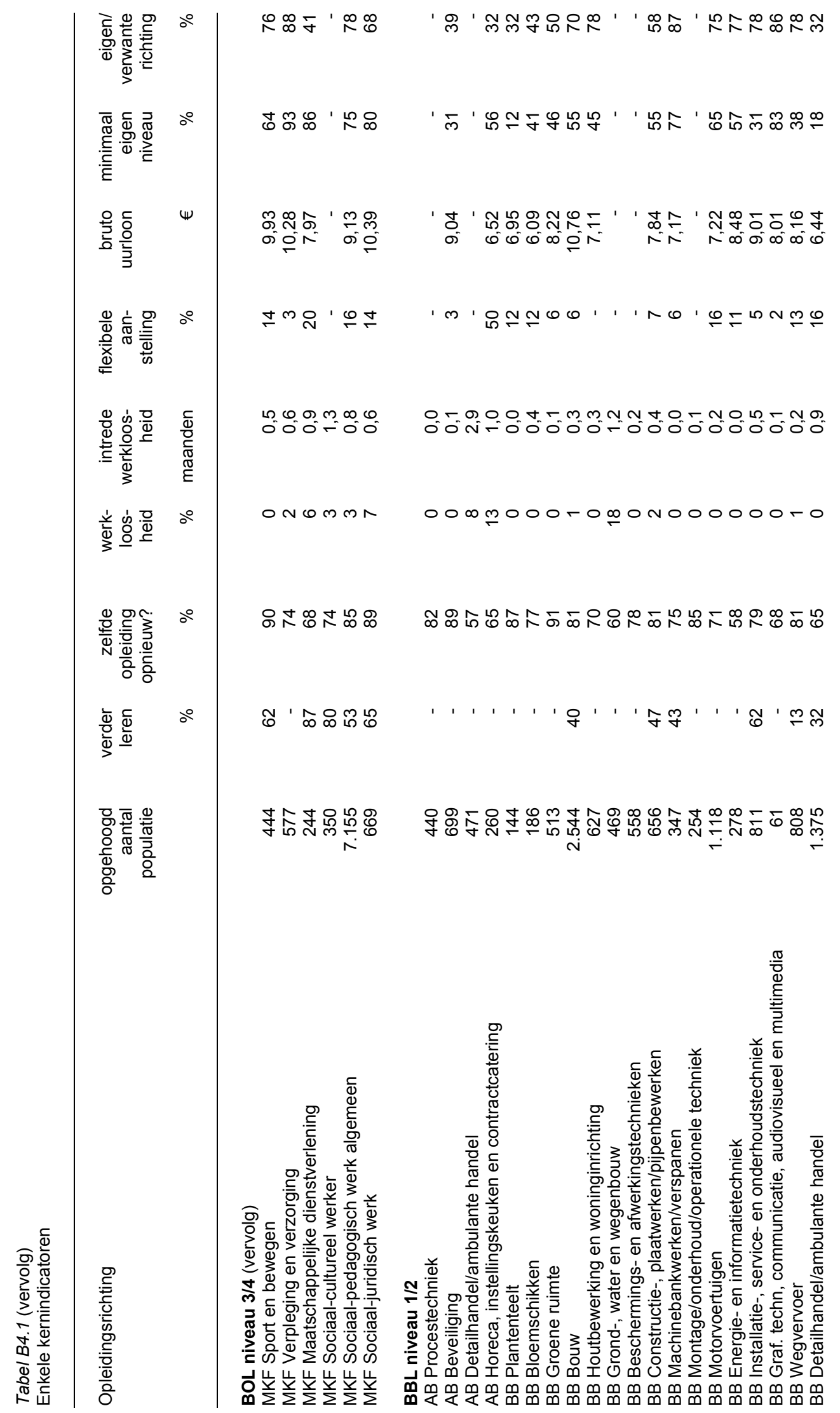




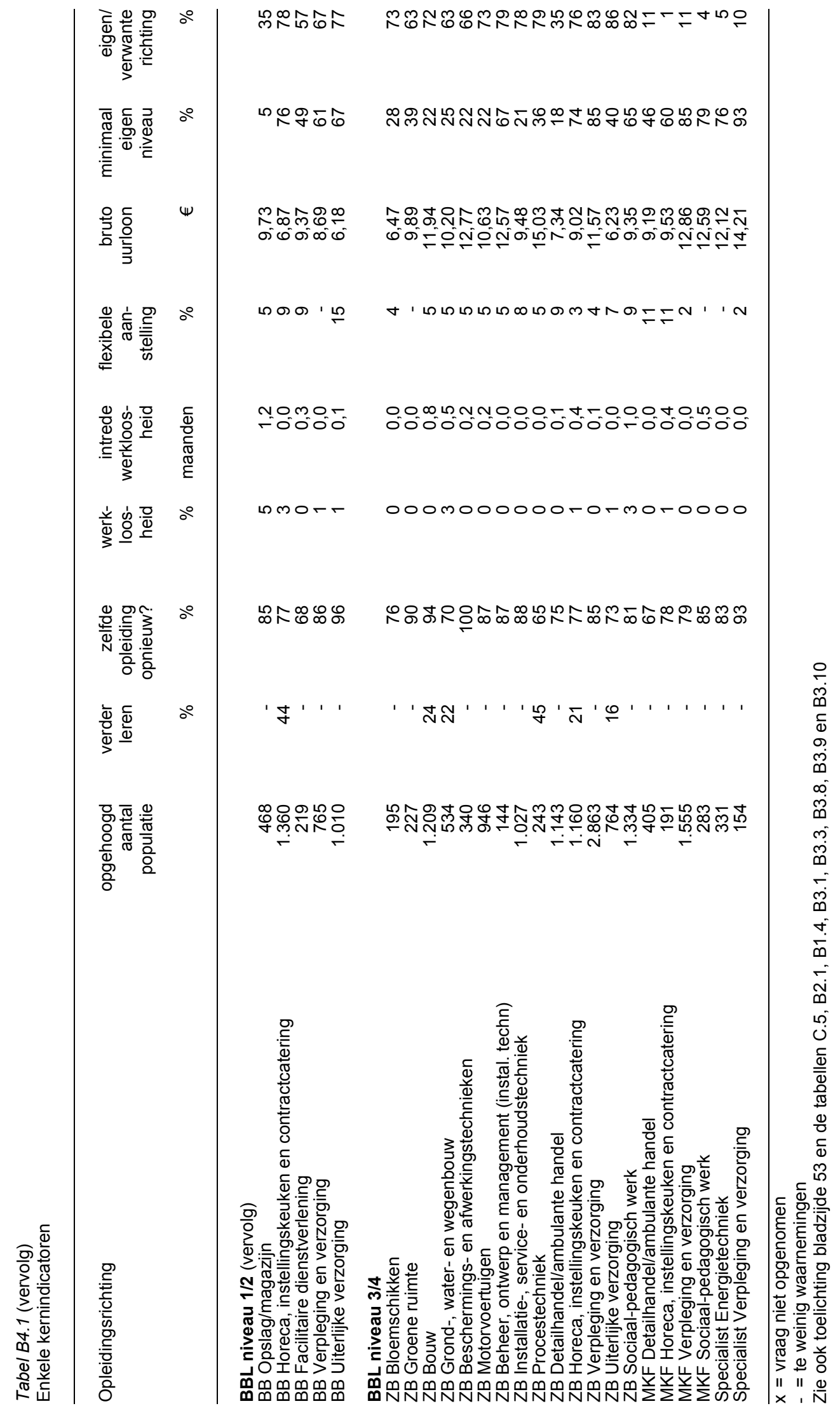


C. Respons 



\section{Inhoud}

C.1 Ongewogen aantal respondenten verbijzonderd naar bestemming per opleidingssector

C.2 Naar landelijke populatie gewogen aantal schoolverlaters verbijzonderd naar bestemming per opleidingssector

C.3 Responspercentage per opleidingssector

C.4 Ongewogen aantal respondenten verbijzonderd naar bestemming per opleidingsrichting

C.5 Naar landelijke populatie gewogen aantal schoolverlaters verbijzonderd naar bestemming per opleidingsrichting

C.6 Responspercentage per opleidingsrichting 
Tabel C.1

Ongewogen aantal respondenten verbijzonderd naar bestemming per opleidingssector

\begin{tabular}{|c|c|c|c|c|c|c|c|}
\hline Opleidingssector & studie & BBL & $\begin{array}{r}\text { betaald } \\
\text { werk }\end{array}$ & $\begin{array}{c}\text { werk- } \\
\text { loos }\end{array}$ & anders & $\begin{array}{r}\text { on- } \\
\text { bekend }\end{array}$ & totaal \\
\hline AVO & 3.342 & 188 & 369 & 34 & 107 & 69 & 4.109 \\
\hline MAVO & 1.113 & 141 & 166 & 14 & 48 & 31 & 1.513 \\
\hline HAVO & 1.209 & 36 & 158 & 17 & 39 & 25 & 1.484 \\
\hline VWO & 1.020 & 11 & 45 & 3 & 20 & 13 & 1.112 \\
\hline VBO & 690 & 251 & 420 & 32 & 64 & 29 & 1.486 \\
\hline IVBO & 76 & 60 & 78 & 8 & 11 & 7 & 240 \\
\hline Landbouw & 230 & 62 & 139 & 10 & 18 & 3 & 462 \\
\hline Techniek & 108 & 75 & 94 & 4 & 11 & 4 & 296 \\
\hline Economie & 140 & 25 & 55 & 4 & 14 & 9 & 247 \\
\hline Gezondheidszorg & 136 & 29 & 54 & 6 & 10 & 6 & 241 \\
\hline BOL niveau $1 / 2$ & 201 & 66 & 511 & 38 & 39 & 14 & 869 \\
\hline Landbouw & 3 & 2 & 38 & 0 & 0 & 1 & 44 \\
\hline Techniek & 35 & 18 & 116 & 8 & 9 & 0 & 186 \\
\hline Economie & 118 & 28 & 284 & 24 & 26 & 10 & 490 \\
\hline Gezondheidszorg & 45 & 18 & 73 & 6 & 4 & 3 & 149 \\
\hline BOL niveau $3 / 4$ & 1.551 & 83 & 3.109 & 50 & 140 & 36 & 4.969 \\
\hline Landbouw & 165 & 13 & 421 & 8 & 16 & 8 & 631 \\
\hline Techniek & 443 & 7 & 788 & 13 & 23 & 10 & 1.284 \\
\hline Economie & 386 & 16 & 699 & 13 & 34 & 6 & 1.154 \\
\hline Gezondheidszorg & 161 & 32 & 591 & 5 & 21 & 6 & 816 \\
\hline Gedrag en maatschappij & 396 & 15 & 610 & 11 & 46 & 6 & 1.084 \\
\hline BBL niveau 1/2 & 32 & 93 & 939 & 13 & 53 & 14 & 1.144 \\
\hline Landbouw & 1 & 5 & 136 & 1 & 7 & 1 & 151 \\
\hline Techniek & 21 & 59 & 550 & 6 & 34 & 8 & 678 \\
\hline Economie & 10 & 18 & 178 & 5 & 11 & 3 & 225 \\
\hline Gezondheidszorg & 0 & 11 & 75 & 1 & 1 & 2 & 90 \\
\hline BBL niveau $3 / 4$ & 39 & 31 & 1.344 & 13 & 68 & 14 & 1.509 \\
\hline Landbouw & 3 & 3 & 131 & 1 & 8 & 2 & 148 \\
\hline Techniek & 11 & 8 & 424 & 4 & 14 & 7 & 468 \\
\hline Economie & 13 & 2 & 288 & 5 & 12 & 0 & 320 \\
\hline Gezondheidszorg & 6 & 17 & 323 & 1 & 16 & 1 & 364 \\
\hline Gedrag en maatschappij & 6 & 1 & 178 & 2 & 18 & 4 & 209 \\
\hline HBO & 2.207 & $\mathbf{x}$ & 13.501 & 281 & 447 & 471 & 16.907 \\
\hline Landbouw & 108 & $\mathrm{x}$ & 651 & 25 & 27 & 27 & 838 \\
\hline Onderwijs & 205 & $\mathrm{x}$ & 2.513 & 22 & 52 & 37 & 2.829 \\
\hline Techniek & 563 & $\mathrm{x}$ & 2.595 & 57 & 51 & 63 & 3.329 \\
\hline Economie & 766 & $\mathrm{x}$ & 3.548 & 84 & 104 & 99 & 4.601 \\
\hline Gezondheidszorg & 203 & $\mathrm{x}$ & 1.728 & 19 & 47 & 56 & 2.053 \\
\hline Gedrag en maatschappij & 276 & $\mathrm{x}$ & 1.995 & 54 & 58 & 64 & 2.447 \\
\hline Kunst en cultuur & 86 & $x$ & 471 & 20 & 108 & 125 & 810 \\
\hline wo & 281 & $\mathbf{x}$ & 7.520 & 174 & 282 & 138 & 8.395 \\
\hline Landbouw & 7 & $\mathrm{x}$ & 186 & 5 & 6 & 3 & 207 \\
\hline Techniek & 23 & $\mathrm{x}$ & 1.042 & 26 & 23 & 15 & 1.129 \\
\hline Economie & 20 & $\mathrm{x}$ & 1.219 & 15 & 24 & 14 & 1.292 \\
\hline Gezondheidszorg & 53 & $\mathrm{x}$ & 935 & 17 & 35 & 21 & 1.061 \\
\hline Gedrag en maatschappij & 58 & $\mathrm{x}$ & 1.604 & 35 & 71 & 29 & 1.797 \\
\hline Taal en cultuur & 44 & $\mathrm{x}$ & 849 & 35 & 76 & 20 & 1.024 \\
\hline
\end{tabular}


Tabel C. 1 (vervolg)

Ongewogen aantal respondenten verbijzonderd naar bestemming per opleidingssector

\begin{tabular}{lrrrrrrr}
\hline Opleidingssector & studie & BBL & $\begin{array}{r}\text { betaald } \\
\text { werk }\end{array}$ & $\begin{array}{r}\text { werk- } \\
\text { loos }\end{array}$ & anders & $\begin{array}{r}\text { on- } \\
\text { bekend }\end{array}$ & totaal \\
\hline wo (vervolg) & & & & & & & \\
Recht en openbare orde & 28 & $\mathrm{x}$ & 1.056 & 26 & 24 & 24 & 1.158 \\
Natuurwetenschappen & 48 & $\mathrm{x}$ & 629 & 15 & 23 & 12 & 727 \\
Totaal & $\mathbf{8 . 3 4 3}$ & $\mathbf{7 1 2}$ & $\mathbf{2 7 . 7 1 3}$ & $\mathbf{6 3 5}$ & $\mathbf{1 . 2 0 0}$ & $\mathbf{7 8 5}$ & $\mathbf{3 9 . 3 8 8}$ \\
\hline
\end{tabular}

$\mathrm{x}=$ antwoordcategorie niet opgenomen

Toelichting

De aantallen in deze tabel betreffen het feitelijke aantal respondenten van wie de gegevens in de analyses zijn opgenomen. 
Tabel C.2

Naar landelijke populatie gewogen aantal schoolverlaters verbijzonderd naar bestemming per opleidingssector

\begin{tabular}{|c|c|c|c|c|c|c|c|}
\hline & studie & BBL & $\begin{array}{r}\text { betaald } \\
\text { werk }\end{array}$ & $\begin{array}{r}\text { wer- } \\
\text { kloos }\end{array}$ & anders & $\begin{array}{l}\text { on- } \\
\text { bekend }\end{array}$ & totaal \\
\hline AVO & 80.499 & 4.915 & 8.179 & 600 & 2.345 & 488 & 97.028 \\
\hline MAVO & 30.852 & 4.104 & 3.959 & 212 & 1.572 & 246 & 40.943 \\
\hline HAVO & 27.645 & 575 & 3.360 & 381 & 550 & 175 & 32.686 \\
\hline VWO & 22.003 & 237 & 861 & 8 & 223 & 68 & 23.399 \\
\hline VBO & 17.541 & 7.011 & 8.915 & 667 & 1.273 & 196 & 35.603 \\
\hline IVBO & 1.723 & 1.397 & 1.248 & 234 & 67 & 53 & 4.723 \\
\hline Landbouw & 1.132 & 294 & 658 & 59 & 95 & 5 & 2.242 \\
\hline Techniek & 4.573 & 3.514 & 3.570 & 120 & 332 & 50 & 12.159 \\
\hline Economie & 4.097 & 861 & 1.809 & 169 & 369 & 14 & 7.318 \\
\hline Gezondheidszorg & 6.017 & 945 & 1.630 & 85 & 410 & 74 & 9.161 \\
\hline BOL niveau $1 / 2$ & 3.637 & 1.165 & 7.295 & 490 & 514 & 205 & 13.305 \\
\hline Landbouw & 11 & 11 & 232 & 0 & 0 & 1 & 254 \\
\hline Techniek & 436 & 333 & 1.315 & 70 & 101 & 0 & 2.255 \\
\hline Economie & 2.298 & 491 & 4.442 & 337 & 346 & 178 & 8.093 \\
\hline Gezondheidszorg & 892 & 330 & 1.306 & 82 & 67 & 26 & 2.703 \\
\hline BOL niveau 3/4 & 12.926 & 694 & 24.366 & 308 & 1075 & 181 & 39.550 \\
\hline Landbouw & 929 & 68 & 2.242 & 39 & 85 & 31 & 3.393 \\
\hline Techniek & 3.661 & 75 & 6.033 & 80 & 144 & 50 & 10.044 \\
\hline Economie & 4.149 & 163 & 7.029 & 78 & 317 & 25 & 11.761 \\
\hline Gezondheidszorg & 1.020 & 255 & 4.404 & 20 & 150 & 53 & 5.901 \\
\hline Gedrag en maatschappij & 3.167 & 133 & 4.659 & 92 & 379 & 21 & 8.451 \\
\hline BBL niveau $1 / 2$ & 590 & 1.833 & 15.172 & 275 & 920 & 272 & 19.062 \\
\hline Landbouw & 4 & 44 & 956 & 11 & 51 & 8 & 1.074 \\
\hline Techniek & 305 & 1.133 & 8.811 & 165 & 609 & 159 & 11.183 \\
\hline Economie & 281 & 480 & 3.647 & 94 & 238 & 68 & 4.809 \\
\hline Gezondheidszorg & 0 & 176 & 1.757 & 5 & 21 & 37 & 1.997 \\
\hline BBL niveau $3 / 4$ & 417 & 367 & 16.523 & 106 & 865 & 118 & 18.397 \\
\hline Landbouw & 8 & 18 & 692 & 2 & 44 & 11 & 775 \\
\hline Techniek & 147 & 113 & 6.240 & 40 & 272 & 82 & 6.895 \\
\hline Economie & 161 & 32 & 3.376 & 42 & 126 & 0 & 3.738 \\
\hline Gezondheidszorg & 52 & 200 & 4.844 & 4 & 271 & 1 & 5.372 \\
\hline Gedrag en maatschappij & 48 & 4 & 1.371 & 17 & 151 & 24 & 1.617 \\
\hline HBO & 5.964 & $\mathbf{x}$ & 35.306 & 770 & 1.231 & 1.228 & 44.499 \\
\hline Landbouw & 274 & $\mathrm{x}$ & $1 . .669$ & 55 & 74 & 66 & 2.139 \\
\hline Onderwijs & 498 & $\mathrm{x}$ & 6.141 & 56 & 133 & 87 & 6.914 \\
\hline Techniek & 1.599 & $\mathrm{x}$ & 7.736 & 179 & 150 & 167 & 9.831 \\
\hline Economie & 2.180 & $\mathrm{x}$ & 10.030 & 236 & 278 & 267 & 12.991 \\
\hline Gezondheidszorg & 410 & $\mathrm{x}$ & 3.516 & 40 & 100 & 112 & 4.177 \\
\hline Gedrag en maatschappij & 665 & $\mathrm{x}$ & 4.701 & 134 & 136 & 153 & 5.788 \\
\hline Kunst en cultuur & 339 & $x$ & 1.513 & 71 & 360 & 377 & 2.660 \\
\hline wo & 619 & $\mathbf{x}$ & 16.574 & 384 & 622 & 304 & 18.503 \\
\hline Landbouw & 15 & $\mathrm{x}$ & 410 & 11 & 13 & 7 & 456 \\
\hline Techniek & 51 & $\mathrm{x}$ & 2.297 & 57 & 51 & 33 & 2.488 \\
\hline Economie & 44 & $\mathrm{x}$ & 2.687 & 33 & 53 & 31 & 2.848 \\
\hline Gezondheidszorg & 117 & $\mathrm{x}$ & 2.061 & 37 & 77 & 46 & 2.339 \\
\hline Gedrag en maatschappij & 128 & $\mathrm{x}$ & 3.535 & 77 & 156 & 64 & 3.961 \\
\hline Taal en cultuur & 97 & $\mathrm{x}$ & 1.871 & 77 & 168 & 44 & 2.257 \\
\hline
\end{tabular}


Tabel C.2 (vervolg)

Naar landelijke populatie gewogen aantal schoolverlaters verbijzonderd naar bestemming per opleidingssector

\begin{tabular}{|c|c|c|c|c|c|c|c|}
\hline & studie & BBL & $\begin{array}{r}\text { betaald } \\
\text { werk }\end{array}$ & $\begin{array}{l}\text { wer- } \\
\text { kloos }\end{array}$ & anders & $\begin{array}{l}\text { on- } \\
\text { bekend }\end{array}$ & totaal \\
\hline \multicolumn{8}{|l|}{ WO (vervolg) } \\
\hline Recht en openbare orde & 62 & $\mathrm{x}$ & 2.327 & 57 & 53 & 53 & 2.552 \\
\hline Natuurwetenschappen & 106 & $x$ & 1.386 & 33 & 51 & 26 & 1.602 \\
\hline Totaal & 122.194 & 15.986 & 132.331 & 3.600 & 8.844 & 2.992 & 285.948 \\
\hline
\end{tabular}

$\mathrm{x}=$ antwoordcategorie niet opgenomen

Toelichting

De aantallen in deze tabel zijn zodanig opgehoogd dat een representatief beeld wordt gegeven van de totale populatie van schoolverlaters. 
Tabel C.3

Responspercentage per opleidingssector

Opleidingssector

AVO

MAVO

HAVO

VWO

vBO

IVBO

Landbouw

Techniek

Economie

Gezondheidszorg

BOL niveau $1 / 2$

Landbouw

Techniek

29

Economie

Gezondheidszorg

BOL niveau $3 / 4$

Landbouw

Techniek

Economie 32

Gezondheidszorg

Gedrag en maatschappij

BBL niveau 1/2

Landbouw

Ttechniek

Economie

Gezondheidszorg

21

BBL niveau 3/4

Landbouw

31

Techniek

Economie

26

Gezondheidszorg

29

Gedrag en maatschappij

HBO

Landbouw

Onderwijs

Techniek

Economie

Gezondheidszorg

Gedrag en maatschappij

Taal en cultuur

WO totaal

Landbouw

Techniek

Economie

Gezondheidszorg

Gedrag en maatschappij

Taal en cultuur 
Tabel C.3 (vervolg)

Responspercentage per opleidingssector

Opleidingssector

WO (vervolg)

Recht en openbare orde

Natuurwetenschappen

53

Totaal

Toelichting

De responspercentages geven een beeld van het aandeel van de uitgezette vragenlijsten dat bruikbaar retour is gekomen. De responspercentages van het WO hebben betrekking op 12 universiteiten. 


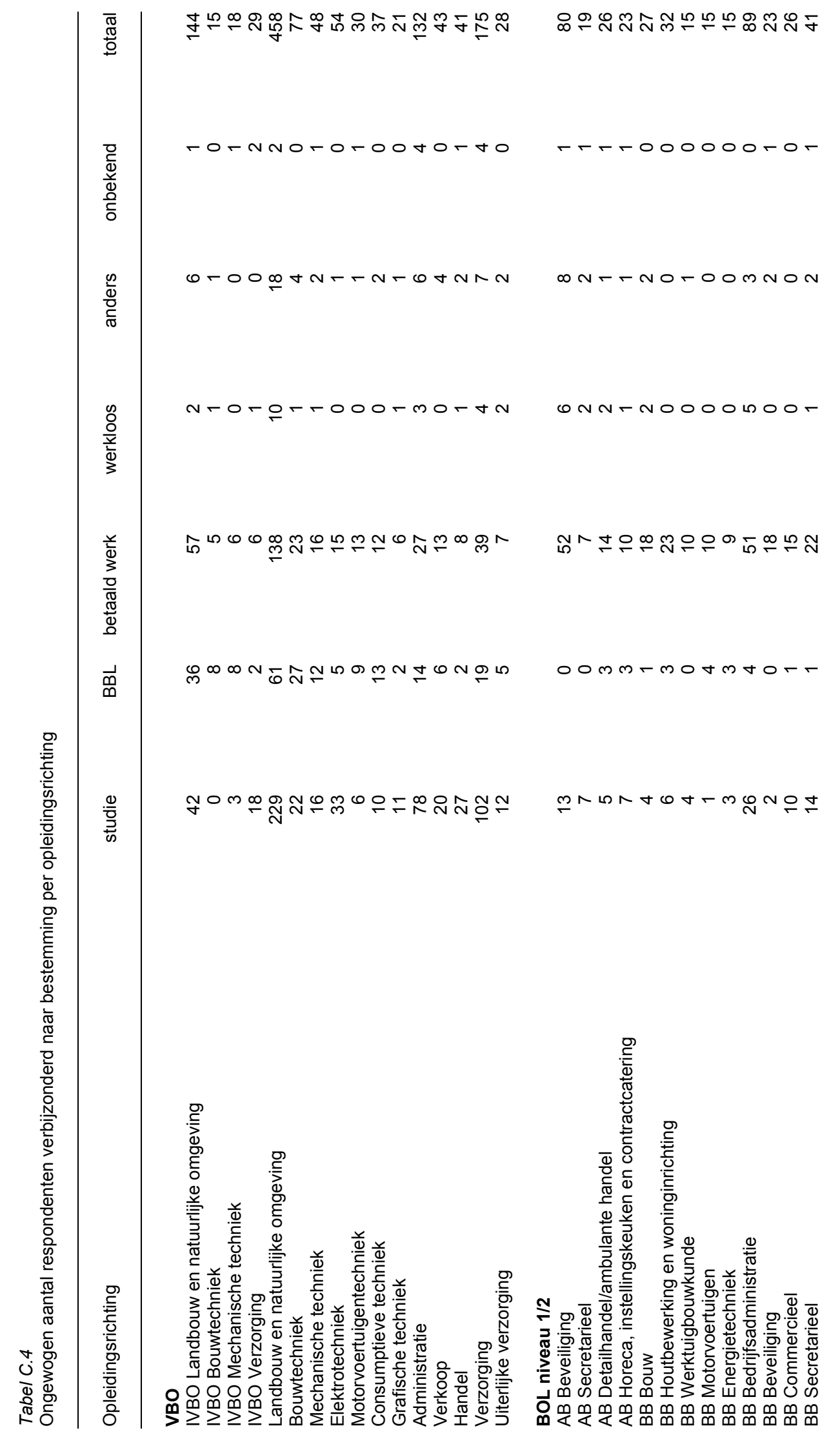




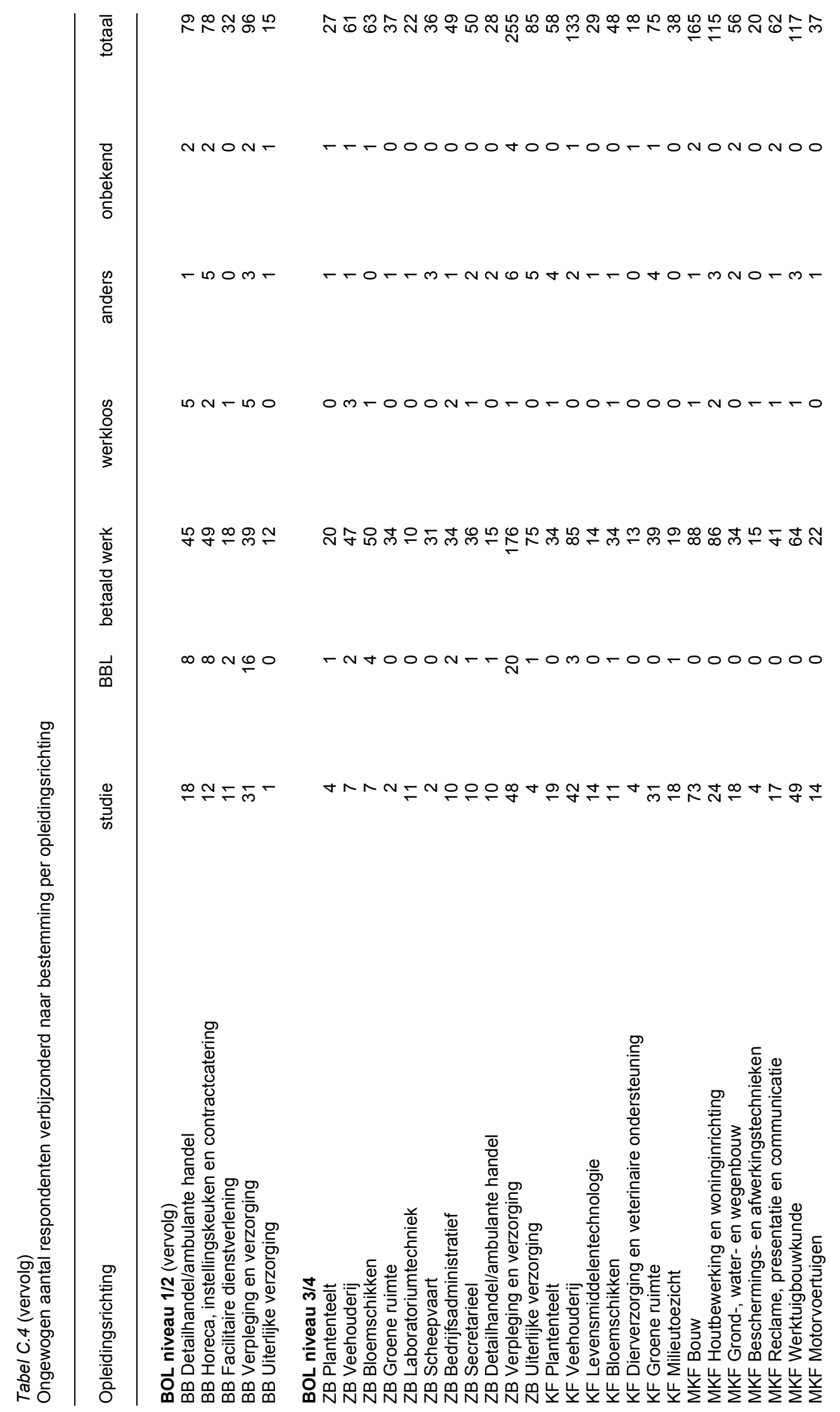




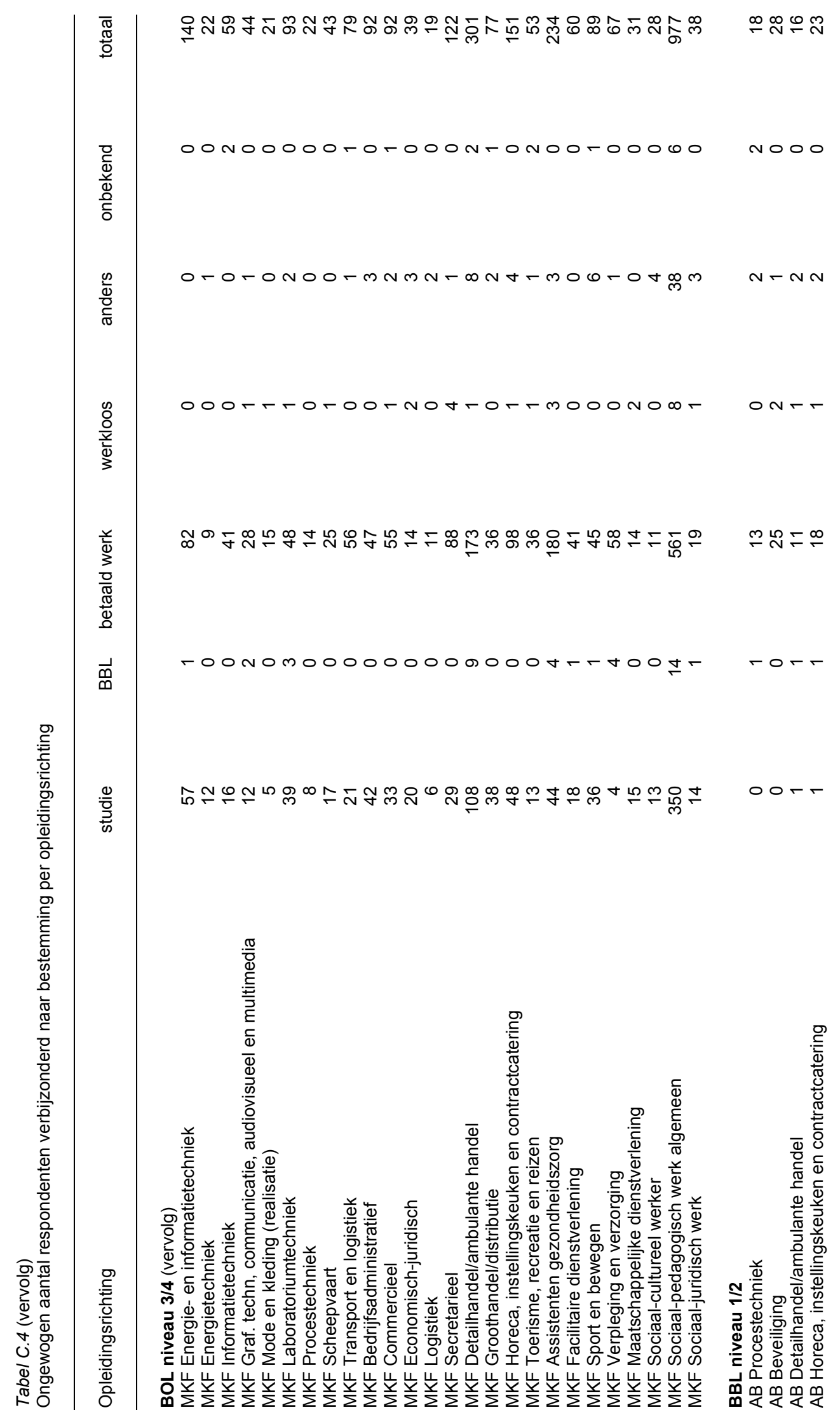




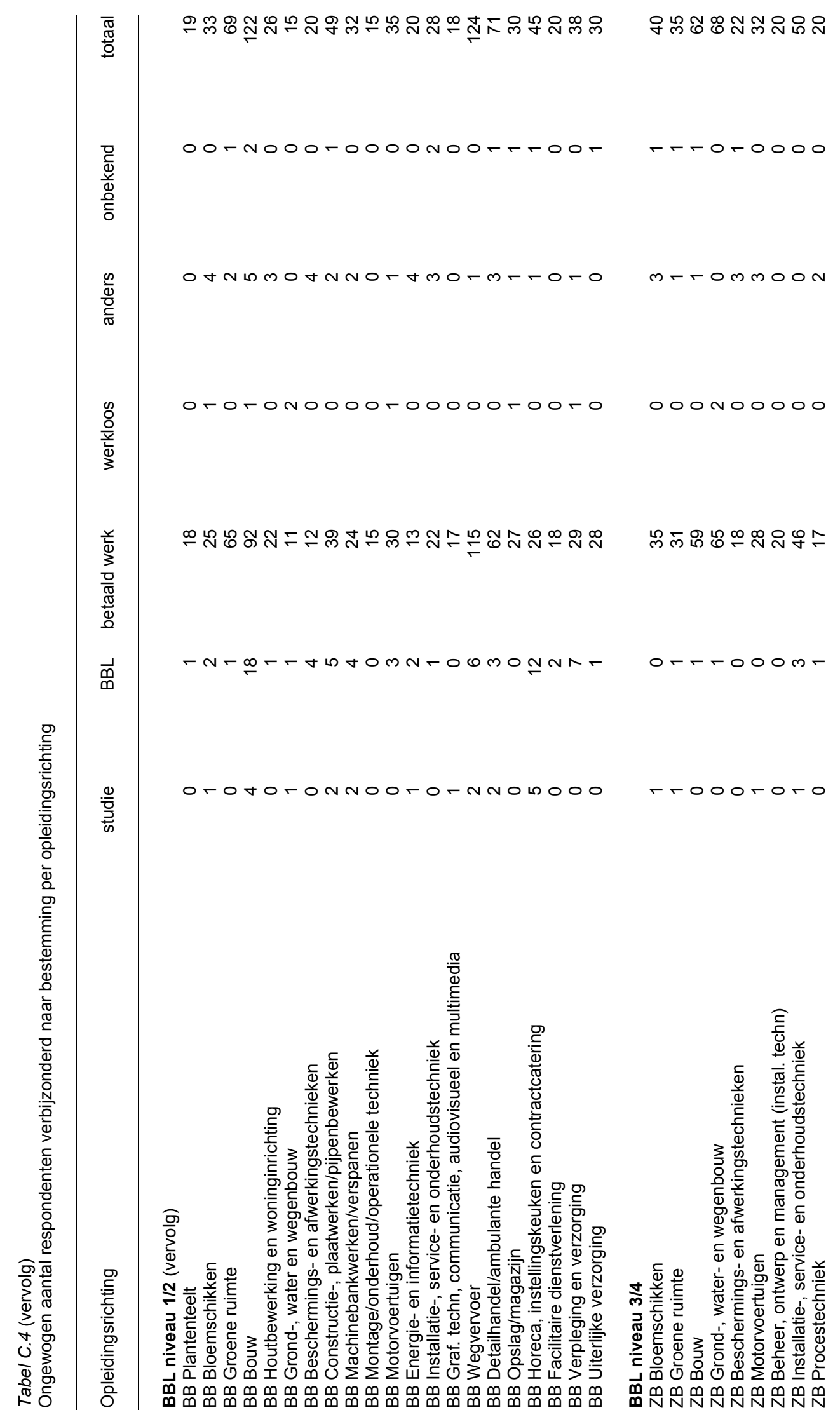




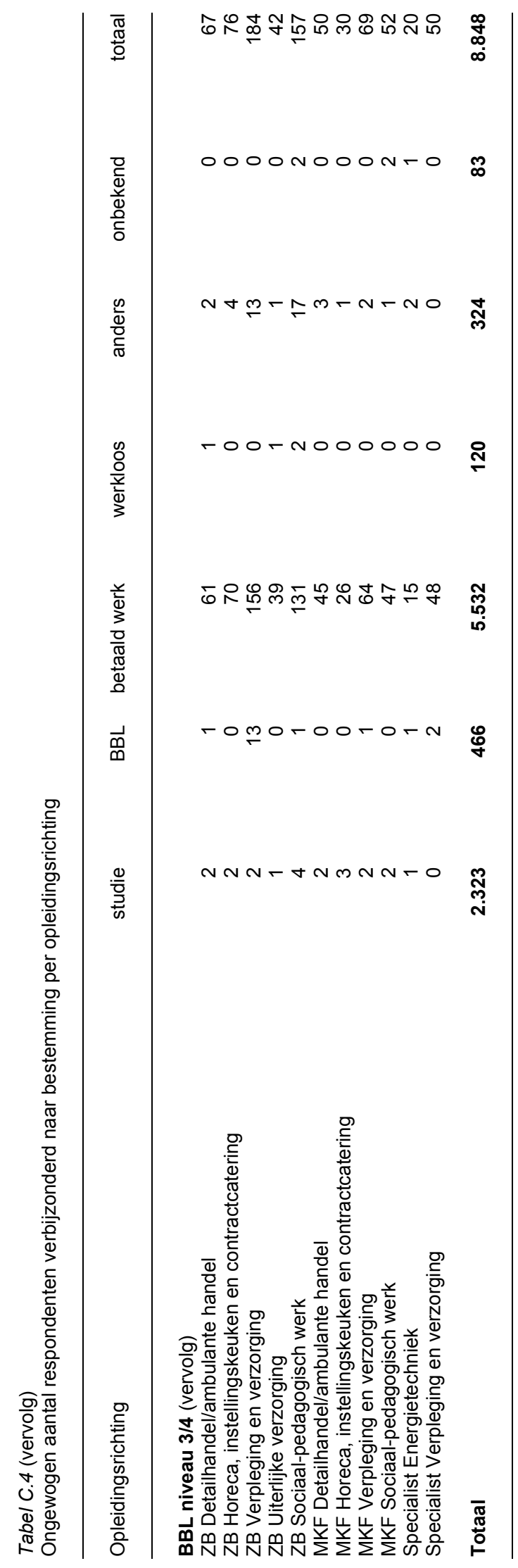




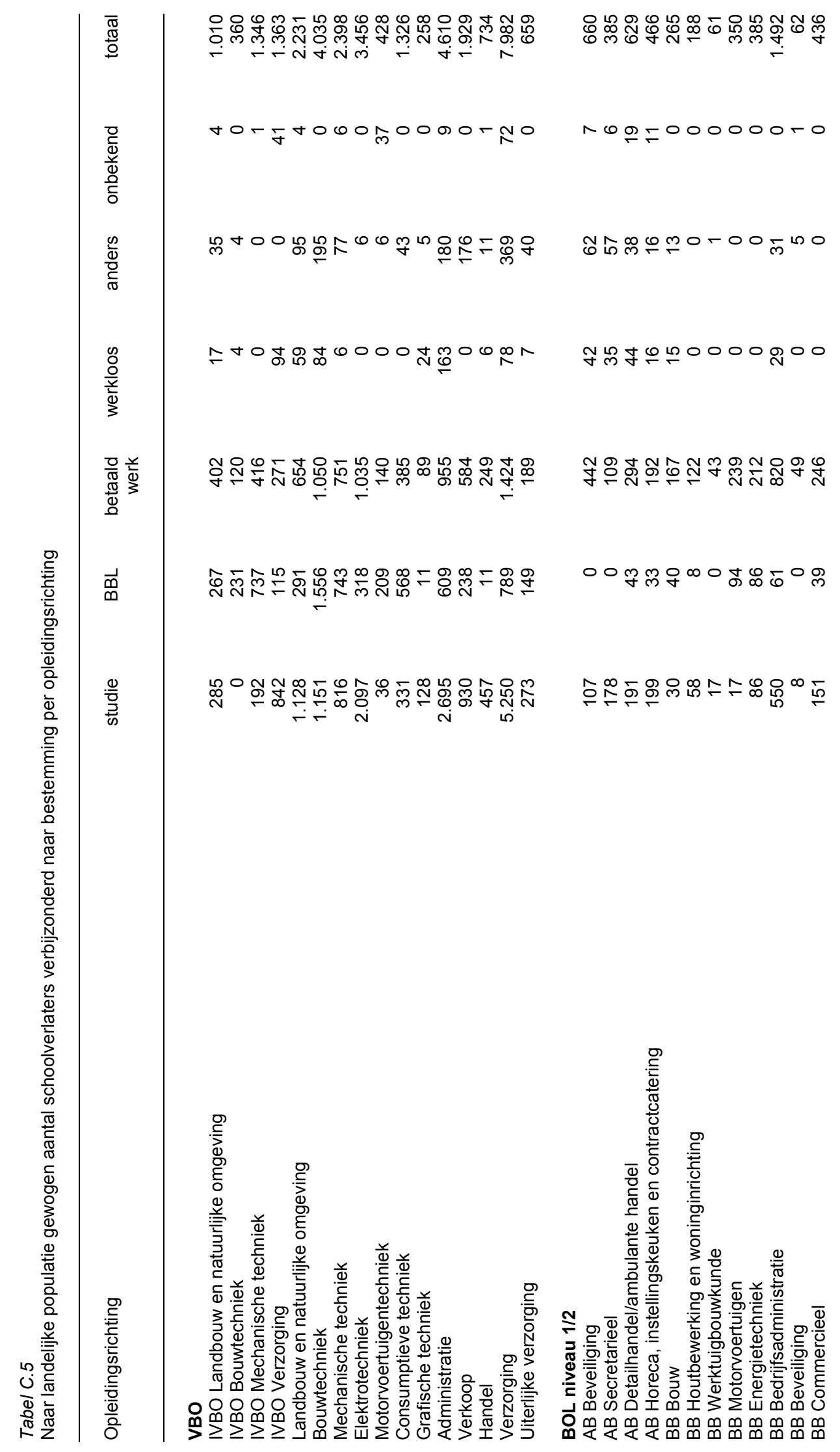




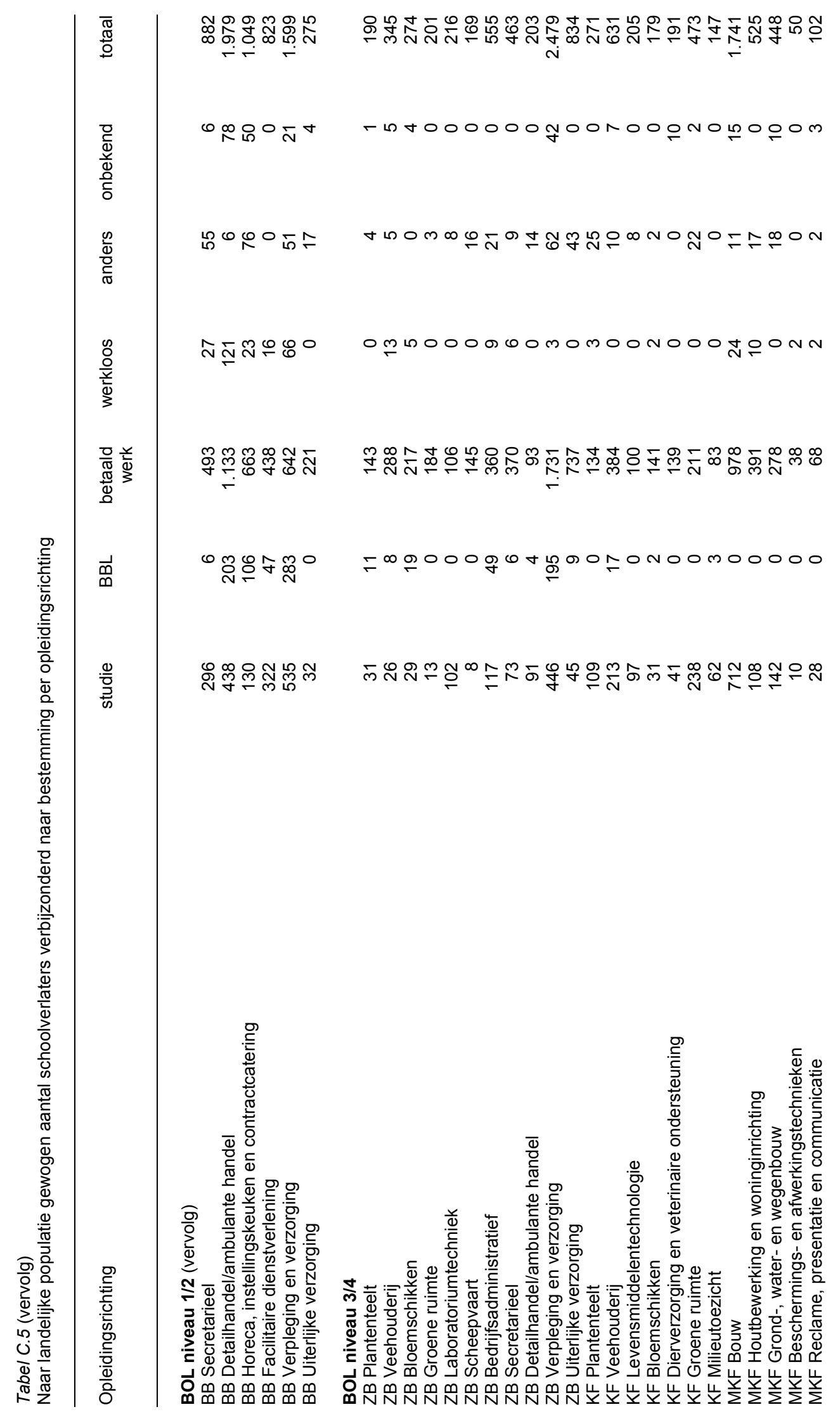




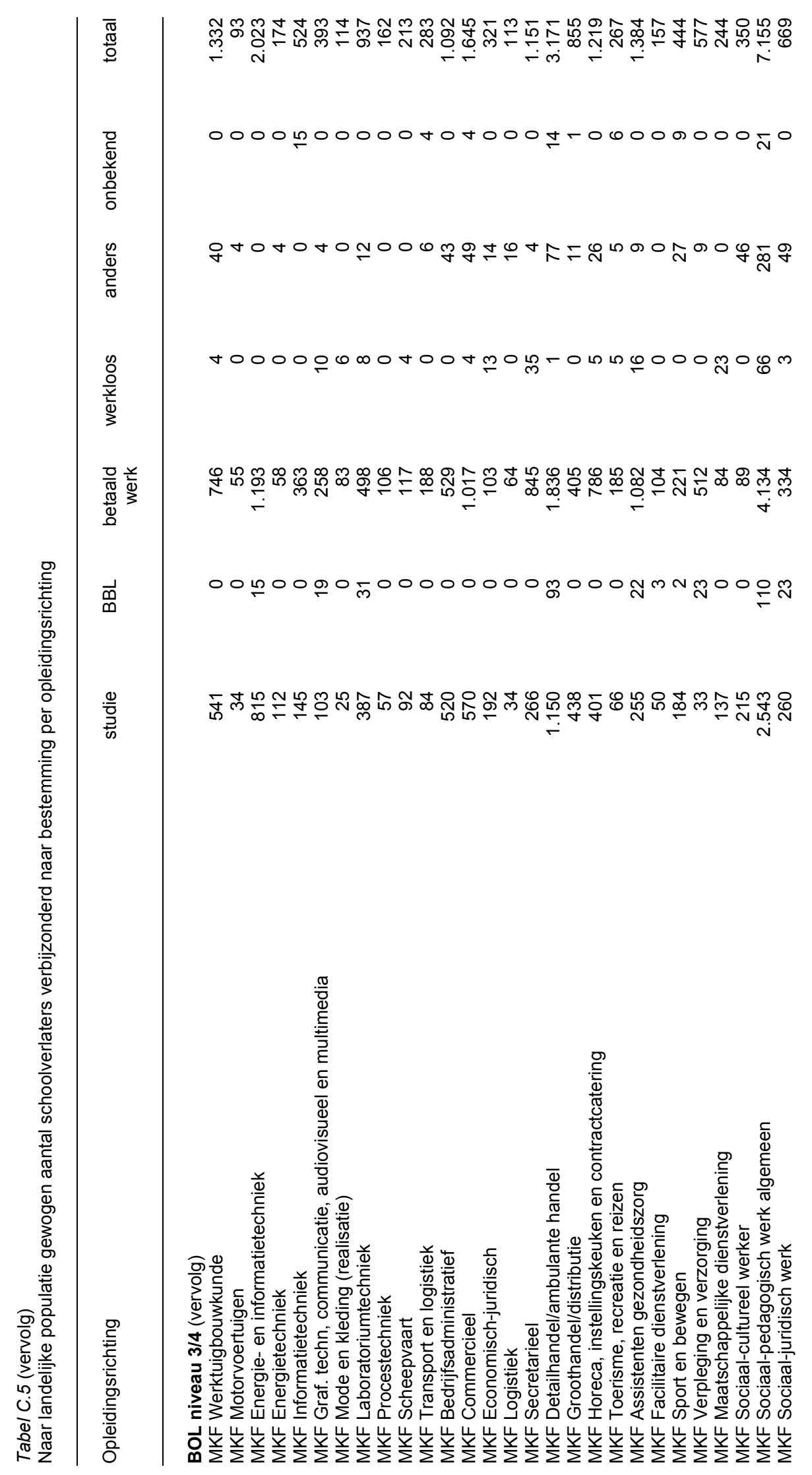




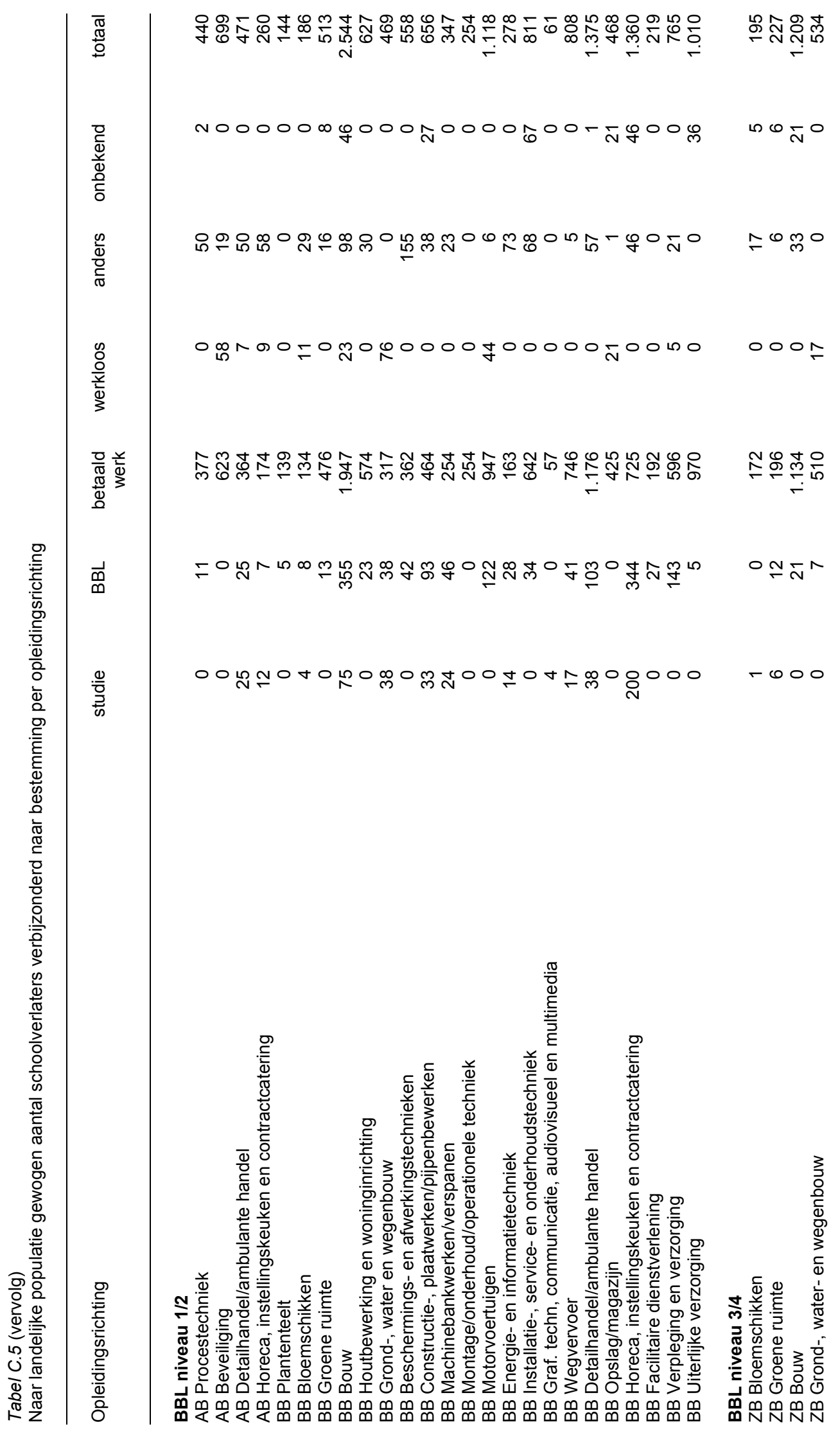




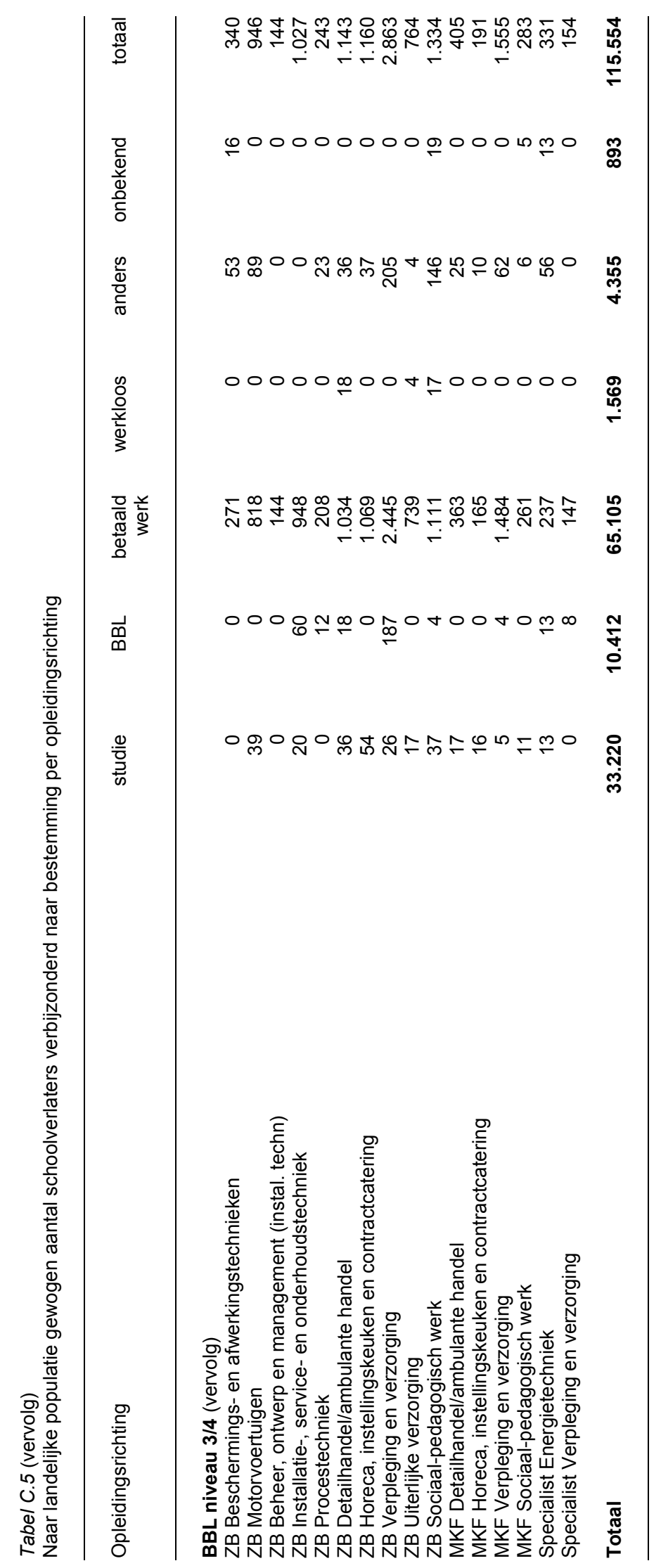


Tabel C.6

Responspercentage per opleidingsrichting

Opleidingsrichting

VBO

IVBO Landbouw en natuurlijke omgeving $\quad 34$

IVBO Techniek

IVBO Bouwtechniek

IVBO Mechanische techniek

27

IVBO Consumptieve techniek

IVBO Elektrotechniek

IVBO Administratie $\quad 50$

IVBO Verkoop $\quad 42$

IVBO Verzorging $\quad 35$

IVBO Uiterlijke verzorging $\quad 40$

IVBO Mode en kleding $\quad 17$

Landbouw en natuurlijke omgeving $\quad 42$

$\begin{array}{lr}\text { Techniek } & 100\end{array}$

$\begin{array}{ll}\text { Bouwtechniek } & 26\end{array}$

Mechanische techniek $\quad 28$

$\begin{array}{lr}\text { Elektrotechniek } & 27\end{array}$

Installatietechniek 24

Motorvoertuigentechniek $\quad 34$

Consumptieve techniek $\quad 27$

Grafische techniek $\quad 20$

$\begin{array}{lr}\text { Nautische opleidingen } & 100\end{array}$

$\begin{array}{lr}\text { Economie } & 100\end{array}$

$\begin{array}{ll}\text { Administratie } & 30\end{array}$

Verkoop $\quad 24$

Handel $\quad 26$

Gezondheidszorg $\quad 100$

Verzorging $\quad 44$

Uiterlijke verzorging $\quad 36$

$\begin{array}{lr}\text { Mode en kleding } & 50\end{array}$

VMBO Economie $\quad 100$

VMBO Economie Gem Iw handel en verkoop $\quad 100$

VMBO Zorg en Welzijn $\quad 100$

VMBO Zorg en Welzijn Gem Iw verzorging $\quad 100$

BOL niveau $1 / 2$

AB Constructie-, plaatwerken/pijpenbewerken $\quad 13$

AB Machinebankwerken/verspanen $\quad 14$

AB Motorvoertuigen $\quad 12$

$\begin{array}{ll}A B \text { Energie- en informatietechniek } & 50\end{array}$

$\begin{array}{lr}A B \text { Energietechniek } & 18\end{array}$

AB Mode en kleding $\quad 33$

AB Brood- en banketbakken $\quad 18$

$\begin{array}{lr}A B \text { Economie } & 100\end{array}$

AB Beveiliging $\quad 32$

AB Secretarieel $\quad 22$

AB Detailhandel/ambulante handel $\quad 20$

AB Horeca, instellingskeuken en contractcatering $\quad 18$

BB Plantenteelt $\quad 34$

$\begin{array}{ll}\text { BB Veehouderij } & 16\end{array}$

BB Bloemschikken 31

$\begin{array}{ll}\text { BB Dierverzorging en veterinaire ondersteuning } & 20\end{array}$

BB Paardenhouderij en paardensport 44

BB Groene ruimte $\quad 45$

BB Bouw $\quad 36$

BB Houtbewerking en woninginrichting -29

BB Beschermings- en afwerkingstechnieken 46

BB Constructie-, plaatwerken/pijpenbewerken $\quad 39$

BB Machinebankwerken/verspanen 43 
Tabel C. 6 (vervolg)

Responspercentage per opleidingsrichting

Opleidingsrichting

BOL niveau $1 / 2$ (vervolg)

BB Operationele techniek

BB Vliegtuigtechnieken

BB Werktuigbouwkunde

BB Motorvoertuigen

BB Energietechniek

BB Installatie- service- en onderhoudstechniek

BB Mode en kleding (realisatie) 10

BB Haven en vervoer $\quad 29$

BB Scheepvaart 33

BB Brood- en banketbakken algemeen $\quad 26$

BB Bedrijfsadministratie $\quad 23$

BB Beveiliging $\quad 56$

BB Commercieel $\quad 23$

BB Secretarieel $\quad 24$

BB Detailhandel/ambulante handel $\quad 20$

BB Horeca, instellingskeuken en contractcatering $\quad 30$

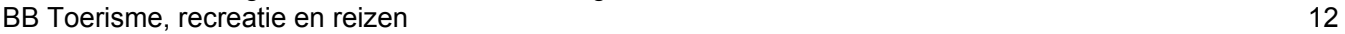

BB Facilitaire dienstverlening $\quad 33$

BB Verpleging en verzorging $\quad 32$

$\begin{array}{lr}\text { BB Uiterlijke verzorging } & 28\end{array}$

BOL niveau $3 / 4$

ZB Plantenteelt

ZB Veehouderij

ZB Levensmiddelentechnologie $\quad 50$

ZB Bloemschikken $\quad 37$

ZB Dierverzorging en veterinaire ondersteuning 45

$\begin{array}{ll}\text { ZB Paardenhouderij en paardensport } & 37\end{array}$

ZB Groene ruimte $\quad 38$

ZB Houtbewerking en woninginrichting $\quad 32$

ZB Energie- en informatietechniek $\quad 50$

$\begin{array}{ll}\text { ZB Energietechniek } & 60\end{array}$

ZB Scheepsbouwkunde $\quad 45$

ZB Laboratoriumtechniek $\quad 50$

ZB Scheepvaart $\quad 36$

ZB Economie $\quad 100$

ZB Automatisering $\quad 30$

ZB Bedrijfsadministratief $\quad 31$

ZB Commercieel

$\begin{array}{ll}\text { ZB Secretarieel } & 27\end{array}$

ZB Detailhandel/ambulante handel $\quad 17$

ZB Groothandel/distributie $\quad 40$

ZB Verpleging en verzorging $\quad 50$

ZB Uiterlijke verzorging $\quad 40$

$\begin{array}{lr}\text { ZB Sociaal pedagogisch werk } & 100\end{array}$

$\begin{array}{ll}\text { KF Plantenteelt } & 48\end{array}$

KF Veehouderij $\quad 51$

KF Levensmiddelentechnologie $\quad 57$

KF Bloemschikken $\quad 45$

$\begin{array}{ll}\text { KF Dierverzorging en veterinaire ondersteuning } & 64\end{array}$

KF Biologisch-dynamische land- en tuinbouw $\quad 5$

KF Paardenhouderij en paardensport $\quad 35$

KF Groene ruimte $\quad 43$

KF Milieutoezicht $\quad 60$

MKF Techniek $\quad 55$

$\begin{array}{ll}\text { MKF Bouw } & 43\end{array}$

MKF Houtbewerking en woninginrichting $\quad 38$

MKF Grond-, water- en wegenbouw $\quad 43$ 
Tabel C. 6 (vervolg)

Responspercentage per opleidingsrichting

Opleidingsrichting

BOL niveau 3/4 (vervolg)

MKF Beschermings- en afwerkingstechnieken $\quad 34$

MKF Reclame, presentatie en communicatie

MKF Fijnmechanische techniek $\quad 30$

MKF Meet- en regeltechniek $\quad 63$

MKF Operationele techniek $\quad 24$

MKF Vliegtuigtechnieken $\quad 36$

MKF Werktuigbouwkunde $\quad 34$

MKF Motorvoertuigen $\quad 37$

MKF Energie- en informatietechniek $\quad 31$

$\begin{array}{ll}\text { MKF Energietechniek } & 39\end{array}$

MKF Informatietechniek $\quad 28$

MKF Scheepsbouwkunde $\quad 14$

MKF Fijne techniek $\quad 32$

MKF Graf. techn, communicatie, audiovisueel en multimedia $\quad 25$

MKF Mode en kleding (realisatie)

MKF Laboratoriumtechniek $\quad 45$

MKF Milieutechniek $\quad 38$

MKF Procestechniek $\quad 45$

$\begin{array}{ll}\text { MKF Haven en vervoer } & 33\end{array}$

MKF Scheepvaart $\quad-40$

MKF Transport en logistiek $\quad 34$

$\begin{array}{ll}\text { MKF Economie } & 71\end{array}$

$\begin{array}{ll}\text { MKF Automatisering } & 29\end{array}$

MKF Bedrijfsadministratief $\quad 36$

MKF Commercieel $\quad 26$

MKF Economisch-juridisch $\quad 41$

MKF Logistiek $\quad 34$

MKF Secretarieel $\quad 43$

MKF Detailhandel/ambulante handel $\quad 32$

MKF Groothandel/distributie $\quad 30$

MKF Opslag/magazijn $\quad 36$

MKF Horeca, instellingskeuken en contractcatering $\quad 37$

MKF Toerisme, recreatie en reizen $\quad 23$

MKF Assistenten gezondheidszorg $\quad 52$

MKF Facilitaire dienstverlening $\quad 44$

$\begin{array}{ll}\text { MKF Sport en bewegen } & 51\end{array}$

$\begin{array}{ll}\text { MKF Verpleging en verzorging } & 47\end{array}$

MKF Maatschappelijke dienstverlening $\quad 52$

MKF Sociaal-cultureel werker $\quad 31$

MKF Sociaal-pedagogisch werk algemeen $\quad 44$

MKF Sociaal-juridisch werk $\quad 23$

$\begin{array}{lr}\text { Specialist Economie } & 100\end{array}$

Specialist Automatisering $\quad 32$

BBL niveau $1 / 2$

AB Industriële lakverwerking $\quad 14$

AB Constructie-, plaatwerken/pijpenbewerken $\quad 24$

AB Lassen $\quad 24$

AB Machinebankwerken/verspanen $\quad 9$

AB Montage/onderhoud/operationele techniek $\quad 50$

$\begin{array}{ll}A B \text { Carrosserie en wagenbouw } & 7\end{array}$

$\begin{array}{ll}A B \text { Motorvoertuigen } & 15\end{array}$

AB Energietechniek $\quad 25$

AB Graf. techn, communicatie, audiovisueel en multimedia $\quad 22$

AB Mode en techniek $\quad 60$

$\begin{array}{ll}A B \text { Procestechniek } & 16\end{array}$

AB Haven en vervoer $\quad 16$

AB Wegvervoer $\quad 24$

$\begin{array}{ll}\text { AB Brood- en banketbakken } & 17\end{array}$ 
Tabel C. 6 (vervolg)

Responspercentage per opleidingsrichting

Opleidingsrichting

BBL niveau $1 / 2$ (vervolg)

$A B$ Beveiliging

$A B$ Secretarieel

$A B$ Detailhandel/ambulante handel

AB Groothandel/distributie

AB Horeca, instellingskeuken en contractcatering

BB Plantenteelt

BB Veehouderij

BB Levensmiddelentechnologie

BB Bloemschikken

BB Bierverzorging en veterinaire ondersteuning

BB Biologisch-dynamische land- en tuinbouw $\quad 50$

BB Paardenhouderij en paardensport 33

BB Groene ruimte $\quad 30$

BB Techniek $\quad 50$

BB Bouw 24

BB Houtbewerking en woninginrichting $\quad 29$

BB Grond-, water en wegenbouw $\quad 14$

BB Afbouw $\quad 5$

BB Beschermings- en afwerkingstechnieken $\quad 16$

BB Industriele lakverwerking $\quad 20$

$\begin{array}{ll}\text { BB Constructie-, plaatwerken/pijpenbewerken } & 25\end{array}$

BB Landbouwmechanisatie $\quad 20$

BB Lassen $\quad 24$

$\begin{array}{ll}\text { BB Machinebankwerken/verspanen } & 36\end{array}$

BB Meet- en regeltechniek $\quad 47$

BB Montage/onderhoud/operationele techniek $\quad 19$

BB Scheepsbouw (metaal) 14

$\begin{array}{ll}\text { BB Vliegtuigtuigtechnieken } & 17\end{array}$

BB Carrosserie en wagenbouw $r$

BB Motorvoertuigen $\quad-22$

BB Energie- en informatietechniek $\quad 19$

$\begin{array}{ll}\text { BB Energietechniek } & 20\end{array}$

BB Informatietechniek $\quad 25$

BB Distributietechniek $\quad 40$

BB Installatie-, service- en onderhoudstechniek $\quad 19$

BB Koudetechniek $\quad 34$

BB Fijne techniek $\quad 29$

BB Pianotechniek $\quad 25$

BB Graf. techn, communicatie, audiovisueel en multimedia $\quad 27$

BB Procestechniek $\quad 27$

$\begin{array}{ll}\text { BB Wegvervoer } & 36\end{array}$

BB Brood- en banketbakken $\quad 24$

BB Bedrijfsadministratief $\quad 23$

BB Commercieel 11

BB Secretarieel 13

BB Detailhandel/ambulante handel $\quad 22$

BB Opslag/magazijn $\quad 19$

BB Horeca, instellingskeuken en contractcatering $\quad 21$

$\begin{array}{ll}\text { BB Facilitaire dienstverlening } & 43\end{array}$

BB Verpleging en verzorging $\quad 26$

$\begin{array}{ll}\text { BB Uiterlijke verzorging } & 28\end{array}$

BBL niveau $3 / 4$

ZB Plantenteelt

ZB Veehouderij

ZB Levensmiddelentechnologie $\quad 7$

ZB Bloemschikken

ZB Dierverzorging en veterinaire ondersteuning

ZB Paardenhouderij en paardensport 
Tabel C.6 (vervolg)

Responspercentage per opleidingsrichting

Opleidingsrichting

BBL niveau $3 / 4$ (vervolg)

ZB Groene ruimte $\quad 30$

ZB Techniek $\quad 100$

ZB Bouw $\quad 20$

ZB Houtbewerking en woninginrichting $\quad 25$

ZB Grond-, water- en wegenbouw

ZB Beschermings- en afwerkingstechnieken $\quad 28$

ZB Industriële lakverwerking $\quad 33$

ZB Constructie-, plaatwerken/pijpenbewerken $\quad 32$

37

ZB Montage/onderhoud/operationele techniek $\quad 19$

$\begin{array}{ll}\text { ZB Vliegtuigtechnieken } & 8\end{array}$

ZB Carrosserie en wagenbouw $\quad 26$

ZB Motorvoertuigen $\quad 22$

\begin{tabular}{ll} 
ZB Energie- en informatietechniek & 26 \\
\hline ZB En & 26
\end{tabular}

ZB Energietechniek $\quad 32$

$\begin{array}{ll}\text { ZB Beheer, ontwerp en management (instal. techn) } & 27\end{array}$

ZB Distributietechniek 13

ZB Installatie-, service- en onderhoudstechniek $\quad 20$

ZB Koudetechniek $\quad 32$

ZB Graf. techn, communicatie, audiovisueel en multimedia

ZB Procestechniek $\quad 39$

ZB Wegvervoer $\quad 32$

ZB Brood- en banketbakken $\quad 41$

ZB Automatisering $\quad 13$

ZB Bedrijfsadministratief $\quad 27$

ZB Commercieel $\quad 14$

ZB Logistiek $\quad 43$

ZB Secretarieel

ZB Detailhandel/ambulante handel $\quad 24$

ZB Groothandel/distributie $\quad 50$

ZB Opslag/magazijn $\quad 24$

ZB Horeca, instellingskeuken en contractcatering

ZB Gezondheidszorg $\quad 100$

ZB Verpleging en verzorging $\quad 36$

ZB Uiterlijke verzorging $\quad 32$

ZB Sociaal-pedagogisch werk $\quad 34$

$\begin{array}{ll}\text { KF Plantenteelt } & 27\end{array}$

KF Veehouderij $\quad 40$

KF Levensmiddelentechnologie $\quad 27$

KF Bloemschikken $\quad 53$

KF Dierverzorging en veterinaire ondersteuning $r$

KF Paardenhouderij en paardensport $\quad 25$

KF Groene ruimte $\quad 46$

$\begin{array}{lr}\text { MKF Techniek } & 29\end{array}$

MKF Bouw $\quad 22$

$\begin{array}{lr}\text { MKF Houtbewerking en woninginrichting } & 100\end{array}$

MKF Economie $\quad 50$

MKF Automatisering $\quad 30$

MKF Commercieel $\quad 33$

$\begin{array}{ll}\text { MKF Logistiek } & 42 \\ \text { MKF Secretariel } & 43\end{array}$

$\begin{array}{ll}\text { MKF Secretarieel } & 43\end{array}$

MKF Detailhandel/ambulante handel $\quad 32$

MKF Groothandel/distributie $\quad 33$

MKF Opslag/magazijn $\quad 25$

MKF Textielhandel $\quad 50$

MKF Horeca, instellingskeuken en contractcatering $\quad 42$

MKF Gezondheidszorg $\quad 50$

MKF Verpleging en verzorging $\quad 29$

MKF Sociaal-pedagogisch werk $\quad 46$ 
Tabel C. 6 (vervolg)

Responspercentage per opleidingsrichting

Opleidingsrichting

BBL niveau 3/4 (vervolg)

Specialist Techniek

Specialist Bouw

100

Specialist Beschermings- en afwerkingstechnieken

100

Specialist Werkvoorbereiden

Specialist Motorvoertuigen

Specialist Energie- en informatietechniek $\quad 35$

$\begin{array}{ll}\text { Specialist Energietechniek } & 29\end{array}$

Specialist Installatie-, service- en onderhoudstechniek $\quad 40$

Specialist Graf. techn, communicatie, audiovisueel en mu $\quad 22$

Specialist Procestechniek $\quad 32$

$\begin{array}{ll}\text { Specialist Brood- en banketbakken } & 57\end{array}$

Specialist Automatisering $\quad 31$

$\begin{array}{lr}\text { Specialist Horeca, instellingskeuken en contractcatering } & 100\end{array}$

Specialist Verpleging en verzorging $\quad 45$

In-service Z-verpleegkundige $\quad 100$

$\begin{array}{ll}\text { Totaal } & 33\end{array}$ 

D. Opleidingsindeling 



\title{
Overzicht van opleidingen per opleidingssector
}

\author{
MAVO \\ MAVO \\ HAVO \\ HAVO/HAVO-MBO/VHBO \\ VWO \\ VWO \\ IVBO \\ IVBO Landbouw en natuurlijke omgeving \\ IVBO Techniek \\ IVBO Bouwtechniek \\ IVBO Mechanische techniek \\ IVBO Consumptieve techniek \\ IVBO Elektrotechniek \\ IVBO Economie \\ IVBO Administratie \\ IVBO Verkoop \\ IVBO Gezondheidszorg \\ IVBO Verzorging \\ IVBO Uiterlijke verzorging \\ IVBO Mode en kleding \\ VBO landbouw \\ VBO Landbouw en natuurlijke omgeving \\ VBO techniek \\ VBO Techniek \\ VBO Bouwtechniek \\ VBO Mechanische techniek \\ VBO Elektrotechniek \\ VBO Installatietechniek \\ VBO Motorvoertuigentechniek \\ VBO Consumptieve techniek \\ VBO Grafische techniek \\ VBO Nautische opleidingen \\ VMBO Techniek KB metaaltechniek \\ VMBO Techniek KB electrotechniek \\ VMBO Techniek BB voertuigentechniek \\ VMBO Techniek BB installatietechniek \\ VBO economie \\ VBO Economie \\ VBO Administratie \\ VBO Verkoop \\ VBO Hande \\ VMBO Economie \\ VMBO Economie Gem Iw handel en verkoop \\ VMBO Economie KB administratie \\ VMBO Economie BB administratie \\ VBO gezondheidszorg \\ VBO Gezondheidszorg \\ VBO Verzorging \\ VBO Uiterlijke verzorging \\ VBO Mode en kleding \\ VMBO Zorg en Welzijn \\ VMBO Zorg en Welzijn Gem Iw verzorging \\ $B O L$ niveau $1 / 2$ landbouw \\ BOL BB Plantenteelt \\ BOL BB Veehouderij \\ BOL BB Bloemschikken
}


BOL BB Dierverzorging en veterinaire ondersteuning BOL BB Paardenhouderij en paardensport

BOL BB Groene ruimte

BOL niveau 1/2 techniek

BOL AB Techniek

BOL AB Constructie-, plaatwerken/pijpenbewerken

BOL AB Machinebankwerken/verspanen

BOL AB Motorvoertuigen

$B O L A B$ Energie- en informatietechniek

$B O L A B$ Energietechniek

BOL AB Installatie-, service- en onderhoudstechniek

BOL AB Mode en kleding

BOL AB Brood- en banketbakken

BOL BB Techniek

BOL BB Bouw

BOL BB Houtbewerking en woninginrichting

BOL BB Beschermings- en afwerkingstechnieken

BOL BB Constructie-, plaatwerken/pijpenbewerken

BOL BB Machinebankwerken/verspanen

BOL BB Meet- en regeltechniek

BOL BB Operationele techniek

BOL BB Vliegtuigtechnieken

BOL BB Werktuigbouwkunde

BOL BB Motorvoertuigen

BOL BB Energie- en informatietechniek

BOL BB Energietechniek

BOL BB Installatie-, service- en onderhoudstechniek

BOL BB Mode en kleding (realisatie)

BOL BB Procestechniek

BOL BB Haven en vervoer

BOL BB Scheepvaart

BOL BB Transport en logistiek

BOL BB Brood- en banketbakken algemeen

$B O L$ niveau $1 / 2$ economie

BOL AB Economie

$B O L A B$ Beveiliging

BOL AB Secretarieel

BOL AB Detailhandel/ambulante handel

$\mathrm{BOL} A B$ Horeca, instellingskeuken en contractcatering

BOL BB Economie

BOL BB Bedrijfsadministratie

BOL BB Beveiliging

BOL BB Commercieel

BOL BB Secretarieel

BOL BB Detailhandel/ambulante handel

BOL BB Horeca, instellingskeuken en contractcatering

BOL BB Toerisme, recreatie en reizen

$B O L$ niveau $1 / 2$ gezondheidszorg

BOL BB Gezondheidszorg

BOL BB Facilitaire dienstverlening

BOL BB Verpleging en verzorging

BOL BB Uiterlijke verzorging

BOL niveau 3/4 landbouw

BOL ZB Plantenteelt

BOL ZB Veehouderij

BOL ZB Levensmiddelentechnologie

BOL ZB Bloemschikken

$\mathrm{BOL} Z \mathrm{ZB}$ Dierverzorging en veterinaire ondersteuning

BOL ZB Paardenhouderij en paardensport

BOL ZB Groene ruimte

BOL KF Plantenteelt

BOL KF Veehouderij

BOL KF Levensmiddelentechnologie 
BOL KF Bloemschikken

BOL KF Dierverzorging en veterinaire ondersteuning

BOL KF Biologisch-dynamische land- en tuinbouw

BOL KF Paardenhouderij en paardensport

BOL KF Groene ruimte

BOL KF Milieutoezicht

BOL niveau 3/4 techniek

BOL ZB Techniek

BOL ZB Houtbewerking en woninginrichting

BOL ZB Grond-, water- en wegenbouw

BOL ZB Werktuigbouwkunde

BOL ZB Energie- en informatietechniek

BOL ZB Energietechniek

BOL ZB Informatietechniek

BOL ZB Scheepsbouwkunde

BOL ZB Installatie-, service- en onderhoudstechniek

BOL ZB Fijne techniek

BOL ZB Mode en kleding

BOL ZB Laboratoriumtechniek

BOL ZB Scheepvaart

BOL ZB Brood- en banketbakken

BOL MKF Techniek

BOL MKF Bouw

BOL MKF Houtbewerking en woninginrichting

BOL MKF Grond-, water- en wegenbouw

BOL MKF Beschermings- en afwerkingstechnieken

BOL MKF Reclame, presentatie en communicatie

BOL MKF Instrumenttechniek

BOL MKF Fijnmechanische techniek

BOL MKF Lassen

BOL MKF Meet- en regeltechniek

BOL MKF Operationele techniek

BOL MKF Vliegtuigtechnieken

BOL MKF Werktuigbouwkunde

BOL MKF Motorvoertuigen

BOL MKF Motorvoertuigen en carrosserietechniek

BOL MKF Energie- en informatietechniek

BOL MKF Energietechniek

BOL MKF Informatietechniek

BOL MKF Scheepsbouwkunde

BOL MKF Fijne techniek

BOL MKF Graf. techn, communicatie, audiovisueel en multimedia

BOL MKF Mode en kleding (realisatie)

BOL MKF Laboratoriumtechniek

BOL MKF Milieutechniek

BOL MKF Procestechniek

BOL MKF Haven en vervoer

BOL MKF Scheepvaart

BOL MKF Transport en logistiek

BOL MKF Wegvervoer

BOL Specialist Energie- en informatietechniek

$B O L$ niveau $3 / 4$ economie

BOL ZB Economie

BOL ZB Automatisering

BOL ZB Bedrijfsadministratief

BOL ZB Commerciee

BOL ZB Secretarieel

BOL ZB Detailhandel/ambulante handel

BOL ZB Groothandel/distributie

BOL MKF Economie

BOL MKF Automatisering

BOL MKF Bedrijfsadministratief

BOL MKF Commercieel

BOL MKF Economisch-juridisch

BOL MKF Logistiek 
BOL MKF Secretarieel

BOL MKF Administratie - vrije richting

BOL MKF Detailhandel/ambulante handel

BOL MKF Groothandel/distributie

BOL MKF Opslag/magazijn

BOL MKF Horeca, instellingskeuken en contractcatering

BOL MKF Toerisme, recreatie en reizen

BOL Specialist Economie

BOL Specialist Automatisering

$B O L$ niveau $3 / 4$ gezondheidszorg

BOL ZB Gezondheidszorg

$B O L$ ZB Verpleging en verzorging

BOL ZB Uiterlijke verzorging

BOL MKF Gezondheidszorg

BOL MKF Assistenten gezondheidszorg

BOL MKF Facilitaire dienstverlening

BOL MKF Sport en bewegen

BOL MKF Verpleging en verzorging

$B O L$ niveau $3 / 4$ gedrag en maatschappij

BOL ZB Sociaal pedagogisch werk

BOL MKF Maatschappelijke dienstverlening

BOL MKF Sociaal-cultureel werker

BOL MKF Sociaal-pedagogisch werk algemeen

BOL MKF Sociaal-juridisch werk

BBL niveau 1/2 landbouw

BBL BB Plantenteelt

BBL BB Veehouderij

BBL BB Levensmiddelentechnologie

BBL BB Bloemschikken

BBL BB Dierverzorging en veterinaire ondersteuning

BBL BB Biologisch-dynamische land- en tuinbouw

BBL BB Paardenhouderij en paardensport

BBL BB Groene ruimte

BBL niveau 1/2 techniek

BBL AB Techniek

$B B L A B$ Industriële lakverwerking

BBL AB Constructie-, plaatwerken/pijpenbewerken

BBL AB Lassen

BBL AB Machinebankwerken/verspanen

BBL AB Montage/onderhoud/operationele techniek

$B B L A B$ Carrosserie en wagenbouw

BBL AB Motorvoertuigen

BBL AB Energietechniek

BBL AB Installatie-, service- en onderhoudstechniek

BBL AB Graf. techn, communicatie, audiovisueel en multimedia

BBL AB Mode en techniek

BBL AB Procestechniek

$B B L A B$ Haven en vervoer

BBL AB Wegvervoer

BBL AB Brood- en banketbakken

BBL BB Techniek

BBL BB Bouw

BBL BB Houtbewerking en woninginrichting

BBL BB Grond-, water en wegenbouw

BBL BB Afbouw

BBL BB Beschermings- en afwerkingstechnieken

BBL BB Industriele lakverwerking

BBL BB Constructie-, plaatwerken/pijpenbewerken

BBL BB Landbouwmechanisatie

BBL BB Lassen

BBL BB Machinebankwerken/verspanen

BBL BB Meet- en regeltechniek

BBL BB Montage/onderhoud/operationele techniek 
BBL BB Scheepsbouw (metaal)

BBL BB Vliegtuigtuigtechnieken

BBL BB Carrosserie en wagenbouw

BBL BB Motorvoertuigen

BBL BB Energie- en informatietechniek

BBL BB Energietechniek

BBL BB Informatietechniek

BBL BB Distributietechniek

BBL BB Installatie-, service- en onderhoudstechniek

BBL BB Koudetechniek

BBL BB Fijne techniek

BBL BB Pianotechniek

BBL BB Graf. techn, communicatie, audiovisueel en multimedia

BBL BB Procestechniek

BBL BB Haven en vervoer

BBL BB Wegvervoer

BBL BB Brood- en banketbakken

$B B L$ niveau 1/2 economie

BBL AB Economie

$B B L A B$ Beveiliging

BBL AB Secretarieel

BBL AB Detailhandel/ambulante handel

BBL AB Groothandel/distributie

$B B L A B$ Horeca, instellingskeuken en contractcatering

BBL BB Bedrijfsadministratief

BBL BB Beveiliging

BBL BB Commerciee

BBL BB Secretarieel

BBL BB Detailhandel/ambulante handel

BBL BB Opslag/magazijn

BBL BB Horeca, instellingskeuken en contractcatering

BBL niveau 1/2 gezondheidszorg

BBL BB Gezondheidszorg

BBL BB Facilitaire dienstverlening

BBL BB Verpleging en verzorging

BBL BB Uiterlijke verzorging

$B B L$ niveau 3/4 landbouw

BBL ZB Plantenteelt

BBL ZB Veehouderij

BBL ZB Levensmiddelentechnologie

BBL ZB Bloemschikken

$B B L Z B$ Dierverzorging en veterinaire ondersteuning

BBL ZB Paardenhouderij en paardensport

BBL ZB Groene ruimte

BBL KF Plantenteelt

BBL KF Veehouderij

BBL KF Levensmiddelentechnologie

BBL KF Bloemschikken

BBL KF Dierverzorging en veterinaire ondersteuning

BBL KF Paardenhouderij en paardensport

BBL KF Groene ruimte

BBL niveau 3/4 techniek

BBL ZB Techniek

BBL ZB Bouw

$B B L$ ZB Houtbewerking en woninginrichting

BBL ZB Grond-, water- en wegenbouw

BBL ZB Afbouw

BBL ZB Beschermings- en afwerkingstechnieken

BBL ZB Industriële lakverwerking

BBL ZB Constructie-, plaatwerken/pijpenbewerken

BBL ZB Machinebankwerken/verspanen

BBL ZB Montage/onderhoud/operationele techniek

BBL ZB Scheepsbouwer 
BBL ZB Vliegtuigtechnieken

BBL ZB Carrosserie en wagenbouw

BBL ZB Motorvoertuigen

BBL ZB Energie- en informatietechniek

BBL ZB Energietechniek

BBL ZB Beheer, ontwerp en management (instal. techn)

BBL ZB Distributietechniek

BBL ZB Installatie-, service- en onderhoudstechniek

BBL ZB Koudetechniek

BBL ZB Graf. techn, communicatie, audiovisueel en multimedia

BBL ZB Procestechniek

BBL ZB Scheepvaart

BBL ZB Wegvervoer

BBL ZB Brood- en banketbakken

BBL MKF Techniek

BBL MKF Bouw

BBL MKF Houtbewerking en woninginrichting

BBL MKF Transport en logistiek

BBL Specialist Techniek

BBL Specialist Bouw

BBL Specialist Beschermings- en afwerkingstechnieken

BBL Specialist Werkvoorbereiden

BBL Specialist Motorvoertuigen

BBL Specialist Energie- en informatietechniek

BBL Specialist Energietechniek

BBL Specialist Installatie-, service- en onderhoudstechniek

BBL Specialist Graf. techn, communicatie, audiovisueel en mu

BBL Specialist Procestechniek

BBL Specialist Brood- en banketbakken

$B B L$ niveau 3/4 economie

BBL ZB Economie

BBL ZB Automatisering

BBL ZB Bedrijfsadministratief

BBL ZB Commercieel

BBL ZB Logistiek

BBL ZB Secretarieel

BBL ZB Detailhandel/ambulante handel

BBL ZB Groothandel/distributie

BBL ZB Opslag/magazijn

BBL ZB Horeca, instellingskeuken en contractcatering

BBL ZB Toerisme, recreatie en reizen

BBL MKF Economie

BBL MKF Automatisering

BBL MKF Commercieel

BBL MKF Logistiek

BBL MKF Secretarieel

BBL MKF Detailhandel/ambulante handel

BBL MKF Groothandel/distributie

BBL MKF Opslag/magazijn

BBL MKF Textielhandel

BBL MKF Horeca, instellingskeuken en contractcatering

BBL Specialist Automatisering

BBL Specialist Horeca, instellingskeuken en contractcatering

$B B L$ niveau 3/4 gezondheidszorg

BBL ZB Gezondheidszorg

$B B L$ ZB Verpleging en verzorging

BBL ZB Uiterlijke verzorging

BBL MKF Gezondheidszorg

BBL MKF Verpleging en verzorging

BBL MKF Zorg en welzijn

BBL Specialist Verpleging en verzorging

In-service

In-service Verpleegkundige A

In-service Z-verpleegkundige 
BBL niveau $3 / 4$ gedrag en maatschappij

BBL ZB Sociaal-pedagogisch werk

BBL MKF Sociaal-pedagogisch werk

HBO landbouw

HBO Landbouw

HBO Landbouw/produktie

HBO Landbouw/bedrijfskunde

HBO Milieu/groene ruimte

HBO Technologie/laboratorium

HBO Agrarische docentopl.

HBO Agrarische bedrijfskunde

HBO Plattelandsvernieuwing

HBO onderwijs

HBO Leraar basis-/speciaalonderwijs

HBO Leraar VO taal 1-vak (2e gr.)

HBO Leraar VO maatschappij 1-vak (2e gr.)

HBO Leraar VO expressie 1-vak (2e gr.)

HBO Leraar techniek VO 1-vak (2e gr.)

HBO Leraar VO maatschappij (1e gr.)

HBO Leraar VO lichamelijke oefening (1e gr.)

HBO Leraar VO exact 1-vak (1e/2e gr.)

HBO Algemene beroepenvariant Pedagogiek

HBO techniek

HBO Kort Logistiek

HBO Kort Bedrijfskaderopleiding

HBO Bouwkunde

HBO Civiele techniek

HBO Geodesie

HBO Verkeerskunde

HBO Ruimtelijke ordening en planologie

HBO Milieukunde (technisch)

HBO Logistiek en technische vervoerskunde

HBO Elektrotechniek

HBO Computertechniek

HBO Hogere informatica

HBO Informatica en informatiekunde

HBO Werktuigbouwkunde

HBO Autotechniek

HBO Luchtvaarttechnologie

HBO Scheepsbouwkunde

HBO Technische natuurkunde

HBO Industrieel product ontwerpen

HBO Chemische technologie

HBO Aquatische ecotechnologie

HBO Milieugerichte materiaaltechnologie

HBO Milieutechnologie (technische)

HBO Wiskunde

HBO Biologie en medisch laboratoriumonderzoek

HBO Chemie

HBO Technisch-commerciele confectiekunde

HBO Technische bedrijfskunde

HBO Bouwtechnische bedrijfskunde

HBO Mode-, textielvormgeving en styling

HBO Visual marketing in fashion

HBO Algemene operationele technologie

HBO Petroleum- en gastechnologie

HBO Hydrografie

HBO Maritiem officier

HBO Vliegtuigoperatie

HBO Analytische proces- en laboratoriuminstrumentatie

HBO Biologische laboratoriumopleiding

HBO Chemische laboratoriumopleiding

HBO Medische laboratoriumopleiding

HBO Laboratoriuminformatica en automatisering 


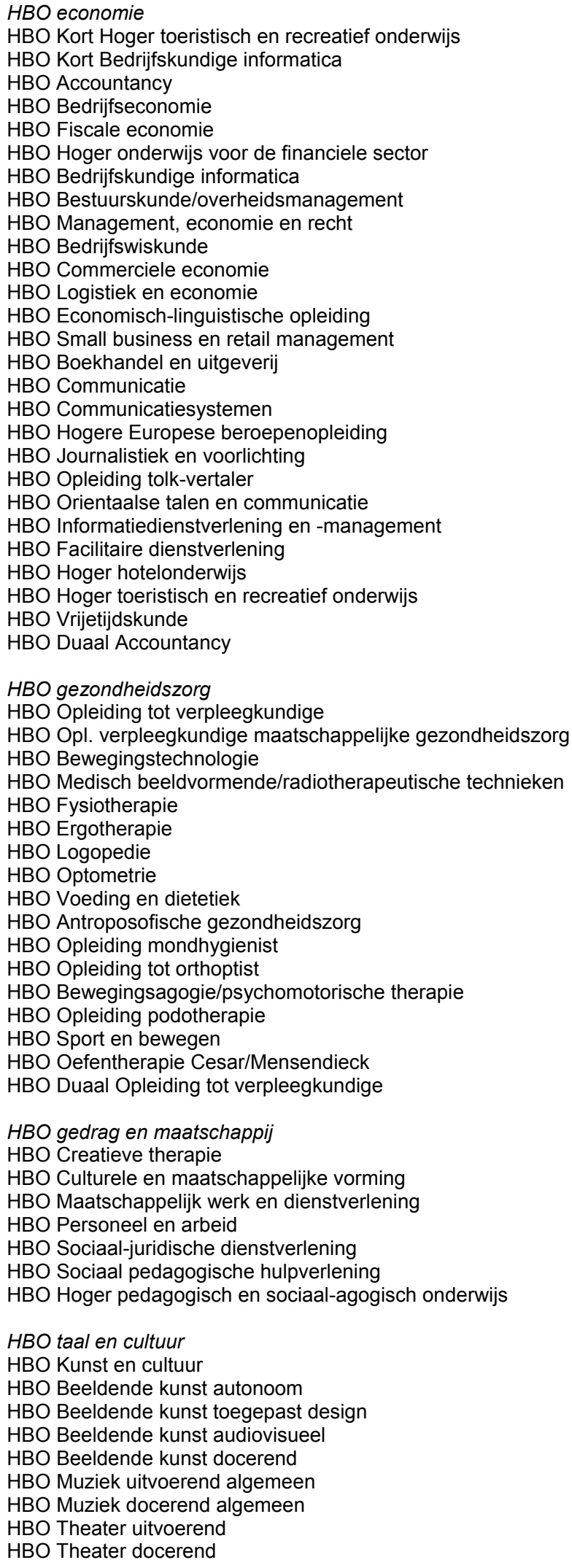


WO landbouw

WO Bos- en natuurbeheer

WO Landinrichtingswetenschappen

WO Tropisch landgebruik

WO Plantenteeltwetenschappen

WO Plantenveredeling en gewasbescherming

WO Zootechniek

WO Bioprocestechnologie

WO Levensmiddelentechnologie

WO Landbouwtechniek

WO Economie van landbouw en milieu

WO Voeding en gezondheid

WO Rurale ontwikkelingsstudies

WO Huishoud- en consumentenwetenschappen

WO Agrosysteemkunde

WO Bodem, water en atmosfeer

WO Biologie

WO Milieuhygiene

WO Moleculaire wetenschappen

WO onderwijs

WO Kort Univ. leraaropl. Duits

WO Kort Univ. leraaropl. Engels

WO Kort Univ. leraaropl. Frans

WO Kort Univ. leraaropl. Grieks en Latijn (Klassieken)

WO Kort Univ. leraaropl. kunstgeschiedenis

WO Kort Univ. leraaropl. muziek

WO Kort Univ. leraaropl. Nederlands

WO Kort Univ. leraaropl. Spaans

WO Kort Univ. leraaropl. Arabisch

WO Kort Univ. leraaropl. aardrijkskunde

WO Kort Univ. leraaropl. algemene economie

WO Kort Univ. leraaropl. bedrijfseconomie

WO Kort Univ. leraaropl. geschiedenis en staatsinrichting

WO Kort Univ. leraaropl. maatschappijleer

WO Kort Univ. leraaropl. biologie

WO Kort Univ. leraaropl. natuurkunde

WO Kort Univ. leraaropl. scheikunde

WO Kort Univ. leraaropl. wiskunde

WO techniek

WO Technische aardwetenschappen

WO Scheikundige technologie en bioprocestechnologie

WO Technische mechanica

WO Technische natuurkunde

WO Technische scheikunde

WO Technische wiskunde

WO Bedrijfsinformatietechnologie

WO Informatietechniek

WO Technische informatica

WO Elektrotechniek

WO Bouwkunde

WO Civiele techniek

WO Civiele technologie en management

WO Geodesie

WO Installatietechniek

WO Industrieel ontwerpen

WO Luchtvaart- en ruimtevaarttechniek

WO Maritieme techniek

WO Materiaalkunde

WO Werktuigbouwkunde

WO Werktuigkundige medische technologie

WO Technische bedrijfskunde

WO Technische bestuurskunde

WO Techniek en maatschappij

WO Wijsbegeerte, wetenschap, technologie en samenleving

WO Informatica 


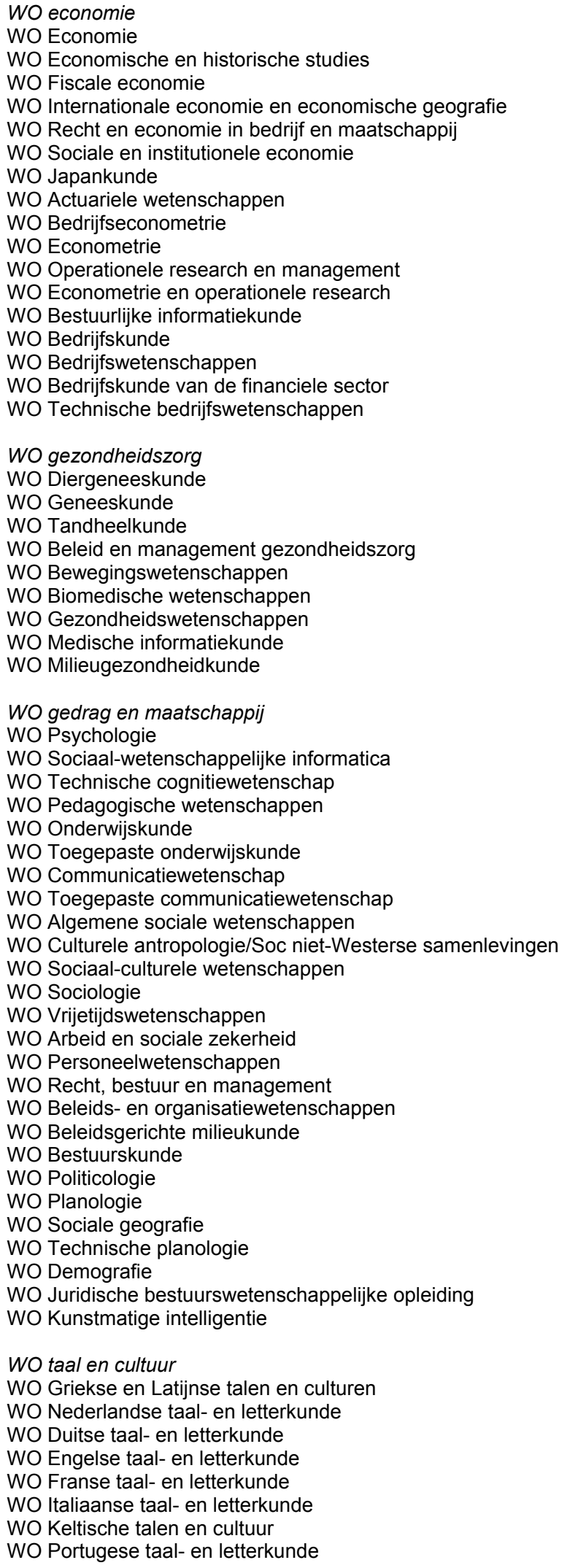

WO taal en cultuur

WO Griekse en Latijnse talen en culturen

WO Nederlandse taal- en letterkunde

WO Duitse taal- en letterkunde

WO Engelse taal- en letterkunde

WO Franse taal- en letterkunde

WO Italiaanse taal- en letterkunde

WO Keltische talen en cultuur

WO Portugese taal- en letterkunde 
WO Romaanse talen en culturen

WO Scandinavische talen en hun letterkunde

WO Spaanse taal- en letterkunde

WO Talen en culturen van Latijns Amerika

WO Arabische, Nieuwperzische en Turkse talen en culturen

WO Chinese talen en culturen

WO Indische en Iraanse talen en culturen

WO Japanse taal en cultuur

WO Nieuwgriekse taal- en letterkunde

WO Semitische talen en culturen

WO Slavische talen en hun letterkunde

WO Talen en culturen van Indiaans Amerika

WO Alfa-informatica

WO Algemene letteren

WO Algemene literatuurwetenschap

WO Algemene taalwetenschap

WO Letteren

WO Lexicologie

WO Spraak- en taalpathologie

WO Taal, spraak en informatica

WO Vertaalwetenschap

WO Toegepaste taalwetenschap

WO Afrikanistiek

WO Amerikanistiek

WO Duitslandstudies

WO Dutch studies

WO Europese studies

WO Midden-Oosten studies

WO Oost-europese studies

WO Ruslandkunde

WO Bedrijfscommunicatie letteren

WO Boek- en informatiewetenschap

WO Communicatiekunde

WO Taal, informatie en communicatie

WO Beleid en bestuur internationale organisaties

WO Culturele studies

WO Cultuur- en wetenschapsstudies

WO Film- en televisiewetenschappen

WO Kunst- en cultuurwetenschappen

WO Muziekwetenschap

WO Taal- en cultuurstudies

WO Theater-, film- en televisiewetenschappen

WO Vergelijkende kunstwetenschap: woord en beeld

WO Algemene opleiding godgeleerdheid

WO Godgeleerdheid

WO Godsdienstwetenschappen

WO Islamologie/Islamkunde

WO Levensbeschouwingen

WO Religie en levensbeschouwing

WO Religiestudies

WO Sociaal-wetenschappelijke studie van de godsdienst

WO Archeologie

WO Europese archeologie

WO Comm. en informatiewetenschappen

WO Geschiedenis

WO Kunstgeschiedenis en archeologie

WO Maatschappijgeschiedenis

WO Medievistiek

WO Wijsbegeerte

WO Wijsbegeerte op basis niet wijsgerige propedeuse

WO Wijsbegeerte van een bepaald wetenschapsgebied

WO recht en openbare orde

WO Nederlands recht

WO Nederlands recht, internationale/Europees rechtelijke opl

WO Notariele opleiding

WO Fiscaal-juridische opleiding 
WO European Law school

WO Europees-juridische opleiding

WO Internationaal recht

WO Internationaal-juridische opleiding

WO Juridische bestuurswetenschappelijke opleiding

WO Juridisch-politiekwetenschappelijke opleiding

WO Internationaal en Europees recht

WO Fiscaal recht

WO natuurwetenschappen

WO Medische biologie

WO Bedrijfs- en industriele statistiek

WO Wiskunde

WO Bedrijfsinformatiesystemen

WO Bedrijfswiskunde en informatica

WO Cognitieve kunstmatige intelligentie

WO Kennistechnologie

WO Kunstmatige intelligentie

WO Technische informatica

WO Infortmatiekunde

WO Natuurkunde

WO Sterrrenkunde

WO Geochemie

WO Geofysica

WO Geologie

WO Meteorologie en fysische oceanografie

WO Fysische geografie

WO Scheikunde

WO Biofarmaceutische wetenschappen

WO Farmacie

WO Farmacochemie

WO Biologie

WO Fundamentele biomedische wetenschappen

WO Milieubiologie

WO Milieukunde

WO Natuurwetenschappelijke milieukunde

WO Milieuwetenschappen/scheikunde

WO Milieuwetenschappen/aardwetenschappen

WO Milieuwetenschappen/biologie

WO Milieuwetenschappen/natuurkunde

WO Natuurwetenschappen

WO Wetenschapsdynamica 